\title{
Radionuclides in the Arctic Seas from the Former Soviet Union: Potential Health and Ecological Risks
}

D. Layton, R. Edson, M. Varela and B. Napier

\section{November 1, 1997}

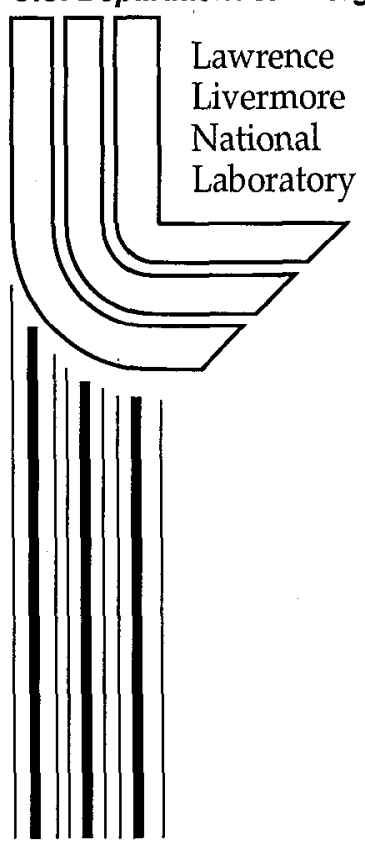





\section{DISCLAIMER}

This document was prepared as an account of work sponsored by an agency of the United States Government. Neither the United States Government nor the University of California nor any of their employees, makes any warranty, express or implied, or assumes any legal liability or responsibility for the accuracy, completeness, or usefulness of any information, apparatus, product, or process disclosed, or represents that its use would not infringe privately owned rights. Reference herein to any specific commercial product, process, or service by trade name, trademark, manufacturer, or otherwise, does not necessarily constitute or imply its endorsement, recommendation, or favoring by the United States Government or the University of California. The views and opinions of authors expressed herein do not necessarily state or reflect those of the United States Government or the University of California, and shall not be used for advertising or product endorsement purposes.

Work performed under the auspices of the U.S. Department of Energy by the University of California Lawrence Livermore National Laboratory under Contract W-7405-Eng-48.

This report has been reproduced directly from the best available copy.

Available to DOE and DOE contractors from the

Office of Scientific and Technical Information

P.O. Box 62, Oak Ridge, TN 37831

Prices available from (423) 576-8401

http:/ /apollo.osti.gov/bridge/

Available to the public from the National Technical Information Service

U.S. Department of Commerce 5285 Port Royal Rd., Springfield, VA 22161 http://www.ntis.gov/

\section{OR}

Lawrence Livermore National Laboratory Technical Information Department's Digital Library http://www.llnl.gov/tid/Library.html 


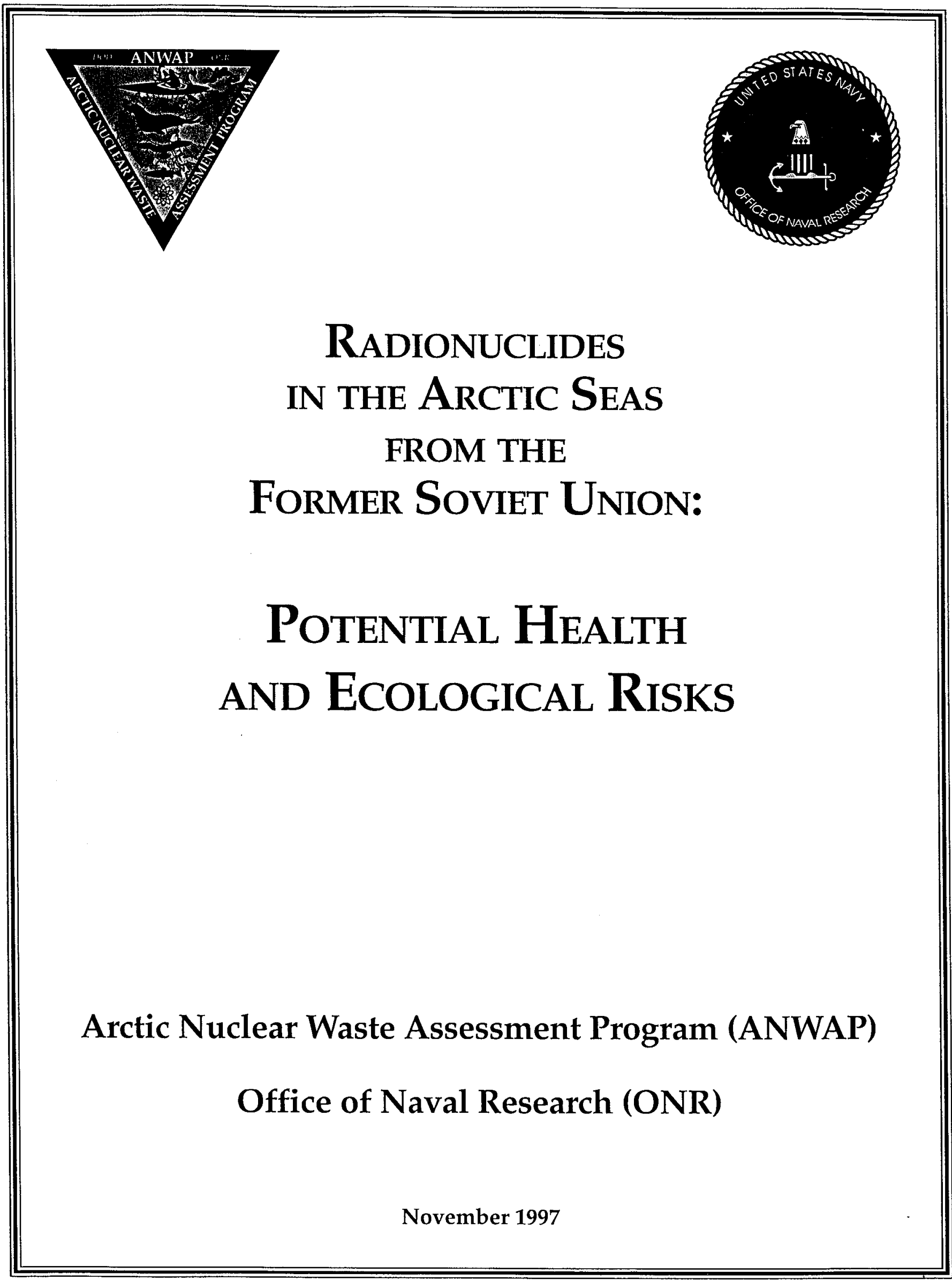





\title{
Radionuclides in the Arctic Seas FROM THE FormER SOVIET UNION: Potential Health AND ECOLOGICAL RISKS
}

\author{
Editors: \\ David Layton \\ Lawrence Livermore National Laboratory \\ Livermore, CA \\ LCDR Robert Edson \\ Marilyn Varela \\ Office of Naval Research \\ Arlington, VA \\ Bruce Napier \\ Battelle Pacific Northwest Laboratories \\ Richland, WA
}

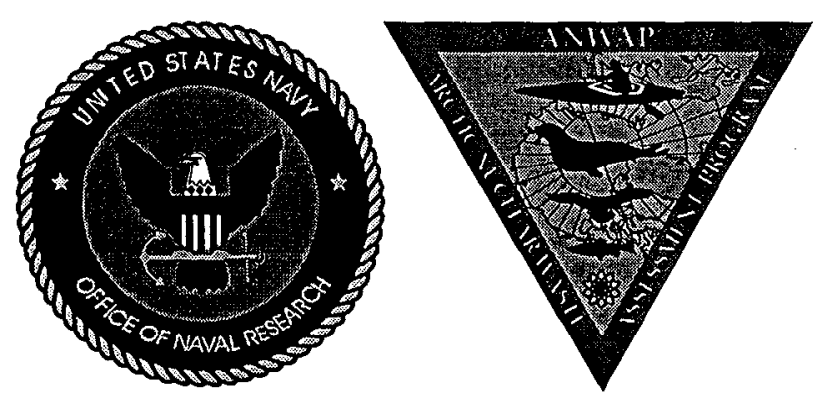

Arctic Nuclear Waste Assessment Program (ANWAP) Office of Naval Research (ONR)

November 1997 



\section{Preface}

I n 1993, radioactive waste-management practices of the former Soviet Union (FSU) came under increasing international scrutiny after Russian scientists disclosed dumped-nuclear-waste. sites in the Kara and Barents seas that contravened the London Convention ban on radioactive waste disposal at sea. The U.S. response was to fund the Office of Naval Research Arctic Nuclear Waste Assessment Program (ANWAP) to (1) quantify the types, amounts, and rates of release of radionuclides from marine disposal sites and Russian riverine sources leading to Arctic waters; (2) evaluate the transport pathways and ultimate fate of the radionuclide contaminants; and (3) identify any long-term monitoring strategies as needed. ANWAP began funding basic physical, geochemical, and biological oceanographic research in the Arctic in 1993.

By early 1995 the second year of ANWAP research was well under way and planning for the final ANWAP funding cycle emphasized the need to better coordinate and integrate the activities and results of the 85 research projects into a risk-assessment framework. The goal: to use data sets in a rigorous evaluation process to make dose estimates for potential human and ecological impacts, particularly in Alaska, from the nuclear wastes the FSU had dumped in the Arctic. A Risk Assessment Integration Group (RAIG) was formed to conduct the assessment. The RAIG recognized at the outset of this risk-assessment phase that the risk analysis would have to depend on available ANWAP data and other published data sets, and that ongoing research would continue to generate new data even after the data cutoff point for timely preparation of the risk assessment. The RAIG has established an evaluation framework that, through an ongoing iterative process, can be enhanced as new information becomes available.

The risk assessment follows a traditional, internationally accepted radiological risk-assessment process. It uses models to make predictions, but also incorporates actual field measurements and laboratory data obtained from ANWAP scientists and the broader national and international scientific community. The risk-assessment team involved key scientists from Alaska (Douglas Dasher, Department of Environmental Conservation, and Todd O'Hara, North Slope Borough Department of Wildlife Management); Lawrence Livermore National Laboratory (David Layton, Mark Mount, Florence Harrison, and John Knezovich); Sandia National Laboratories (Rip Anderson, Mel Marietta, Leo Gomez, and Palmer Vaughn); Battelle Pacific Northwest Laboratories (William Templeton and Bruce Napier); and the Office of Naval Research (Marilyn Varela). This integrating team (the RAIG) identified discrete areas of focus and authorship for various components of the risk assessment; in the preparation of this report, the team relied upon the input of key ANWAP Principal Investigators, some of whose information was timely enough for use, and some not. Each section of the report identifies the authors. Although inputs from Russian contributors were instrumental in developing the description of the current disposition of FSU wastes, this report represents strictly a U.S. interpretation of the consequences implied by their information.

The sources of radioactive release evaluated in this report are those currently in or entering the Arctic Ocean. The coupled modeling and risk-assessment methodology developed for these marine sources, however, are applicable to other potential sources. Such sources could include nuclear submarines and decommissioning products, or stored spent nuclear fuel (SNF) at military bases 
in Murmansk or Vladivostok. While these sources potentially could be very large, this report does not address them because they are outside ANWAP's original mandate, and they are under Russian institutional control. It also does not directly address other Alaskan sources, such as residual contamination on Amchitka Island or residues from Project Chariot. These instances of localized Alaskan contamination are addressed only as they impact the current measurable background in Arctic waters.

This report is not the ANWAP Final Report of all research efforts. Much more ANWAP research work still is being finalized; thus, it has not yet become available for use in risk assessments. The authors of this risk assessment, however, have followed the development of the other ANWAP projects and anticipate that no yet-to-be-published work will greatly alter the conclusions of this report. Scientists involved in ANWAP have recommended many future research efforts; the 1996 Annual Synthesis Meeting comprehensively addressed future-work priorities, which are presented in the summary report of that meeting (ONR, 1997). Individual investigator reports in the annual program summary books for 1993 to 1994 (ONR 322-95-5) and 1995 (ONR 3322-96-16), the 1996 summary (in preparation), and the various ANWAP annual reports to Congress contain additional recommendations.

This risk-assessment report represents a stringent technical undertaking reflecting interdisciplinary collaboration and use of the most recent available data. The principal audience is the technical community, although the Executive Summary and the summary paragraphs within the various sections of the report should assist those unfamiliar with the radiological risk-assessment process and health physics. Another document, intended for a public audience, will complement this technical report.

Simultaneously with this ANWAP risk-assessment effort, the International Atomic Energy Agency (IAEA) International Arctic Seas Assessment Program (IASAP) has been conducting a major program focusing solely on the Kara Sea's FSU-dumped nuclear materials and localized Kara Sea impacts. The more extensive ANWAP project, which has involved some riverine land-based sources, as well as an assessment of cross-Arctic-basin transport processes for a focus on potential Alaskan consequences, complements the IAEA initiative. 


\title{
ACKNOWLEDGMENTS
}

\begin{abstract}
A s part of the peer-review process for this report, we solicited comments from ANWAP Principal Investigators as well as members of the Interagency Arctic Research Policy Committee and other external reviewers. We are grateful for comments and responses received from the following individuals:
\end{abstract}

Maggie Ahmaogak

Alaska Eskimo Whaling Commission

James Brooks

PDI-Brooks International

Michael Champ

Texas A\&M University

Lou Codispoti

Old Dominion University

Lee Cooper

Oak Ridge National Laboratory

John Diamante

Sidney Draggan

Christopher Nelson

Neal Nelson

William Wood

Jerry Leitch

Fran Stefan

Cathy Hill

U.S. Environmental Protection Agency

COL Al Schaffer

Office of the Under Secretary of Defense (Acquisition)

Molly Fayen

Charles Newstead

Robert Senseney

U.S. Department of State

Wayne C. Hanson

Hanson Environmental Services
John K. Hartsock

Carl Hild

Rural Alaska Community Action Program

Steven King

Naval Research Laboratory

Debra Mecse

U.S. Army Cold Regions Research and Engineering Laboratory

Benjamin P. Nageak

Mayor, North Slope Borough

Elizabeth D. Nobmann

Glen L. Sjoblom

Prasad Gogineni

National Aeronautics and Space Administration

William Fitzhugh

Smithsonian Institution

Ann Heinrich

Jerry Elwood

U.S. Department of Energy

Captain Richard Rooth

U.S. Coast Guard

Peter Hartsock

U.S. Department of Health and Human Services/

National Institute on Drug Abuse 
Curtis Olsen

U.S. Department of Energy

Ed Meyers

Renee Tatusko

National Oceanographic Atmospheric Administration

Philip S. Chen, Jr.

National Institutes of Health

James Devine

Bruce F. Molnia

U.S. Geological Survey

Charles E. Myers

National Scientific Foundation

Tom Curtin

Office of Naval Research

Mel Marietta

Rip Anderson

Sandia National Laboratories

Paul Becker

National Institute of Science and Technology
Walter B. Parker

Arctic Research Commission

Grace Egelund

Alaska Department of Health and Social Services

Peter Wallis

Tanana Chiefs Conference, Inc.

Douglas Dasher

Alaska Department of Environmental Conservation

Tom Albert

Todd O'Hara

Warren Matumeak

North Slope Borough Department of Wildlife

Management

Art Ivanoff

Maniilaq Association

Loretta Bullard

Alaska Eskimo Walrus Commission

Paul D. Moskowitz

Brookhaven National Laboratory

This work will be performed under the auspices of the U.S. Department of Energy at Lawrence Livermore National Laboratory under contract W-7405-ENG-48. 


\section{EXECUTIVE SuMMARY}

\section{Introduction}

$\mathrm{D}$

uring the Cold War, the handling of nuclear wastes from weapons-development facilities and naval operations was a classified topic, kept secret to hide the status and readiness of military forces. Beginning with the period of "glasnost," and continuing with the change in the government, information about the handling of nuclear wastes by agencies of the former Soviet Union (FSU) has become available. The principal U.S. Government response to the disclosures of dumping of radioactive wastes directly into the Arctic Ocean and into rivers that drain into the Arctic Ocean was the funding of the Arctic Nuclear Waste Assessment Program (ANWAP) in the Office of Naval Research (ONR). ANWAP supports several diverse projects studying the behavior, transport, and fate of radionuclides in the Arctic Ocean. This report describes an assessment of the potential risks to humans and the environment, particularly in the U.S. Alaskan Arctic, resulting from historic and ongoing FSU military waste-management activities. The assessment was conducted under the direction of the Risk Assessment Integration Group (RAIG), which consisted of several ANWAP investigators.

\section{Scope and Goals of the Assessment}

The primary goal of the assessment reported here is to evaluate the health and environmental threat to coastal Alaska posed by radioactive-waste dumping in the Arctic and Northwest Pacific Oceans by the FSU. In particular, the FSU discarded 16 nuclear reactors from submarines and an icebreaker in the Kara Sea near the island of Novaya Zemlya, of which 6 contained spent nuclear fuel (SNF); disposed of liquid and solid wastes in the Sea of Japan; lost a ${ }^{90} \mathrm{Sr}-$ powered radioisotope thermoelectric generator at sea in the Sea of Okhotsk; and disposed of liquid wastes at several sites in the Pacific Ocean, east of the Kamchatka Peninsula. In addition to these known sources in the oceans, the RAIG evaluated FSU waste-disposal practices at inland weapons-development sites that have contaminated major rivers flowing into the Arctic Ocean. The RAIG evaluated these sources for the potential for release to the environment, transport, and impact to Alaskan ecosystems and peoples through a variety of scenarios, including a worst-case total instantaneous and simultaneous release of the sources under investigation.

The risk-assessment process described in this report is applicable to and can be used by other circumpolar countries, with the addition of information about specific ecosystems and human life-styles. They can use the ANWAP risk-assessment framework and approach used by ONR to establish potential doses for Alaska, but add their own specific data sets about human and ecological factors.

The ANWAP risk assessment addresses the following Russian wastes, media, and receptors: 
- Dumped nuclear submarines and icebreaker in Kara Sea: marine pathways

- Solid reactor parts in Sea of Japan and Pacific Ocean: marine pathways

- Thermoelectric generator in Sea of Okhotsk: marine pathways

- Current known aqueous wastes in Mayak reservoirs and Asanov Marshes: riverine to marine pathways

- Alaska as receptor

For these wastes and source terms addressed, other pathways, such as atmospheric transport, could be considered under future-funded research efforts for impacts to Alaska. The ANWAP risk assessment does not address the following wastes, media, and receptors:

- Radioactive sources in Alaska (except to add perspective for Russian source term)

- Radioactive wastes associated with Russian naval military operations and decommissioning

- Russian production reactor and spent-fuel reprocessing facilities nonaqueous source terms

- Atmospheric, terrestrial and nonaqueous pathways

- Dose calculations for any circumpolar locality other than Alaska

These other, potentially serious sources of radioactivity to the Arctic environment, while outside the scope of the current ANWAP mandate, should be considered for future funding research efforts.

\section{Risk Assessment Technical Approach and Findings}

The preparation of this report followed a proven approach of evaluating the potential sources of release and selecting the dominant contributors, predicting the release rates of the dominant contributors into the environment, modeling the transport and deposition of these radionuclides, measuring and estimating their uptake into Arctic fish and marine mammals, and assessing the risks to the biota and humans as a result. This approach predicts the spatial and time scales for currently known and future releases of radioactivity from the source terms under examination, and thus can be used to guide monitoring efforts.

\section{Characterization}

The first principal activity for the risk assessment was to characterize the sources of radionuclides in the Arctic seas-not only the FSU sources of interest in the Kara Sea and Northwest Pacific, but potential sources through riverine transport from Russian watersheds to the Arctic Ocean. To place these sources into perspective and to obtain a comprehensive understanding, 
ANWAP also characterized the already existing fallout levels of key radionuclides, wastes from the Chernobyl incident and European fuel-reprocessing facilities at Sellafield (United Kingdom) and La Hague (France), and naturally occurring radioactivity.

Findings: Except for very localized instances in the Kara Sea near dumped reactors and nucleartesting sites, the already existing fallout levels and the Sellafield reprocessing source term now dominate in the Arctic.

\section{Radionuclide Screening}

The objective of the screening analysis was to identify the most important nuclides for focus from a risk standpoint from the radioactivity sources created by the FSU in the Kara Sea, the Northwest Pacific, and inland along the major Russian river systems.

Findings: The radionuclides that result in over $95 \%$ of the potential human and ecological risks are ${ }^{137} \mathrm{Cs},{ }^{239} \mathrm{Pu},{ }^{241} \mathrm{Am}$, and ${ }^{90} \mathrm{Sr}$. The primary potential risks from the submarine reactor cores in the Kara Sea arise from ${ }^{137} \mathrm{Cs}$, and the primary potential risks from the land-based sources arise from ${ }^{90} \mathrm{Sr}$.

\section{Release Scenarios}

The radionuclides in the reactors and other wastes dumped into the oceans must first escape from their containers before they can disperse through the environment. Several possible scenarios for future release of these radionuclides were considered for each waste source.

1. Kara Sea: Two scenarios were considered for the dumped submarines and icebreaker: (a) a worst-case condition, where a breaching of containment occurs and all of the materials are released instantaneously, and (b) a time-varying best- estimate case, in which the radionuclides are released as the SNF corrodes. Both scenarios were based on the results of the Source-Term Working Group of the International Arctic Seas Assessment Program, sponsored by the International Atomic Energy Agency (IAEA). In the worst case, the total inventory of each radionuclide, about $4,700,000 \mathrm{GBq}$, is released instantaneously. In the bestestimate case, the maximum Kara Sea release occurs in about the year 2050, after seawater is assumed to enter the unprotected reactor compartments.

Findings: the total annual release never rises above $1,300 \mathrm{GBq} / \mathrm{yr}$. The rate drops from 1,000 $\mathrm{GBq} / \mathrm{yr}$ in the year 2100 to $1 \mathrm{GBq} / \mathrm{yr}$ in the year 3000. These two scenarios tend to limit the potential impacts.

2. Sea of Japan and Pacific Ocean, East Coast of Kamchatka: A worst-case assumption was taken that the dumped reactor solid objects are unenclosed and subject to corrosion, at a corrosion rate of $0.05 \mathrm{~mm} / \mathrm{yr}$. Sedimentation cover is assumed to occur by 1,000 years into the future.

Findings: the total release rate in the Sea of Japan begins at about $1 \mathrm{GBq} / \mathrm{yr}$ and drops to less than $0.1 \mathrm{GBq} / \mathrm{yr}$ beyond the year 4000; and in the Pacific Ocean releases start below 0.01 $\mathrm{GBq} / \mathrm{yr}$ over 1,000 years, and fall to $0.000000001 \mathrm{GBq} / \mathrm{yr}$. 
3. Sea of Okhotsk: Instantaneous release of the $11,000,000 \mathrm{GBq}$ of ${ }^{90} \mathrm{Sr}$ in the radioisotope thermoelectric generator is assumed for analysis.

Findings: The RAIG assumes that because the RTG is reportedly hermetically sealed and solidly constructed, the radioisotopes will decay before they are released.

4. West Siberian Basin: Four scenarios are considered: (a) baseline release based on actual historical record; (b) Mayak reservoir failure releasing all ${ }^{90} \mathrm{Sr}$ within one year; (c) Mayak reservoirs releasing radioactivity to near-surface groundwater under worst-case conditions, and (d) remobilization of ${ }^{90} \mathrm{Sr}$ from the Asanov Marshes, with a one-year release period.

Findings: The upper bound of the current ongoing baseline release, from global fallout plus past releases from the land-based facilities, is $40,000 \mathrm{GBq} / \mathrm{yr}$ of ${ }^{90} \mathrm{Sr}$; this rate will fall slowly over time with radioactive decay of the sources. All the other possible scenarios result in about the same numerical result, a flux rate of about 1,400,000 GBq/yr for only one year.

\section{Transport Analysis}

The next step in the risk assessment was to evaluate the movement of the estimated potential releases of radionuclides in Arctic waters using oceanographic models. A compartmental model was developed, incorporating information from other existing compartmental, ice-ocean, and riverine models. Additionally, the role of sea ice in transport of nuclides was a major focus. Measured historic radionuclide levels in the Arctic Ocean, the Sea of Japan, and areas in the Russian source-term areas were compared with the predicted concentrations from the modeling.

Findings: Sea-ice formation in the Kara Sea is not a likely vehicle for long-range cross-Arctic-basin transport, and total transport by ice via a marine pathway to Alaska would be small. Individual radionuclide characteristics are considered, as well as properties of the marine environment. For example, ${ }^{239} \mathrm{Pu}$ and ${ }^{241} \mathrm{Am}$ will tend to be influenced more by particles and sediments, by becoming bound to them, than will ${ }^{137} \mathrm{Cs}$ and ${ }^{90} \mathrm{Sr}$. The range of radionuclide concentrations predicted from the model is consistent with those levels measured historically.

\section{Bioconcentration in Food Webs}

In addition to actual measurements of radionuclide levels in biota, the radiological risk assessments used bioconcentration factors (BCFs) to extrapolate concentrations of radionuclides in scawater with levels that can be expected in biota over time. Current radionuclide levels in biota and water were measured to determine BCFs that are used in the risk assessment. An international panel of experts determined that BCFs for polar organisms would be the same as or similar to nonpolar, temperate water species. They decided that the factors were sufficiently similar, and confirmed that decades of historical data, as summarized in the IAEA document TecDoc 2471985 , could be used in this risk assessment. BCFs were used to predict uptake of Arctic-disposed radionuclides from the FSU, and of naturally occurring radionuclides, by important dietary species for man, and those that are an important part of food chains leading to man. 


\section{Assessment of Risk to Marine Organisms}

The RAIG evaluated radionuclide levels in environmental media resulting in significant potential detrimental effects on reproductive success in sensitive Alaskan marine species. We assess the potential for radiological effects by comparing the dose rates predicted using FSU worstcase-release scenarios to our dose-rate no-observable-effects levels (NOELs) for mortality, sterility, and reduced fertility.

Findings: Radionuclides in Alaskan coastal waters and sediments and in selected marine mammals, fishes, and other biota are below levels of concern for bioeffects. Predicted concentrations of radionuclides from FSU sources are not expected to affect survival of reproducing populations of marine mammals, fishes, and other biota of human dietary importance in Alaska. The predicted dose rates are so low in all cases as to make it very unlikely that any loss of endangered species or any significant ecological impacts will occur in areas away from the immediate FSUdisposal sites.

\section{Assessment of Risk to Humans}

The RAIG, using available data on subsistence diets, focused on people in north and northwestern coastal Alaska whose subsistence diet includes fish and marine mammals from the Arctic Ocean. The RAIG estimated peak radiation doses for individuals living in a variety of communities and consuming a variety of diets.

Findings: The largest doses to individuals living in Alaskan coastal communities who consume subsistence seafoods come from naturally occurring ${ }^{210} \mathrm{Po}$, followed by ${ }^{137} \mathrm{Cs}$ and ${ }^{90} \mathrm{Sr}$ from global fallout. The highest predicted doses from FSU sources result from the instantaneous release of radionuclides contained in reactors dumped in the Kara Sea, but these doses are well below background levels and global fallout. The predicted acute and chronic discharges from the $\mathrm{Ob}$ and/or Yenisey rivers produce doses similar to the Kara Sea sources.

This report provides a means of estimating individual radiation doses to help interested Alaskan citizens evaluate their own particular circumstances.

\section{Overall Conclusions}

Currently, there is no indication that FSU dumping activities caused elevated concentrations of radionuclides in Alaskan waters. To date, the predicted concentrations of radionuclides in Alaskan waters from FSU dumping are so low in all cases that it is highly unlikely that any significant ecological impacts will occur in any areas outside the immediate Russian disposal sites.

The potential human health risks associated with ingesting Alaskan seafoods containing radionuclides derived from the releases evaluated are extremely low. Those wastes pose no threat to human health; Alaska Native communities, therefore, need not alter any of their dietary habits associated with subsistence foods obtained from Alaskan waters. 


\section{Recommendations}

Since the initiation of funding for ANWAP in 1993 and the risk assessment project for Alaska, which began in 1995, other sources of radioactivity have been identified and warrant international attention, such as Russian naval military activities involving storage, decommissioning, and radioactive-waste management. Source-term data regarding nuclear-weapons production and reprocessing facilities also need refinement.

\section{Monitoring}

It should again be reiterated that as far as even the marine sources and pathways that ANWAP investigated, there are gaps in our fully understanding many processes governing transport and ultimate disposition of Russian radioactive materials. The risk assessment bounded the possibilities of exposure through worst-case, total-release assumptions, resulting in dose values below levels of concern for Alaska, across the Arctic Basin from Russia. Nonetheless, it would be valuable to concentrate more effort on biological processes, including migratory patterns and U.S. and other countries' fisheries habits. The ANWAP research revealed a dearth of information regarding radionuclide uptake in Arctic marine mammals. Although it is unlikely that additional information would change the conclusions of this report, more sampling of marine mammals, of organs as well as muscle consumed by residents, would strengthen the ability to predict impacts to biota as well as to man. Concurrent sampling of ocean water would help develop more accurate BCFs. Similar information about uptakes in birds, eggs, and other commonly eaten foods is needed. This research need not be performed only in Alaskan waters-data from other northern countries also would be valuable. Seasonal biogeochemical data also would be valuable from a risk-assessment standpoint.

\section{Source-Term Research}

Much of the information available to the RAIG on the Russian inland contamination sources was limited. Research needs include the following: additional international research on the current contents of the FSU fuel-cycle facilities at Krasnoyarsk, Tomsk, and Mayak; the inventories and availabilities of all radionuclides in lakes, holding ponds, and groundwater sources to better define the long-term potential for releases; and better detail on the long-lived, environmentally mobile radionuclides other than the easily detected ${ }^{137} \mathrm{Cs}$ or ${ }^{90} \mathrm{Sr}$.

\section{Modeling}

Shelf-to-slope-to-Arctic-Basin circulation and transport dynamics has just begun to be understood and incorporated into models. Such data sets also are needed for model validation. The experience gained in conducting the assessment for this report shows that there is an opportunity for closer cooperation between assessment modelers and the scientific groups developing ocean-circulation models or performing tracer studies. The various groups involved in research on Arctic contamination should continue to work together to provide integration of ongoing experimental work into useful assessment information. 


\section{Other}

Additional data on the transport of radioactive materials in the Arctic Ocean could benefit the assessment of numerous other contaminants. Much of the data used in the preparation of this report is of recent origin and needs validation or verification. Particularly important would be more information on Arctic currents: their stability and longevity, influence of wind, and possible seasonal changes.

Although our analyses suggest that ice transport of radionuclides is no major mechanism for moving contamination towards Alaska, it does appear to somewhat increase the transport toward Greenland. If future assessments for other Arctic countries consider the models and techniques developed for this report, more information on the mechanisms of incorporation of sediments and contaminants in ice, and their transport, would be valuable.

The results of this report suggest that the largest impacts would be in the immediate vicinity of the Russian waste dump sites. Future monitoring to evaluate further the sources, locate others, and validate the modeled source terms is suggested.

This report focuses on aquatic sources and foods. It appears that natural background levels of ${ }^{210} \mathrm{Po}$ and radionuclides from global fallout dominate the doses. For a complete perspective, equivalent assessments of the terrestrial pathways for native subsistence life-styles would be beneficial.

This report addresses existing radioactive wastes in the marine environment and ongoing and potential inland releases. Additional sources of radioactivity in the Russian Arctic potentially exist, particularly nuclear wastes associated with Russian naval activities in Murmansk, Vladivostok, and other naval bases. The techniques developed here also could help evaluate the possible impact of hypothetical, or future actual, accidents in those areas. 


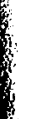




\section{Contents}

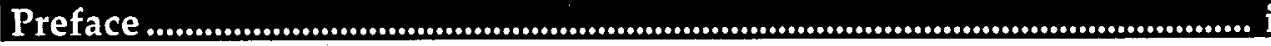

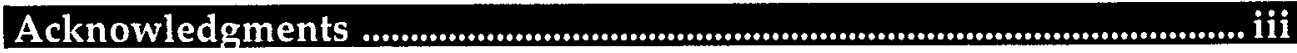

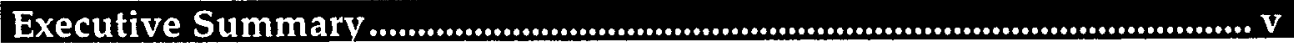

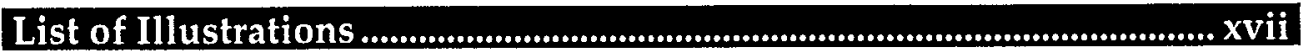

Acronyms and Abbreviations ............................................................ xxiii

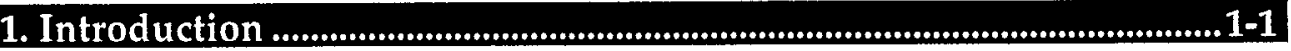

1.1 Nuclear Wastes Addressed ............................................................................. 1-2

1.2 Risk-Assessment Methodology ................................................................... 1-2

1.3 Scope of the Risk Assessment ................................................................ 1-4

2. Source-Term Analyses of Potential Radionuclide Releases Relevant to the Arctic Seas and Northwest Pacific Ocean ........................................2-1

2.1 Existing Sources of Radionuclides in Arctic Waters ..................................... 2-2

2.2 Description of Marine Disposal Sites .............................................................. 2-4

2.2.1 Kara Sea Marine Nuclear Reactors ........................................................... 2-4

2.2.2 Sea of Japan; Sea of Okhotsk; Pacific Ocean, East Coast of Kamchatka ... 2-9

2.3 Sources in the West Siberian Basin ...........................................................2-15

2.4 Radionuclide Inventories ....................................................................... 2-16

2.4.1 Kara Sea ................................................................................................ 2-16

2.4.2 Sea of Japan and Pacific Ocean, East Coast of Kamchatka .................. 2-21

2.4.3 Sea of Okhotsk ........................................................................................ 2-21

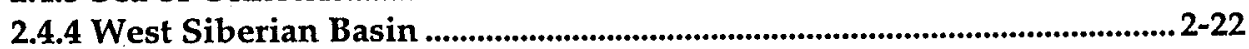

2.5 Radionuclide Screening ............................................................................. 2-25

2.5.1 Kara Sea and West Siberian Sources ................................................... 2-25

2.5.2 Northwest Pacific Ocean Sources .......................................................... 2-29

2.6 Release Scenarios ................................................................................... 2-32

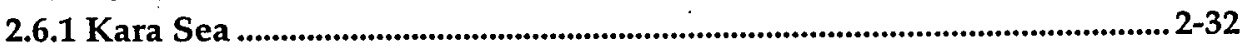

2.6.2 West Siberian Basin .......................................................................... 2-33

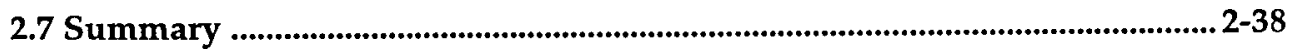

3. Transport of Radionuclides in the Arctic Seas ...................................3-1

3.1 Selection Criteria for Radionuclide Transport Models .................................3-2

3.2 Simulating Radionuclide Transport in the Arctic Ocean ..............................3-2

3.2.1 Mathematical Formalism for the Compartmental Model ....................... 3-4

3.2.2 Radionuclide Partitioning Between Sediment and Seawater ................ 3-6

3.2.3 Sediment-Related Transport Processes .................................................... 3-9

3.2.4 Role of Ice Transport ............................................................................. 3-10 
3.3 Transport Simulations: The RAIG and Nielsen et al. (1995) Compartmental Models 3-12

3.3.1 RAIG Compartmental Model 3-12

3.3.2 Compartmental Model of Nielsen et al. (1995) ............................................. 3-20

3.3.3 Model Intercomparisons and Sensitivities ............................................. 3-21

3.3.4 Simulations of Radionuclide-Release Scenarios .................................... 3-28

3.3.5 Predicted Radionuclide Concentrations v. Historic Levels .................. 3-33

3.4 Summary . 3-35

4. Bioconcentration of Radionuclides in Marine Food-Web Organisms.. 4-1

4.1 Definition of Bioconcentration Factors ............................................................. 4-1

4.2 Bioconcentration Factors for Radionuclides Derived from FSU Sources ... 4-3

4.3 Bioconcentration Factors for Naturally Occurring Radionuclides ................ 4-5

4.4 Variabilities in Bioconcentration Factors ........................................................... 4-6

4.5 Estimated and Measured Concentrations of Radionuclides in Marine

Species

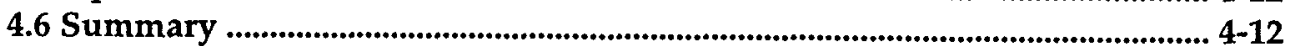

5. Assessment of Risks to Marine Aquatic Populations Resulting from

Exposures to Radionuclides in Arctic Seas ........................................... 5-1

5.1 Arctic Marine Ecological Systems ................................................................ 5-2

5.2 Tier-I Assessment of Doses to Biota ............................................................... 5-4

5.2.1 Exposure Pathways of Aquatic Populations ........................................... 5-4

5.2.2 Dosimetry Models .............................................................................................. 5-4

5.2.3 Standards for Protection of Aquatic Life .............................................. 5-6

5.2.4 Doses and Dose Rates Potentially Producing Significant Detrimental Effects 5-7

5.2.5 Dose Rates from Potential FSU Radionuclide Contamination of the

Arctic Seas

5-13

5.2.6 Dose Rates from Radionuclides Occurring Naturally ............................ 5-17

5.2.7 Dose Rates from Fallout Radionuclides in the 1960s and 1990s .......... 5-18

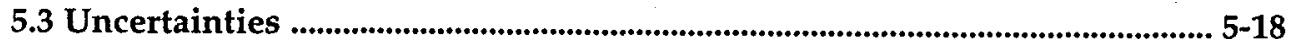

5.3.1 Temperature Effects ......................................................................................18

5.3.2 Interaction of Radionuclides with Other Contaminants ....................... 5-18

5.4 Tier-II and Tier-III Risk Assessments ...................................................... 5-18

5.5 Summary ............................................................................................................ 5-19

6. Assessment of Risks to Alaskan Populations from Exposures to

Radionuclides in Subsistence Diets ....................................................... 6-1

6.1 Subsistence Life-Style .................................................................................. 6-2

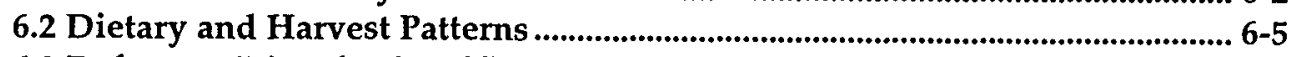

6.3 Reference Diets for Specific Communities …......................................... 6-6

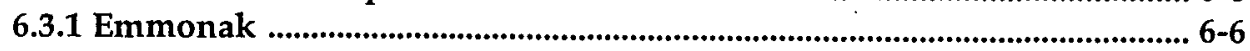

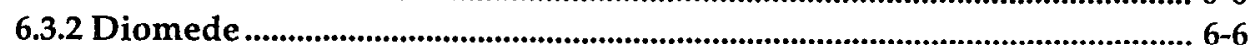

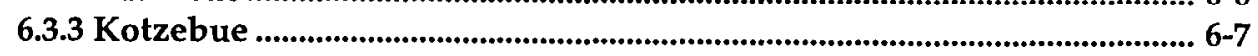

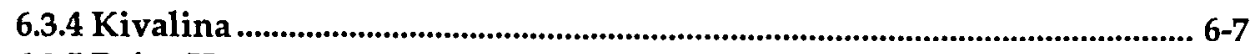

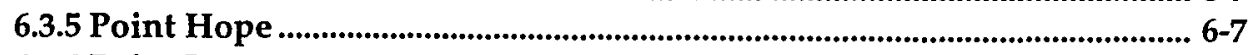

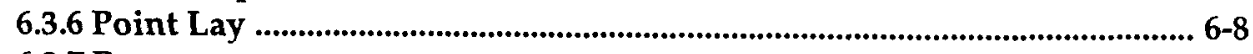

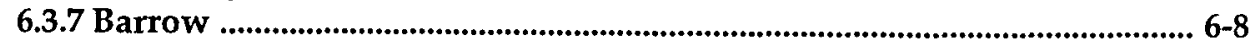

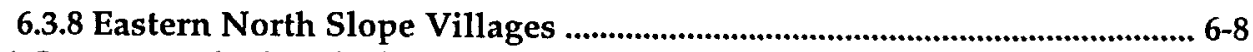

6.4 Current and Historical Doses from Natural and Background Sources ....... 6-9 
6.4.1 Radioactive Materials in Rocks and Soil ................................................. 6-9

6.4.2 Radioactive Materials in the Body ........................................................6-9

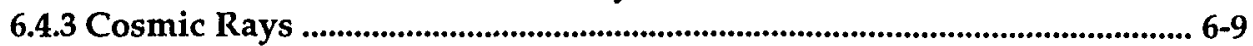

6.4.4 Internal Doses from Natural Radioactivity in Seafoods ........................ 6-10

6.4.5 Internal Doses from Historical Man-Made Sources ................................. 6-11

6.5 Projected Doses from Russian Nuclear Sources .............................................. 6-11

6.5.1 Doses Derived from Nuclear Materials Disposed of in the Kara Sea .... 6-12

6.5.2 Doses from Releases to the $\mathrm{Ob}$ and Yenisey Rivers ................................ 6-14

6.6 Uncertainty and Sensitivity Analysis .............................................................. 6-14

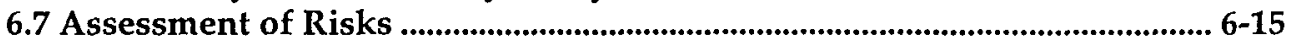

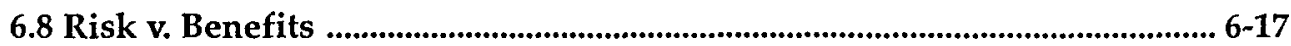

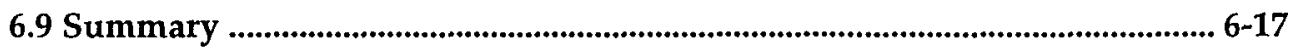

7. Assessment Results, Conclusions, and Recommendations ............... 7-1

7.1 Assessment Context ....................................................................................... 7-1

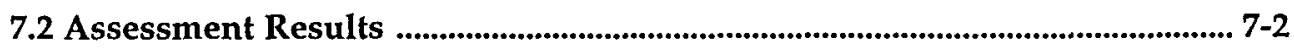

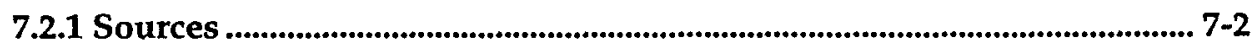

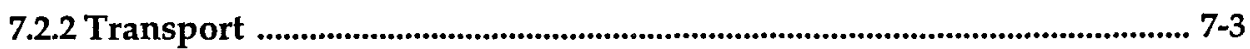

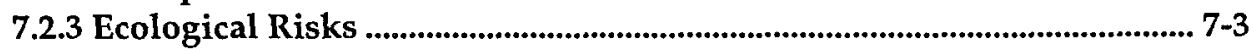

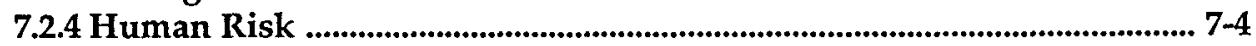

7.3 Extension of Results to Other Contexts ........................................................ 7-4

7.3.1 Non-Subsistence Residents ...................................................................... 7-4

7.3.2 Visitors and Tourism ........................................................................................ 7-5

7.3.3 Alaska Fishing Industry .................................................................................. 7-5

7.4 Possible Use of Results in Future Contexts ......................................................... 7-5

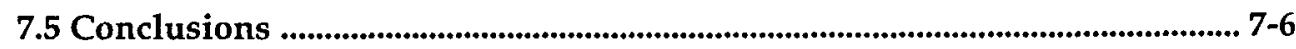

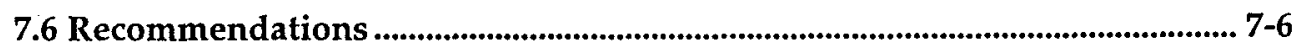

7.6.1 Monitoring ...................................................................................................... 7-6

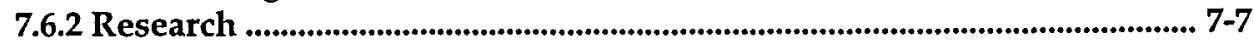

7.6.3 Modeling …............................................................................................................... 7-7

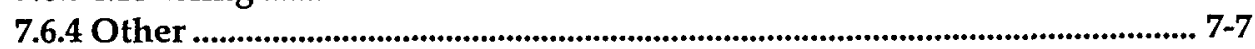

Appendix A: Ecosystems in Arctic Areas of Concern .............................. A-1

A.1 Areas of Concern .......................................................................................... A-1

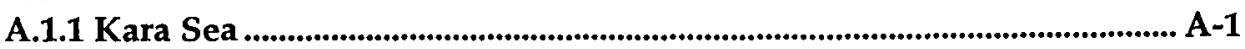

A.1.2 Alaskan Shelf: Chukchi and Beaufort Seas .............................................. A-1

A.1.3 Northern Bering Sea .............................................................................. A-2

A.2 Types of Ecosystems ....................................................................................... A-2

A.2.1 Polar-Ice Ecosystems ........................................................................... A-2

A.2.2 Benthic-Pelagic Ecosystems .............................................................................. A-3

A.2.3 Offshore Pelagic Ecosystems ……......................................................... A-3

A.2.4 Coastal Lagoons ........................................................................................ A-3

A.3 Basic Structure and Composition of Ecosystems ............................................... A-4

A.4 Marine Populations at Risk ................................................................................ A-4

A.4.1 Ecologically Important Marine Populations at Risk ............................ A-15

A.4.2 Economically Important Marine Populations at Risk .......................... A-15

Appendix B: Radiation Doses and Dose Rates Resulting in Mortality .... B-1

B.1 Radiation Doses Resulting in Mortality .............................................................. B-1

B.2 Radiation Dose Rates Resulting in Mortality .................................................. B-1 


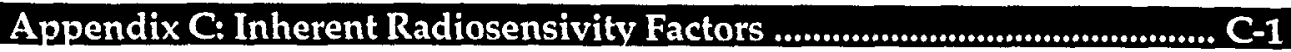

C.1 Cell Repopulation and Specialization or Differentiation ............................. C-1

C.2 Biological Repair ................................................................................................... C-1

C.3 Adaptive Responses ..................................................................................................... C-2

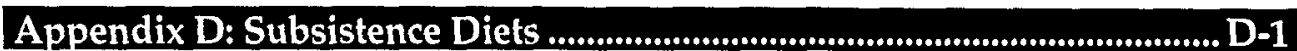

Appendix E: Worksheet for Estimating Individual Doses ...................... E-1

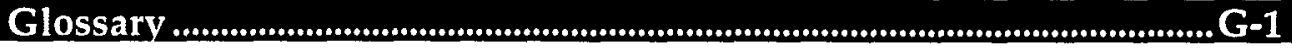

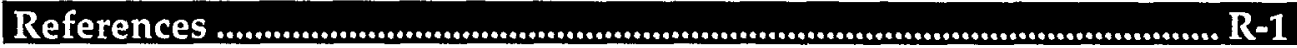




\section{List OF ILLUSTRATIONS}

\section{FIGURES}

Figure 1-1. Locations of the nuclear wastes of concern derived from the former Soviet Union 1-2

Figure 1-2. Overview of the basis risk-assessment methodology 1-3

Figure 2-1. A map of Novaya Zemlya showing locations of the disposal sites 2-5

Figure 2-2. Liquid radioactive waste disposal sites in the Sea of Japan; Sea of Okhotsk; and the Pacific Ocean, east coast of Kamchatka 2-13

Figure 2-3. Solid radioactive waste disposal sites in the Sea of Japan; Sea of Okhotsk; and the Pacific Ocean, east coast of Kamchatka 2-13

Figure 2-4. Locations of nuclear-weapons plants in the West Siberian Basin 2-15

Figure 2-5. Disposal sites for reactor-related unenclosed solid objects in the Sea of Japan and the Pacific Ocean, east coast of Kamchatka 2-22

Figure 2-6. The reservoirs constructed to prevent Techa River contamination from liquid radioactive discharges from the Chelyabinsk-40 operation. 2-25

Figure 2-7. Time-varying release rates of radionuclides from naval reactors dumped in the Kara Sea (from IAEA, 1997) $2-34$

Figure 3-1. Basic compartmental structure for simulating the advective transport of radionuclides in water between two stacked water compartments as well as adjacent water compartments. 3-3

Figure 3-2. Mean field of ice motion in the Arctic Ocean for the years 1979 through 1994 3-11

Figure 3-3. Locations of the water compartments used in the RAIG model 3-13

Figure 3-4. Water exchanges between ocean compartments in the RAIG model 3-14

Figure 3-5. Locations of the surface ocean compartments used in the Nielsen et al. (1995) model 3-20

Figure 3-6. Modification of the compartmental structure used in Nielsen et al. (1995) 3-21

Figure 3-7. Concentrations of ${ }^{137} \mathrm{Cs}$ in the Chukchi, Beaufort, and Bering seas resulting from an instantaneous release of $1 \mathrm{TBq}$ in the Kara Sea 
Figure 3-8. Concentrations of ${ }^{241} \mathrm{Am},{ }^{137} \mathrm{Cs},{ }^{239} \mathrm{Pu}$, and ${ }^{90} \mathrm{Sr}$ in the Chukchi Sea resulting from the timevarying release of radionuclides from the Kara Sea nuclear wastes

Figure 3-9. Concentrations of ${ }^{241} \mathrm{Am},{ }^{137} \mathrm{Cs},{ }^{239} \mathrm{Pu}$, and ${ }^{90} \mathrm{Sr}$ in the Beaufort Sea resulting from the timevarying release of radionuclides from the Kara Sea nuclear wastes

3-28

Figure 3-10. Concentrations of ${ }^{241} \mathrm{Am},{ }^{137} \mathrm{Cs}^{239} \mathrm{Pu}$, and ${ }^{90} \mathrm{Sr}$ in the Bering Sea resulting from the time-varying release of radionuclides from the Kara Sea nuclear wastes

Figure 3-11. Concentrations of ${ }^{90} \mathrm{Sr}$ in the Beaufort, Bering, and Chukchi seas resulting from the accidental release of liquid waste from Mayak 3-31

Figure 3-12. Concentrations ${ }^{137} \mathrm{Cs}$ in the Beaufort, Bering, and Chukchi seas resulting from the accidental release of liquid waste from Mayak 3-32

Figure 3-13. Concentrations ${ }^{90} \mathrm{Sr}$ in the Beaufort, Bering, and Chukchi seas resulting from the chronic release of liquid wastes and watershed runoff into the $\mathrm{Ob}$ and Yenisey rivers 3-33

Figure 4-1. Log probability plots of the bioconcentration factors for ${ }^{137} \mathrm{Cs}$ in seabirds and fish, and for ${ }^{90} \mathrm{Sr}$ in fish

Figure 5-1. Impact of mutagens on genetic material of cells 5-7

Figure 5-2. For the same $L_{50}$ value, the shape of species dose-response curve that occurs from radiation may differ significantly 5-13

Figure 6-1. Coastal communities of Alaska addressed in the risk assessment of nuclear wastes derived from the former Soviet Union 6-2

Figure 6-2. Number of subsistence-derived meals consumed each week by residents of the North Slope Borough in Alaska 6-4

Figure 6-3. Number of subsistence-derived meals consumed each week by Point Lay residents 6-4

Figure A-1. Food chain of benthos-feeding marine mammals A-10

Figure A-2. Food chain of piscivorous-feeding marine mammals A-11

Figure A-3. Food chain of a mixed-feeding marine mammal A-12

Figure A-4. Food chain of a planktivorous marine mammal A-13

Figure A-5. Food chain of the polar bear, a marine mammal A-14 


\section{TABLES}

Table 2-1. Estimated inventories of ${ }^{137} \mathrm{Cs}$ and ${ }^{90} \mathrm{Sr}$ in the Arctic Ocean from various sources (excluding ${ }^{137} \mathrm{Cs}$ in Kara Sea waste sites) (Aarkrog, 1994)

Table 2-2. Pertinent disposal information for the marine reactors dumped in the Kara Sea ...... 2-6

Table 2-3. Pertinent disposal information for the liquid and solid radioactive waste dumped in the Sea of Japan (Yablokov et al., 1993).

Table 2-4. Pertinent disposal information for the liquid radioactive waste dumped in the Sea of Okhotsk, as presented in the White Book (Yablokov et al., 1993)...

Table 2-5. Pertinent disposal information for the liquid and solid radioactive waste dumped in the Pacific Ocean, east coast of Kamchatka, as presented in the White Book (Yablokov et al., 1993) .

Table 2-6. Estimated 1994 radionuclide inventories of fission products, activation products, and actinides in the marine reactors dumped in the Kara Sea (Sivintsev, December 1993, August 1994, and October 1995; Yefimov, 1944)

Table 2-7. Estimated 1994 activity of long-lived radionuclides at each disposal site from the marine reactors dumped in the Kara Sea (from IAEA, 1997; based on October 1995)

Table 2-8. Estimated 1994 activity of long-lived activation products in the reactor-related unenclosed solid radioactive waste dumped in the Sea of Japan and the Pacific Ocean, east coast of Kamchatka

Table 2-9. Summary of the total radionuclide inventories for nuclear wastes at Tomsk 7, Krasnoyarsk 26, and Mayak (from Bradley and Jenquin, 1995)

Table 2-10. Inventories of ${ }^{90} \mathrm{Sr}$ and ${ }^{137} \mathrm{Cs}$ dissolved in wastewaters stored in reservoirs associated with Mayak facility (from Bradley and Jenquin, 1995).

Table 2-11. Input parameters for use in the dose-based screening analysis of radionuclides 2-30

Table 2-12. Results of the dose-based ranking of the radionuclides present in the Kara Sea dump sites. 2-31

Table 2-13. Estimates of the maximum fluxes of ${ }^{9} \mathrm{Sr}$ to the surface water from the discharge of contaminated groundwater.

Table 3-1. Sediment-water distribution coefficients for Am, Cs, Pu, and $\mathrm{Sr}$ for Kara Sea sediments ....... 3-8 is

Table 3-2. Data on compartment volumes, depths, sediment loadings, and sediment deposition for the RAIG compartmental model 3-18 (1)

Table 3-3. Volumetric exchanges of water between compartments of the RAIG compartmental model .. 3-19 के.

Table 3-4. Data on compartment volumes, depths, sediment loadings, and sediment deposition for the modified Nielsen et al. (1995) compartmental model 
Table 3-5. Volumetric exchange of water between compartments of the modified Nielsen et al. (1995) compartmental model

Table 3-6. Predicted concentrations of ${ }^{241} \mathrm{Am},{ }^{137} \mathrm{Cs}$, and ${ }^{239} \mathrm{Pu}$ in the Beaufort and Chukchi Seas after an instantaneous release of $1 \mathrm{TBq}$ of each radionuclide in the Kara Sea

Table 3-7. Predicted concentrations of ${ }^{241} \mathrm{Am},{ }^{137} \mathrm{Cs}$, and ${ }^{239} \mathrm{Pu}$ in the Beaufort and Chukchi Seas after an instantaneous discharge of $1 \mathrm{TBq}$ of each radionuclide to the Kara Sea estuary from the $\mathrm{Ob}$ or Yenisey rivers

Table 3-8. Comparison of water exchange rates for the Arctic Ocean 3-25

Table 3-9. Concentrations associated with peak doses resulting from different source-term scenarios ... 3-30

Table 4-1. Recommended bioconcentration factors for fish flesh in temperate and Arctic waters 4-4

Table 4-2. Actual and recommended bioconcentration factors for sea mammal muscle (from IAEA Working Group)

Table 4-3. Actual and recommended bioconcentration factors for seabirds in the Arctic (from IAEA Working Group)

Table 4-4. Bioconcentration factors for fish tissues based on measured values of nuclides in water and fish for Arctic Waters (from IAEA Working Group)

Table 4-5. Bioconcentration factors for seabirds (from IAEA Working Group) $4-9$

Table 4-6. Bioconcentration factors (unitless) selected for use in risk assessment for different groups of marine organisms in Arctic seas.

Table 4-7. Bioconcentration factors $\left(\mathrm{m}^{3} / \mathrm{kg}\right)$ selected for use in risk assessment for different groups of marine organisms in Arctic seas

Table 5-1. Unit-dose-rate conversion factors for marine organisms 5-6

Table 5-2. Changes in the radiosensitivity of rainbow trout, Salmo gairdnerii, exposed to acute radiation during development (Welander, 1954; Welander et al., 1949) 5-9

Table 5-3. Comparison of sensitivity of reproductive tissues of invertebrates, fishes, and mammals exposed to acute radiation (dose in Gy) 5-10

Table 5-4. Comparison of sensitivity of reproductive tissues of invertebrates, fishes, and mammals exposed chronically to radiation (dose rate in $\mathrm{mGy} / \mathrm{h}$ ). 5-11

Table 5-5. Dose rates for fishes and invertebrates resulting from background levels and instantaneous releases of radionuclide inventories in the Kara Sea and $\mathrm{Ob}$ and Yenisey rivers 5-14

Table 5-6. The doses and dose rates resulting in mortality, sterility, and decreased fertility in groups of mammals, fishes, and invertebrates and the recommended no-observable-effect levels (NOELs) .......... 5-16

Table 6-1. Census data for coastal communities in Alaska in 1990 (Alaska Dept. of Community and Regional Projects) 
Table 6-2. Background doses resulting from the ingestion of ${ }^{210} \mathrm{Po}$ in seafoods 6-10

Table 6-3. Doses associated with the consumption of seafoods during the 1960 s that contain ${ }^{241} \mathrm{Am},{ }^{137} \mathrm{Cs}$, ${ }^{239} \mathrm{Pu}$, and ${ }^{90} \mathrm{Sr}$ present in Arctic waters as a result of nuclear fallout from weapons testing .................... 6-11

Table 6-4. Doses associated with the consumption of seafoods during the 1990 s that contain ${ }^{241} \mathrm{Am},{ }^{137} \mathrm{Cs}$, ${ }^{239} \mathrm{Pu}$, and ${ }^{90} \mathrm{Sr}$ present in Arctic waters as a result of nuclear fallout from weapons testing

6-12

Table 6-5. Summary of the doses predicted for different Alaskan coastal communities, diets, and release scenarios for FSU nuclear wastes. 6-13

Table A-1. Ecology of the Alaskan Shelf area: Chukchi and Beaufort seas A-4

Table B-1. Range of $L_{50} s$ obtained from acute radiation of adult vertebrate organisms from different taxonomic groups

Table B-2. Range of $\mathrm{LD}_{50} \mathrm{~s}$ obtained from acute radiation of invertebrate organisms from different taxonomic groups

Table B-3. Comparison of sensitivity of different endpoints for the worm Neanthes arenaceodentata receiving acute irradiation

Table D-1. Representative diet for Kivalina, Alaska for selected years (Alaska Department of Fish and Game, 1995)

Table D-2. Representative diet for Emmonak, Alaska for 1980 (Alaska Department of Fish and Game, 1995) ..... D-3

Table D-3. Representative diet for Point Lay, Alaska for 1987 ( Nlaska Department of Fish and Game, 1995) ....... D-4

Table D-4. Representative diet for Barrow, Alaska for the years 1987-1989 (Alaska Department of Fish and Game, 1995) D-5.

Table D-5. Consumption of subsistence food for Broughton Island, NWT (Health Canada, 1995) ....... D-6

Table D-6. Estimated food consumption of adults living in coastal villages of the 1960s (from Wilimovsky and Wolfe, 1966)

Table D-7. Estimated food consumption of adults living in Point Hope, Alaska in the 1960s (from Wilimovsky and Wolfe, 1966)

Table D-8. Estimated food consumption of adults living in Barrow, Alaska in the 1960s (from Wilimovsky and Wolfe, 1966)

Table D-9. Estimated food consumption of adults living in Diomede, Alaska in the 1960s (from Wilimovsky and Wolfe, 1966)

Table D-10. Estimated food consumption of adults living in Kotzebue, Alaska in the 1960s (from Wilimovsky and Wolfe, 1966)

Table E-1. Estimation of individual radiation doses for Alaskan communities located adjacent to the Beaufort, Bering, and Chukchi seas E-3 


\section{ACrONYMS AND AbBREVIATIONS}

ADF\&G: Alaska Department of Fish and Game

ANWAP: Arctic Nuclear Waste Assessment Program

AORS: Atlantic Ocean and related seas into a single ocean compartment (denoted)

BCF: Bioconcentration factor

Bq: Becquerel

BEIR IV, V: Biological Effects of Ionizing Radiation Committees IV and V

BIORAD: An ecological model

CCR: Control or compensation rod

cgs: Centimeter, gram, second

CM: Compartmental model

S: Collective Dose Equivalent

CRITR: An ecological model

Ci: Curie

DCF: Dose-conversion factor

DNA: Deoxyribonucleic acid

$\left(\mathrm{H}_{\mathrm{E}}\right)$ : Effective Dose Equivalent

EXTREM III: An ecological model

F: Furfurol

FSU: Former Soviet Union

Gy: Gray

GSD: Geometric standard deviation

IILW: High-level (radioactive) waste 
IAEA: International Atomic Energy Agency

IASAP: International Arctic Seas Assessment Program

IPPE: Institute of Physics and Power Engineering

J: Joule

$K_{\mathrm{d}}$ : Sediment distribution coefficient, reflecting how strongly nuclides will be associated with sediment, and their availability to the water column (higher values show stronger sediment interaction)

$\mathrm{LD}_{50 / 30}$ : Lethal dose killing $50 \%$ in 30 days

LLW: Low-level (radioactive) waste

LMR: Liquid metal reactor

LRW: Liquid radioactive waste

MW: Megawatt

NOELs: No-observable-effects levels

NOGAPS: Naval Operational Global Atmospheric Prediction System

OCM: Ocean-circulation model

ONR: Office of Naval Research

PFIG: Term for a specific computer program

PSDD: Point-Source Dose Distribution

PWR: Pressurized water reactor

RAIG: Risk Assessment and Integration Group

RC: Reactor compartment

Rem: Roentgen equivalent man

RPV: Reactor pressure vessel

RRCKI: Russian Research Center "Kurchatov Institute"

RTG: Radioisotope thermoelectric generator

RW: Radioactive waste

SG: Steam generator

xxiv 
SGI: Steam-generating installation

SI Units Prefixes:

$\begin{array}{llll}\text { a (atto) } & 10^{-18} & \mathrm{k} \text { (kilo) } & 10^{3} \\ \mathrm{f} \text { (femto) } & 10^{-15} & \mathrm{M} \text { (mega) } & 10^{6} \\ \mathrm{p} \text { (pico) } & 10^{-12} & \mathrm{G} \text { (giga) } & 10^{9} \\ \mathrm{n} \text { (nano) } & 10^{-9} & \mathrm{~T} \text { (tera) } & 10^{12} \\ \mathrm{~m} \text { (micro) } & 10^{-6} & \mathrm{P} \text { (peta) } & 10^{15} \\ \mathrm{~m} \text { (milli) } & 10^{-3} & \mathrm{E} \text { (exa) } & 10^{18}\end{array}$

For example, $10^{12} \mathrm{~Bq}$ of radioactivity can be expressed as $1 \mathrm{TBq}$ or one tera becquerel.

SIAE: State Institute of Applied Ecology

Sv: Sievert

SNF: Spent nuclear fuel

SRW: Solid radioactive waste

SS: Stainless steel

STWG: Source-Term Working Group

T: Tissue

TFC: Technical fuel channel

TBq: Terabequerel (1 Bq $\times 10^{12)}$

UNSCEAR: United Nations Scientific Committee on the Effects of Atomic Radiation $\mathrm{W}_{\mathrm{T}}$ : Weighting Factors 



\title{
1. INTRODUCTION
}

\author{
D. Layton, ${ }^{*}$ B. Napier, ${ }^{\dagger}$ L. Gomez ${ }^{* *}, J^{\prime}$ Knezovich, ${ }^{*}$ and M. Varela ${ }^{+\dagger}$
}

*Lawrence Livermore National Laboratory, Livermore, CA

+Battelle Pacific Northwest Laboratories, Richland, WA

${ }^{* *}$ Sandia National Laboratories, Albuquerque, NM

${ }^{+}$Office of Naval Research, Arlington, VA

D isclosures in the early 1990s of the dumping of radioactive wastes directly into the Arctic Ocean by agencies of the former Soviet Union (FSU) raised international concerns about the potential impacts of this dumping. The principal U.S. response to these disclosures, which were documented in a Russian-government report authored by Yablokov et al. (1993), was to fund the Arctic Nuclear Waste Assessment Program (ANWAP) in the Office of Naval Research. This program consists of a broad spectrum of projects ranging from measurement and experimental programs investigating biogeochemical processes in the Arctic Ocean to computer modeling studies examining the movement of water and ice (Morgan and Codispoti, 1995; Edson et al., 1996). Since 1995, one important element of ANWAP has been the preparation of an integrated assessment of the potential risks to Alaskan marine ecosystems and peoples posed by nuclear wastes derived from the FSU. The objective of this effort is to develop and apply a marine radiological assessment methodology that specifically addresses (1) the principal sources of nuclear wastes from the FSU that could impact the Arctic Ocean; (2) the transport of key radionuclides in the Arctic Ocean; (3) bioaccumulation of those radionuclides in marine species; (4) human dietary exposures via the consumption of fish and marine mammals; and (5) absorbed doses and associated risks for marine ecosystems and exposed human populations, with a principal emphasis on Alaskans relying on seafoods as important dietary items.

This is a prospective assessment, not undertaken to address any specific, observed human health or ecological problem in Alaska, but rather to evaluate the potential impacts from the FSU's improper disposal of nuclear materials. Completing such an effort requires a multidisciplinary team of investigators. To appropriately organize its risk-assessment effort, ANWAP in the summer of 1995 formed a Risk Assessment Integration Group (RAIG), a core group of individuals who would interact with other ANWAP investigators to obtain the relevant data and analyses. The RAIG included scientists from Lawrence Livermore National Laboratory, Pacific Northwest National Laboratory, Sandia National Laboratories, the State of Alaska, Department of Environmental Conservation, the North Slope Borough, and the Office of Naval Research (ONR). Concurrent with the initial formulation stages of the risk-assessment framework was ONR's appreciation 
that an important facet of the risk assessment should be communication, particularly with the native community in Alaska. An effort was made to reach out to native health associations, and to scientists and community leaders particularly knowledgeable about resources and dietary practices in North and Northwestern Alaska. In the spring of 1996, RAIG representatives traveled to Anchorage, Barrow, Kotzebue, and Nome to discuss the elements, purpose, and goals of the risk assessment and to ensure that it reflects local knowledge and interests.

\subsection{Nuclear Wastes Addressed}

Figure 1-1 depicts the primary sites of nuclear wastes derived from the FSU that could impact the Arctic seas.

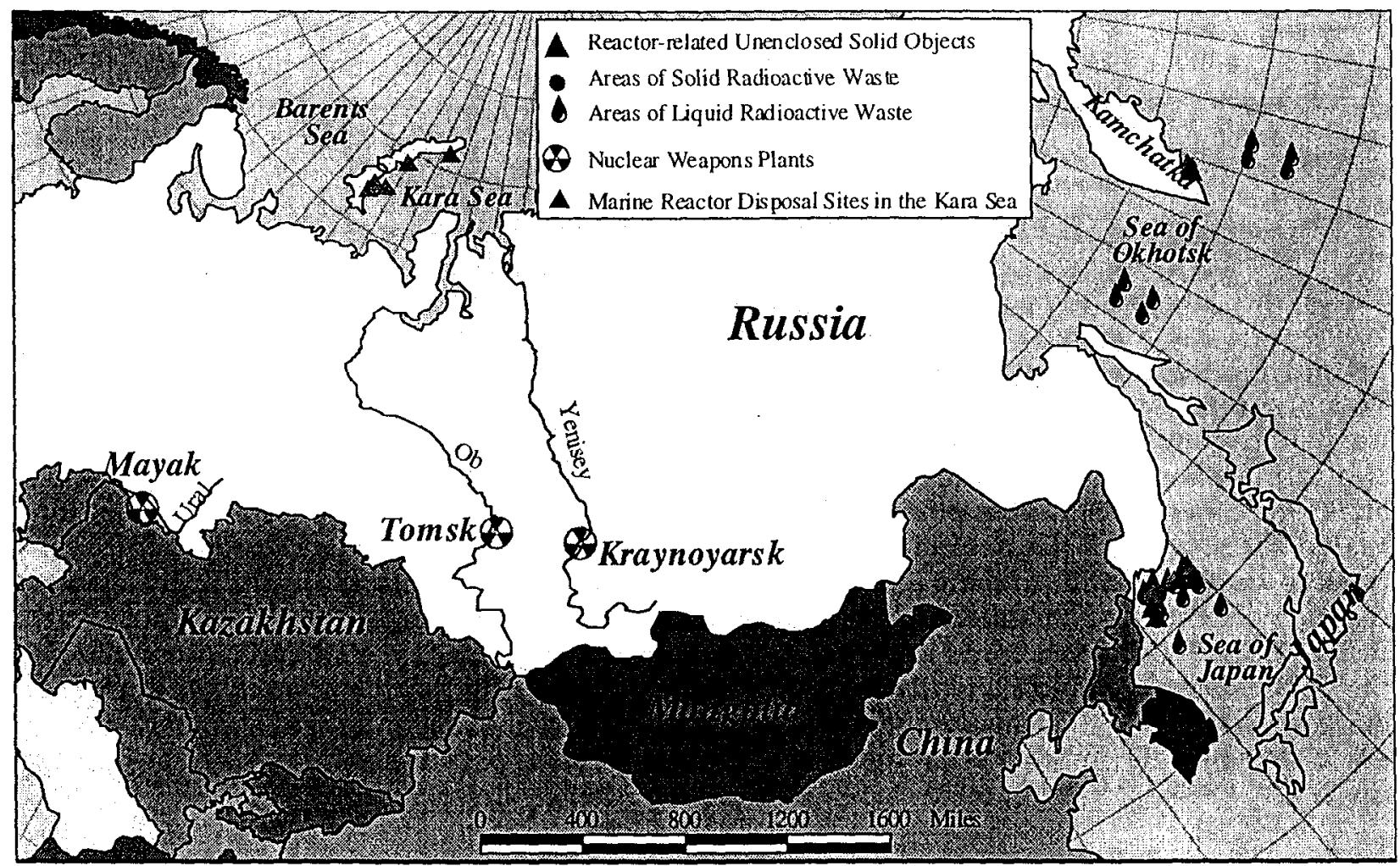

Figure 1-1. Locations of the nuclear wastes of concern derived from the former Soviet Union.

The Kara Sea dump sites located adjacent to Novaya Zemlya have received the most scrutiny because of the amount and type of wastes discarded (including both liquid wastes and reactor vessels with and without radioactive fuel) and their proximity to the productive fisheries in the Barents Sea. The main concern with the reactor compartments and fuels disposed from 1965 to 1988 is the leaching of radionuclides to seawater and subsequent transport elsewhere in the Arctic Ocean. Another set of sites the assessment addresses are nuclear-waste ponds and reservoirs 
at nuclear installations situated next to the $\mathrm{Ob}$ and Yenisey rivers. If any of the waste reservoirs failed and released their radioactive liquids and solids to either river, a portion of the wastes would eventually discharge to the Kara Sea. The final set of wastes addressed are the liquid and solid wastes that were dumped at various locations in the Northwest Pacific Ocean as recently as 1992.

\subsection{Risk-Assessment Methodology}

An integrated assessment of the risk posed by a radionuclide released into the environment includes several distinct components, as shown in Figure 1-2.

The basic foundation of any risk assessment is the source-term characterization of the contaminant(s) being addressed. The basic goals of this component of an assessment are to determine the inventory (e.g., radioactivity or mass) of the contaminants available for release into the environment and to quantify time-varying release rates to the environment.

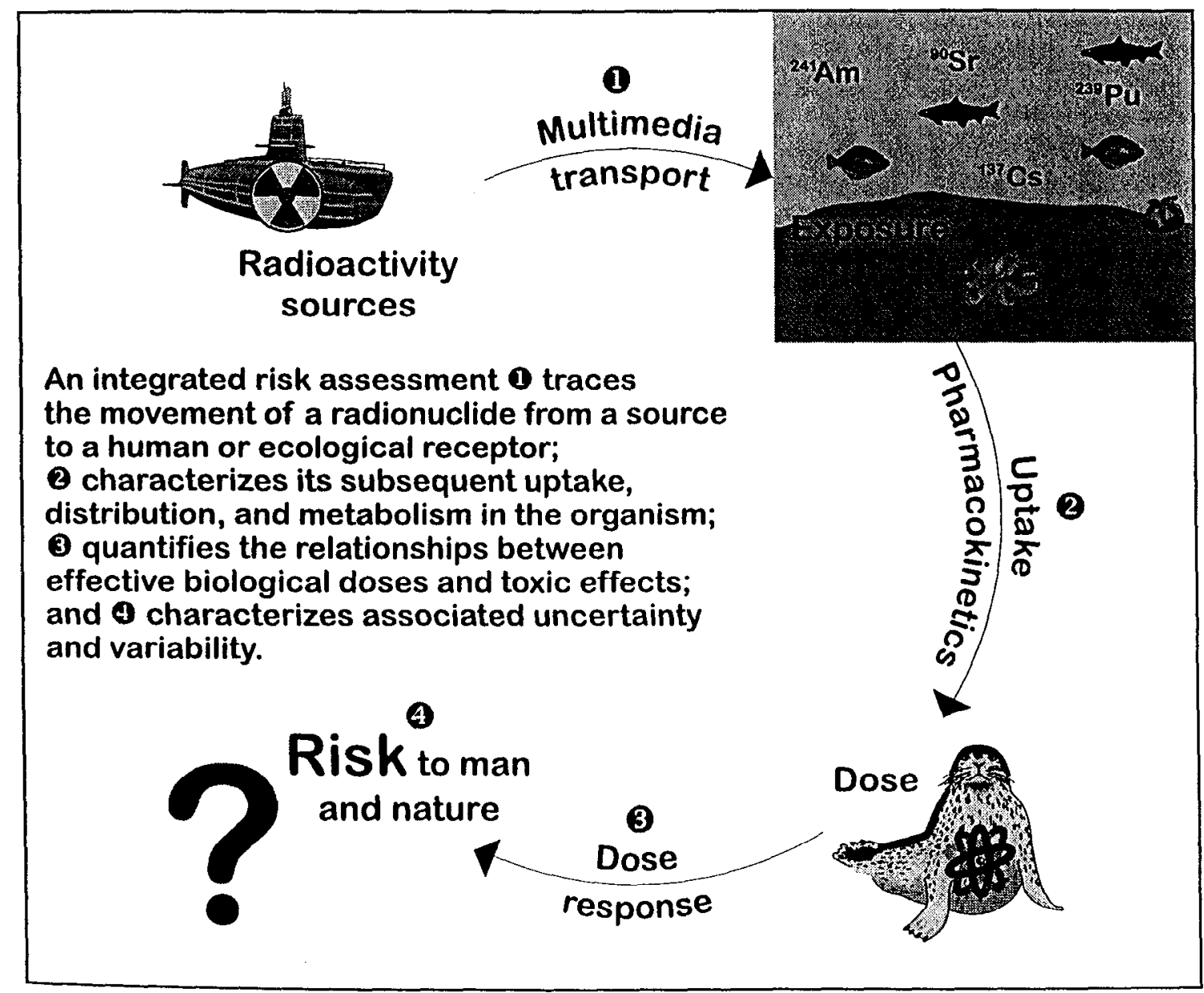

Figure 1-2. Overview of the basic risk-assessment methodology. 
The ANWAP assessment focuses exclusively on direct releases to ocean waters or riverine releases that end up in ocean waters. Next, measurements and/or models help determine the transport and fate of the radionuclides in the environment. An important output of the transport component of the assessment is the prediction of the spatial and temporal distributions of radionuclide concentrations in ocean waters. Once the radionuclide concentrations in environmental media are determined, the RAIG analyzes the mechanisms that bring marine organisms and humans in contact with the contaminants. For humans the dominant pathway of exposure to marine contaminants is the ingestion of seafoods, while for marine organisms pathways include the intake of foods and sediment, immersion, and direct uptake from water. The RAIG translates exposures to a radionuclide to internal doses to body tissues and organs using models that simulate its uptake, distribution, retention, and elimination. Dose-response functions are then used to relate biologically effective doses to toxic endpoints. Finally, sensitivity and uncertainty analyses are performed to guide the interpretation of the predicted risks.

\subsection{SCOPE OF the Risk Assessment}

The risk assessment begins with a characterization of existing and potential sources of radionuclides in the Arctic Ocean and the Northwest Pacific Ocean (Section 2 of this report). As background information, the RAIG discusses both natural and anthropogenic sources of radionuclides in seawater (e.g., radionuclides from the uranium decay chains and nuclear testing and processing facilities). Of special interest is an analysis of the various sources of radionuclides detected in Arctic waters, including nuclear-weapons testing, the Chernobyl accident, and nuclear installations such as the fuel-reprocessing facilities at Sellafield, United Kingdom, and La Hague, France. Following the analysis of previously existing sources of radionuclides, the RAIG reviews information on the inventories of various nuclear wastes dumped by the FSU in ocean waters and stored at inland locations in Russia. Next, the team conducts a screening-level analysis to identify which of the radionuclides from the FSU sources are potentially the most important from a risk standpoint, based on their inventories, transport in Arctic waters, and possible subsequent human exposures and doses. The RAIG then estimates the source-term inputs of the key radionuclides to the Arctic seas from Russian dump sites in the Kara Sea. Estimates of release rates for the wastes at the Kara Sea dump sites rely on models and supporting data from the International Arctic Seas Assessment Project (IASAP), sponsored by the International Atomic Energy Agency (IAEA).

Another source of nuclear waste is radioactive liquid wastes stored in reservoirs and ponds at nuclear-weapons facilities in the Russian interior adjacent to the $\mathrm{Ob}$ and Yenisey rivers. The RAIG summarizes information available on those sources and presents simple release scenarios for subsequent analysis. Finally, FSU agencies dumped solid and liquid nuclear wastes in the Northwest Pacific. Unlike the Kara Sea, however, most of the dumping evidently occurred as liquid wastes, but radioactively contaminated solid wastes also exist on the sea bottom. The team estimates the magnitude of such sources.

Results of the source-term analyses serve as the primary inputs to computer models that simulate the transport of the various radionuclides in the Arctic Ocean (Section 3). The transport models predict the concentrations of radionuclides in the Arctic seas resulting from the simulated releases of radionuclides from the dumpsites in the Kara Sea and liquid-waste disposal sites located within the drainage areas of the Ob and Yenisey rivers. Section 4 is devoted to the development of bioconcentration factors (BCFs) that relate the predicted concentrations of the key radio- 
nuclides dissolved in seawater with the associated levels in fish and marine mammals. Section 5 provides a brief overview of Arctic marine systems and their food webs, primarily emphasizing species of ecological significance and economic importance. The RAIG assesses the potential of radiological effects on marine organisms by comparing dose rates reported to produce significant detrimental effects on mortality, sterility, and fertility in radiosensitive species to those dose rates predicted from the release of FSU-waste radionuclides, using worst-case scenarios, and to those from measured values of anthropogenic and naturally occurring radionuclides.

Section 6 presents the results of the health-risk assessment for Alaskan populations whose diet includes significant amounts of fish and marine mammals derived from the Arctic Ocean. Because the dietary habits of native populations vary considerably, the RAIG has developed two different approaches for estimating dietary exposures to radionuclides. The first approach defines reference diets that reflect the food intakes typical of people living in Alaskan coastal villages. The team then uses these reference intakes with measured or estimated concentrations of radionuclides in the individual dietary items and with appropriate dose-conversion factors to estimate radiation doses. As an alternative, it presents a technique for constructing an individual's personal dietary dose using information on the average daily intakes of seafoods and unit doseconversion factors for the seafoods (i.e., radiation dose incurred from consuming a specified amount of a given seafood item each year). 


\title{
2. Source-Term Analyses of Potential Radionuclide Releases Relevant to the Arctic Seas and Northwest Pacific Ocean
}

\author{
M. Mount, ${ }^{*}$ D. Layton, ${ }^{*}$ L. Hibler, ${ }^{\dagger}$ P. Becker, ${ }^{\dagger}$ B. Napier, ${ }^{\dagger}$ and W. Templeton ${ }^{\dagger}$
}

*Lawrence Livermore National Laboratory, Livermore, CA

tPacific Northwest National Laboratory, Richland, WA

$\mathrm{D}$ uring the years 1960 to 1993, the FSU was responsible for the disposal of radioactive wastes into the Kara Sea; the Barents Sea; Sea of Japan; Sea of Okhotsk; the Pacific Ocean, east coast of Kamchatka; and the West Siberian Basin near the Ob and Yenisey Rivers. These releases came from several marine- and land-based sources. In 1993, the Russian report, Facts and Problems Related to Radioactive Waste Disposal in Seas Adjacent to the Territory of the Russian Federation (Yablokov et al., 1993), was released, presenting the findings presented of an October 1992 scientific study commissioned by the Office of the President of the Russian Federation. Related to the Arctic and Northwest Pacific Ocean areas, the White Book, as the report was later called, reported the following incidents:

(1) Between 1965 and 1988, 16 marine reactors from seven FSU submarines and the icebreaker Lenin, each of which suffered some form of reactor accident, were dumped at five sites in the Kara Sea. Six of the 16 reactors contained their spent nuclear fuel (SNF);

(2) Between 1960 and 1991, low-level liquid radioactive waste (LRW) was discharged at sites in the White, Barents, and Kara seas;

(3) Between 1964 and 1991, low- and intermediate-level solid radioactive waste (SRW) was dumped at sites in the Barents and Kara seas;

(4) Ten separate disposal sites were reported in the seas adjacent to the Russian Far East: six in the Sea of Japan, one in the Sea of Okhotsk, and three in the Pacific Ocean, east coast of Kamchatka.

The White Book rarely identified specific radionuclides and provided no estimates of the current levels of radioactivity or radionuclide releases to the environment. Supplementing the information presented in the White Book, Bradley and Jenquin (1995) have provided important information on the nuclear inventories for major nuclear-waste sites within the West Siberian Basin. The 
primary sources of nuclear wastes in the Basin are the nuclear-weapons plants at Mayak, Tomsk 7, and Krasnoyarsk 26, and the nuclear weapons test site at Semipalatinsk. Each of the three weapons-production sites have nuclear reactors and related facilities for producing and processing plutonium $\left({ }^{239} \mathrm{Pu}\right)$ for nuclear weapons. Nuclear materials from these sites already have contaminated rivers that flow into the Kara Sea, and existing LRW stored at the various locations constitute a future threat to the river, and to the Arctic Ocean.

To assess the potential risks of these nuclear-waste sources, the RAIG must quantify the timevarying or instantaneous release of environmental radionuclides from a given source (e.g., a submerged reactor vessel or waste pond) to a transport medium (e.g., the Kara Sea or the Ob River). A source-term analysis has three principal components: (1) estimation of the total inventories (i.e., radioactivity) of radionuclides present in a given source; (2) selection of the most important nuclides for subsequent analysis; and (3) prediction of radionuclide releases from a given source to the environment. The RAIG begins the source-term analysis with an overview of waste sources, the identification of radionuclides in the waste sources, and the estimation of the amounts of radioactivity associated with the various nuclides. Because many nuclides are associated with the various sources, the RAIG conducts screening-level analyses to determine which nuclides are potentially most important from a radiological standpoint. Screening analyses incorporate information on parameters involving the estimated inventories, the half-lives for radioactive decay, mobility in the environment, and dose to provide a semi-quantitative ranking of nuclides. Once the key radionuclides are defined, the third phase of a source-term analysis begins: the estimation of continuous or discrete releases of the radionuclides to the environment. Various release scenarios are evaluated to bound the kinds of release mechanisms that could occur over time, for example, chronic releases that result from the corrosion and dissolution of reactor fuels or a catastrophic release caused by some external event.

This section summarizes the FSU disposal sites, radionuclide inventories, and potential release scenarios for sites in the Kara Sea; Sea of Japan; Sea of Okhotsk; the Pacific Ocean, cast coast of Kamchatka; and the West Siberian Basin. The RAIG begins, however, with an overview of existing sources of radionuclides in Arctic waters to establish the basis for later comparisons with the FSU sources.

\subsection{Existing Sources of Radionuclides in Arctic Waters}

Radionuclides in the Arctic Ocean include those from natural sources (e.g., primordial nuclides such as potassium $\left({ }^{40} \mathrm{~K}\right)$ and uranium $\left({ }^{238} \mathrm{U}\right)$ together with its radioactive progeny) and nuclides derived from anthropogenic sources. From a radiological dose standpoint, the most important naturally occurring radionuclide in seawater is polonium $\left({ }^{210} \mathrm{Po}\right)$, an alpha-emitting radionuclide in the ${ }^{238} \mathrm{U}$ decay chain that has a half-life of 140 days (see Noshkin et al., 1994, Aarkrog et al., 1997). This radionuclide is ubiquitous in seawater and seafoods worldwide. The primary anthropogenic sources of radionuclides in Arctic waters include (1) nuclear fuel reprocessing facilities in Europe at Sellafield, United Kingdom, and La Hague, France; (2) global fallout from aboveground nuclear-weapons testing in the 1950s and 1960s); (3) liquid-waste discharges from Russian nuclear installations on the $\mathrm{Ob}$ and Yenisey rivers; and (4) the Chernobyl nuclear reactor accident. The principal nuclides of interest from such sources are fission products and actinides. 
To put the various anthropogenic sources in perspective, Aarkrog (1994) estimated the contributions of these sources to the total inventories of cesium $\left({ }^{137} \mathrm{Cs}\right)$ and strontium $\left({ }^{90} \mathrm{Sr}\right)$ in Arctic waters (excluding radionuclides present in waste sites in the Kara Sea), as shown in Table 2-1.

Table 2-1. Estimated inventories of ${ }^{137} \mathrm{Cs}$ and ${ }^{90} \mathrm{Sr}$ in the Arctic Ocean from various sources (excluding ${ }^{137} \mathrm{Cs}$ in Kara Sea waste sites) (Aarkrog, 1994).

\begin{tabular}{|c|c|c|}
\hline \multirow[t]{2}{*}{ Source } & \multicolumn{2}{|c|}{ Activity, $\mathrm{PBq}$} \\
\hline & $90 \mathrm{Sr}$ & ${ }^{137} \mathrm{Cs}$ \\
\hline Global fallouta & 4.1 & 4.6 \\
\hline Sellafield discharges & $1-2$ & $10-15$ \\
\hline Riverine discharges from the former Soviet Union & $1-5$ & $1-5$ \\
\hline Chernobyl reactor accident & 0 & $1-5$ \\
\hline Total & $6-11$ & $17-30$ \\
\hline
\end{tabular}

ancluding runoff from land.

The dominant source of ${ }^{137} \mathrm{Cs}$ is the reprocessing facility at Sellafield, whereas for ${ }^{90} \mathrm{Sr}$, worldwide fallout is the primary source. Kershaw and Baxter (1995) have provided a detailed review of radionuclide releases from Sellafield and their subsequent transfer to the Arctic Ocean. They report that a total of $41 \mathrm{PBq}$ (i.e., $41 \times 10^{15} \mathrm{~Bq}$ ) of ${ }^{137} \mathrm{Cs}$ was discharged to the Irish Sea through 1992. Discharges from the site have fluctuated markedly over time, with peak releases for ${ }^{137} \mathrm{Cs}$ and other nuclides occurring in the 1970s. Changes in operations and control measures since that time have resulted in a significant decline in discharges (Gray et al., 1995). For comparison, the La Hague facility has released significantly less ${ }^{137} \mathrm{Cs}$ and ${ }^{90} \mathrm{Sr}$ than Sellafield (i.e., 2.3 and 1.2\%, respectively, of the 41 and $6.2 \mathrm{PBq}$ discharges of ${ }^{137} \mathrm{Cs}$ and ${ }^{90} \mathrm{Sr}$ from Sellafield; see Herrmann et al., 1995).

Many studies have dealt with the transport pathway of the soluble nuclides discharged from Sellafield to the Arctic, summarized by Kershaw and Baxter (1995), who indicate that the basic transport pathway of the released radionuclides follows this scheme: Irish Sea to North Sea via the North Channel, and North Sea to Norwegian Sea via the Norwegian Coastal Current where the plume divides into two parts, one leading to the Barents Sea and the other to the central portion of the Arctic Basin. Estimates of the transit time from Sellafield to the Arctic Ocean range from 4 to 6 years (Kershaw and Baxter, 1995). Based on measured concentrations of ${ }^{137} \mathrm{Cs}$ in ocean currents entering the Barents Sea, flow rates of the currents, and the transit time noted above, they estimate that $22 \%( \pm 6 \%)$ of the ${ }^{137} \mathrm{Cs}$ released from Sellafield reaches the Barents Sea as it moves toward the central Arctic Ocean. This transfer factor produces an estimated input of $9 \mathrm{PBq}$ through 1993 (i.e., $0.22 \times 41 \mathrm{PBq}$ ). They note, however, that this may represent a "considerable underestimate" of the actual input because of limited data on the entire concentration profile of Sellafield-derived ${ }^{137} \mathrm{Cs}$ in ocean currents entering the Barents Sea. 
Releases of ${ }^{239,240} \mathrm{Pu}$ from Sellafield have also reached Arctic waters, based on an analysis of the ratios of ${ }^{238} \mathrm{Pu} /{ }^{239,240} \mathrm{Pu}$, which can be used to distinguish between $\mathrm{Pu}$ derived from nuclear-fuel reprocessing facilities and from worldwide fallout (Holm et al., 1986). Specifically, the average ${ }^{238} \mathrm{Pu} /{ }^{239,240} \mathrm{Pu}$ ratio for the Sellafield facility is 0.31 , while for global fallout the ratio is about 0.035 (Hallstadius et al., 1986). About $90 \%$ of the $590 \mathrm{TBq}$ (i.e., $590 \times 10^{12} \mathrm{~Bq}$ ) of ${ }^{239,240} \mathrm{Pu}$ released since 1952 from Sellafield is estimated to reside in the sediments of the Irish Sea (Kershaw et al., 1995). Only about $4 \%$ of the Pu released is in soluble form, and Holm et al. (1986) estimated that $80 \%$ of that amount is removed by sedimentation prior to entering the Barents and Greenland Seas. Thus, nearly $20 \mathrm{TBq}$ of ${ }^{239,240} \mathrm{Pu}$ has reached the Arctic Ocean from Sellafield, and according to Holm et al., the resulting concentrations of ${ }^{239,240} \mathrm{Pu}$ in seawater are $0.6-.4 \mathrm{mBq} / \mathrm{m}^{3}$ (or $5-10 \%$ of the measured levels in the early 1980s). Baskaran et al. (1995) analyzed data on the concentrations of ${ }^{238} \mathrm{Pu}$ and ${ }^{239,240} \mathrm{Pu}$ in sediment samples from the Kara Sea and determined that ${ }^{238} \mathrm{Pu} /{ }^{239,240} \mathrm{Pu}$ ratio for the samples equals $0.034 \pm 0.003$. This ratio is very close to the ratio of these Pu isotopes in worldwide fallout (i.e., 0.035), which suggests that fuel reprocessing facilities have contrib-

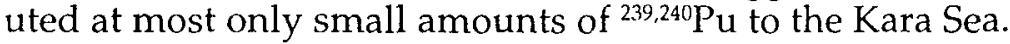

Other nuclides of potential interest include americum $\left({ }^{241} \mathrm{Am}\right)$, technetium $\left({ }^{99} \mathrm{Tc}\right)$, iodine $\left({ }^{129} \mathrm{I}\right)$, and antimony $\left({ }^{125} \mathrm{Sb}\right)$. I Iallstadius et al. (1986) have reviewed data on the seawater concentrations of

${ }^{241} \mathrm{Pu}$ and ${ }^{241} \mathrm{Am}$, which is produced from the decay of ${ }^{241} \mathrm{Pu}$, concluding that radioactive decay of fallout ${ }^{241} \mathrm{Pu}$, rather than reprocessing wastes, accounts for most of the ${ }^{241} \mathrm{Am}$ in Arctic waters. This is consistent with the fact that $\mathrm{Am}$ is more particle-reactive than $\mathrm{Pu}$, and one would therefore expect that Am adsorption to river sediment (scavenging) would reduce greatly the amounts of Am reaching Arctic waters. Few data are available on ${ }^{99} \mathrm{Tc}$; Kershaw and Baxter (1995), however, suggested that this radionuclide has entered the Arctic Basin because of its long half-life and limited adsorption to suspended sediments. Measurements of ${ }^{129} \mathrm{I}$ within the Canadian Arctic Basin and the western Arctic in 1993/1994 have been reported by Kilius et al. (1995) and Beasley et al. (1995). Raisbeck et al. (1995) indicated that about $85 \%$ of the ${ }^{129}$ I released to the North Sea is transferred to the Arctic Seas, and Yiou et al. (1995) estimated that about $90 \%$ of the ${ }^{129} \mathrm{I}$ discharged is from La Hague. La Hague has produced about 20 times more ${ }^{125} \mathrm{Sb}$ than Sellafield (Herrmann ct al., 1995). Guegueniat et al. (1995) estimate that levels of ${ }^{125} \mathrm{Sb}$ in the Barents Sea that are attributable to La Hague range between 0.10 and $0.15 \mathrm{~Bq} / \mathrm{m}^{3}$.

\subsection{Description of Marine Disposal Sites}

\subsubsection{Kara Sea Marine Nuclear Reactors}

Of the discarded marine nuclear reactors, six of the 16 contained their SNF. In addition, approximately $60 \%$ of the SNF from one of the three icebreaker reactors was disposed of in a reinforced concrete and stainless steel (SS) shell container. The vast majority of the low- and intermediatelevel SRW was disposed of in containers of unknown composition. The Kara Sea disposal sites for the 16 marine reactors and low- and intermediate-level SRW varied in depth from 12 to $380 \mathrm{~m}$. In particular, the icebreaker reactors and part of their SNE, the single largest source of radioactivity, were reportedly disposed of in Tsivolka Fjord at an estimated depth of $50 \mathrm{~m}$. Figure 2-1 shows a map of Novaya Zemlya with the approximate locations of the five disposal sites. 


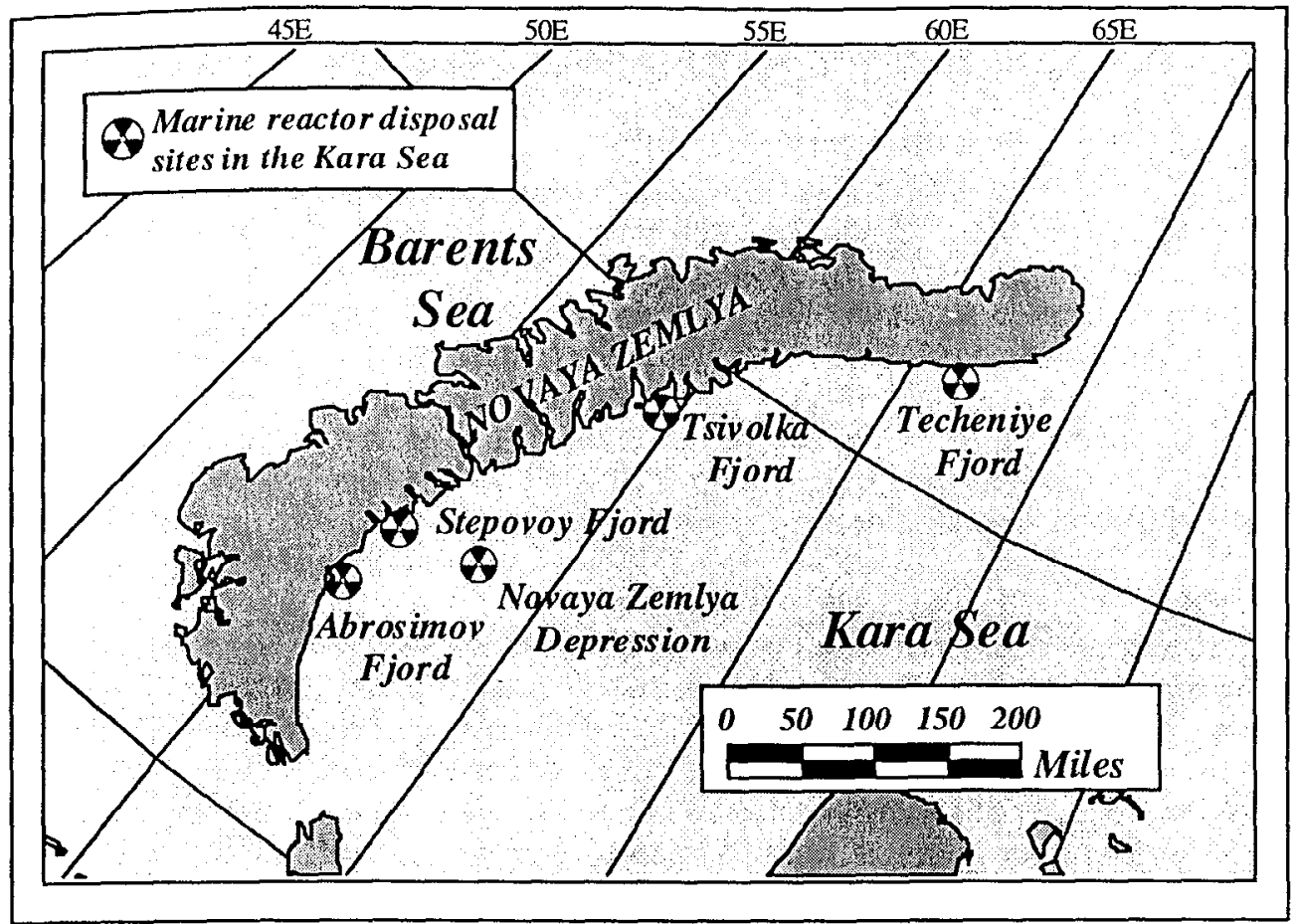

Figure 2-1. A map of Novaya Zemlya showing locations of the disposal sites.

Table 2-2 shows disposal information for the marine reactors dumped in the Kara Sea. IAEA (1997) presents details of the nuclear reactors and their disposal.

\section{Submarine Pressurized Water Reactors}

\section{Accident}

Six of the seven nuclear submarines contained two pressurized water reactors (PWRs) each. Eleven of these PWRs were dumped into the Kara Sea between 1965 and 1988: eight with and threc without their reactor compartments (RCs). All these nuclear submarines suffered some form of reactor accident; however, many specifics of the reactor design, maximum thermal power, compartment layout, detailed operating histories, and accident scenarios remain classified. A criticality accident aboard submarine factory number 421 is known to have caused over-pressurization of the right-board reactor pressure vessel (RPV). The fuel rods were reportedly undamaged; however, a decision was made to nol reuse the RPV. As such, the SNF was not removed (Sivintsev, August 1994, March 1995, September 1995, and December 1995).

\section{Disposal}

With the exception of the right-board RPV from submarine factory number 421 and the two PWRs from submarine factory number 538, all PWRs were dumped in their separated RCs. The SNF was removed from the left-board RPV of submarine factory number 285 and both RPVs of submarine factory numbers 254,260 , and 538 . The SNF remained in the right-board RPV of subma- 


\begin{tabular}{|c|c|c|c|c|c|c|c|c|c|}
\hline & & & & & & Number of Rea & ctors & Total Activi & $(\mathrm{PBq})$ \\
\hline $\begin{array}{l}\text { Disposal } \\
\text { Site }\end{array}$ & $\begin{array}{l}\text { Year of } \\
\text { Disposal }\end{array}$ & $\begin{array}{l}\text { Factory } \\
\text { Number }\end{array}$ & $\begin{array}{l}\text { Dumped } \\
\text { Unit }\end{array}$ & $\begin{array}{l}\text { Disposal } \\
\text { Coordinates } 1\end{array}$ & $\begin{array}{l}\text { Disposal } \\
\operatorname{Depth}^{2}(\mathrm{~m})\end{array}$ & $\begin{array}{l}\text { Without Spent } \\
\text { Nuclear Fucl }\end{array}$ & $\begin{array}{l}\text { With Spent } \\
\text { Nuclear Fuel }\end{array}$ & $\begin{array}{l}\text { At the Time } \\
\text { of Disposal }\end{array}$ & 1994 \\
\hline \multirow[t]{4}{*}{$\begin{array}{l}\text { Abrosimov } \\
\text { Fjord }\end{array}$} & 1965 & 901 & $\begin{array}{l}\text { Reactor } \\
\text { compartment }\end{array}$ & $\begin{array}{l}71^{\circ} 56.03^{\prime} \mathrm{N} \\
55^{\circ} 18.15^{\prime} \mathrm{E}\end{array}$ & $20(10-15)$ & - & 2 & 3.0 & 0.73 \\
\hline & & 285 & $\begin{array}{l}\text { Reactor } \\
\text { compartment }\end{array}$ & $\begin{array}{l}71^{\circ} 56.03^{\prime} \mathrm{N} \\
55^{\circ} 18.08^{\prime} \mathrm{E}\end{array}$ & $20(10-15)$ & 1 & 1 & 12 & 0.66 \\
\hline & & 254 & $\begin{array}{l}\text { Reactor } \\
\text { compartment }\end{array}$ & $\begin{array}{l}71^{\circ} 55.22^{\prime} \mathrm{N} \\
55^{\circ} 32.54 \mathrm{E}\end{array}$ & 20 & 2 & - & 0.093 & 0.009 \\
\hline & 1966 & 260 & $\begin{array}{l}\text { Reactor } \\
\text { compartment }\end{array}$ & $\begin{array}{l}71^{\circ} 56.03^{\prime} \mathrm{N} \\
55^{\circ} 18.08^{\prime} \mathrm{E}\end{array}$ & 20 & 2 & - & 0.044 & 0.005 \\
\hline $\begin{array}{l}\text { Tsivolka } \\
\text { Fjord }\end{array}$ & 1967 & OK-150 & $\begin{array}{l}\text { Reactor } \\
\text { compartment } \\
\text { and special } \\
\text { container with }\end{array}$ & $\begin{array}{l}74^{\circ} 26.10^{\prime} \mathrm{N} \\
58^{\circ} 36.15^{\prime} \mathrm{E} \\
\text { fuel }\end{array}$ & 50 & 3 & $0.6^{3}$ & 20 & 2.2 \\
\hline $\begin{array}{l}\text { Novaya } \\
\text { Zemlya } \\
\text { Depression }\end{array}$ & 1972 & 421 & $\begin{array}{l}\text { Reactor } \\
58^{\circ} 10^{\prime} \mathrm{E}\end{array}$ & $72^{\circ} 40^{\prime} \mathrm{N}$ & 300 & - & 1 & 1 & 0.29 \\
\hline $\begin{array}{l}\text { Stepovoy } \\
\text { Fjord }\end{array}$ & 1981 & 601 & Submarine & $\begin{array}{l}72^{\circ} 31.25^{\prime} \mathrm{N} \\
55^{\circ} 30.25^{\prime} \mathrm{E}\end{array}$ & $50(30)$ & - & 2 & 1.7 & 0.84 \\
\hline $\begin{array}{l}\text { Techeniye } \\
\text { Fjord }\end{array}$ & 1988 & 538 & Reactors & $\begin{array}{l}73^{\circ} 59^{\prime} \mathrm{N} \\
66^{\circ} 18^{\prime} \mathrm{E}\end{array}$ & $35-40$ & 2 & - & 0.006 & 0.005 \\
\hline Total & & & & & & 10 & 6.6 & 37 & 4.7 \\
\hline
\end{tabular}

1 Disposal site coordinates for all units except those from factory number OK-150 are from Yablokov et al., 1993. Disposal site coordinates for the OK-150 units are from reference Sivintsev, September 1995.

2 The disposal depths were provided in May 1993 by the Russian Federation; those in parenthesis were obtained during joint Norwegian-Russian scientific cruises in 1993 and 1994.

3 Thermal shields, hardware, and approximately $60 \%$ of SNF discarded in special container. 
rine factory number 285 , the right-board RPV of submarine factory number 421, and both RPVs of submarine factory number 901 (Sivintsev, August 1994, March 1995, September 1995, and December 1995).

Before disposal, the primary circuit loops and equipment of all PWRs were washed, dried, and sealed. However, there is no indication that the seals were hermetic. Those RPVs containing SNF were filled with Furfurol $(\mathrm{F})$, a hardening compound based on furfural, prior to disposal. Before filling each RPV with Furfurol (F), 28 of the 30 control or compensation rod (CCR) guide tubes were sealed and a 1.5-mm diameter hole was drilled through the upper wall of one. During filling, the RPV was heated, one unsealed CCR guide tube was used as the inlet, the other was used as the outlet, and air was withdrawn through the $1.5-\mathrm{mm}$ diameter hole. Once the process was completed, the 1.5-mm diameter hole was to be capped. However, since the capping of this hole cannot be confirmed, for modeling purposes the hole is assumed to be open to allow ingress of water to the Furfurol $(F)$.

The shallow waters of Abrosimov Fjord were used for four separate disposal operations. Separated RCs from submarine factory numbers 901,285 , and 254 were dumped in 1965 at estimated depths of $50 \mathrm{~m}$ (Sivintsev, September 1995), $20 \mathrm{~m}$ (Yablokov et al., 1993, and Sivintsev, September 1995), and $20 \mathrm{~m}$ (Yablokov et al., 1993), respectively. In 1966, the separated RC from submarine factory number 260 was also dumped at an estimated depth of $20 \mathrm{~m}$ (Yablokov et al., 1993). At the time of disposal, the RCs were allowed to flood, thereby exposing a significant portion of the external surface of each RPV and the cavities and internal constructions of those RPVs without SNF to seawater. As such, seawater is assumed to have been within the left-board RPV of submarine factory number 285, and both RPVs of submarine factory numbers 254 and 260 for 30, 30, and 29 years, respectively. The right-board RPV, with its SNF, was removed from the RC of submarine factory number 421, placed into a steel collar-like support structure within the hull of a barge, and covered with concrete. The concrete layer above the RPV lid was about $200-\mathrm{mm}$ thick. The concrete between the outer surface of the RPV wall and the inner surface of the barge hull was no less than 800-mm thick. In 1972, the barge containing the right-board RPV of submarine factory number 421 was dumped in the Novaya Zemlya Depression at an estimated depth of $300 \mathrm{~m}$ (Yablokov et al., 1993; Sivintsev, September 1995).

Both RPVs of submarine factory number 538 and their associated steam generators (SGs) and primary circuit pumps, were removed from the $\mathrm{RC}$ of the submarine and placed into a steel collar-like support structure within the hull of a barge. The RPV lids and all penetrations into the lids were sealed by welding. No other protective barriers were provided. The barge containing both RPVs, their associated SGs, and their associated primary circuit pumps was sunk in the shallow waters of Techeniye Fjord in 1988 at an estimated depth of 35-40 m (Yablokov et al., 1993). The external surfaces, cavities, and internal constructions of each RPV are assumed to have been exposed to seawater since the time of disposal, a period of about 17 years.

\section{Submarine Liquid Metal Reactors}

\section{Accident}

The remaining nuclear submarine, designated as factory number 601, contained two liquid metal reactors (LMRs) of $70 \mathrm{MW}$ maximum thermal power each and used $\mathrm{Pb}-\mathrm{Bi}$ as the coolant or heat transfer medium. The steam-generating installation (SGI) began operation in December 1962 and operated successfully for the duration of the first core load. Both reactors were reloaded in Sep- 
tember 1967 and operated at 10\% of full power until May 24, 1968, when a portion of the leftboard reactor core channels became blocked while the submarine was at sea. As a consequence, about $20 \%$ of the left-board reactor fuel was destroyed and deposited in the associated SG and volume compensator via the sealed primary circuit. The submarine subsequently returned to base on power from the right-board reactor, shut down, and was sealed on or about June 6, 1968 (Yefimov, 1994 and March 1995).

\section{Disposal}

The SNF remained in the two LMRs of submarine factory number 601. A number of actions were taken to secure the LMRs and prepare the RC for disposal. The primary means was the use of about $2 \mathrm{~m}^{3}$ of Furfurol (F) and $250 \mathrm{~m}^{3}$ of bitumen. In September 1981, over 13 years after the reactor accident, submarine factory number 601 was sunk in the shallow waters of Stepovoy Fjord at an estimated depth of $50 \mathrm{~m}$ (Yablokov et al., 1993). At the time of her sinking, the hatches of the RC were open. As such, seawater has been in the compartment above the bitumen filler for over 14 years (Sivintsev, December 1995; Yefimov, 1994, March 1995).

\section{Icebreaker Pressurized Water Reactors}

\section{Accident}

Launched in Leningrad in 1959, the icebreaker Lenin was the first nuclear merchant ship in the world. During 31 years in commission, the icebreaker had two SGIs. The first SGI contained three PWRs of 90 MW maximum thermal power each and operated from 1959 to February 1965, when during routine repair of the SGI, an operator error allowed the core of the center line (N2) PWR to be left without water for some period of time. As a consequence, a part of the reactor core was damaged because of residual heat. It is this first SGI that forms the basis for the icebreaker source term (Sivintsev, December 1993 and December 1995).

\section{Disposal}

Reactor Compartment. All SNF and the core barrel from the N2 reactor were removed from the three RPVs. Before disposal, the primary circuit loops and equipment were washed, dried, and sealed, and the ceiling of the RC was equipped with special pressure relief valves. The icebreaker, with the RC aboard, was towed from Murmansk to Tsivolka Fjord for the disposal operations. On September 19, 1967, the RC with three RPVs was dumped in the shallow water of Tsivolka Fjord at an estimated depth of $60 \mathrm{~m}$ directly from the icebreaker through the bottom of the hull. The disposal site was approximately $1 \mathrm{~km}$ from the site that was used for the damaged SNF and core barrel from the N2 RPV (Sivintsev, December 1993, March 1995, and September 1995).

Core Barrel and Spent Nuclear Fuel. As a consequence of the accident, only 94 of the 219 technical fuel channels (TFCs) from the N2 RPV could be disposed of in a normal manner. The remaining 125 TFCs and the core barrel from the N2 RPV, hereafter known as Configuration A, were placed within a reinforced concrete and SS shell container, hereafter known as Container $B$. The voids within the cavity of Container $B$ were filled with Furfurol $(F)$, and the lid was secured by welding. Once sealed, Container B was then moved to a temporary land storage facility constructed of concrete blocks. After about 18 months, Container B was removed from the temporary 
storage facility and placed in a specially prepared caisson, hereafter known as Container C, aboard a $6.5-\mathrm{m}$ diameter by $12.5-\mathrm{m}$ long steel pontoon. The walls and lid of Container $\mathrm{C}$ were constructed of SS. The voids between Container B and the interior confines of Container $C$ were filled with Furfurol $(\mathrm{F})$, and the lid was secured by welding. Like the icebreaker, the pontoon was towed from Murmansk to Tsivolka Fjord for disposal. During transit, a storm occurred in the region of the Kara Gate and the pontoon was temporarily lost because the towing cable ruptured. The pontoon was subsequently found, secured to the towing vessel Lepse, and towed to Tsivolka Fjord. On September 18, 1967, the pontoon was dumped within $1 \mathrm{~km}$ of the site that would be used for the RC (Sivintsev, December 1993, March 1995, and September 1995).

\subsubsection{Sea of Japan; Sea of Okhotsk; Pacific Ocean, East Coast of
Kamchatka}

The White Book (Yablokov et al., 1993) also reported a number of findings with respect to radioactive waste disposal in the seas adjacent to the Russian Far East. Overall, there were 10 separate disposal sites: six in the Sea of Japan, one in the Sea of Okhotsk, and three in the Pacific Ocean, east coast of Kamchatka. Again, like the information reported for the northern seas, the radionuclides were not identified and there was no estimate provided for the current levels of radioactivity or radionuclide release to the environment. Two accidental incidents have occurred that add to the level of radioactive contamination present in the seas adjacent to the Russian Far East: one in the Chazhma Bay, Sea of Japan and one in the Sea of Okhotsk.

\section{Sea of Japan}

\section{Accident}

On August 10, 1985, a radiation accident occurred aboard a nuclear submarine during refueling at the Pacific Fleet support facility in Chazhma Bay (Yablokov et al., 1993). An uncontrolled chain reaction is reported to have occurred in the left-board reactor. The resulting thermal explosion led to ejection of a fuel assembly from the reactor, a fire in the $\mathrm{RC}$, and the loss of 10 lives. Damage to the submarine included a hole in the pressure hull in the aft section of the $\mathrm{RC}$, which allowed radioactive water to enter and contaminate the seawater. Immediate atmospheric fallout of radionuclides following the explosion was reported to cover an area within a radius of 50 to $100 \mathrm{~m}$ around the submarine. Later, the fallout of aerosol particles were reported to cover seawater for a distance of up to $30 \mathrm{~km}$ from the accident site. The radionuclide release to the atmosphere was calculated at about $270,000 \mathrm{TBq}$, of which about $81,000 \mathrm{TBq}$ were noble gases. Furthermore, of the total radionuclide release, the ${ }^{137} \mathrm{Cs}$ and ${ }^{90} \mathrm{Sr}$ fission product inventories were calculated to be 1.9 $\mathrm{MBq}$ (i.e., $1.9 \times 10^{6} \mathrm{~Bq}$ ) and $1.5 \mathrm{GBq}$ (i.e., $1.5 \times 10^{9} \mathrm{~Bq}$ ), respectively (Soyfer, 1995).

\section{Disposal}

The Sea of Japan disposal sites (designated as Areas 1, 2, 5, 6, 9, and 10) varied in depth from 1.1 to $3.7 \mathrm{~km}$ and were used for the disposal of both LRW and SRW. At the time of the preparation of the White Book, the characteristics of the LRW were: (1) disposal dates between 1966 and 1992, (2) a total activity at the time of disposal of about $440 \mathrm{TBq}$ of unspecified origin, and (3) a total volume of $82,892 \mathrm{~m}^{3}$. The characteristics of the SRW were: (1) disposal dates between 1968 and 
1992 (2) a total activity at the time of disposal of about $170 \mathrm{TBq}$ of unspecified origin, and (3) a total volume of $18,753 \mathrm{~m}^{3}$ within 5,332 containers, 35 ships, and 40 unenclosed objects.

Since the publication of the White Book, LRW was dumped again in Area 9 on October 17, 1993 (Danilyan and Vysotsky, 1995). The disposal reportedly covered a depth that varied from the surface to $2 \mathrm{~m}$ and an area $48 \mathrm{~km}$ long and 200-400 $\mathrm{m}$ wide. The total activity released to the sea was $0.014 \mathrm{TBq}$ and consisted of ${ }^{137} \mathrm{Cs}(76 \%),{ }^{90} \mathrm{Sr}(21 \%),{ }^{60} \mathrm{Co}(1.5 \%)$, and ${ }^{134} \mathrm{Cs}(1.5 \%)$. Calculations of the dispersal of the radioactivity performed subsequent to the disposal operations indicated that background concentrations were reached within 15-25 hours after disposal. Table 2-3 presents a detailed summary of the pertinent disposal information contained in the White Book for the LRW and SRW dumped in the Sea of Japan, including the disposal-site coordinates.

\section{Sea of Okhotsk}

\section{Accident}

A $13,000-\mathrm{TBq}{ }^{90} \mathrm{Sr}$ radioisotope thermoelectric generator (RTG), a power source of the type used to power a remote lighthouse, was reported lost at sea during a helicopter transport operation near the Sakhalin Island coast in 1987 (Yablokov et al., 1993). No other specifics of the accident or general construction of the RTG are available. 
Table 2-3. Pertinent disposal information for the liquid and solid radioactive waste dumped in the Sea of Japan, as presented in the White Book (Yablokov et al., 1993).

\begin{tabular}{|c|c|c|c|c|c|c|c|c|c|c|c|}
\hline \multirow[b]{3}{*}{$\begin{array}{l}\text { Site } \\
\text { Designation }\end{array}$} & \multirow{2}{*}{\multicolumn{2}{|c|}{ Site Coordinates }} & \multirow[b]{3}{*}{$\begin{array}{l}\text { Disposal } \\
\text { Depth }(\mathrm{km})\end{array}$} & \multirow[b]{3}{*}{ Time Period } & \multirow{2}{*}{\multicolumn{2}{|c|}{ Liquid Waste }} & \multicolumn{5}{|c|}{ Solid Waste } \\
\hline & & & & & & & \multicolumn{3}{|c|}{ Form of Disposal } & \multirow[b]{2}{*}{$\begin{array}{l}\text { Total } \\
\text { Volume } \\
\left(\mathrm{m}^{3}\right)\end{array}$} & \multirow[b]{2}{*}{$\begin{array}{l}\text { Total } \\
\text { Activity } \\
\text { (TBq) }\end{array}$} \\
\hline & $\begin{array}{l}\text { North } \\
\text { Latitude } \\
\end{array}$ & $\begin{array}{l}\text { East } \\
\text { Latitude } \\
\end{array}$ & & & $\begin{array}{l}\text { Total } \\
\text { Volume } \\
\left(\mathrm{m}^{3}\right) \\
\end{array}$ & $\begin{array}{l}\text { Total } \\
\text { Activity } \\
\text { (TBq) }\end{array}$ & Containers & Ships & $\begin{array}{l}\text { Unenclosed } \\
\text { Objects }\end{array}$ & & \\
\hline \multirow[t]{3}{*}{ Area 1} & $42^{\circ} 0^{\prime}$ & $133^{\circ} 10^{\prime}$ & \multirow[t]{3}{*}{$3.25-3.7$} & \multirow{3}{*}{$\begin{array}{l}\text { Not } \\
\text { specified }\end{array}$} & \multirow[t]{3}{*}{16,250} & \multirow[t]{3}{*}{0.056} & \multirow[t]{3}{*}{ - } & \multirow[t]{3}{*}{-} & \multirow[t]{3}{*}{-} & \multirow[t]{3}{*}{-} & \multirow[t]{3}{*}{-} \\
\hline & $\begin{array}{l}42^{\circ} 0^{\prime} \\
41^{\circ} 0^{\prime}\end{array}$ & $\begin{array}{l}134^{\circ} 30^{\prime} \\
133^{\circ} 10^{\prime}\end{array}$ & & & & & & & & & \\
\hline & $41^{\circ} 0^{\prime}$ & $134^{\circ} 30^{\prime}$ & & & & & & & & & \\
\hline \multirow[t]{4}{*}{ Area 2} & $41^{\circ} 10^{\prime}$ & $131^{\circ} 10^{\prime}$ & \multirow[t]{4}{*}{$2.9-3.3$} & \multirow{4}{*}{$\begin{array}{l}\text { Not } \\
\text { specified }\end{array}$} & \multirow[t]{4}{*}{3,156} & \multirow[t]{4}{*}{0.033} & \multirow[t]{4}{*}{-} & \multirow[t]{4}{*}{-} & \multirow[t]{4}{*}{-} & \multirow[t]{4}{*}{-} & \multirow[t]{4}{*}{-} \\
\hline & $41^{\circ} 10^{\prime}$ & $134^{\circ} 30^{\prime}$ & & & & & & & & & \\
\hline & $39^{\circ} 30^{\prime}$ & $131^{\circ} 10^{\prime}$ & & & & & & & & & \\
\hline & $39^{\circ} 30^{\prime}$ & $134^{\circ} 30^{\prime}$ & & & & & & & & & \\
\hline \multirow[t]{4}{*}{ Area 5} & $42^{\circ} 26^{\prime}$ & $131^{\circ} 37^{\prime}$ & $1.1-1.5$ & $1966-1974$ & 3,830 & 3.4 & - & - & - & - & - \\
\hline & $42^{\circ} 26^{\prime}$ & $132^{\circ} 20^{\prime}$ & & 1986 & 259 & 0.006 & - & - & - & - & - \\
\hline & $42^{\circ} 17^{\prime}$ & $131^{\circ} 37^{\prime}$ & & 1988 & 1,808 & 0.62 & - & - & - & - & - \\
\hline & $42^{\circ} 17^{\prime}$ & $132^{\circ} 20^{\prime}$ & & $1990-1992$ & 1,939 & 0.27 & - & - & - & - & - \\
\hline Area 6 & $41^{\circ} 55^{\prime}$ & $131^{\circ} 47^{\prime}$ & $1.9-3.3$ & $1968-1971$ & - & - & 2,455 & 一 & - & 2,455 & 13 \\
\hline & $41^{\circ} 55^{\prime}$ & $132^{\circ} 13^{\prime}$ & & 1973 & 一 & - & 241 & 2 & - & 861 & 6.8 \\
\hline & $41^{\circ} 45^{\prime}$ & $131^{\circ} 47^{\prime}$ & & $1986-1987$ & 5,072 & 18 & - & - & - & - & - \\
\hline & $41^{\circ} 45^{\prime}$ & $132^{\circ} 13^{\prime}$ & & $1986-1988$ & - & - & 219 & 3 & 2 & 1,093 & 12 \\
\hline Area 9 & $41^{\circ} 46^{\prime}$ & $133^{\circ} 22^{\prime}$ & $3.25-3.7$ & $1974-1978$ & 14,827 & 2.2 & 990 & 10 & - & 2,809 & 34 \\
\hline & $41^{\circ} 46^{\prime}$ & $134^{\circ} 42^{\prime}$ & & $1984-1992$ & 18,143 & 400 & 698 & 10 & 26 & 7,017 & 79 \\
\hline & $\begin{array}{l}41^{\circ} 36^{\prime} \\
41^{\circ} 36^{\prime}\end{array}$ & $\begin{array}{l}133^{\circ} 22^{\prime} \\
134^{\circ} 42^{\prime}\end{array}$ & & & & & & & & & \\
\hline Area 10 & $41^{\circ} 10^{\prime}$ & $131^{\circ} 15^{\prime}$ & $2.9-3.3$ & $1978-1983$ & - & - & 729 & 10 & 12 & 4,518 & 23 \\
\hline & $41^{\circ} 10^{\prime}$ & $131^{\circ} 35^{\prime}$ & & $1979-1984$ & 17,608 & 20 & - & - & - & 一 & - \\
\hline & $40^{\circ} 10^{\prime}$ & $131^{\circ} 15^{\prime}$ & & & & & & & & & \\
\hline & $40^{\circ} 10^{\prime}$ & $131^{\circ} 35^{\prime}$ & & & & & & & & & \\
\hline Total & & & & & 82,892 & 440 & 5,332 & 35 & 40 & 18,753 & 170 \\
\hline
\end{tabular}




\section{Disposal}

The Sea of Okhotsk disposal site (designated as Area 3) depth was unspecified and was only used for the disposal of LRW. The White Book indicated that a total volume of $1,513 \mathrm{~m}^{3}$ of LRW was disposed, containing $0.004 \mathrm{TBq}$ of unspecified radionuclides. Table 2-4 presents a detailed summary of the pertinent disposal information contained in the White Book for the LRW dumped in the Sea of Okhotsk, including the disposal site coordinates.

Table 2-4. Pertinent disposal information for the liquid radioactive waste dumped in the Sea of Okhotsk, as presented in the White Book (Yablokov et al., 1993).

\begin{tabular}{ccccccc} 
& \multicolumn{2}{c}{ Site Coordinates } & & \multicolumn{2}{c}{ Liquid Waste } \\
\cline { 2 - 3 } $\begin{array}{c}\text { Site } \\
\text { Designation }\end{array}$ & $\begin{array}{c}\text { North } \\
\text { Latitude }\end{array}$ & $\begin{array}{c}\text { East } \\
\text { Latitude }\end{array}$ & $\begin{array}{c}\text { Disposal } \\
\text { Depth }(\mathrm{km})\end{array}$ & Time Period & $\begin{array}{c}\text { Total } \\
\text { Volume } \\
\left(\mathrm{m}^{3}\right)\end{array}$ & $\begin{array}{c}\text { Total } \\
\text { Activity } \\
(\mathrm{TBq})\end{array}$ \\
\hline Area 3 & $53^{\circ} 0^{\prime}$ & $146^{\circ} 40^{\prime}$ & Not available & Not available & 1,513 & 0.004 \\
& $53^{\circ} 0^{\prime}$ & $148^{\circ} 10^{\prime}$ & & & & \\
& $51^{\circ} 20^{\prime}$ & $146^{\circ} 40^{\prime}$ & & & & \\
$51^{\circ} 20^{\prime}$ & $148^{\circ} 10^{\prime}$ & & & & \\
\end{tabular}

\section{Pacific Ocean, East Coast of Kamchatka}

The Pacific Ocean, east coast of Kamchatka, disposal sites (designated as Areas 4, 7, and 8) varied in depth from 1.4 to $2.57 \mathrm{~km}$ and were used for the disposal of both LRW and SRW. According to the White Book, 34,289 $\mathrm{m}^{3}$ of LRW were disposed of between 1966 and 1992, and contained a total activity at the time of disposal of about $13 \mathrm{TBq}$ of unspecified origin. SRW were disposed between 1969 and 1992, with a total activity at the time of disposal of about $110 \mathrm{TBq}$ of unspecified origin. The wastes included 1,502 containers, 2 ships, and 64 unenclosed objects.

Figure 2-2 shows the disposal sites for LRW in the Sea of Japan; Sea of Okhotsk; and the Pacific Ocean, east coast of Kamchatka. Figure 2-3 shows the disposal sites for SRW in the Sea of Japan, Sea of Okhotsk, and the Pacific Ocean, east coast of Kamchatka. Table 2-5 presents a detailed summary of the pertinent disposal information contained in the White Book for the LRW and SRW dumped in the Pacific Ocean, east coast of Kamchatka, including the disposal site coordinates. 


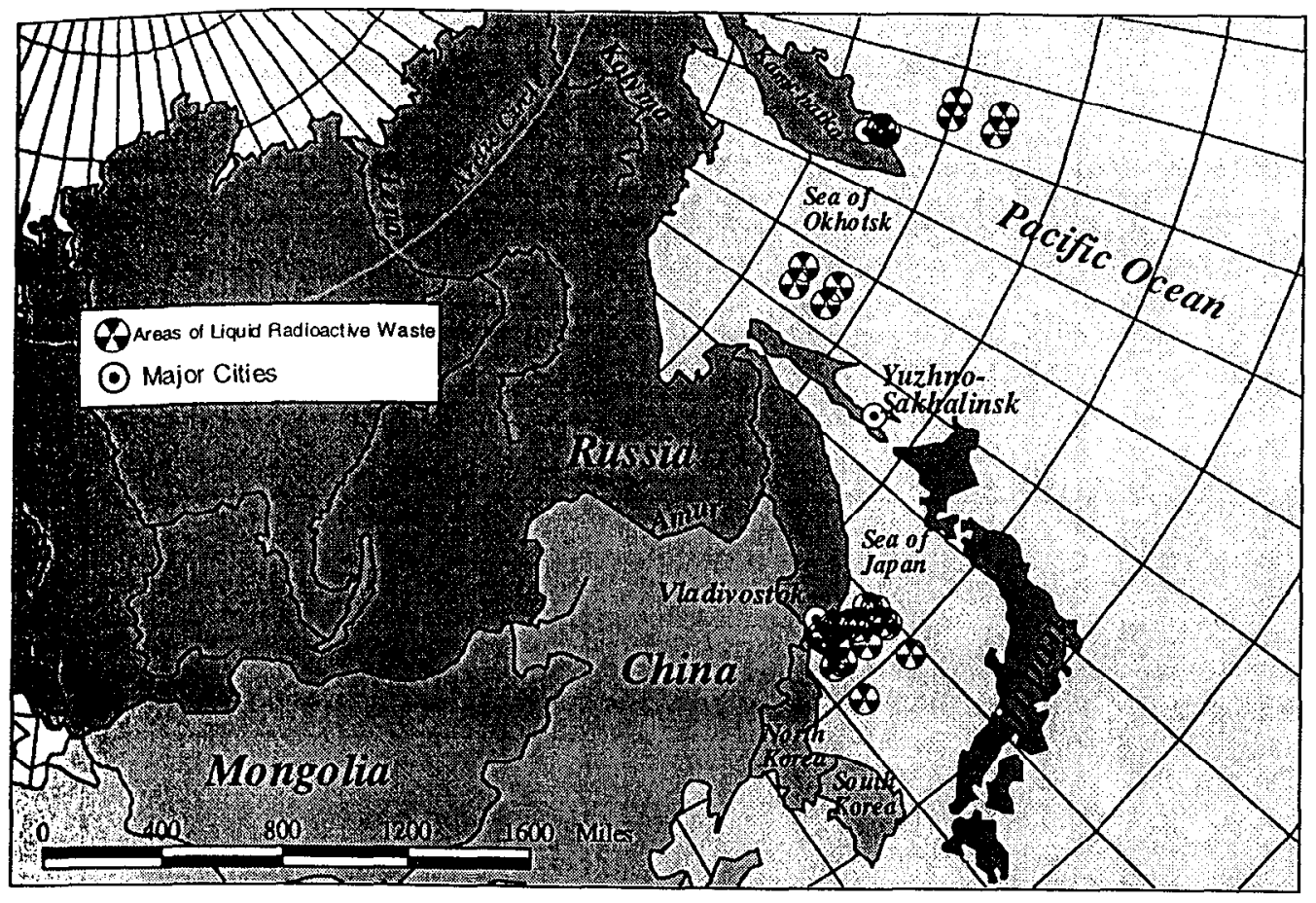

Figure 2-2.

Liquid

radioactive

waste disposal

sites in the Sea

of Japan; Sea of

Okhotsk; and

the Pacific

Ocean, east

coast of

Kamchatka.

Figure 2-3. Solid radioactive waste disposal sites in the Sea of Japan; Sea of Okhotsk; and the Pacific Ocean, east coast of Kamchatka.

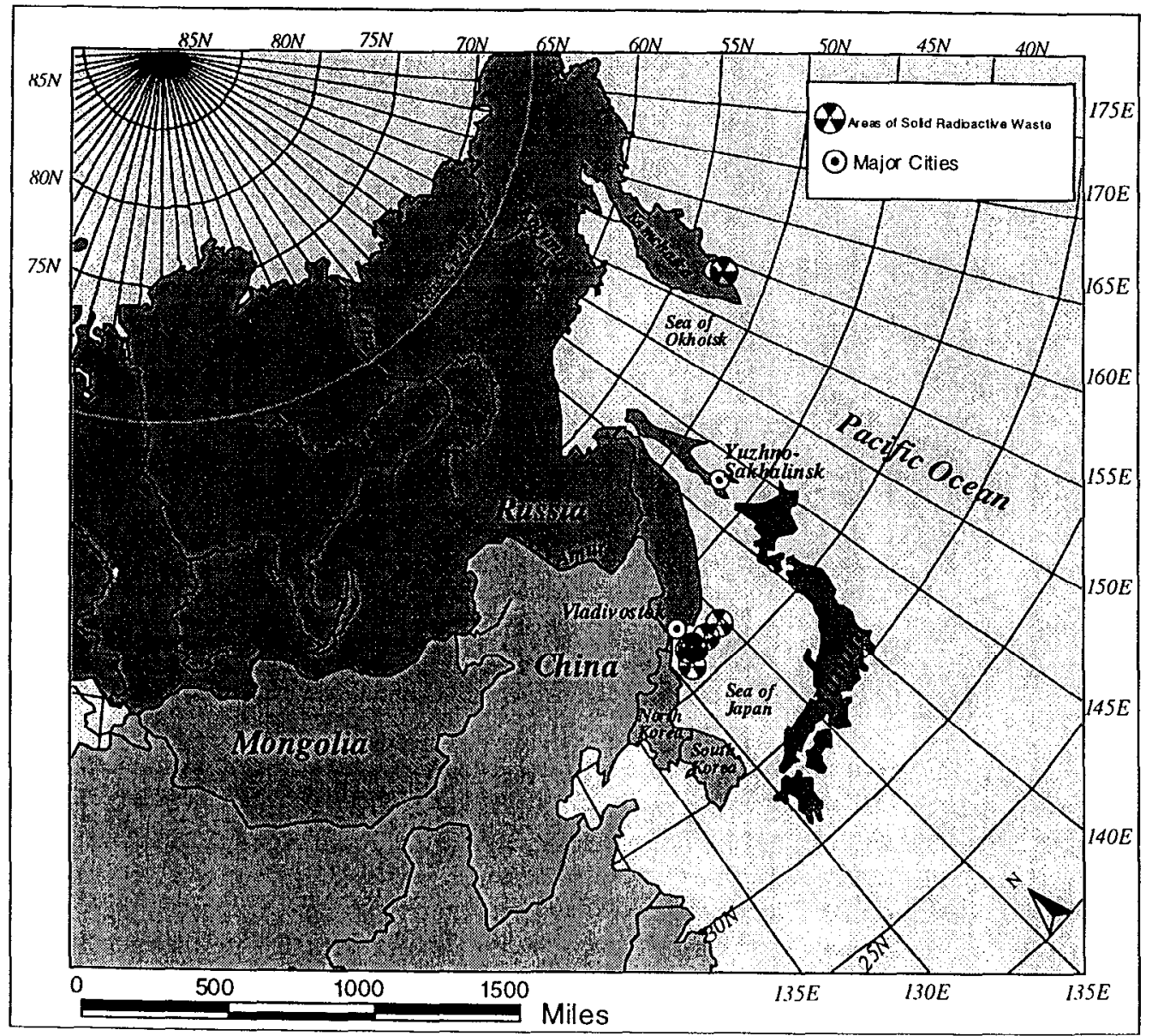


Table 2-5. Pertinent disposal information for the liquid and solid radioactive waste dumped in the Pacific Ocean, east coast of Kamchatka, as presented in the White Book (Yablokov et al., 1993).

Solid Waste

\begin{tabular}{|c|c|c|c|c|c|c|c|c|c|c|c|}
\hline \multirow[b]{2}{*}{$\begin{array}{l}\text { Site } \\
\text { Designation }\end{array}$} & \multicolumn{2}{|c|}{ Site Coordinates } & \multirow[b]{2}{*}{$\begin{array}{l}\text { Disposal } \\
\text { Depth }(\mathrm{km})\end{array}$} & \multirow[b]{2}{*}{ Time Period } & \multicolumn{2}{|c|}{ Liquid Waste } & \multicolumn{3}{|c|}{ Form of Disposal } & \multirow[b]{2}{*}{$\begin{array}{l}\text { Total } \\
\text { Volume } \\
\left(\mathrm{m}^{3}\right)\end{array}$} & \multirow[b]{2}{*}{$\begin{array}{l}\text { Total } \\
\text { Activity } \\
\text { (TBq) }\end{array}$} \\
\hline & $\begin{array}{l}\text { North } \\
\text { Latitude }\end{array}$ & $\begin{array}{l}\text { East } \\
\text { Latitude }\end{array}$ & & & $\begin{array}{l}\text { Total } \\
\text { Volume } \\
\left(\mathrm{m}^{3}\right)\end{array}$ & $\begin{array}{l}\text { Total } \\
\text { Activity } \\
\text { (TBq) }\end{array}$ & Containers & Ships & $\begin{array}{l}\text { Unenclosed } \\
\text { Objects }\end{array}$ & & \\
\hline \multirow[t]{4}{*}{ Area 4} & $50^{\circ} 0^{\prime}$ & $161^{\circ} 35^{\prime}$ & \multirow{4}{*}{$\begin{array}{l}\text { Not } \\
\text { specified }\end{array}$} & \multirow{4}{*}{$\begin{array}{l}\text { Not } \\
\text { specified }\end{array}$} & \multirow[t]{4}{*}{4,803} & \multirow[t]{4}{*}{0.007} & \multirow[t]{4}{*}{ - } & \multirow[t]{4}{*}{-} & \multirow[t]{4}{*}{-} & \multirow[t]{4}{*}{-} & \multirow[t]{4}{*}{-} \\
\hline & $50^{\circ} 0^{\prime}$ & $162^{\circ} 45^{\prime}$ & & & & & & & & & \\
\hline & $48^{\circ} 0^{\prime}$ & $161^{\circ} 35^{\prime}$ & & & & & & & & & \\
\hline & $48^{\circ} 0^{\prime}$ & $162^{\circ} 40^{\prime}$ & & & & & & & & & \\
\hline \multirow[t]{4}{*}{ Area 7} & $52^{\circ} 40^{\prime}$ & $159^{\circ} 2^{\prime}$ & \multirow[t]{4}{*}{$1.4-1.5$} & $1966-1975$ & 10,456 & 0.27 & - & - & - & - & - \\
\hline & $52^{\circ} 40^{\prime}$ & $159^{\circ} 12^{\prime}$ & & $1977-1978$ & 3,851 & 0.23 & - & - & - & - & - \\
\hline & $52^{\circ} 28^{\prime}$ & $159^{\circ} 2^{\prime}$ & & $1980-1992$ & 19,982 & 12 & - & - & - & - & - \\
\hline & $52^{\circ} 28^{\prime}$ & $159^{\circ} 12^{\prime}$ & & & & & & & & & \\
\hline \multirow[t]{4}{*}{ Area 8} & $52^{\circ} 34^{\prime}$ & $159^{\circ} 6^{\prime}$ & \multirow[t]{4}{*}{$2.0-2.57$} & $1969-1978$ & - & - & 460 & 1 & - & 758 & 19 \\
\hline & $52^{\circ} 34^{\prime}$ & $159^{\circ} 11^{\prime}$ & & $1980-1983$ & - & - & 297 & - & - & 297 & 13 \\
\hline & $52^{\circ} 28^{\prime}$ & $159^{\circ} 2^{\prime}$ & & $1986-1992$ & - & - & 745 & 1 & 64 & 1,498 & 79 \\
\hline & $52^{\circ} 28^{\prime}$ & $159^{\circ} 11^{\prime}$ & & & & & & & & & \\
\hline Total & & & & & 34,289 & 13 & 1,502 & 2 & 64 & 2,553 & 110 \\
\hline
\end{tabular}




\subsection{Sources IN THE West Siberian Basin}

The primary sources of nuclear wastes in the West Siberian Basin, as depicted in Figure 2-4, are the nuclear-weapons plants at Mayak, Tomsk 7, and Krasnoyarsk 26 and the nuclear-weapons test site at Semipalatinsk. Each of the three weapons-production sites have nuclear reactors and related facilities for producing and processing ${ }^{239} \mathrm{Pu}$ for nuclear weapons. Nuclear materials from these sites already have contaminated rivers that flow into the Kara Sea, and existing LRWs stored at the various locations constitute a future threat to the rivers (see Bradley and Jenquin, 1995).

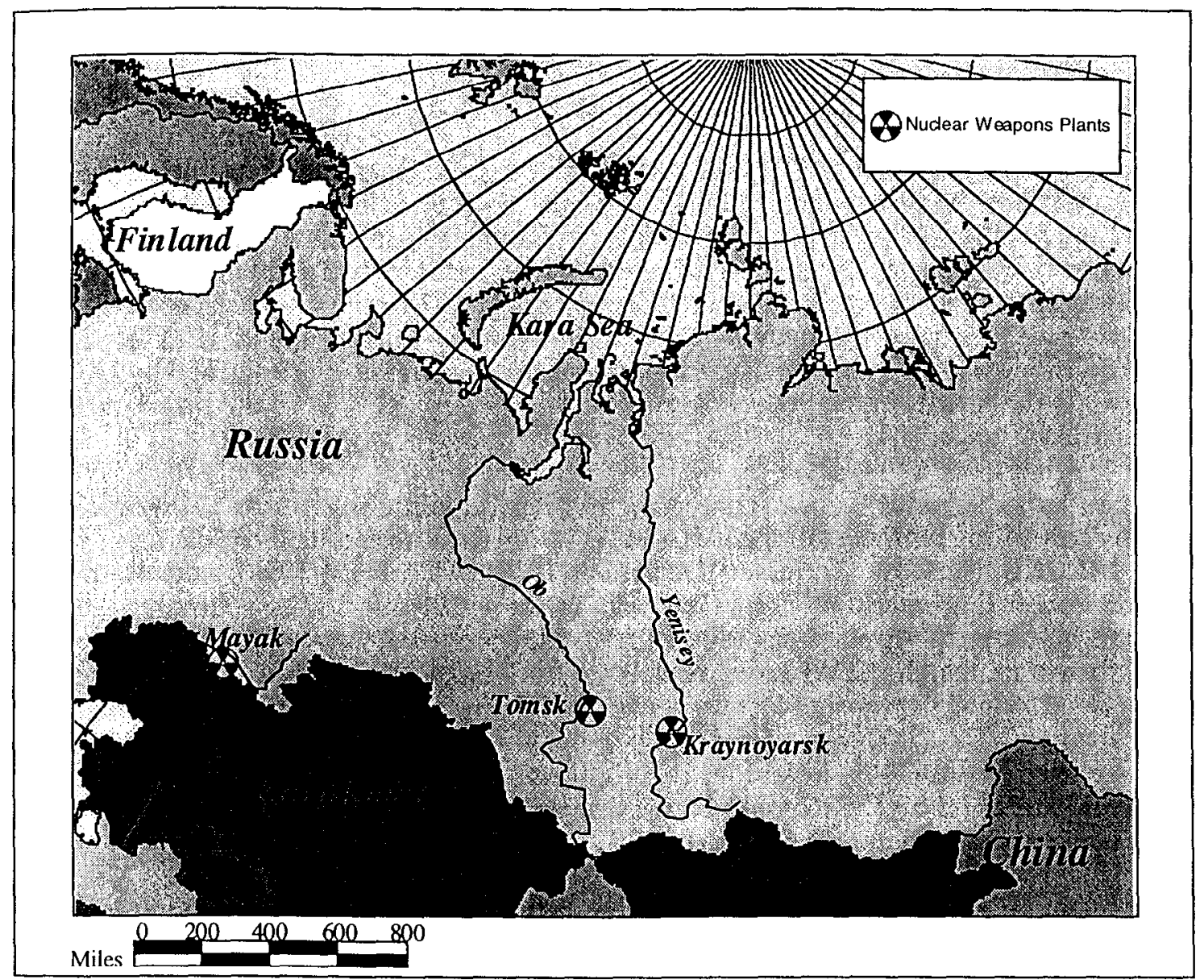

Figure 2-4. Locations of nuclear-weapons plants in the West Siberian Basin.

The LRWs produced from these sites have been managed in various ways. During the years 1949 to 1951 at the Mayak site, for example, LRWs were discharged directly to the Techa River (a tributary of the $\mathrm{Ob}$ ), contaminating marshes, river water, and related sediments for hundreds of kilometers downstream (Trapeznikov et al., 1993). Later, the LRWs were diverted to Lake Karachai (denoted Reservoir 9) and a series of other surface reservoirs. High-level radioactive wastes are now stored in single-wall tanks. At Tomsk 7 and Krasnoyarsk 26, LRWs also are stored in surface reservoirs; however, the principal method of LRW disposal at those two sites has been the injection of wastes into subsurface geologic media via special wells. Discharges of once-through cool- 
ing waters from the nuclear reactors at Tomsk 7 (to the Tom River, a tributary of the Ob) and Krasnoyarsk 26 (to the Yenisey River) also have resulted in the contamination of river water and sediments with fission products, actinides, and activation products. The dominant radionuclides from those releases, though, are short-lived activation products such as ${ }^{51} \mathrm{Cr},{ }^{32} \mathrm{P}$, and ${ }^{59} \mathrm{Fe}$ (Vakulovsky et al., 1995). At the nuclear test site at Semipalatinsk, the principal source of potential contamination to the Irtysh River (a tributary of the $\mathrm{Ob}$ ) is runoff from lands contaminated with radionuclides from nuclear testing.

\subsection{RADIONUCLIDE INVENTORIES}

\subsubsection{Kara Sea}

The White Book reported estimates of total radioactivity at the time of disposal; these were 85,000 $\mathrm{TBq}$ of fission products in the SNF; $3,700 \mathrm{TBq}$ of activation products in the reactor components; $890 \mathrm{TBq}$ of unspecified origin in the low-level LRW, over $50 \%$ of which was discharged in the Barents Sea; and $590 \mathrm{TBq}$ of unspecified origin in the low- and intermediate-level SRW, over 95\% of which was discarded in the Kara Sea (Yablokov et al., 1993). With rare exception, the report identified no radionuclides and provided no estimate for the current levels of radioactivity. The methods and models used to quantify the radionuclide inventories are described by IAEA (1996), which presents the results of the Source Term Working Group (STWG) of the International Arctic Seas Assessment Project (IASAP).

Two independent estimates were prepared for the radionuclide inventories. One estimate was prepared by consulting members of the I $\triangle E A$ STWG from the Russian Research Center "Kurchatov Institute" (RRCKI), Moscow (Sivintsev, December 1993 and August 1994), and the Institute of Physics and Power Engineering (IPPE), Obninsk (Yefimov, 1994). Another estimate was prepared by the State Institute of Applied Ecology (SIAE), Moscow (Rubtsov and Ruzhansky, 1995). In preparing the estimates, the STWG core models for the PWRs and LMRs were represented by the icebreaker OK-150 and submarine factory number 601 core models, respectively, while the SIAE estimates used a VVER-1,000 core model to represent both the PWR and LMR cores. Values of the fuel burn-up used in the STWG inventory calculations came from RRCKI and IPPE records; those for SIAE were supplied by the Russian Navy. Computer programs used in both inventory estimates are well established and benchmarked.

Results from the STWG estimate, when compared with those from SIAE, showed the following:

(1) Fission products are in good agreement for the icebreaker and no worse than a factor of 0.5 for the nuclear submarines; and

(2) Actinides agree within a factor of 0.5 for the icebreaker and are no worse than a factor of 0.1 for the nuclear submarines.

Upon consideration of the above, the STWG concluded that even though SIAE results tend to be higher, and therefore more conservative, they do not represent the best estimate for the IASAP effort. First and foremost, the core models used in the STWG estimate for the icebreaker and submarine factory number 601 represent the actual configurations; the SIAE models do not. Second, even though there are differences between the core configurations of the nuclear submarine 
and icebreaker PWRs, the OK-150 model is more representative of the true core configurations than that of the VVER-1,000. This is further substantiated by the fact that comparisons of the STWG actinide results to those in other Russian reports (Sivintsev, September 1995) indicated differences of no more than $\pm 20 \%$. Table 2-6 shows estimated 1994 radionuclide inventories of fission products, activation products, and actinides in the marine reactors dumped in the Kara Sea. Table 2-7 shows estimated 1994 activity of long-lived radionuclides at each disposal site from the marine reactors dumped in the Kara Sea. With respect to an upper estimate of the limit on the total radioactivity dumped in the Kara Sea, the STWG estimate of 37,000 TBq is approximately a factor 2.4 less than the $88,000 \mathrm{TBq}$ estimate of the White Book, and approximately a factor of 6 less than the $210,000 \mathrm{TBq}$ estimate obtained from an independent calculation of the reactor fuel burn-up based on the operating characteristics and power requirements of the vessels (Mount et al., 1994).

One other potential source of radioactivity in the SNF associated with the dumped reactors is a nuclear criticality event. Criticality occurs when, on average, more than one fission event is produced per fission neutron generated. The key parameters influencing a criticality event are the geometry of the fissionable material and its composition. The STWG examined alternative mechanisms that could lead to criticality in SNF (e.g., corrosion of control rod material, leading to enhanced neutron fluency in residual fuel) and concluded that in some special circumstances the nuclear fuel could achieve a critical state. Nevertheless, the amount of additional fission products created in such an event would be insignificant compared to the estimated inventories presented in Table 2-7. 
Table 2-6. Estimated 1994 radionuclide inventories of fission products, activation products, and actinides in the marine reactors dumped in the Kara Sea (from IAEA, 1997; based on October 1995).

\begin{tabular}{|c|c|c|c|c|c|c|c|c|}
\hline \multirow{3}{*}{$\begin{array}{l}\text { Factory } \\
\text { Number }\end{array}$} & \multicolumn{8}{|c|}{ Activity in 1994} \\
\hline & \multicolumn{2}{|c|}{ Fission Products } & \multicolumn{2}{|c|}{ Activation Products } & \multicolumn{2}{|c|}{ Actinides } & \multicolumn{2}{|c|}{ Total } \\
\hline & $\mathrm{Bq}$ & $\begin{array}{c}\text { Percent } \\
(\%)\end{array}$ & $\mathrm{Bq}$ & $\begin{array}{l}\text { Percent } \\
(\%)\end{array}$ & $\mathrm{Bq}$ & $\begin{array}{c}\text { Percent } \\
(\%)\end{array}$ & $\mathrm{Bq}$ & $\begin{array}{c}\text { Percent } \\
(\%)\end{array}$ \\
\hline 901 & $7.2 \times 10^{14}$ & 15 & $6.0 \times 10^{12}$ & 0.13 & $3.4 \times 10^{12}$ & 0.073 & $7.3 \times 10^{14}$ & 15 \\
\hline 285 & $6.3 \times 10^{14}$ & 14 & $1.3 \times 10^{13}$ & 0.27 & $8.1 \times 10^{12}$ & 0.17 & $6.5 \times 10^{14}$ & 14 \\
\hline 254 & - & - & $9.5 \times 10^{12}$ & 0.20 & - & - & $9.5 \times 10^{12}$ & 0.20 \\
\hline 260 & - & - & $5.1 \times 10^{12}$ & 0.11 & - & - & $5.1 \times 10^{12}$ & 0.11 \\
\hline OK- $150^{1}$ & $1.8 \times 10^{15}$ & 39 & $2.3 \times 10^{14}$ & 5.0 & $8.3 \times 10^{13}$ & 8 & $2.2 \times 10^{15}$ & 46 \\
\hline 421 & $2.9 \times 10^{1.4}$ & 6.1 & $2.9 \times 10^{12}$ & 0.062 & $2.8 \times 10^{12}$ & 0.061 & $2.9 \times 10^{14}$ & 6.2 \\
\hline 601 & $5.3 \times 10^{14}$ & 11 & $3.0 \times 10^{14}$ & 6.5 & $3.6 \times 10^{11}$ & 0.008 & $8.4 \times 10^{14}$ & 18 \\
\hline 538 & - & - & $4.5 \times 10^{12}$ & 0.096 & - & - & $4.5 \times 10^{12}$ & 0.096 \\
\hline Total & $4.0 \times 10^{15}$ & 86 & $5.7 \times 10^{14}$ & 12 & $9.7 \times 10^{13}$ & 2.1 & $4.7 \times 10^{15}$ & 10000 \\
\hline
\end{tabular}

${ }^{1}$ The fission product, actinide, and $27 \%$ of activation product activities were discarded in a reinforced concrete and stainless steel container. 
Table 2-7. Estimated 1994 activity of long-lived radionuclides at each disposal site from the marine reactors dumped in the Kara Sea (from IAEA, 1997; based on October 1995).

\begin{tabular}{|c|c|c|c|c|c|c|}
\hline \multirow[t]{2}{*}{ Radionuclide } & $\begin{array}{c}\text { Abrosimov } \\
\text { Fjord }\end{array}$ & $\begin{array}{l}\text { Tsivolka } \\
\text { Fjord }\end{array}$ & $\begin{array}{c}\text { Novaya } \\
\text { Zemlya } \\
\text { Depression }\end{array}$ & $\begin{array}{l}\text { Stepovoy } \\
\text { Fjord }\end{array}$ & $\begin{array}{c}\text { Techeniye } \\
\text { Fjord }\end{array}$ & $\begin{array}{c}\text { Kara Sea } \\
\text { Total } \\
\end{array}$ \\
\hline & & \multicolumn{5}{|c|}{ Activity in $1994(\mathrm{~Bq})$} \\
\hline \multicolumn{7}{|l|}{ Fission products } \\
\hline${ }^{3} \mathrm{H}$ & $3.1 \times 10^{12}$ & $8.3 \times 10^{11}$ & $1.6 \times 10^{11}$ & $4.8 \times 10^{\mathrm{t} 3}$ & - & $5.2 \times 10^{13}$ \\
\hline${ }^{85} \mathrm{Kr}$ & $1.1 \times 10^{13}$ & $1.7 \times 10^{13}$ & $3.3 \times 10^{12}$ & $7.2 \times 10^{12}$ & - & $3.9 \times 10^{13}$ \\
\hline "'s $\mathrm{Sr}$ & $3.2 \times 10^{14}$ & $4.4 \times 10^{14}$ & $7.4 \times 10^{1.3}$ & $1.2 \times 10^{14}$ & - & $9.5 \times 10^{14}$ \\
\hline${ }^{40} \mathrm{Y}$ & $3.2 \times 10^{14}$ & $4.4 \times 10^{14}$ & $7.4 \times 10^{13}$ & $1.2 \times 10^{14}$ & - & $9.5 \times 10^{14}$ \\
\hline${ }^{49 \prime} \mathrm{TC}$ & $9.6 \times 10^{111}$ & $1.3 \times 10^{11}$ & $1.9 \times 10^{10}$ & $3.0 \times 10^{10}$ & - & $2.8 \times 10^{11}$ \\
\hline${ }^{125} \mathrm{Sb}$ & $2.8 \times 10^{10}$ & $5.8 \times 10^{30}$ & $2.2 \times 10^{10}$ & $5.9 \times 10^{10}$ & - & $1.7 \times 10^{11}$ \\
\hline${ }^{124} \mathrm{I}$ & $9.4 \times 10^{7}$ & $2.1 \times 10^{8}$ & $1.9 \times 10^{7}$ & $6.5 \times 10^{7}$ & - & $3.9 \times 10^{8}$ \\
\hline${ }^{137} \mathrm{Cs}$ & $3.5 \times 10^{14}$ & $4.8 \times 10^{14}$ & $6.8 \times 10^{13}$ & $1.3 \times 10^{14}$ & - & $1.0 \times 10^{15}$ \\
\hline${ }^{137}$ Bam & $3.4 \times 10^{14}$ & $4.6 \times 10^{14}$ & $6.5 \times 10^{13}$ & $1.2 \times 10^{14}$ & - & $9.9 \times 10^{14}$ \\
\hline${ }^{147} \mathrm{Pm}$ & $5.7 \times 10^{11}$ & $1.4 \times 10^{12}$ & $4.7 \times 10^{11}$ & $9.2 \times 10^{y}$ & - & $2.4 \times 10^{12}$ \\
\hline${ }^{151} \mathrm{Sm}$ & $7.8 \times 10^{12}$ & $1.1 \times 10^{13}$ & $1.7 \times 10^{12}$ & $3.7 \times 10^{12}$ & - & $2.4 \times 10^{13}$ \\
\hline${ }^{155} \mathrm{Eu}$ & - & - & - & $9.6 \times 10^{10}$ & - & $9.6 \times 10^{10}$ \\
\hline Subtotal & $1.4 \times 10^{15}$ & $1.8 \times 10^{15}$ & $2.9 \times 10^{14}$ & $5.3 \times 10^{14}$ & - & $4.0 \times 10^{15}$ \\
\hline \multicolumn{7}{|l|}{ Activation products } \\
\hline${ }^{14} \mathrm{C}$ & $1.5 \times 10^{11}$ & $1.6 \times 10^{6}$ & $1.2 \times 10^{10}$ & - & $2.4 \times 10^{4}$ & $1.6 \times 10^{11}$ \\
\hline${ }^{610} \mathrm{Co}$ & $6.2 \times 10^{12}$ & $4.2 \times 10^{13}$ & $9.8 \times 10^{11}$ & $9.3 \times 10^{13}$ & $1.0 \times 10^{12}$ & $1.4 \times 10^{14}$ \\
\hline${ }^{54} \mathrm{Ni}$ & $4.9 \times 10^{12}$ & $1.8 \times 10^{12}$ & $1.0 \times 10^{11}$ & $1.6 \times 10^{12}$ & $1.9 \times 10^{11}$ & $8.6 \times 10^{12}$ \\
\hline${ }^{63} \mathrm{Ni}$ & $2.2 \times 10^{13}$ & $1.8 \times 10^{14}$ & $1.8 \times 10^{12}$ & $1.4 \times 10^{14}$ & $3.3 \times 10^{12}$ & $3.5 \times 10^{14}$ \\
\hline${ }^{152} \mathrm{Eu}$ & - & - & - & $6.0 \times 10^{13}$ & - & $6.0 \times 10^{13}$ \\
\hline${ }^{154} \mathrm{Eu}$ & 一 & - & - & $1.1 \times 10^{13}$ & - & $1.1 \times 10^{13}$ \\
\hline${ }^{2115} \mathrm{~Pb}$ & - & - & - & $1.9 \times 10^{8}$ & - & $1.9 \times 10^{8}$ \\
\hline${ }^{2117} \mathrm{Bi}$ & - & - & - & $1.7 \times 10^{10}$ & - & $1.7 \times 10^{10}$ \\
\hline${ }^{2118} \mathrm{Bi}$ & - & - & - & $6.2 \times 10^{9}$ & - & $6.2 \times 10^{9}$ \\
\hline${ }^{211} \mathrm{Bim}$ & - & 一 & - & $3.4 \times 10^{9}$ & - & $3.4 \times 10^{9}$ \\
\hline Subtotal & $3.4 \times 10^{13}$ & $2.3 \times 10^{14}$ & $2.9 \times 10^{12}$ & $3.0 \times 10^{14}$ & $4.5 \times 10^{12}$ & $5.7 \times 10^{14}$ \\
\hline \multicolumn{7}{|l|}{ Actinides } \\
\hline${ }^{238} \mathrm{Pu}$ & $5.2 \times 10^{11}$ & $1.0 \times 10^{12}$ & $8.7 \times 10^{10}$ & $8.6 \times 10^{9}$ & - & $1.6 \times 10^{12}$ \\
\hline${ }^{239} \mathrm{Pu}$ & $7.5 \times 10^{11}$ & $5.0 \times 10^{12}$ & $1.1 \times 10^{11}$ & $3.4 \times 10^{11}$ & - & $6.2 \times 10^{12}$ \\
\hline${ }^{2411} \mathrm{Pu}$ & $3.4 \times 10^{11}$ & $2.3 \times 10^{12}$ & $3.9 \times 10^{10}$ & $6.6 \times 10^{y}$ & - & $2.7 \times 10^{12}$ \\
\hline${ }^{241} \mathrm{Pu}$ & $8.8 \times 10^{12}$ & $6.7 \times 10^{13}$ & $2.4 \times 10^{12}$ & $2.8 \times 10^{9}$ & - & $7.8 \times 10^{13}$ \\
\hline${ }^{241} \mathrm{Am}$ & $1.1 \times 10^{12}$ & $7.1 \times 10^{12}$ & $1.6 \times 10^{11}$ & $1.1 \times 10^{y}$ & - & $8.3 \times 10^{12}$ \\
\hline Subtotal & $1.2 \times 10^{13}$ & $8.3 \times 10^{13}$ & $2.8 \times 10^{12}$ & $3.6 \times 10^{11}$ & - & $9.7 \times 10^{13}$ \\
\hline Total & $1.4 \times 10^{15}$ & $2.2 \times 10^{15}$ & $2.9 \times 10^{14}$ & $8.4 \times 10^{14}$ & $4.5 \times 10^{12}$ & $4.7 \times 10^{15}$ \\
\hline
\end{tabular}


N Table 2-8. Estimated 1994 activity of long-lived activation products in the reactor-related unenclosed solid radioactive waste dumped i in the Sea of Japan and the Pacific Ocean, east coast of Kamchatka.

\begin{tabular}{|c|c|c|c|c|c|c|c|c|}
\hline \multirow[b]{3}{*}{$\begin{array}{l}\text { Site } \\
\text { Designation }\end{array}$} & \multirow[b]{3}{*}{$\begin{array}{c}\text { Year of } \\
\text { Disposal }{ }^{1}\end{array}$} & \multirow[b]{3}{*}{ Dumped Unit ${ }^{1}$} & \multirow[b]{3}{*}{$\begin{array}{l}\text { Disposal } \\
\text { Coordinates }^{1}\end{array}$} & \multirow[b]{3}{*}{$\begin{array}{l}\text { Disposal } \\
\text { Depth }(\mathrm{km})^{2}\end{array}$} & \multicolumn{4}{|c|}{ Radionuclide } \\
\hline & & & & & ${ }^{14} \mathrm{C}$ & ${ }^{60} \mathrm{Co}$ & ${ }^{59} \mathrm{Ni}$ & ${ }^{63} \mathrm{Ni}$ \\
\hline & & & & & \multicolumn{4}{|c|}{ Activity in $1994(\mathrm{GBq})^{3}$} \\
\hline \multirow[t]{4}{*}{ Area 8} & 1986 & $\begin{array}{l}\text { Primary loop circulating } \\
\text { pump (50 pieces) }\end{array}$ & $\begin{array}{l}52^{\circ} 31^{\prime} \mathrm{N} \\
159^{\circ} 8^{\prime} \mathrm{E}\end{array}$ & $2.0-2.57$ & 0.00021 & 500 & 0.018 & 3.3 \\
\hline & 1988 & Steam generator (10 pieces) & $\begin{array}{l}52^{\circ} 30^{\prime} \mathrm{N} \\
159^{\circ} 9^{\prime} \mathrm{E}\end{array}$ & $2.0-2.57$ & 0.00031 & 990 & 0.028 & 5.0 \\
\hline & 1989 & Submarine core plate & $\begin{array}{l}52^{\circ} 30^{\prime} \mathrm{N} \\
159^{\circ} 9^{\prime} \mathrm{E}\end{array}$ & $2.0-2.57$ & 0.90 & 1,000 & 29 & 330 \\
\hline & & $\begin{array}{l}\text { Primary loop circulating } \\
\text { pump (50 pieces) }\end{array}$ & $\begin{array}{l}52^{\circ} 30^{\prime} \mathrm{N} \\
159^{\circ} 9^{\prime} \mathrm{E}\end{array}$ & $2.0-2.57$ & 0.0000045 & 16 & 0.00040 & 0.073 \\
\hline Area 9 & 1991 & Steam generator (5 pieces) & $\begin{array}{l}41^{\circ} 40^{\prime} \mathrm{N} \\
134^{\circ} 0^{\prime} \mathrm{E}\end{array}$ & $3.25-3.7$ & 0.000035 & 160 & 0.0030 & 0.56 \\
\hline \multirow[t]{2}{*}{ Area 10} & 1978 & Two submarine reactors & $\begin{array}{l}41^{\circ} 10^{\prime} \mathrm{N} \\
131^{\circ} 15^{\prime} \mathrm{E}\end{array}$ & $2.9-3.3$ & 0.59 & 180 & 19 & 200 \\
\hline & 1983 & Reactor lid (8 pieces) & $\begin{array}{l}41^{\circ} 40^{\prime} \mathrm{N} \\
131^{\circ} 26^{\prime} \mathrm{E}\end{array}$ & $2.9-3.3$ & 1.2 & 690 & 39 & 420 \\
\hline Total & & & & & 2.7 & 3,500 & 87 & 960 \\
\hline
\end{tabular}

${ }^{1}$ Information is that presented in the White Book (Yablokov et al., 1993).

${ }^{2}$ The exact depth of disposal was not specified. The depth presented is that associated with the area designation in the White Book.

${ }^{3}$ Inventory is based on the total activity at the time of disposal as presented in the White Book. 


\subsubsection{Sea of Japan and Pacific Ocean, East Coast of Kamchatka}

Reactor-related parts, such as primary loop circulating pumps, SGs, a reactor core plate, RPVs, and a reactor lid, reportedly were dumped as unenclosed objects in both the Pacific Ocean, east coast of Kamchatka (Area 8) and the Sea of Japan (Areas 9 and 10) (Yablokov et al., 1993). In the case of the reactor core plate, RPVs, and reactor lid, the radionuclides contained in each result from neutron activation of the SS or low-alloy steel from which they are constructed. For the primary loop circulating pumps and SGs, the radionuclides contained results from primary system corrosion. Whether activation or corrosion product, the long-lived radionuclides of consequence are the same: ${ }^{14} \mathrm{C},{ }^{60} \mathrm{Co},{ }^{59} \mathrm{Ni}$, and ${ }^{63} \mathrm{Ni}$. The difference is in the relative quantity of each.

Using information reported for the activation product inventories in the submarine PWRs without SNF that were dumped in the Kara Sea (Sivintsev, August 1994), the RAIG can estimate the activation product inventories in the reactor core plate, RPVs, and reactor lid. Conservatively, assuming that each reactor-related object was dumped a year after reactor shutdown, the RAIG can estimate the inventory from the product of the total reported activity at time of disposal and the average fraction of ${ }^{14} \mathrm{C},{ }^{60} \mathrm{Co},{ }^{59} \mathrm{Ni}$, and ${ }^{63} \mathrm{Ni}$ contained in the submarine PWRs without SNF at 1 year after shutdown. Simple radioactive decay then provides the inventory in 1994.

In a similar manner, the RAIG also can estimate the corrosion-product inventories in the primary loop circulating pumps and SGs. With one exception, the procedure is exactly the same as that for the activation products. The difference is the source of the fraction of ${ }^{14} \mathrm{C},{ }^{60} \mathrm{Co},{ }^{59} \mathrm{Ni}$, and ${ }^{63} \mathrm{Ni}$ contained in the corrosion products: a British calculation for a generic nuclear submarine one year after shutdown (House of Commons Defense Committee, 1990).

Table 2-8 presents the estimated 1994 activity of long-lived activation products in the reactorrelated unenclosed SRW dumpcd in the Sea of Japan and the Pacific Ocean, east coast of Kamchatka. Overall, the reactor-related unenclosed solid objects in 1994 contained about 4.6 TBq of radioactivity, with ${ }^{60} \mathrm{Co}$ and ${ }^{63} \mathrm{Ni}$ constituting $77 \%$ and $21 \%$ of the total, respectively. Furthermore, the reactor core plate in Area 8 and the reactor lid in Area 10 were the two greatest sources of this radioactivity. Figure 2-5 shows the disposal sites for the reactor-related uncnclosed solid objects in the Sea of Japan and the Pacific Ocean, east coast of Kamchatka.

\subsubsection{Sea of Okhotsk}

Between 1987 and 1990, scientists conducted extensive annual surveys of the area in which the ${ }^{40} \mathrm{Sr}$ RTG was lost (Danilyan and Vysotsky, 1995), but they located no RTG and observed no detectable activity. Assuming the reported strength of the ${ }^{90} \mathrm{Sr}$ RTG source $(13,000 \mathrm{TBq})$ to be that at the time of its loss near the Sakhalin Island coast in 1987, the RAIG assigned the 1994 activity a concentration of $11,000 \mathrm{TBq}$. 


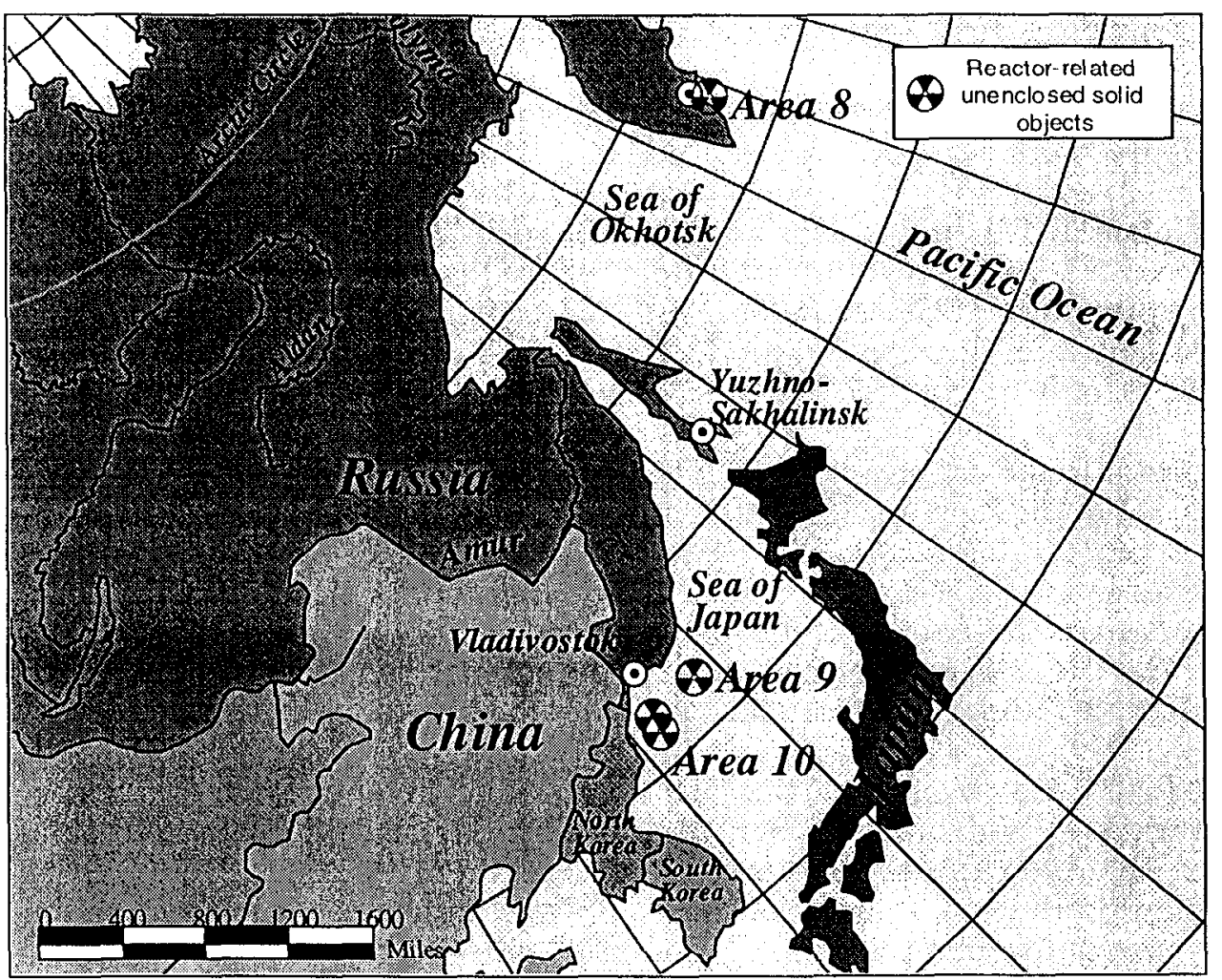

Figure 2-5. Disposal sites for reactorrelated unenclosed solid objects in the Sea of Japan and the Pacific Ocean, east coast of Kamchatka.

\subsubsection{West Siberian Basin}

Bradley and Jenquin (1995) have prepared a review of the nuclear inventories for the major sites within the West Siberian Basin. Table 2-9 summarizes estimates of the total activities for the sites and includes a qualitative assessment of the likelihood of release from a given source to an adjacent river. Deep-well injection of LRW accounts for $85 \%$ of the total radionuclide inventory, and given the geologic isolation of these injected wastes, they are not considered to be available for riverine transport. The remaining waste sources are basically associated with existing surface reservoirs and marshes that contain elevated levels of dissolved radionuclides. The inventories associated with sites categorized in Table 2-9 as having some potential for migration are as follows:

- $4,800,000 \mathrm{TBq}$ (for Tomsk-Tom River);

- 4,900,000 TBq (for Mayak-Techa River);

- 5,800 TBq (Krasnoyarsk-Yenisey River); and

- 3,300 TBq (Semipalatinsk-Irtysh River). 
Table 2-9. Summary of the total radionuclide inventories for nuclear wastes at Tomsk 7, Krasnoyarsk 26, and Mayak (from Bradley and Jenquin, 1995).

\begin{tabular}{|c|c|c|c|}
\hline Site/Source & $\begin{array}{l}\text { Current } \\
\text { Activity, } \mathrm{TBq} \\
\text { (\% of total) } \\
\end{array}$ & $\begin{array}{c}\text { River } \\
\text { Affected }\end{array}$ & Status \\
\hline Tomsk-7/Injection & $\begin{array}{c}3.7 \times 10^{7} \\
(58.0 \%)\end{array}$ & Tom-Ob & $\begin{array}{l}\text { Contaminant migration reported to be } \\
\text { minimal, because of depth of discharges, } \\
\text { contamination of Tom-Ob unlikely in near } \\
\text { future }\end{array}$ \\
\hline Krasnoyarsk-26/Injection & $\begin{array}{l}1.7 \times 10^{7} \\
(26.7 \%)\end{array}$ & Yenisey & (same as above) \\
\hline Tomsk-7/Reservoirs & $\begin{array}{l}4.8 \times 10^{6} \\
(7.5 \%)\end{array}$ & Tom- $\mathrm{Ob}$ & Unknown, some migration possible \\
\hline Mayak/Reservoir 9 & $\begin{array}{l}4.4 \times 10^{6} \\
(6.9 \%)\end{array}$ & Techa-Ob & Already migrating into river system \\
\hline Mayak/Solid Waste & $\begin{array}{l}4.4 \times 10^{6} \\
(0.7 \%)\end{array}$ & Techa-Ob & Likely marginal contributor \\
\hline Mayak/Reservoir 17 & $\begin{array}{l}74,000 \\
(0.1 \%)\end{array}$ & Techa-Ob & Already migrating into river system \\
\hline Mayak/Techa Reservoirs & $\begin{array}{c}7,400 \\
(<0.01 \%)\end{array}$ & Techa-Ob & Already migrating into river system \\
\hline $\begin{array}{l}\text { Mayak/Production } \\
\text { Reactors }\end{array}$ & $\begin{array}{c}4,900 \\
(<0.01 \%)\end{array}$ & Techa-Ob & Already migrating into river system \\
\hline $\begin{array}{l}\text { Krasnoyarsk-26/ } \\
\text { Production Reactors }\end{array}$ & $\begin{array}{c}3,900 \\
(<0.01 \%)\end{array}$ & Yenisey & $\begin{array}{l}\text { Inventory in Yenisey River and has } \\
\text { migrated at least } 1,500 \mathrm{~km}\end{array}$ \\
\hline Semipalatinsk & $\begin{array}{c}3,300 \\
(<0.01 \%)\end{array}$ & Irtysh-Ob & $\begin{array}{l}\text { Derived from weapons testing, likely } \\
\text { migrating into river systems }\end{array}$ \\
\hline $\begin{array}{l}\text { Krasnoyarsk-26/ } \\
\text { Reservoirs }\end{array}$ & $\begin{array}{c}1,900 \\
(<0.01 \%)\end{array}$ & Yenisey & $\begin{array}{l}\text { Unknown, some migration to Yenisey } \\
\text { possible }\end{array}$ \\
\hline $\begin{array}{l}\text { Tomsk-7/Production } \\
\text { Reactors }\end{array}$ & $\begin{array}{c}1,400 \\
(<0.01 \%)\end{array}$ & Tom-Ob & $\begin{array}{l}\text { Inventory in Tom River and likely } \\
\text { migrating }\end{array}$ \\
\hline Mayak/Tank Explosion & $\begin{array}{c}1,600 \\
(<0.01 \%)\end{array}$ & Techa-Ob & $\begin{array}{l}\text { Small contributor to Techa River } \\
\text { contamination }\end{array}$ \\
\hline Ob-Yenisey Rivers & $\begin{array}{c}1,200 \\
(<0.01 \%)\end{array}$ & Kara Sea & $\begin{array}{l}\text { Amount of } \mathrm{Sr}^{90}(1,100 \mathrm{Tbq}) \text { and } \mathrm{Cs}^{137} \text { that } \\
\text { has migrated to the Kara Sea from the West } \\
\text { Siberian Basin }\end{array}$ \\
\hline Mayak/Wind Erosion & $\begin{array}{c}22 \\
(<0.01 \%)\end{array}$ & Techa-Ob & Likely marginal contributor \\
\hline $\begin{array}{l}\text { Nuclear-Power-Reactor } \\
\text { Operations }\end{array}$ & $\begin{array}{c}3 \\
(<0.01 \%) \\
\end{array}$ & $\mathrm{Ob}$ & $\begin{array}{l}\text { Discharges to marshes at Beloyarsk reactor } \\
\text { site, unlikely contributor }\end{array}$ \\
\hline
\end{tabular}


Although estimates of the total radionuclide inventories available for riverine transport are useful in determining the relative magnitudes of the different sources, the actual radionuclide composition of the wastes must be characterized to assess the potential risks associated with those sources. In this regard, little is known about the radionuclide composition of the LRWs stored at Tomsk or Krasnoyarsk, although they are probably similar to the wastes at the Mayak facility. I'able 2-10 presents the inventories of ${ }^{90} \mathrm{Sr}$ and ${ }^{137} \mathrm{C}$ s that are associated with the LRWS stored in the lakes and reservoirs at Mayak (see Figure 2-6). These inventories do not reflect the radioactivity in the reservoir sediments. The largest inventories are in Lake Karachai (also referred to as Reservoir 9), which poses no direct threat for an inadvertent discharge to the Techa River, but the transport of radionuclides in groundwater from the aquifer beneath the lake is a source of long-term discharge to the Techa River. Lake Kyzyltash (Reservoir 2) drains to Reservoir 3, but there is apparently no threat of a catastrophic release from the lake, as there is a natural shoreline serving as a barrier. The wastewater reservoirs that constitute a threat to the Techa River are primarily Reservoirs 3,4,10,11, and 17. The dominant radionuclide in those particular reservoirs is ${ }^{90} \mathrm{Sr}$, with an estimated inventory of $9,200 \mathrm{TBq}$, which is about a factor of 100 higher than the inventory of ${ }^{137} \mathrm{Cs}$. Tritiated water represents about 2,500 TBq of the total inventory (from Bradley and Jenquin, 1995). Measured concentrations of ${ }^{90} \mathrm{Sr}$ and ${ }^{137} \mathrm{Cs}$ in the Techa River below Reservoir 11 show the same relationship between those two nuclides in the radioactive liquid wastes, that is, ${ }^{90} \mathrm{Sr}$ levels are about a factor of 100 greater than those for ${ }^{137} \mathrm{Cs}$ (see Trapeznikov et al., 1993).

Table 2-10. Inventories of ${ }^{90} \mathrm{Sr}$ and ${ }^{137} \mathrm{Cs}$ dissolved in wastewaters stored in reservoirs associated with Mayak facility (from Bradley and Jenquin, 1995).

\begin{tabular}{|c|c|c|c|c|c|}
\hline \multirow[b]{2}{*}{ Reservoir } & \multirow[b]{2}{*}{$\begin{array}{l}\text { Volume } \\
\mathrm{m}^{3}\end{array}$} & \multicolumn{2}{|c|}{${ }^{90} \mathrm{Sr}$} & \multicolumn{2}{|c|}{${ }^{137} \mathrm{Cs}$} \\
\hline & & $\begin{array}{c}\text { Concentration } \\
\mathrm{Bq} / \mathrm{m}^{3}\end{array}$ & $\begin{array}{c}\text { Inventory } \\
\mathrm{Bq}\end{array}$ & $\begin{array}{c}\text { Concentration } \\
\mathrm{Bq} / \mathrm{m}^{3}\end{array}$ & $\begin{array}{c}\text { Inventory } \\
\mathrm{Bq}\end{array}$ \\
\hline $2^{a}$ & $8.4 \times 10^{7}$ & $4.1 \times 10^{5}$ & $3.4 \times 10^{13}$ & $1.7 \times 10^{5}$ & $1.4 \times 10^{13}$ \\
\hline 3 & $7.8 \times 10^{5}$ & $5.9 \times 10^{7}$ & $4.6 \times 10^{13}$ & $7.4 \times 10^{6}$ & $5.8 \times 10^{12}$ \\
\hline 4 & $4.2 \times 10^{6}$ & $6.3 \times 10^{6}$ & $2.6 \times 10^{13}$ & $2.7 \times 10^{6}$ & $1.1 \times 10^{13}$ \\
\hline 6 & $1.8 \times 10^{7}$ & $1.4 \times 10^{4}$ & $2.4 \times 10^{11}$ & $7.4 \times 10^{2}$ & $1.3 \times 10^{10}$ \\
\hline $9 b$ & $4.0 \times 10^{5}$ & $6.3 \times 10^{10}$ & $2.5 \times 10^{16}$ & $4.4 \times 10^{11}$ & $1.8 \times 10^{17}$ \\
\hline 10 & $7.7 \times 10^{7}$ & $1.3 \times 10^{7}$ & $9.9 \times 10^{14}$ & $3.2 \times 10^{5}$ & $2.4 \times 10^{13}$ \\
\hline 11 & $2.2 \times 10^{8}$ & $1.9 \times 10^{6}$ & $4.1 \times 10^{14}$ & $7.4 \times 10^{2}$ & $1.6 \times 10^{11}$ \\
\hline 17 & $3.0 \times 10^{5}$ & $2.6 \times 10^{10}$ & $3.9 \times 10^{15}$ & $1.5 \times 10^{8}$ & $2.2 \times 10^{13}$ \\
\hline
\end{tabular}




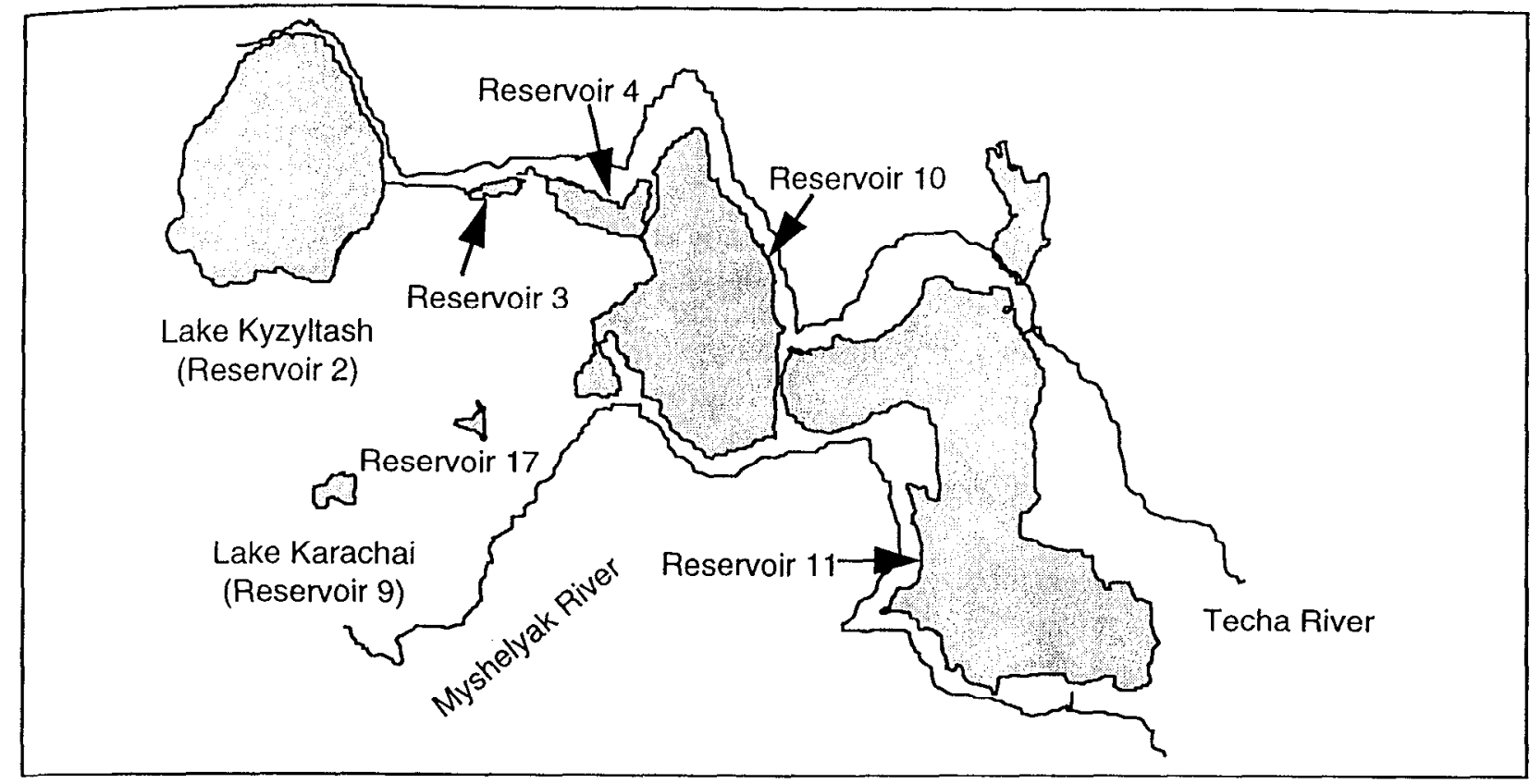

Figure 2-6. The reservoirs constructed to prevent Techa River contamination from liquid radioactive discharges from the Mayak operation.

\subsection{Radionuclide Screening}

The nuclear wastes dumped into the Arctic and Pacific Oceans by the FSU, and those currently entering or postulated to enter through the Russian river systems, contain a variety of radionuclides. Some of these radionuclides, though, are far more important than others in terms of their potential radiological impact. Therefore, to provide a focus for our assessment of the risks posed by the various nuclear wastes, the RAIG performed a screening analysis to identify those radionuclides that could pose the greatest potential risks, and conversely, to identify those that pose the least risk. The screening anaiysis was divided into two parts, the first addressing the Kara Sea as a source area (for disposed wastes and riverine influxes from Russian rivers) and the second part, the wastes dumped in the northwest Pacific Ocean.

\subsubsection{Kara Sea and West Siberian Sources}

The relative importance of each radionuclide present in the nuclear wastes dumped in the Kara Sea and at nuclear facilities in the Siberian Basin is a function of several factors. The first is the overall quantity, or inventory, of each radionuclide. The more of any radionuclide there is in the Arctic Ocean, the greater its potential importance as a radiological hazard. The second factor is the radiological half-life of each radionuclide. If a radionuclide decays quickly, it will be less important than one that remains radioactive for a longer time. The third factor is the solubility of the radionuclides in seawater; relatively insoluble radionuclides such as plutonium and americium adsorb to suspended particulate matter and are scavenged from the water column as the particles settle to the sea bottom. Particle scavenging of such nuclides, therefore, reduces their mobility in the marine environment and, subsequently, potential human exposures. A fourth 
factor is the bioavailability of the radionuclides, that is, the effectiveness by which a given radionuclide is absorbed or taken up into marine organisms that are part of food chains. Finally, the human metabolism and retention of radionuclides, and their dosimetry, are also important factors.

The RAIG has based the radionuclide screening methodology on the estimation of potential human population doses resulting from the long-term ingestion of fish, marine mammals, and mollusks contaminated as result of potential radionuclide releases to the Arctic Ocean. For the $i$ th radionuclide, the collective (population) dose at time $t$ is

$\mathrm{D}_{i}(t)=\operatorname{Pop}\left[\sum_{j=1}^{n} \mathrm{I}_{i} \times \mathrm{BCF}_{i j}\right] \times \mathrm{DCF}_{i} \times C_{i}(t)$

where

$\mathrm{D}_{i}(t)=$ annual population dose for the $i$ th radionuclide in year $t$, person-Sv/yr;

$\mathrm{I}_{j} \quad=$ annual average intake of the $j$ th seafood item, $\mathrm{kg} / \mathrm{yr}$;

Pop = number of individuals consuming contaminated seafood, persons;

$\mathrm{BCF}_{i j}=$ bioconcentration factor of the $i$ th radionuclide for the $j$ th seafood item, $\mathrm{m}^{3} / \mathrm{kg}$;

$\mathrm{DCF}_{i}=$ dose-conversion factor for ingestion of the $i$ th radionuclide, $\mathrm{Sv} / \mathrm{Bq} ;$ and

$\mathrm{C}_{i}(t)=$ time-varying concentration of the $i$ th radionuclide, $\mathrm{Bq} / \mathrm{m}^{3}$.

For screening analysis, the RAIG can estimate the time-varying concentration of a given radionuclide by assuming that its estimated inventory is instantaneously released to the Arctic Ocean, with no credit taken for containment properties of the waste forms. This is clearly a conservative assumption; however, it does allow for a dose-based ranking that uses the estimated radionuclide inventories. The time-varying concentration of a radionuclide in the Arctic Ocean at time $t$ after an instantaneous release is calculated as

$\mathrm{C}_{i}(t)=\frac{\mathrm{S}}{\mathrm{V}} \exp \left[-\left(\lambda_{d}^{i}+\lambda_{w}+\lambda_{s}^{i}\right) t\right]$

where

$\lambda_{d}^{i}=\frac{0.693}{\mathrm{~T}_{1 / 2}}$

$\lambda_{w}=\frac{\mathrm{W}}{\mathrm{V}}$, 
$\lambda_{\mathrm{s}}^{i}=\frac{\mathrm{K}_{\mathrm{d}}^{i} \mathrm{~F}_{\mathrm{s}}}{\mathrm{h}\left(\mathrm{I}+\mathrm{K}_{\mathrm{d}}^{i} \mathrm{P}\right)}$

and

$$
\begin{aligned}
& \mathrm{C}_{i}(t)=\text { concentration of the } i \text { th radionuclide at time } t, \mathrm{~Bq} / \mathrm{m}^{3} ; \\
& \mathrm{S}_{\mathrm{i}}=\text { inventory of the } i \text { th radionuclide at time } 0, \mathrm{~Bq} ; \\
& \mathrm{V}=\text { volume of Arctic Ocean, } \mathrm{m}^{3} ; \\
& \lambda_{d}^{i}=\text { radioactive decay rate of the } i \text { th radionuclide, } 1 / \mathrm{yr} ; \\
& l_{w}=\text { loss rate constant for water exchange, } 1 / \mathrm{yr} ; \\
& l_{s}^{i}=\text { loss rate constant for the } i \text { th radionuclide from sedimentation, } 1 / \mathrm{yr} ; \\
& \mathrm{T}_{1 / 2}=\text { half-life for radioactive decay, } \mathrm{y} ; \\
& \mathrm{W}=\text { exchange rate of water through the Arctic Ocean, } \mathrm{m}^{3} / \mathrm{yr} ; \\
& \mathrm{K}_{\mathrm{d}}^{\mathrm{i}}=\text { sediment } / \text { water distribution coefficient of the } i t \mathrm{th} \text { radionuclide, } \mathrm{m}^{3} / \mathrm{kg} ; \\
& \mathrm{F}_{\mathrm{s}}=\text { sedimentation rate, } \mathrm{kg} / \mathrm{m}^{2}-\mathrm{y} ; \\
& \mathrm{P}=\text { mass loading of particulate matter in water, } \mathrm{kg} / \mathrm{m}^{3} ; \text { and } \\
& \mathrm{h}=\text { average depth of the Arctic Ocean, m. }
\end{aligned}
$$

Integrating Eq. 2-1 from the time of release to $t=\infty$ obtains an estimate of the population dose resulting from long-term dietary exposures (composed of two dietary items: fish/marine mammals and shellfish) to the $i$ th radionuclide (UNSCEAR, 1977), or

$$
\int_{0}^{\infty} D_{i}(t) \mathrm{dt}=\operatorname{Pop}\left[\sum_{i=1}^{2} \mathrm{I}_{j} \mathrm{BCF}_{i j}\right] \operatorname{DCF}_{\bar{V}}^{S_{i}}\left(\lambda_{d}^{i}+\lambda_{w}+\lambda_{s}^{i}\right)^{-1}
$$

A ranking formula can now be developed that expresses the relative importance of each nuclide as percent of the total population dose for all nuclides, or

$$
\operatorname{Rank}_{i}(\%)=\frac{100\left[\sum_{j=1}^{2} \mathrm{IjCF}_{i j}\right] \operatorname{SiDCF}_{i}\left(\lambda_{d}^{i}+\lambda_{w}+\lambda_{s}^{i}\right)^{-1}}{\sum_{i=1}^{n}\left[\sum_{j=1}^{2} \mathrm{I}_{j} \mathrm{BCF}_{i j}\right] \operatorname{SiDCF}_{i}\left(\lambda_{d}^{i}+\lambda_{w}+\lambda_{s}^{i}\right)^{-1}}
$$


Note that Eq. 2-7 has been simplified; both the population and water-volume terms were canceled.

The loss-rate constant for water exchange is $\lambda_{w}$ (Eq. 2-4) equal to the exchange rate of water from the ocean compartment divided by the compartmental volume. The volume of the Arctic Ocean is about $1.9 \times 10^{16} \mathrm{~m}^{3}$ and its average depth is $1,000 \mathrm{~m}$. Estimates of the combined water exchanges from the North Atlantic and Pacific Oceans range from 2.9 to $15 \times 10^{6} \mathrm{~m}^{3} / \mathrm{s}$ (or $3.2 \times 10^{13} \mathrm{~m}^{3} / \mathrm{yr}$ ). For example, Ostlund and Hut (1984) used data on isotopic tracers to estimate an oceanic exchange rate of $9.0 \times 10^{13} \mathrm{~m}^{3} / \mathrm{yr}$, whereas Nielsen (1995) used an ocean circulation model to estimate a water exchange rate of nearly $4.8 \times 10^{14} \mathrm{~m}^{3} / y \mathrm{r}$. Aagaard and Greisman (1975) estimated an exchange of $9.4 \times 10^{6} \mathrm{~m}^{3} / \mathrm{s}$, based largely on current data (see Section 3 for additional discussion of water exchange rates among the Arctic Seas.). Assuming that the $2.9 \times 10^{6}$ and $15 \times 10^{6} \mathrm{~m}^{3} / \mathrm{s}$ values represent lower and upper bounds of the exchange rates, then the geometric mean value is $6.6 \times 10^{6} \mathrm{~m}^{3} / \mathrm{s}$. Therefore, $\lambda_{w}$ is $0.011 / \mathrm{yr}$.

The decline in the concentration of a radionuclide in water from the deposition of sediments containing adsorbed radionuclides is controlled by both the sedimentary characteristics of the water column (mass loading particles and their average settling rate) and the sediment-water distribution of a radionuclide (i.e., as the partition coefficient increases, the loss via sedimentation increases). The loss-rate constant for a highly sorptive nuclide such as ${ }^{239} \mathrm{Pu}$ resulting from particle settling, $\lambda_{\mathrm{s}}$ (Eq. 2-5), is $9.1 \times 10^{-4} / \mathrm{yr}$ or a factor of 12 lower than the rate constant for volumetric exchange of water through the Arctic Ocean (using a $K_{d}$ of $100 \mathrm{~m}^{3} / \mathrm{kg}$, an average depth of $1,000 \mathrm{~m}$ for the Arctic Ocean, and a sediment loading and deposition rate of $0.001 \mathrm{~kg} / \mathrm{m}^{3}$ and $0.01 \mathrm{~kg} / \mathrm{m}^{2}$-yr, respectively [Nielsen, 1995]). Table $2-11$ summarizes the $\mathrm{K}_{\mathrm{d}}$ values used to represent the nuclides (from IAEA Technical Report 247, [IAEA, 1985]) and Table 2-12 presents the rate constants for radioactive decay, sedimentation, and water exchange for each of the radionuclides. The remaining terms that need to be estimated for the ranking formula (Eq. 27) are the dose-conversion factors (DCFs) for each radionuclide, the bioconcentration factors (BCFs) for fish/marine mammals and mollusks, and the related consumption rates. Table 2-11 contains the DCFs and BCFs used in the screening analysis. For the purposes of the screening-level analysis, the RAIG also has used the default BCF values from IAEA Technical Report 247 (IAEA, 1985) (refer to Section 4 for an analysis of BCFs related marine species from Arctic waters), while the DCFs are from ICRP (1994) and Eckerman (1988). To represent the elevated ingestion of seafoods in subsistence diets of Arctic populations, the RAIG selected an ingestion rate of $200 \mathrm{~kg} / \mathrm{yr}$, based on the range of intakes summarized in Section 6 . An ingestion rate of $1 \mathrm{~kg} / \mathrm{yr}$ was used to represent the ingestion of shellfish (UNSCEAR, 1977). This reduced intake is consistent with the limited use of shellfish in subsistence diets.

The initial screening analysis of the Kara Sea source region considered only the inventories of the various radionuclides for the nuclear wastes disposed in the Kara Sea listed in Table 2-7. Results of that analysis are shown in Table 2-12. The principal radionuclides of potential concern are ${ }^{239} \mathrm{Pu},{ }^{241} \mathrm{Am}$, and ${ }^{137} \mathrm{Cs}$. These nuclides represent $86 \%$ of the potential population dose, but account for only $39 \%$ of the total radionuclide inventory (excluding the short-lived decay products of ${ }^{137} \mathrm{Cs}$ and ${ }^{90} \mathrm{Sr}$ ). A second set of nuclides consisting of ${ }^{60} \mathrm{Co},{ }^{63} \mathrm{Ni}$, ${ }^{90} \mathrm{Sr}$, and ${ }^{238} \mathrm{Pu}$ represent another $13 \%$ of the potential population dose. However, when the large inventories of ${ }^{90} \mathrm{Sr}$ in the reservoirs at Mayak are considered (5,000 TBq in Reservoirs 10, 11, and 17 that could discharge to the $\mathrm{Ob}$ River system), this nuclide becomes more important than the activation products ${ }^{60} \mathrm{Co}$ and ${ }^{63} \mathrm{Ni}$. Consequently, ${ }^{239} \mathrm{Pu},{ }^{241} \mathrm{Am},{ }^{90} \mathrm{Sr}$, and ${ }^{137} \mathrm{Cs}$ amount to $90 \%$ of the screening dose recalculated using the higher inventories for ${ }^{90} \mathrm{Sr}$. The RAIG focused on these four nuclides because they collectively represent the greatest contributors to potential doses. Moreover, the activation products ${ }^{60} \mathrm{Co}$ and ${ }^{63} \mathrm{Ni}$ are incorporated within metal matrices in reactor components and are gradually 
released as corrosion takes place. The actinides and fission products are associated with the nuclear fuel assemblies that are presumably more susceptible to dispersal in seawater. To examine the sensitivity of the screening model to the rate constants for sedimentation, the RAIG set the $K_{d}$ values of all the radionuclides to zero. This adjustment, however, did not alter the relative ranks of the screening set, although the long-lived actinides ${ }^{239} \mathrm{Pu}$ and ${ }^{241} \mathrm{Am}$ accounted for more of the total population dose. An increase in the water exchange rate also did not affect the ranking of the various nuclides.

\subsubsection{Northwest Pacific Ocean Sources}

The screening analysis of radionuclides associated with the radioactive wastes dumped in the Northwest Pacific Ocean is restricted to the activation products associated with reactor components (disposal sites in the Sea of Japan and the East Coast of Kamchatka) and a radioisotope thermoelectric generator fueled by ${ }^{90} \mathrm{Sr}$. There is no information on the true radionuclide inventories associated with non-reactor-related solid wastes, but this is not surprising because radiological measurements of such wastes prior to disposal are usually very limited or nonexistent. As a means of determining whether the releases of the activation products from reactor components constitute a viable threat to Alaska, the RAIG develops simple, screening-level estimates of the resulting concentrations of the radionuclides dissolved in a volume of water that is equivalent to that of the Bering Sea (i.e., $3.6 \times 10^{15} \mathrm{~m}^{3}$ ). This clearly is a conservative approach because it neglects the dispersion that would occur as the radionuclides are transported from the wastes sources to the Bering Sea. Nevertheless, if the predicted concentrations are insignificant under these conditions, there is no need to conduct more detailed assessments of the sources.

The primary nuclides associated with the reactor-related unenclosed solid objects are the activation products consisting of ${ }^{14} \mathrm{C},{ }^{60} \mathrm{Co},{ }^{59} \mathrm{Ni}$, and ${ }^{63} \mathrm{Ni}$. Releases of these radionuclides will occur over time through the corrosion of the construction materials. The primary activation product listed in Table 2-8 for Areas 8, 9, and 10 is ${ }^{60} \mathrm{Co}$, which also has the highest dose per unit of radioactivity ingested of the four activation products. Therefore, for the purposes of the screening analysis, the RAIG will use this nuclide to assess the radiological hazard of the reactor-related wastes. The estimated inventory of ${ }^{60} \mathrm{Co}$ as well as predictions of the corrosion-driven release rates will serve as the basis of the screening-level estimates of ${ }^{60} \mathrm{Co}$ in seawater. The screeninglevel analysis for the RTG will be based on its inventory of ${ }^{90} \mathrm{Sr}$. The annual dose attributable to consumption of fish/marine mammals from the hypothetical contamination of a volume of water equivalent to the Bering Sea is given as

$\mathrm{D}_{i}=\mathrm{I}_{i} \mathrm{BCF}_{i} \mathrm{DCF}_{i} \mathrm{C}_{i}$,

where

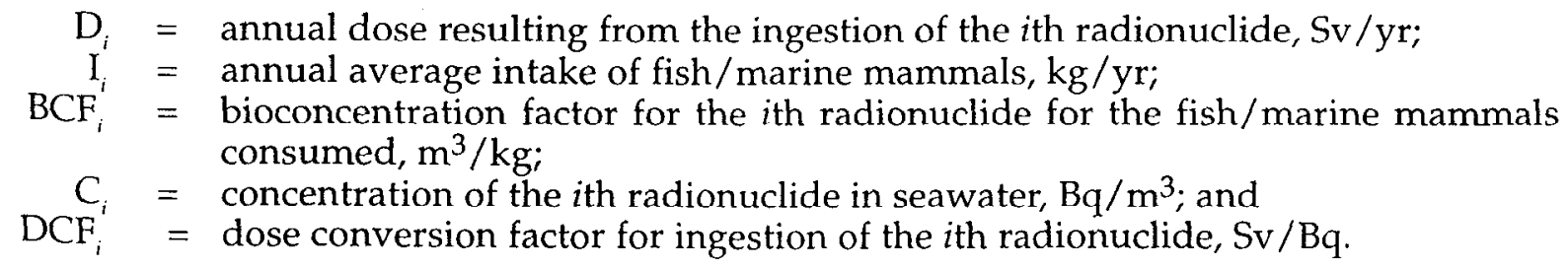


Table 2-11. Input parameters for use in the dose-based screening analysis of radionuclides. The sediment-water distribution coefficients $\left(K_{d}\right)$ and bioconcentration factors $(B C F)$ values are from IAEA (1985), while the dose conversion factors (DCFs) are from ICRP (1994) and Eckerman et al. (1988).

\begin{tabular}{|c|c|c|c|c|c|}
\hline \multirow{3}{*}{ Radionuclide } & \multirow[b]{2}{*}{ Half-Life } & \multirow[b]{2}{*}{$\mathrm{K}_{\mathrm{d}}$} & \multirow[b]{2}{*}{ DCF } & \multicolumn{2}{|c|}{ Bioconcentration Factors } \\
\hline & & & & Fish & Mollusk \\
\hline & $y$ & $\mathrm{~m}^{3} / \mathrm{kg}$ & $\mathrm{Sv} / \mathrm{Bq}$ & \multicolumn{2}{|c|}{$\mathrm{m}^{3} / \mathrm{kg}$} \\
\hline${ }^{241} \mathrm{Am}$ & 432 & 2,000 & $2.1 \times 10^{-7^{a}}$ & 0.05 & 20 \\
\hline${ }^{239} \mathrm{Pu}$ & 24,100 & 100 & $2.5 \times 10^{-7^{a}}$ & 0.04 & 3 \\
\hline${ }^{238} \mathrm{Pu}$ & 88 & 100 & $2.3 \times 10^{-7^{a}}$ & 0.04 & 3 \\
\hline${ }^{137} \mathrm{Cs}$ & 30 & 3 & $1.4 \times 10^{-8^{\mathrm{a}}}$ & 0.1 & 0.03 \\
\hline${ }^{60} \mathrm{Co}$ & 5 & 200 & $3.4 \times 10^{-9^{a}}$ & 1 & 5 \\
\hline${ }^{63} \mathrm{Ni}$ & 96 & 100 & $1.5 \times 10^{-10^{\mathrm{a}}}$ & 1 & 2 \\
\hline${ }^{90} \mathrm{Sr}$ & 29 & 1 & $2.8 \times 10^{-8^{a}}$ & 0.002 & 0.001 \\
\hline${ }^{152} \mathrm{Eu}$ & 13 & 500 & $1.8 \times 10^{-9^{\mathrm{h}}}$ & 0.3 & 7 \\
\hline${ }^{154} \mathrm{Eu}$ & 9 & 500 & $2.6 \times 10^{-9^{b}}$ & 0.3 & 7 \\
\hline${ }^{14} \mathrm{C}$ & 5,730 & 2 & $5.8 \times 10^{-10^{\mathrm{a}}}$ & 20 & 20 \\
\hline${ }^{59} \mathrm{Ni}$ & 75,000 & 100 & $6.3 \times 10^{-11^{\mathrm{a}}}$ & 1 & 2 \\
\hline${ }^{151} \mathrm{Sm}$ & 90 & 2,000 & $1.1 \times 10^{-10^{\mathrm{b}}}$ & 0.5 & 5 \\
\hline${ }^{99} \mathrm{Tc}$ & 213,000 & 0 & $6.4 \times 10^{-10^{a}}$ & 0.03 & 1 \\
\hline${ }^{147} \mathrm{Pm}$ & 3 & 2,000 & $2.8 \times 10^{-10^{b}}$ & 0.5 & 5 \\
\hline${ }^{155} \mathrm{Eu}$ & 5 & 500 & $4.1 \times 10^{-10^{b}}$ & 0.3 & 7 \\
\hline${ }^{125} \mathrm{Sb}$ & 3 & 1 & $7.6 \times 10^{-10^{b}}$ & 0.4 & 0.2 \\
\hline${ }^{205} \mathrm{~Pb}$ & $14,000,000$ & 200 & $4.4 \times 10^{-10^{b}}$ & 0.2 & 1 \\
\hline${ }^{207} \mathrm{Bi}$ & 38 & 1 & $1.5 \times 10^{-9^{b}}$ & $0.4^{\mathrm{c}}$ & $0.2^{\mathrm{c}}$ \\
\hline${ }^{208} \mathrm{Bi}$ & 368,000 & 1 & $3.4 \times 10^{-9^{d}}$ & $0.4^{\mathrm{c}}$ & $0.2^{\mathrm{c}}$ \\
\hline${ }^{210} \mathrm{mBi}$ & $3,000,000$ & 1 & $2.6 \times 10^{-8^{b}}$ & $0.4^{\mathrm{c}}$ & $0.2^{c}$ \\
\hline${ }^{129} I$ & $15,700,000$ & 0 & $1.1 \times 10^{-7^{\mathrm{a}}}$ & 0.01 & 0.01 \\
\hline${ }^{3} \mathrm{H}$ & 12 & 0 & $1.8 \times 10^{-11^{\mathrm{a}}}$ & 0.001 & 0.001 \\
\hline
\end{tabular}

a ICRP (1994)

b Eckerman et al. (1988).

c Bismuth (Bi) should have properties similar to those of antimony $(\mathrm{Sb})$ based on their position in the Periodic Chart. The RAIG has therefore used the $K_{d}$ and BCF values of antimony to represent those of bismuth.

d A dose-conversion factor was not available for ${ }^{208} \mathrm{Bi}$, so the RAIG used the DCF of ${ }^{60} \mathrm{Co}$ because its gammaray energy is comparable to that of $208 \mathrm{Bi}$. 
Table 2-12. Results of the dose-based ranking of the radionuclides present in the Kara Sea dump sites.

\begin{tabular}{|c|c|c|c|c|c|}
\hline & & \multicolumn{4}{|c|}{ Rate Constants } \\
\hline & & $\begin{array}{c}\text { Radioactive } \\
\text { Decay }\end{array}$ & $\begin{array}{c}\text { Water } \\
\text { Exchange }\end{array}$ & & $\begin{array}{c}\text { Particle } \\
\text { Scavenging }\end{array}$ \\
\hline Radionuclide & $\begin{array}{c}\text { Inventory } \\
\mathrm{Bq}\end{array}$ & & $1 / \mathrm{yr}$ & & Ranking (\%) \\
\hline $137 \mathrm{Cs}$ & $1.0 \times 10^{15}$ & $2.3 \times 10^{-2}$ & $1.1 \times 10^{-2}$ & $3.0 \times 10^{-5}$ & 68 \\
\hline${ }^{239} \mathrm{Pu}$ & $6.2 \times 10^{12}$ & $2.9 \times 10^{-5}$ & $1.1 \times 10^{-2}$ & $9.1 \times 10^{-4}$ & 11 \\
\hline${ }^{241} \mathrm{Am}$ & $8.3 \times 10^{12}$ & $1.6 \times 10^{-3}$ & $1.1 \times 10^{-2}$ & $6.7 \times 10^{-3}$ & 7.5 \\
\hline${ }^{60} \mathrm{Co}$ & $1.4 \times 10^{14}$ & $1.3 \times 10^{-1}$ & $1.1 \times 10^{-2}$ & $1.7 \times 10^{-3}$ & 4.7 \\
\hline${ }^{63} \mathrm{Ni}$ & $3.5 \times 10^{14}$ & $7.2 \times 10^{-3}$ & $1.1 \times 10^{-2}$ & $9.1 \times 10^{-4}$ & 4.2 \\
\hline${ }^{90} \mathrm{Sr}$ & $9.5 \times 10^{14}$ & $2.4 \times 10^{-2}$ & $1.1 \times 10^{-2}$ & $1.0 \times 10^{-5}$ & 2.5 \\
\hline${ }^{238} \mathrm{Pu}$ & $1.6 \times 10^{12}$ & $7.9 \times 10^{-3}$ & $1.1 \times 10^{-2}$ & $9.1 \times 10^{-4}$ & 1.5 \\
\hline${ }^{152 \mathrm{Eu}}$ & $6.0 \times 10^{13}$ & $5.2 \times 10^{-2}$ & $1.1 \times 10^{-2}$ & $3.3 \times 10^{-3}$ & 0.58 \\
\hline${ }^{154} \mathrm{Eu}$ & $1.1 \times 10^{13}$ & $7.9 \times 10^{-2}$ & $1.1 \times 10^{-2}$ & $3.3 \times 10^{-3}$ & 0.11 \\
\hline${ }^{14} \mathrm{C}$ & $1.6 \times 10^{11}$ & $1.2 \times 10^{-4}$ & $1.1 \times 10^{-2}$ & $2.0 \times 10^{-5}$ & 0.28 \\
\hline${ }^{59} \mathrm{Ni}$ & $8.6 \times 10^{12}$ & $9.2 \times 10^{-6}$ & $1.1 \times 10^{-2}$ & $9.1 \times 10^{-4}$ & 0.07 \\
\hline${ }^{151} \mathrm{Sm}$ & $2.4 \times 10^{13}$ & $7.7 \times 10^{-3}$ & $1.1 \times 10^{-2}$ & $6.7 \times 10^{-3}$ & 0.03 \\
\hline $210 \mathrm{mBi}$ & $3.4 \times 10^{9}$ & $2.3 \times 10^{-7}$ & $1.1 \times 10^{-2}$ & $1.0 \times 10^{-5}$ & 0.01 \\
\hline${ }^{208} \mathrm{Bi}$ & $6.2 \times 10^{9}$ & $1.9 \times 10^{-6}$ & $1.1 \times 10^{-2}$ & $1.0 \times 10^{-5}$ & $<0.01$ \\
\hline${ }^{99} \mathrm{Tc}$ & $2.8 \times 10^{11}$ & $3.3 \times 10^{-6}$ & $1.1 \times 10^{-2}$ & $1.0 \times 10^{-6}$ & $<0.01$ \\
\hline${ }^{147} \mathrm{Pm}$ & $2.4 \times 10^{12}$ & $2.6 \times 10^{-1}$ & $1.1 \times 10^{-2}$ & $6.7 \times 10^{-3}$ & $<0.01$ \\
\hline${ }^{207} \mathrm{Bi}$ & $1.7 \times 10^{10}$ & $1.8 \times 10^{-2}$ & $1.1 \times 10^{-2}$ & $1.0 \times 10^{-5}$ & $<0.01$ \\
\hline${ }^{125} \mathrm{Sb}$ & $1.7 \times 10^{11}$ & $2.5 \times 10^{-1}$ & $1.1 \times 10^{-2}$ & $1.0 \times 10^{-5}$ & $<0.01$ \\
\hline${ }^{155} \mathrm{Eu}$ & $9.6 \times 10^{10}$ & $1.4 \times 10^{-1}$ & $1.1 \times 10^{-2}$ & $3.3 \times 10^{-3}$ & $<0.01$ \\
\hline${ }^{129} \mathrm{I}$ & $3.9 \times 10^{8}$ & $4.4 \times 10^{-8}$ & $1.1 \times 10^{-2}$ & $2.0 \times 10^{-7}$ & $<0.01$ \\
\hline${ }^{3} \mathrm{H}$ & $5.2 \times 10^{13}$ & $5.6 \times 10^{-2}$ & $1.1 \times 10^{-2}$ & $1.0 \times 10^{-8}$ & $<0.01$ \\
\hline${ }^{205} \mathrm{~Pb}$ & $1.9 \times 10^{8}$ & $5.0 \times 10^{-8}$ & $1.1 \times 10^{-2}$ & $1.7 \times 10^{-3}$ & $<0.01$ \\
\hline
\end{tabular}

The screening calculations will be based on an elevated ingestion rate of $200 \mathrm{~kg} / \mathrm{yr}$ of fish and marine mammals. For ${ }^{60} \mathrm{Co}$ and ${ }^{90} \mathrm{Sr}$ the RAIG will use BCFs of 1 and $0.002 \mathrm{~m}^{3} / \mathrm{kg}$, and doseconversion factors of $3.4 \times 10^{-9}$ and $2.8 \times 10^{-8} \mathrm{~Sv} / \mathrm{Bq}$, respectively (Table 2-11).

\section{Sea of Japan and East Coast of Kamchatka}

The inventories of ${ }^{60} \mathrm{Co}$ in the reactor-related components dumped in Areas 8, 9, and 10 are 2,500, 160 , and $870 \mathrm{GBq}$, respectively. If these amounts of radioactivity were mixed into $3.6 \times 10^{15} \mathrm{~m}^{3}$ of water, the resulting concentrations would be $6.9 \times 10^{-4}, 4.4 \times 10^{-5}$, and $2.4 \times 10^{-4} \mathrm{~Bq} / \mathrm{m}^{3}$. The associated annual dose estimates are below $5 \times 10^{-7} \mathrm{mSv} / \mathrm{yr}$, which is more than a million times lower than the annual background dose of approximately $2 \mathrm{mSv}$ that most of the world's population receives annually from various sources (UNSCEAR, 1988). The presence of these wastes is unlikely to represent a radiological hazard even to the local seas in which they are located because releases will take place slowly over time as corrosion products are emitted to the ocean/sediment system at the waste sites. Mount et al. (1996) estimated that the total release of activation products from the submarine-reactor core plate in Area 8 starts below $0.01 \mathrm{GBq} / \mathrm{yr}$ and over 1,000 
years, falls to $100 \mathrm{~Bq} / \mathrm{yr}$. The predicted release rates for the two reactors and the reactor lid in Area 10 were added together, taking into account their different dates of dumping. The total release rate begins at about $1 \mathrm{GBq} / \mathrm{yr}$, dropping off to a level less than $0.1 \mathrm{GBq} / \mathrm{yr}$, extending past the year 4000 .

\section{Sea of Okhotsk: ${ }^{90} \mathrm{Sr}$ Radioisotope Thermoelectric Generator}

From a screening standpoint, the ${ }^{90} \mathrm{Sr}$-powered RTG represents a significant nuclear source, as the dilution of $11,000 \mathrm{TBq}$ of ${ }^{90} \mathrm{Sr}$ in $3.6 \times 10^{15} \mathrm{~m}^{3}$ of water would result in a concentration of $3 \mathrm{~Bq} / \mathrm{m}^{3}$, which is above background levels in the Pacific Ocean. The associated dose rate, however, is far below background levels at an estimated $3.4 \times 10^{-5} \mathrm{mSv} / \mathrm{yr}$. While instantaneous release of the ${ }^{90} \mathrm{Sr}$ source at the time of loss is the most conservative as to environmental impact, considering the reported hermetically sealed solid construction of the RTG (Danilyan and Vysotsky, 1995) and the robust construction expected, it is not unreasonable to assume that the steel construction will survive long enough for radioactive decay to make the source strength of much less consequence to the environment when it finally begins to be released. Furthermore, once release does occur, the portion of the ${ }^{90} \mathrm{Sr}$ released that would end up in the Bering Sea would depend on the actual location of the RTG in Sea of Okhotsk and movement of currents from that location to the Pacific Ocean and then the Bering Sea. Given that the dose estimate for instantaneous release is very low and that transport from the Sea of Okhotsk to the Bering Sea would further reduce the levels of ${ }^{90} \mathrm{Sr}$ in seawater, the RAIG concludes that the RTG constitutes no significant threat to the Arctic.

\subsection{Release Scenarios}

Our review of the available information on FSU nuclear wastes dumped in the Arctic and Pacific Oceans and stored at inland locations adjacent to the $\mathrm{Ob}$ and Yenisey Rivers in the West Siberian Basin indicates that the risk assessment should focus on radionuclide releases from naval reactors disposed in the Kara Sea and from the waste storage ponds and reservoirs at the inland sites. As a means of addressing the uncertainties inherent in deriving estimates of the releases from such sources, the RAIG presents both acute and chronic release scenarios. Acute release scenarios are meant to represent catastrophic or upper-bound releases of radionuclides to the Kara Sea or rivers, whereas the chronic release scenarios represent the slow discharge of nuclides to seawater via the corrosion/dissolution of fuels or leakage from wastewater reservoirs to surface waters of the $\mathrm{Ob} /$ Yenisey river systems. Thus, the acute scenarios are assumed to be less likely than the chronic cases, but have the potential for substantially higher releases of radionuclides.

\subsubsection{Kara Sea}

The acute or upper-bound release case for the Kara Sca sources was defined as the instantaneous discharge of the inventories of ${ }^{90} \mathrm{Sr},{ }^{137} \mathrm{Cs},{ }^{239} \mathrm{Pu}$, and ${ }^{241} \mathrm{Am}$ (i.e., $0.95,1.0,0.006$, and $0.008 \mathrm{PBq}$ ) to seawater. This release scenario is unlikcly to occur because it is difficult to postulate the mechanism(s) by which the nuclides of concern could be abruptly transferred to seawater. Nevertheless, the hypothesized release does constitute an upper-bound case and the available inventories will decline with time because of radioactive decay. After 100 years, for example, the inventories of ${ }^{90} \mathrm{Sr}$ and ${ }^{137} \mathrm{Cs}$ will be about a factor of 10 lower than the present inventories. The decay 
rates for ${ }^{239} \mathrm{Pu}$ and ${ }^{241} \mathrm{Am}$ are much slower, and consequently the inventories of those nuclides will remain elevated for centuries.

The more realistic release mechanism for the fission products and actinides in spent reactor fuels is the corrosion of fuel elements by seawater. Corrosion-based releases of the nuclides have been estimated by the IASAP STWG (IAEA, 1997). The time-varying release rates are calculated as the product of the activity of a given radionuclide present at time $t$ in SNF and the ratio of the volume of SNF corroded at time $t$ to the initial volume of the SNF. The effective corrosion rate is estimated by adjusting a base corrosion rate to account for the degree of SNF containment and the use of Furfurol (F) as a barrier material. Corroded material is assumed to be soluble and available for subsequent transport. This is clearly a conservative case, as corroded material may largely remain as insoluble debris at the various waste locations (IAEA, 1997).

The STWG prepared alternative scenarios to describe future radionuclide releases from the reactors dumped in the Kara Sea. Most relevant for the risk assessment is the "best estimate" case, in which radionuclides are gradually released to seawater as the SNF corrodes. Other scenarios included abrupt, catastrophic releases associated with external events or glacial scouring of the fjords after 1,000 years. These types of scenarios are essentially the same as the acute release described above, except there is a prolonged period that allows the inventories of some radionuclides to decline substantially. The time-varying releases of ${ }^{90} \mathrm{Sr},{ }^{137} \mathrm{Cs},{ }^{239} \mathrm{Pu}$, and ${ }^{241} \mathrm{Am}$ are shown in Figure 2-7. The initial peak represents the early entry of seawater to unprotected $R C s$, while a secondary peak occurs in the year 2300 when containers holding damaged SNF are broached and fission products and actinides are then released to seawater.

\subsubsection{West Siberian Basin}

Releases of radioactive effluents to the $\mathrm{Ob}$ and Yenisey River systems from the nuclear facilities at Mayak (Techa/Ob Rivers), Tomsk (Tom/Ob Rivers), and Krasnoyarsk (Yenisey River) could occur as accidental discharges of LRWs from storage reservoirs or as chronic releases in the form of waste water seeping through earthen retaining dams or contaminated groundwater that discharges to the river. To characterize the potential release from these source terms, the RAIG reviews pertinent information on the radionuclide inventories associated with waste-storage ponds and develops preliminary estimates of effluent discharges for both accidental and chronic release modes.

\section{Accidental or Acute Release Scenarios}

\section{Mayak: Releases from Waste-Water Reservoirs}

RWs at the Mayak site (Figure 2-6) are stored in a combination of lakes and man-made reservoirs that are linked in series by canals or separated by earthfill dams over a linear distance of $30 \mathrm{~km}$. Four dams are associated with Reservoirs 3,4, 10, and 11. In the past, discharge from the final reservoir in the series (Reservoir 11) was directly into the Techa River. The height of the earthfill dam on this reservoir has been raised by $2 \mathrm{~m}$ over time to prevent discharge of contaminated water into the Techa River (Bradley and Jenquin, 1995) and canals were built in 1963 (left-bank canal) and 1972 (right-bank canal) to allow the Techa River flow to bypass the series of reservoirs named above. The dam on Reservoir 11 has leaked in the past, and continues to leak now, resulting in the continued contamination of the lecha River (Bradley and Jenquin, 1995). 
An extreme-event release would occur if there were a common initiating event such as an earthquake or flood that caused the failure of the earthen dams associated with Reservoirs 3, 4, 10, and 11. Reservoir 17 also has a retaining dam; however, it is not in the main chain of reservoirs, as shown in Figure 2-7. Another mechanism of dam failure is the wetting-induced collapse of compact soil. Collapse (once wetting starts to occur) would be essentially instantaneous (e.g., 4 hours or less) (Lawton et al., 1992). This failure mechanism would presumably be site-specific; however, the wetting-induced collapse of the earthen dam at Reservoir 10 could lead to the failure of Reservoir 11, the next reservoir in the chain, which would then discharge to the Techa River. Depending on the extent of the dam failure(s) (i.e., a small section of a dam versus a major col-

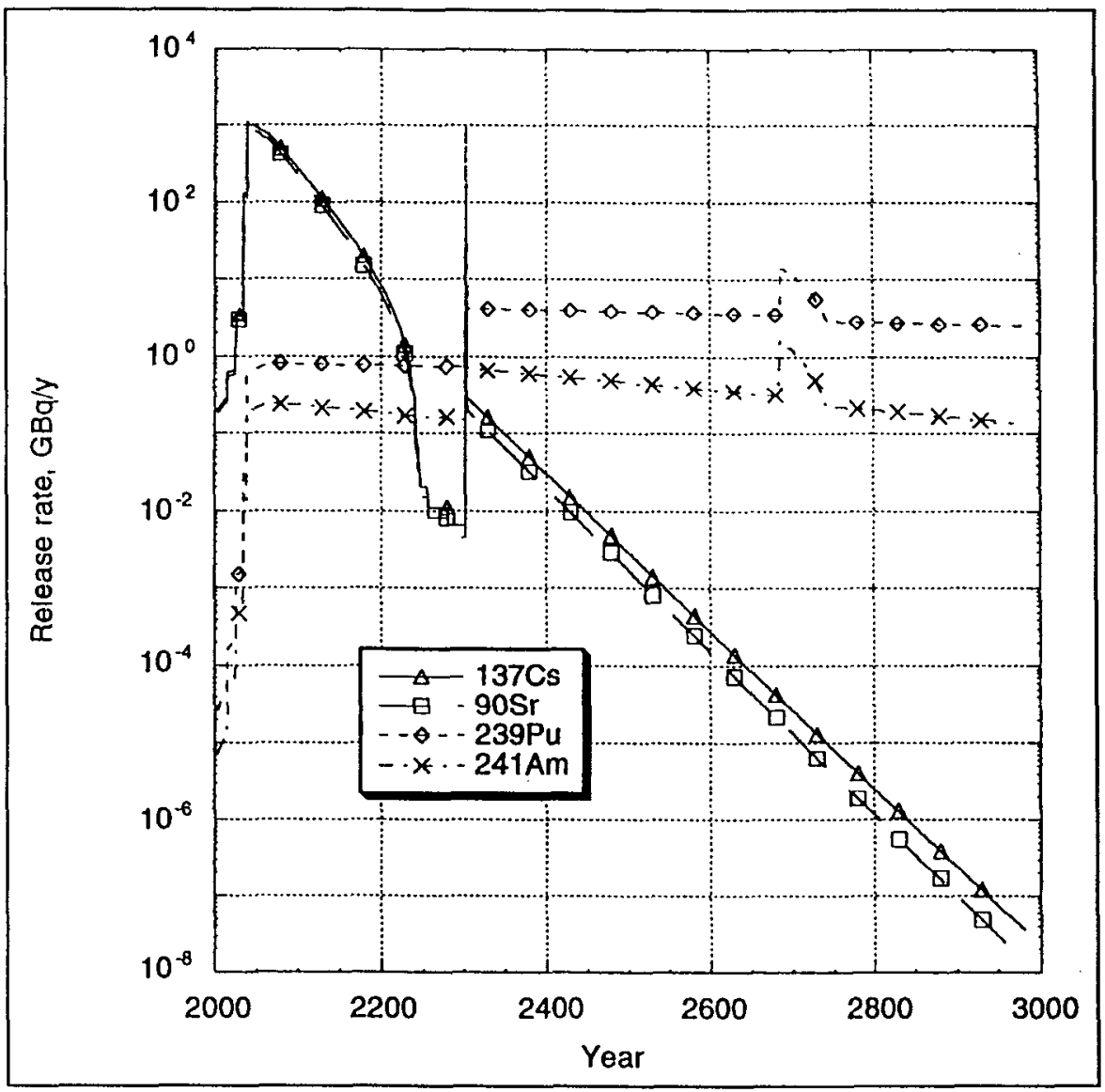

Figure 2-7. Time-varying release rates of radionuclides from naval reactors dumped in the Kara Sea (from IAEA, 1997).

lapse), it is conceivable that remedial actions could be taken to limit the total amount of LRWs discharged as well as the rate of discharge.

Without detailed analyses of the probabilities of different earthquake intensities of this area of Russia, the likelihood of wetting-induced collapse, the magnitude and frequency of floods, and the structural response of the dams to such events, it is not possible to determine which failure modes are most plausible for the Mayak reservoirs. Nevertheless, it appears that Reservoirs 10 and 11 are the most vulnerable based on their collocation and the possibility that the failure of one reservoir could lead to the failure of the other. The radioactive liquid wastes in these reservoirs that could be released to the Techa River contain $1,400 \mathrm{TBq}$ of ${ }^{90} \mathrm{Sr}$ and $24 \mathrm{TBq}$ of ${ }^{137} \mathrm{Cs}$ (see 
Table 2-10). Based on previous problems and remedial actions at Mayak, discussed in Bradley and Jenquin (1995), the RAIG expects that efforts to contain a major release would be made at Mayak by the addition or reinforcement of earthfill dams, or similar efforts.

To account for the fact the dam-reservoir system is under active institutional control and that remedial actions would undoubtedly be instituted to deal with a breached dam, the RAIG assumes that the release of radioactive liquids from Reservoirs 10 and 11 would occur continuously over a 1-year period. This type of release would produce a discharge that is comparable in magnitude to the releases occurring during the period 1949 to 1951, when an estimated 1,000 TBq of ${ }^{90} \mathrm{Sr}$ and ${ }^{137} \mathrm{Cs}$ in LRWs were discharged directly to the Techa River from the Mayak facility (each nuclide contributed about half of the total activity; Trapeznikov et al., 1994). However, the release scenario described here would be dominated by ${ }^{90} \mathrm{Sr}$ and would occur over a shorter period of time. The constant discharge rates for ${ }^{90} \mathrm{Sr}$ and ${ }^{137} \mathrm{Cs}$ would be 4 and $0.07 \mathrm{TBq} / \mathrm{d}$, respectively, for one year (based on $1,400 \mathrm{TBq}$ and $24 \mathrm{TBq}$ of those radionuclides in the LRWs stored in the two reservoirs). Because of the preliminary nature of this scenario, it should be viewed primarily as a screening-level case that constitutes a plausible release event for use in the risk assessment.

\section{Tomsk and Krasnoyarsk: Releases from Waste-Water Reservoirs}

At Tomsk, the potential for an accidental release is not as clear. There are apparently eight reservoirs at the site: three natural ponds, three man-made ponds, and two sludge pits (personal communication, D. Bradley, Pacific Northwest National Laboratory, August 19, 1996). Collectively, these reservoirs contain one million TBq $\left(10^{18} \mathrm{~Bq}\right)$ of LRW. They are located $<5 \mathrm{~km}$ from the Tom River and may be connected to it by a small creek or river. Bradley and Jenquin (1995) also mentioned a "special sewer" for the disposal of plutonium machining waste. The low-lying, flat nature of the local terrain near the Tomsk reservoirs along with the prospect for backwater phenomena (the spring freshet from the Irtysh River entering the Ob River at Belogorye prevents the release of the spring freshet on the upper $\mathrm{Ob}$ and Tomsk Rivers) increases the possibility that flooding could cause discharges of LRWs from the reservoirs. Unfortunately, data on the actual radionuclide composition of the wastes are not available and the characteristics of the ponds/ reservoirs, dams, and canals are unknown, and therefore it is not possible to develop an accidental release scenario for this facility. As a default, the RAIG will use the Mayak release described above to represent an accidental discharge of LRW from either facility into the Ob River system and subsequently the Kara Sea.

The Krasnoyarsk facility also has surface reservoirs for the storage of LRWs, but according to Bradley and Jenquin (1995), the total inventory of radionuclides is much lower than for Mayak and Tomsk (i.e., less than $2,000 \mathrm{TBq}$ ) as well as the total reservoir volume (under $300,000 \mathrm{~m}^{3}$ ). 'The principal reason for this is that the subsurface injection of LRWs has been the primary method of disposal-not surface storage in reservoirs. Historically, the primary radioactive effluents from Krasnoyarsk that have contaminated the Yenisey River have been discharges from the once-through cooling systems of its production reactors.

Although the limited information available on Krasnoyarsk prevents the development of a plausible release scenario of LRWs to the Yenisey River, the reference Mayak event is certainly larger than any release that could occur at Krasnoyarsk. 


\section{Remobilization of Asanov Marsh ${ }^{90}$ Sr Inventory}

Trapeznikov et al. (1994) reported that about $10,000 \mathrm{TBq}$ of ${ }^{90} \mathrm{Sr}$ was released as a result of Mayak operations between 1949 and 1951, about $80 \%$ of this material is estimated to remain in the Mayak Reservoir system; $15 \%$ was discharged to the Ob River system, and the remaining $5 \%$ is in the sediments and flood plain of the Techa River. Decay correcting this amount to 1994 leaves about $200 \mathrm{TBq}$ of the original ${ }^{90} \mathrm{Sr}$ inventory. The bulk of this inventory is thought to remain in the Asanov Marsh. Remobilization of this inventory requires a scenario in which the marsh soil and flora are dewatered and subsequent flood events wash organic matter and loose soil into the Techa River. Because this release scenario would not result in the discharge of as much ${ }^{90} \mathrm{Sr}$ as the hypothesized release from the Mayak Reservoirs 10 and 11, the RAIG will use the Mayak release to represent an acute discharge of radioactive effluents to the Kara Sea from inland sources. How ever, the RAIG cannot, at this point, determine which release scenario is more likely to occur.

\section{Chronic-Release Scenarios}

The $\mathrm{Ob}$ and Yenisey rivers have discharged ${ }^{\text {In }} \mathrm{Sr}$ and other radionuclides to the Kara Sea since the early 1950s. The primary sources of the radionuclide discharges have been the runoff of nuclides deposited onto watersheds in the form of nuclear fallout and the discharge of LRWs to rivers. Unless there are major new releases, the discharges should gradually decline as the inventories of the various radionuclides undergo radioactive decay. To establish the basis for a chronic-release scenario of ${ }^{90} \mathrm{Sr}$ into the Kara Sea from the two rivers, the RAIG reviews data on the magnitude of historic discharges and assesses the potential magnitude of chronic releascs produced by discharges of contaminated groundwater and leakage from earthen dams. The RAIG then presents the relcase rates used to represent these scenarios in the risk assessment.

\section{Historical ${ }^{90} \mathrm{Sr}$ Fluxes from the $\mathrm{Ob}$ and Yenisey Rivers}

The observed flux of ${ }^{90} \mathrm{Sr}$ at Salekhard (near the point where the Ob River discharges into the Kara Sea estuary) largely is due to washoff from the watershed of atmospheric fallout. The historical ${ }^{90} \mathrm{Sr}$ flux from the $\mathrm{Ob}$ River since 1970 has been about 10 to $40 \mathrm{TBq} / \mathrm{yr}$, based on an average $\mathrm{Ob}$ River flow rate of $12,680 \mathrm{~m}^{3} / \mathrm{s}$ (data from Bobkin and Bobrovitskaya, 1995) and ${ }^{90} \mathrm{Sr}$ concentrations in river water of $25-100 \mathrm{~Bq} / \mathrm{m}^{3}$ (Chumichev, 1995). In contrast, Vakulovsky et al. (1995) estimate that the flux of ${ }^{90} \mathrm{Sr}$ from the Yenisey River averaged about $1.5 \mathrm{TBq} / \mathrm{yr}$ during the years 1985 to 1991.

\section{Near-Surface Groundwater Plumes from Reservoir Leachate}

Seepage of leachate from the surface reservoirs containing LRWs has contaminated groundwater beneath the storage reservoirs and lakes at Mayak. Subsequent discharge of the contaminated groundwater to the Techa River represents a potential source of river contamination. Similar groundwater contamination undoubtedly occurs at Tomsk and Krasnoyarsk, but less is known about its extent. The magnitude of the groundwater transport mechanism depends on a number of factors, including the hydrologic gradient beneath the sites, the direction of groundwater flow, the extent of radionuclide adsorption to aquifer materials, etc. In the most simple analysis, a contaminant plume beneath a reservoir is estimated to be advected with the steady-state flow rate of the groundwater. The flux of ${ }^{90} \mathrm{Sr}$ in groundwater can therefore be calculated as the product of the uniform concentration of ${ }^{90} \mathrm{Sr}$ in groundwater (assumed to be equal to its concentration 
in a reservoir) and the volumetric discharge of groundwater. The groundwater flow rate is equal to the velocity of groundwater and the cross section of the plume (based on a plume thickness of $2 \mathrm{~m}$ and the width of a reservoir).

As an example calculation, Bradley and Jenquin (1995) reported that the plume below Lake Karachai has migrated $2.5 \mathrm{~km}$ in 40 years, and this implies a plume velocity of approximately 60 $\mathrm{m} / \mathrm{yr}$. For Lake Karachai (Reservoir 9 with a ${ }^{90} \mathrm{Sr}$ concentration of $0.063 \mathrm{TBq} / \mathrm{m}^{3}$, an inventory of $25,000 \mathrm{TBq}$, and an area of $0.25 \mathrm{~km}^{2}$ ) the flux is estimated to be $4,400 \mathrm{TBq} / \mathrm{yr}$, and therefore the plume will discharge for nearly six years (i.e., 25,000/4,400). The assumption that this groundwater velocity is representative of all contaminant plumes is unlikely to be valid across the various reservoir/aquifer systems; however, it is commensurate with the preliminary nature of this sourceterm analysis. Using the methodology described above, the RAIG has estimated the non-decaycorrected flux rate of ${ }^{90} \mathrm{Sr}$ from each of the Mayak Reservoirs to groundwater and then to surface water. Table 2-10 presents the estimated fluxes for near-surface reservoir leachate entering the groundwater and then discharging to the Techa River. The release periods are calculated by dividing the inventory by the flux rate. The estimated fluxes vary considerably in their magnitude and duration. Because the fluxes estimated for Lake Karachai and Reservoir 17 are relatively short in duration, but large in magnitude, they can be represented by the surface-water release described earlier consisting of a 1,400 TBq discharge of ${ }^{90} \mathrm{Sr}$ from Reservoirs 10 and 11 that lasts continuously for one year. Given the various simplifying assumptions used to estimate the groundwater fluxes of ${ }^{90} \mathrm{Sr}$ from Lake Karachai and Reservoir 17, the RAIG believes that those predicted fluxes are unlikely to exceed the surrogate surface-water release scenario-especially if remedial actions were instituted to limit the groundwater discharges.

The longer-term discharges to surface water can be simulated as the product of a base discharge rate and a decaying source term, or

$\mathrm{F}(t)=\mathrm{F}_{\mathrm{b}} \mathrm{e}^{-\lambda_{\mathrm{d}}}$,

where $F(t)$ is the flux to the Kara Sea (in Bq/yr) at time $t$ (in years), $F_{b}$ is the base flux of ${ }^{90} \mathrm{Sr}$ at the beginning of the assessment period, and $\lambda_{d}$ is the rate constant for the radioactive decay of ${ }^{90} \mathrm{Sr}$ (i.e., $0.024 / \mathrm{yr}$ ). This formulation can be used to represent the long-term discharge of contaminated ground water as well as seepage from the earthen dams at the various reservoirs. Based on the magnitude of the historic discharges of ${ }^{90} \mathrm{Sr}$ and the estimated discharges from groundwater shown in Table 2-13, the RAIG has selected a base flux of $40 \mathrm{TBq} / \mathrm{yr}$ to reflect the chronic discharges of ${ }^{90} \mathrm{Sr}$ to the $\mathrm{Ob}$ and Yenisey rivers in the form of groundwater discharges, reservoir leakage, and watershed runoff. This flux is on the upper end of the historic discharges from the Ob River since 1970 and encompasses the release rates presented in Table 2-13 for chronic groundwater discharges (i.e., up to $8 \mathrm{TBq} / \mathrm{yr}$ ) plus a significant amount of dam seepage for both Mayak and Tomsk. 
Table 2-13. Estimates of the maximum fluxes of ${ }^{90} \mathrm{Sr}$ to the surface water from the discharge of contaminated groundwater.

\begin{tabular}{cll}
\hline Reservoir & Computed Flux Rate $(\mathrm{TBq} / \mathrm{yr})$ & Release Duration $(\mathrm{y})$ \\
\hline 2 & 0.25 & 140 \\
3 & 6.7 & 7 \\
4 & 1.0 & 26 \\
6 & 0.004 & 65 \\
9 & 4,400 & 6 \\
10 & 7.9 & 130 \\
11 & 1.8 & 230 \\
17 & 15 & 5 \\
\hline
\end{tabular}

\subsection{SUMMARY}

- Operation of the Sellafield nuclear reprocessing facility in Great Britain has resulted in the discharge of approximately $41,000 \mathrm{TBq}$ of ${ }^{137} \mathrm{Cs}$ to the Irish Sea through 1992 . Of this amount, an estimated $9,000 \mathrm{TBq}$ has entered the Arctic Ocean. In contrast, only about $20 \mathrm{TBq}$ of the 590

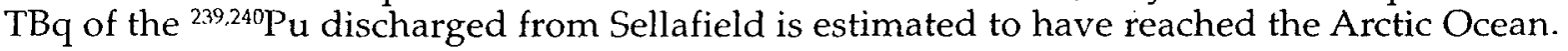

- Source-term analyses of the marine reactors dumped in the Kara Sea indicate that about 1,000 $\mathrm{TBq}$ of ${ }^{137} \mathrm{Cs}$ and $6 \mathrm{TBq}$ of ${ }^{239,240} \mathrm{Pu}$ remain in the SNF. Unlike the Sellafield-derived nuclides that are already present in the water column, the reactor-based nuclides constitute a potential threat to the Arctic Ocean because future releases will depend on the rate of corrosion/dissolution processes. In any event, the historic releases from Sellafield are a more significant source of ${ }^{137} \mathrm{Cs}$ and ${ }^{239,240} \mathrm{Pu}$.

- Screening analyses of the radionuclides present in the Kara Sea, the Northwest Pacific Ocean, and LRWs in ponds and reservoirs in the West Siberian Basin indicate that the principal radionuclides of potential concern are ${ }^{90} \mathrm{Sr},{ }^{137} \mathrm{Cs},{ }^{239} \mathrm{Pu}$, and ${ }^{241} \mathrm{Am}$. In addition, the most credible sources in terms of future impacts to Alaskan waters are the Kara Sea wastes and the LRWs stored at inland locations in Russia.

- Radionuclides released from the Kara Sea and West Siberian Basin were characterized by using two different types of scenarios, one to represent acute or accidental releases and the other to represent chronic releases. For the inland sources, the acute scenario consists of the discharge of $1,400 \mathrm{TBq}$ of ${ }^{90} \mathrm{Sr}$ and $24 \mathrm{TBq}$ of ${ }^{137} \mathrm{Cs}$ from Reservoirs 10 and 11 at Mayak to the $\mathrm{Ob}$ River system. The chronic scenario consists of a base discharge of $40 \mathrm{TBq} / \mathrm{yr}$ of ${ }^{90} \mathrm{Sr}$ from reservoir leakage that declines with time as a function of the radioactive decay of ${ }^{90} \mathrm{Sr}$. 


\section{Transport of Radionuclides in the Arctic Seas}

D. Layton ${ }^{\mathrm{a}}$, P. Vaughn ${ }^{\mathrm{b}}$, L. Yarrington ${ }^{\mathrm{b}}$, R. Maxwella, R. Prellerc, J. Bean ${ }^{\mathrm{b}}$, J. Carrolld,

M. Fuhrmanne, I. Rigorf, and W. Tuckerg

aLawrence Livermore National Laboratory, Livermore, CA

bSandia National Laboratories, Albuquerque, NM

'Naval Research Laboratory, Stennis Space Center, MS

dInternational Atomic Energy Agency, Marine Environment Laboratory, MONACO

eBrookhaven National Laboratory, Upton, NY

fPolar Science Center, University of Washington, Seattle, WA

gU.S. Army Cold Regions Research and Engineering Laboratory, Hanover, NH

Three sets of factors control the spatial and temporal changes in the concentration of a radio-
nuclide released into the Arctic Ocean. The first set involves the nature and magnitude of
the releases from various sources; the second set concerns the physical, chemical, and bio-
logical properties of ocean waters transporting the radionuclides; and the final set involves ra-
dionuclide-specific factors, such as radioactive decay and sediment-water partitioning. Section 2
addresses source-term-related factors to estimate potential releases of radionuclides from dump
sites in the Northwest Pacific Ocean and the Kara Sea as well as from riverine sources. This
section presents a methodology for predicting concentrations of radionuclides in Arctic waters
adjacent to Alaska. The methodology uses radionuclide source terms as inputs to models that
simulate the movement of radionuclides in Arctic waters. In addition to actual field measure-
ments, subsequent sections will then use the results of the transport modeling to assess the po-
tential risks to Alaskan populations and aquatic ecosystems. 


\subsection{Selection Criteria for Radionuclide Transport Models}

Key considerations in selecting and implementing models to simulate the transport of radionuclides released into the Arctic Ocean are the spatial and temporal scales required to assess the potential health and ecological impacts of the releases. Basically three spatial scales can be addressed: global, regional, and local. This study is a regional-scale analysis that deals with radionuclide transport in the Arctic Ocean and the potential risks to Alaskan populations from dietary exposures to seafood. In contrast, a global-scale assessment of radionuclide releases is valuable in determining the magnitude of population exposures to radionuclides at low levels in seafood worldwide. A local-scale analysis would focus on a limited geographic region such as the Kara Sea. From a temporal perspective the model also must be able to trace the movement of nuclides in the Arctic Ocean for hundreds of years because of the slow leaching of radionuclides from submerged reactors. Such a model also must be able to complete simulations of radionuclide release scenarios or conduct sensitivity analyses in a reasonable amount of time.

Given these criteria, the RAIG used a compartmental model (CM) for the risk assessment. A compartmental model represents an ocean region as a series of linked compartments or boxes that encompass the entire volume of the region being assessed. Each compartment can exchange water with all compartments adjacent to it. Volumes of water on the order $10^{13} \mathrm{~m}^{3}$ and larger (i.e., a single ocean compartment) are thus characterized by a single temperature, salinity, radionuclide concentration, sediment loading, sedimentation rate, etc. This extreme physical simplification is intentional to assure rapid, low-cost, easily run simulations suitable for sensitivity or other repetitive studies carried out by the RAIG.

Compartmental models have been used for many years to assess the potential consequences of radionuclides releases to ocean waters. For example, Clark and Webb (1981) used a model consisting of 17 compartments to assess radionuclide releases to northern European waters. Their basic model formulation and transport equations have been adopted in other studies of radionuclide releases to the marine environment (e.g., Evans, 1985; Hallstadius et al., 1987; Nielsen et al., 1995). Nielsen et al. (1995) developed a comprehensive model for the Northeast Atlantic coastal waters to simulate discharges of radionuclides from the nuclear reprocessing plants at Sellafield, UK, and La Hague, France. Alternative modeling approaches such as general circulation models, turbulent boundary layer models, regional eddy-resolving models, or coastal process models have extensive computational requirements and, when applied to a risk assessment on the scale of the Arctic Ocean, computational requirements become prohibitive.

\subsection{Simulating Radionuclide Transport in the Arctic Ocean}

The basic compartmental structure for the model represents a vertical column that extends from a sediment layer to the water surface (Figure 3-1). The water portion of the column is represented by either a two-box configuration, where a surface compartment is underlain by a lower compartment, or by a single box for shallow areas such as shelf regions. A well-mixed sediment layer resides at the bottom of each water column. Water exchanges between adjoining compartments occur both in the vertical and horizontal domains for the two-box vertical configuration, but in the single-box case only horizontal water exchanges occur. 


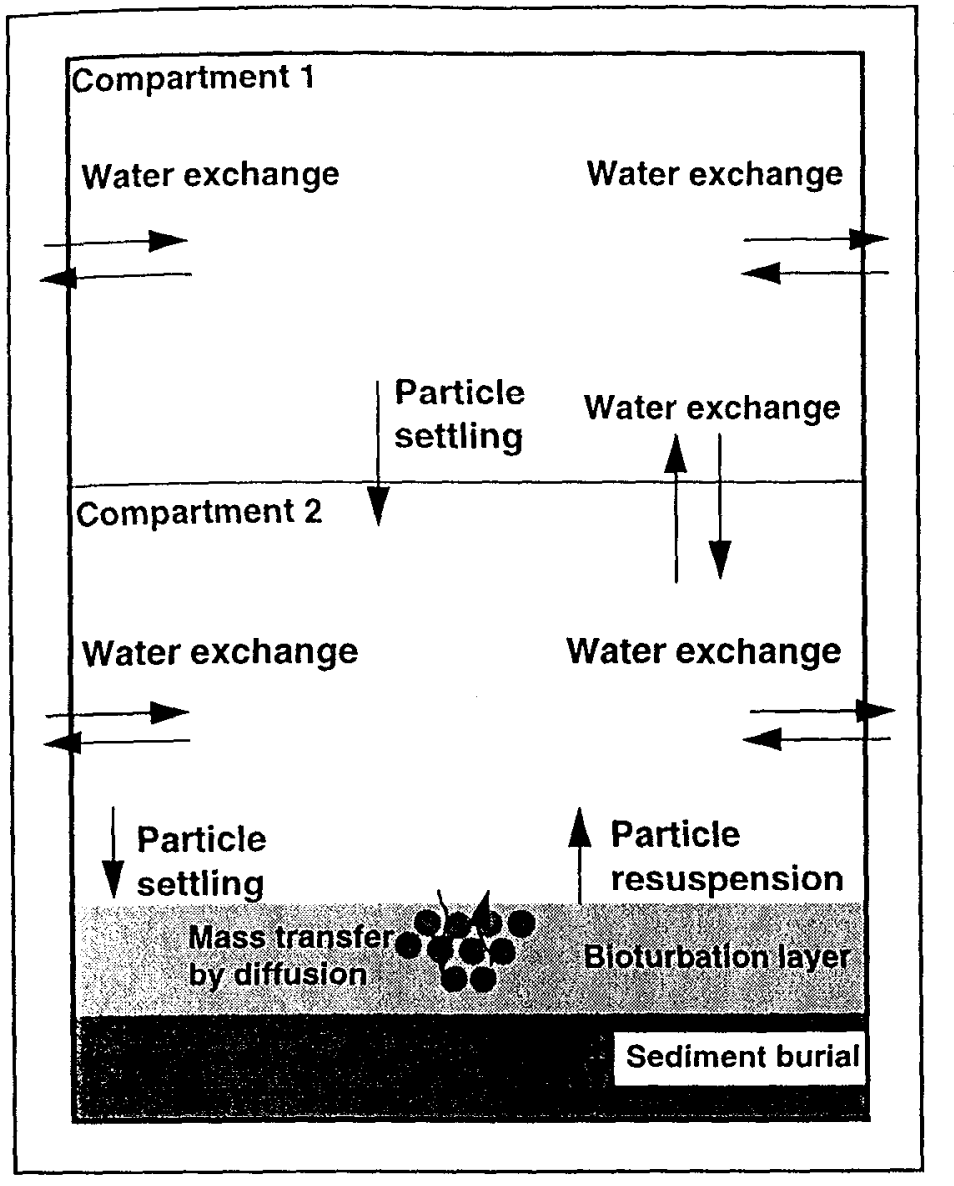

Figure 3-1. Basic compartmental structure for simulating the advective transport of radionuclides in water between two stacked water compartments as well as adjacent water compartments.

Radionuclide exchanges also occur between a bottom water compartment and a sediment layer via particle settling and resuspension and pore-water diffusion.

Transport of radionuclides in the water compartments is governed by water flows between compartments as well as the vertical deposition of particle-bound nuclides to sediment. A sediment compartment is used to represent the accumulation of radionuclides in an active sediment layer as a result of resuspension, bioturbation, pore-water diffusion, and burial. Losses of radionuclides within each compartment also occur via radioactive decay. The relative importance of the water- and sediment-based transport processes for a given radionuclide is a function of its physicochemical properties as well as the characteristics of the marine environment that serves as the transport medium.

The following subsection presents an overview of the mathematical equations used to simulate radionuclide transport mechanisms and to predict radionuclide concentrations within individual model compartments. To provide insight on which of the transport mechanisms are most important, follow-on subsections provide explanations of the potential significance of the sediment/ water distributions of the nuclides, the role of sediment deposition/resuspension, and finally, the transport of sediment-bound nuclides by near-shore ice. 


\subsubsection{Mathematical Formalism for the Compartmental Model}

The governing equation for the total activity of a radionuclide in the $i$ th compartment is given by

$\frac{d A_{i}}{d t}=\sum_{j=1}^{n} k_{j i} A_{j}-\sum_{j=1}^{n} k_{i j} A_{i}-\lambda_{d} A_{i}+Q_{i}(t)$

where $A_{i}$ is the total activity $(\mathrm{Bq})$ for compartment $i$ in both dissolved and particulate phases. The terms $k_{i j}$ (rate constant for radionuclide transfers from compartment $i$ to $j$ ) and $k_{j i}$ (rate constant for radionuclide transfers from compartment $j$ to $i$ ) represent the rate constants (in $1 / y r$ ) for intercompartment exchanges for the $n$ compartments in the system. Additional terms address radioactive decay $\left(\lambda_{d}\right.$, in $\left.1 / y r\right)$ and time-varying sources $\left(Q_{i}\right)$ within individual compartments $(\mathrm{Bq} / \mathrm{yr}$ ). These equations simply state, in mathematical terms, that the radioactivity (or mass) of radionuclide entering a given compartment minus the radioactivity (or mass) leaving a compartment must equal the radioactivity (or mass) of the radionuclide that accumulates in the compartment. The transfer rate constant for the volumetric exchange between adjoining horizontal compartments $i$ and $j$ is calculated from

$k_{i j}=\frac{F_{i j}}{V_{i}}$,

where $F_{i j}$ is the volumetric flow rate of water from compartment $i$ to compartment $j\left(\mathrm{~m}^{3} / \mathrm{yr}\right.$ ) and $V_{i}$ is the volume $\left(\mathrm{m}^{3}\right)$ of the $i$ th compartment. The rate constant representing both water exchange and the settling of particle-bound radionuclides from the top water compartment to the lower water compartment in a two-layer water column is estimated from

$k_{i j}=\frac{F_{i j}}{V_{i}}+\frac{A_{s} S_{v}\left(1-\phi_{d w}\right)}{V_{i}}$,

or alternatively,

$k_{i j}=\frac{F_{i j}}{V_{i}}+\frac{\mathrm{K}_{\mathrm{d}} \mathrm{S}_{\mathrm{V}} \mathrm{S}_{\mathrm{L}}}{\mathrm{h}\left(1+\mathrm{K}_{\mathrm{d}} \mathrm{S}_{\mathrm{L}}\right)^{\prime}}$,

where

$\phi_{d z l}=\frac{1}{\left(1+\mathrm{K}_{\mathrm{d}} \mathrm{S}_{\mathrm{L}}\right)}$ 
and

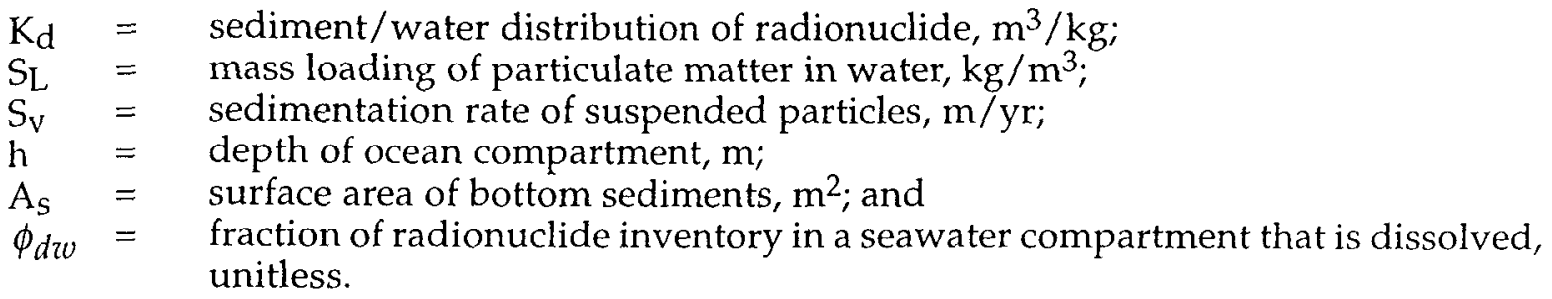

Exchanges of a radionuclide between a benthic water compartment and a sediment compartment are simulated using rate constants that represent the movement of radionuclides from water to sediment compartments and from sediment to the overlying water compartment. The primary transport mechanisms for water-to-sediment transfer of a radionuclide are the deposition of particle-bound nuclides and the diffusion of a dissolved radionuclide from seawater to sediment pore water under a concentration gradient. For water-to-sediment transfers, the rate constants are calculated (after Gobas et al., 1995) as

$k_{i j}=\frac{A_{s} T_{m} \phi_{d s}}{V_{i}}+\frac{A_{S} S_{v}\left(1-\phi_{d s}\right)}{V_{i}}$,

where

$\phi_{d s}=\frac{1}{\left(1+\mathrm{K}_{\mathrm{d}} \rho_{s}\left(1-\theta_{s}\right)\right)^{\prime}}$

and

$\phi_{d s}=$ fraction of radionuclide inventory in the sediment compartment that is dissolved,

$\mathrm{T}_{\mathrm{m}}=$ mass-transfer coefficient for diffusive transfers of a radionuclide

$\theta_{S}$ between pore water in sediment and the water column, $\mathrm{m} / \mathrm{yr}$;

$\theta_{S}=$ porosity of sediment layer, unitless; and

$\rho_{S}=$ density of sediment particles, $\mathrm{kg} / \mathrm{m}^{3}$.

Transfers from sediment to overlying water occur via diffusion of soluble species from pore water to overlying water and by resuspension of sediment. The rate constant for these processes is expressed as

$k_{i j}=\frac{A_{s} T_{m} \phi_{d s}}{V_{i}}+\frac{\frac{R_{s}}{\left(\rho_{s}\left(1-\theta_{s}\right)\right)}\left(1-\phi_{d s}\right)}{V_{i}}$,

where $R_{s}$ is the resuspension rate of sediment, $\mathrm{kg} / \mathrm{yr}$. The resuspension rate can be calculated as the difference between sediment burial and deposition, or 
$R_{\mathrm{S}}=\mathrm{A}_{\mathrm{S}}\left(\mathrm{S}_{\mathrm{v}} \mathrm{S}_{\mathrm{L}}-\mathrm{B}_{\mathrm{r}} \rho_{\mathrm{s}}\left(1-\theta_{\mathrm{S}}\right)\right)$

where $B_{r}$ is the burial rate of sediment, $\mathrm{m} / \mathrm{yr}$.

\subsubsection{Radionuclide Partitioning Between Sediment and Seawater}

Particulate matter, also known as sediment, exists in natural marine systems both suspended in seawater and deposited on the seafloor. In response to physicochemical reactions that occur in seawater, contaminants introduced into a marine system will be partitioned between particles and seawater (Duursma and Carroll, 1996). In most transport models, a simple parameter known as the distribution coefficient $\left(\mathrm{K}_{\mathrm{d}}\right)$ is used to predict the quantities of a contaminant dissolved in seawater and altached to particles (e.g., Eqs. 3-5 and 3-7). The distribution coefficient is defined as

$K_{d}=\frac{C_{s}}{C_{w}}$

and is based on the assumption that the concentrations of a contaminant in water $\left(\mathrm{C}_{\mathrm{w}^{\prime}}\right.$ in $\left.\mathrm{Bq} / \mathrm{m}^{3}\right)$ and particulate matter $\left(\mathrm{C}_{\mathrm{s}^{\prime}}, \mathrm{Bq} / \mathrm{kg}, \mathrm{dw}\right.$ of material $)$ are at steady-state, or equilibrium conditions. As $\mathrm{K}_{d}$ increases, more contaminant is associated with particles and hence contaminant behavior in water becomes more dependent on the fate and transport of particles.

The $K_{d}$ concept assumes that adsorption is the uptake mechanism by which a contaminant attaches to particles. Adsorption is generally considered to be a surface-related chemical attachment process that is completely reversible. Distribution coefficients in marine systems are typically determined through three types of procedures:

(1) Measurements of elemental concentrations in seawater are compared with either a) measurements of elemental concentrations for marine sediments or b) estimates of the exchangeable fraction of the total elemental concentrations for particles not previously exposed to seawater. This approach provides global estimates of $K_{d}$ values, such as is presented in IAEA (1985) for coastal waters.

(2) Local measurements are conducted of specific contaminants associated with marine particles and seawater. While this approach provides site-specific $K_{d}$ values, there is limited certainty that the particles have remained in contact with the seawater from which the contaminant was initially sorbed.

(3) Laboratory and field investigations of contaminant sorption dynamics are performed in batch, isotherm or flow-through column (more appropriate for ground water) experiments. Advantages of the laboratory approach include the ability to determine sorption and desorption kinetics and to evaluate effects of changing environmental conditions. This provides better predictive capabilities, however, issues of maintaining the original properties of the sediment/water matrix and the representativeness of experimental protocols to nature remain concerns in this approach. 
Mechanistically and in the strictest sense the definition of $K_{d}$ (Eq. 3-10) may not be completely appropriate. For example, mechanisms other than adsorption can result in a contaminant moving from seawater to particulate matter, including:

- Precipitation directly from solution;

- Surface-mediated redox reactions and precipitation;

- Ion exchange;

- Isotope exchange;

- Co-precipitation; and

- Organic/metabolic processes.

Furthermore, the state of the art for mechanistically describing adsorption uses models of reactions of species in solution with species on mineral surfaces. These models, known as surfacecomplexation models, provide descriptions (generally by use of a geochemical speciation code) of sorption behavior as a function of $\mathrm{pH}$ and ionic strength. The models do not easily address complex mixtures of minerals and organic matter, as are found in natural seawater systems. As a necessary simplification, transport modelers use the $\mathrm{K}_{\mathrm{d}}$ approach in their models to predict distributions of a contaminant between sediment and seawater.

Data on the sediment-water partitioning of waste-related radionuclides exist for the Kara Sea (Povinec et al., 1996; Fuhrmann et al., 1996; Duursma and Carroll, 1996; Cochran et al., 1996; Carroll et al., 1995). These site-specific $K_{d}$ estimates provided by batch laboratory and ficld $c x-$ periments may be compared to earlier $\mathrm{K}_{d}$ values compiled for coastal waters by the International Atomic Energy Agency (I $\Lambda \mathrm{E} \Lambda, 1985)$ (Table 3-1). Note that the site-specific $\mathrm{K}_{d}$ values are lower than the generic values recommended by the IAEA (1985). This is not surprising because it is well known that particulate matter collected from different coastal marine waters varies in composition (e.g., organic matter content, clay content, grain size, etc.). The site-specific $\mathrm{K}_{d}$ values reflect the unique composition of Kara Sea sediment. 
Table 3-1. Sediment-water distribution coefficients for Am, Cs, Pu, and Sr for Kara Sea sediments.

\begin{tabular}{|c|c|c|c|c|}
\hline \multicolumn{5}{|c|}{ Radionuclide } \\
\hline & $\mathrm{Am}$ & Cs & $\mathrm{Pu}$ & $\mathrm{Sr}$ \\
\hline Source & \multicolumn{4}{|c|}{ Distribution Coefficients $\mathrm{m}^{3} / \mathrm{kg}$ (unitless) $^{a}$} \\
\hline $\begin{array}{l}\text { Povinec et al. } \\
(1996)^{b}\end{array}$ & $10-400\left(0.1-4 \times 10^{5}\right)$ & $0.03-1\left(.3-10 \times 10^{2}\right)$ & $60\left(6 \times 10^{4}\right)$ & $0.01-3\left(.01-3 \times 10^{2}\right)$ \\
\hline $\begin{array}{l}\text { Cochran et } \\
\text { al. (1996) }\end{array}$ & $100\left(1 \times 10^{5}\right)$ & $0.2\left(2 \times 10^{2}\right)$ & & \\
\hline $\begin{array}{l}\text { Fuhrmann et } \\
\text { al. }(1996)^{c}\end{array}$ & - & $0.3\left(.3 \times 10^{2}\right)$ & & $0.004\left(4 \times 10^{0}\right)$ \\
\hline $\begin{array}{l}\text { IAEA } \\
(1985)^{\mathrm{d}}\end{array}$ & $2,000\left(2 \times 10^{6}\right)$ & $3\left(3 \times 10^{3}\right)$ & $100\left(1 \times 10^{5}\right)$ & $1 \quad\left(1 \times 10^{3}\right)$ \\
\hline
\end{tabular}

a The $\mathrm{K}_{\mathrm{d}}$ value in units of $\mathrm{m}^{3} / \mathrm{kg}$ (i.e., $\mathrm{Bq} / \mathrm{m}^{3} \div \mathrm{Bq} / \mathrm{kg}$ ) must be multiplied by 1,000 to obtain a unitless value (i.e., assuming a density of water of $1,000 \mathrm{~kg} / \mathrm{m}^{3}$ ).

b IAEA-MEL recommended $K_{d}$ ranges for Kara Sea sediments based on sediment-water measurements.

c Average of distribution coefficients reported for three Kara Sea sediments.

d Recommended value for coastal waters.

The impact of $\mathrm{K}_{\mathrm{d}} \mathrm{s}$ in contaminant transport models further depends upon the mass of sediment in seawater. In a system with low-particle loading (even with a high $\mathrm{K}_{\mathrm{d}}$ ), uptake has less of an impact on contaminant concentrations simply because of the differences in mass of the two phases. However, in a system with high-particle loading, such as in fjords, the mass of solids can be large. In this case quantification of $K_{d}$ and understanding its behavior as a function of particle loading becomes much more critical than in a system depleted of particles (Carroll and Harms, 1997). Estimating the distribution of each radionuclide between its dissolved and particulate phases in a unit volume of water will provide more clarification on the importance of particle-scavenging processes that control the accumulation of radionuclides in sediments (from Eq. 3-5). If the RAIG uses a particle loading of $5 \mathrm{mg} / \mathrm{L}\left(0.005 \mathrm{~kg} / \mathrm{m}^{3}\right)$, less than $2 \%$ of the radioactivity of ${ }^{137} \mathrm{Cs}$ and ${ }^{90} \mathrm{Sr}$ in seawater will be associated with the particulate phase-even using the highest $K_{d} s$ in Table 31. The most particle-reactive nuclide, ${ }^{241} \mathrm{Am}$, would only have $9 \%$ of its activity associated with the water phase, based on the IAEA (1985) recommended $K_{d}$ for coastal waters. But with the lower $K_{d}$ measured for Kara Sea sediments $\left(-100 \mathrm{~m}^{3} / \mathrm{kg}\right)$, the fraction dissolved in water increases to $67 \%$. For ${ }^{239} \mathrm{Pu}$, the fractions dissolved in water range from 67 to $91 \%$ for particle loadings of 0.005 to $0.001 \mathrm{~kg} / \mathrm{m}^{3}$. In the central Arctic Ocean, where suspended particle loadings are apparently much lower, the fraction of the particle-reactive nuclides in the dissolved phase would be even higher.

Implications of these findings to the transport modeling of radionuclides in the RAIG CM are the following. The calculated distributions of the dissolved/particulate fractions indicate that ${ }^{137} \mathrm{Cs}$ and ${ }^{90} \mathrm{Sr}$ will behave as conservative tracers in seawater, with very limited particle scavenging from the water column. The more particle-reactive radionuclides, ${ }^{241} \mathrm{Am}$ and ${ }^{239} \mathrm{Pu}$, will be partially scavenged from the water column. As a result, their concentration levels will depend in part on spatial variations of particulate matter concentration along transport routes leading from the Kara Sea dumpsites to other Arctic waters. The RAIG performed more tests on the RAIG CM to evaluate model sensitivities to $K_{d}$ values, which are discussed later in Section 3. 


\subsubsection{Sediment-Related Transport Processes}

As demonstrated in the previous subsection, the existence of sediment in Arctic seas influences the fate and transport of particle-reactive radionuclides such as plutonium and americium. Sedimont-related transport processes operating in the world's oceans include passive transport of particles by ocean currents, particle settling to deeper layers of the ocean or to the seafloor, particle resuspension from the scafloor by physical and biological mechanisms and permanent burial (Figure 3-1). The amount and composition of sediments varies from location to location on the seafloor in response to changes in the relative impact of each of the sediment-related processes. And yet, over very long timescales, the net impact of these processes is a loss of particles from the water column to the ocean floor. In conjunction with particle transport through the oceans, radionuclides themselves may undergo a variety of chemical transformations (Hamilton et al., 1994; Smith et al., 1994; Buesseler and Sholkovitz, 1987; Aarkrog et al., 1987). However, along with a net loss of particles to the seafloor, there will be an associate net loss of particle-reactive radionuclides (Smith et al., 1995; Hamilton et al., 1994).

In contaminant transport modeling, the simplest and most common approach used to account for the removal of radionuclides from seawater by particle deposition to the seabed is to employ a two-step approach. First, the distribution coefficient is used to predict the radionuclide concentration in seawater and on particles, then particles are removed from the system in accordance with the rate of particle deposition on the seabed. As previously discussed in this report, distribution coefficients have been determined for the Kara Sea. In the remainder of this section, information is presented on the distribution of particles and particle deposition rates in Arctic seas.

Although there are limited data on the levels of suspended particles in the Arctic Ocean, it is well-known that particle transport does not result in a uniform distribution of sediments throughout the Arctic Ocean. Ivanov (1994) reported values of 3 to $5 \mathrm{mg} / \mathrm{L}\left(0.003\right.$ to $\left.0.005 \mathrm{~kg} / \mathrm{m}^{3}\right)$ for the Barents Sea and an average of $3.5 \mathrm{mg} / \mathrm{L}\left(0.0035 \mathrm{~kg} / \mathrm{m}^{3}\right)$ for the Kara Sea. Higher levels of suspended solids are associated with the bays along the Novaya Zemlya coastline, because of tidal and wave action that suspends sediments into the water column. Baskaran and Naidu (1995) reported particle loadings ranging from 0.03 to $0.96 \mathrm{mg} / \mathrm{L}\left(0.00003\right.$ to $\left.0.00096 \mathrm{~kg} / \mathrm{m}^{3}\right)$ for the Chukchi Sea, but Bacon et al. (1989) measured concentrations of suspended matter below 0.01 $\mathrm{mg} / \mathrm{L}\left(<0.00001 \mathrm{~kg} / \mathrm{m}^{3}\right)$ at an ice station located in the central Arctic basin $\left(\right.$ at $85^{\circ} 50^{\prime} \mathrm{N}, 108^{\circ}$ $\left.50^{\prime} \mathrm{W}\right)$.

As a consequence of variable particle concentrations, particle deposition rates in Arctic seas range from $\mathrm{mm} / \mathrm{yr}$ in the shallow Kara Sea to $\mathrm{mm} / \mathrm{ky}$ in the deepest regions of the Arctic ocean. Radionuclides associated with dumped nuclear reactors will first be released into the Kara Sea. Hamilton et al. (1994) conducted a radiometric investigation of the Kara Sea sediments to determine the distribution of selected radionuclides in sediments and to estimate burial rates of sediment. They estimated burial rates by using ${ }^{210} \mathrm{~Pb}$ as a natural tracer to date the age of sediments at different depths. The estimated rates (assuming that resuspension is negligible compared with deposition) ranged from 1.6 to $2.3 \mathrm{~mm} / \mathrm{yr}$, based on a sediment porosity of 0.86 . These values are comparable to the sedimentation rates of 1 to $2 \mathrm{~mm} / \mathrm{yr}$ estimated for Bylot Sound by Smith et al. (1994). Hamilton et al. also found that surficial sediments were well mixed in a shallow zone of a few centimeters in thickness.

The result of these variations in particle concentrations and deposition rates throughout the Arctic ocean is that sediments are non-uniformly distributed on the seabed. It is possible for contaminated sediments to be concentrated within specific subregions of the Arctic, such as on continental shelves (Baskaran et al., 1996; Cooper et al., 1995). If deposition is enhanced in regions 
rich in biological resources, there is the potential for radionuclides to be more readily available for transfer into Arctic food webs. In compartmental models, a single particle concentration and deposition rate is assigned to each model compartment. As a result, the influence of smaller-scale variations in particle concentrations and deposition rates are not reflected in the results of the modeling exercises.

\subsubsection{Role of Ice Transport}

The following discussion provides perspective on sea ice-related processes and the importance of sea ice transport in relation to other radionuclide transport mechanisms operating in Arctic seas. The important mechanisms influencing radionuclide transport by sea ice are: (1) sediment incorporation into sea ice during sea ice formation; (2) radionuclide uptake into sea ice and by sea ice sediment; and (3) transport pathways for sea ice in Arctic seas. Given present limitations in knowledge of sea ice processes, simulations of sea ice and associated radionuclide transport were not included in the regional-scale compartmental model the RAIG team used. A simple comparison of water, sediment, and sea-ice transport, however, strongly suggests that the primary pathway for exchanging radionuclides among Arctic seas is water transport.

Direct observations have shown that sea ice incorporates and transports sediment (Nurnberg et al., 1994; Reimnitz et al., 1993; Kempema et al., 1989). The incorporation of sediments into sea ice is thought to occur primarily along the shallow circum-Arctic shelves at water depths generally less than $50 \mathrm{~m}$, where levels of suspended sediments are highest because of the action of waves and currents on bottom sediments. One potential mechanism of sediment incorporation into ice is the scavenging of suspended sediment by frazil ice crystals in the water column (Pfirman et al., 1997). The interactions of ice with bottom sediments as well as wave overwashing of ice also may result in the incorporation of sediment in ice.

Mechanisms influencing the incorporation of radionuclides by sea ice are receiving more attention from investigators, primarily in response to recent concerns over Arctic nuclear waste. A comparison of recent data from ice formation experiments conducted at the Cold Regions Research and Engineering Laboratory (D. Meese, personal communication) and ${ }^{137} \mathrm{Cs}$ concentrations determined from Arctic sea-ice samples provide preliminary information to evaluate these mechanisms. These researchers collected samples of sea ice containing sediment and "clean ice" along a cruise transect from the Chukchi Sea to the North Pole. They determined high ${ }^{137} \mathrm{Cs}$ concentrations $(5-73 \mathrm{~Bq} / \mathrm{kg} \mathrm{dw})$ for the sea-ice sediment samples and low ${ }^{137} \mathrm{Cs}$ concentrations $(<1$ $\mathrm{Bq} / \mathrm{m}^{3}$ ) for samples of non-sediment-rich or "clean ice" (Meese et al., 1997). Interestingly, the "clean ice" ${ }^{137} \mathrm{Cs}$ concentrations were even lower than ambient-seawater concentrations (2-15 $\mathrm{Bq} / \mathrm{m}^{3}$; Ellis et al., 1995). Data from the ice-freezing experiments suggest that the ice rejects radionuclides during the freezing process in a manner similar to brine rejection.

The role that ice plays in the transport of radionuclides from the Kara Sea to other Arctic seas is further dependent upon the transport pathways for sediment-laden ice. Various techniques are under development to identify these pathways. One such method is to compare data on the sediment composition of sea ice with sediment samples from various coastal and ocean locations (Meese et al., 1997; Darby and Bischof, 1996). Analyses of iceborne sediment collected in the Beaufort and Chukchi Seas indicate that potential source areas are along the Russian shelves. An alternative technique involves the simulation of "backward" ice trajectories interpolated from current velocity fields determined from analyses of the movements of drifting ice buoys (Rigor and Colony, 1997). Simulations of the mean field of ice motion in the Arctic Ocean for the years 
1979 to 1994 (provided by I. Rigor) suggest that the regional flow of ice is toward the Greenland Sea via the Fram Strait (Figure 3-2).

As previously noted, much of the data needed to establish the role of sca-ice transport as a distribution mechanism for radionuclides are still preliminary. Simple calculations comparing the relative magnitude of water, sediment, and ice transport from the Kara Sea provide some perspective on the relative importance of sea-ice transport as a conveyor of contaminated sediment to other Arctic seas. Rigor (personal communication) estimates that $2.1 \times 10^{5} \mathrm{~km}^{2}$ of sea ice arc produced annually in the shallow waters of the Kara Sea. Based on an ice thickness of $2 \mathrm{~m}$ and $2.1 \times 10^{4} \mathrm{~km}^{2}$ of ice exported (i.e., $10 \%$ of the $2.1 \times 10^{5} \mathrm{~km}^{2}$ of ice formed in shallow waters), the annual volume of ice exported from the Kara Sea is approximately $40 \mathrm{~km}^{3}$. Assuming an elevated sediment loading of $100 \mathrm{mg} / \mathrm{L}\left(0.1 \mathrm{~kg} / \mathrm{m}^{3}\right), 4 \times 10^{6}$ tonnes of sediment are exported annually to adjacent Arctic seas. The Kara Sea as a whole contains approximately $1.3 \times 10^{5} \mathrm{~km}^{3}$ of water and $4.6 \times 10^{8}$ tonnes of suspended sediment (using an average suspended sediment loading of $3.5 \mathrm{mg} / \mathrm{L}(0.0035 \mathrm{~kg} /$ $\mathrm{m}^{3}$ ). With a residence time of water in the Kara Sea of about 3.5 years (Pavlov et al., 1996), and a rate constant for water exchange of $0.29 / \mathrm{yr}$ (i.e., calculated as the inverse of the residence time or $1 / 3.5 \mathrm{yr}$ ), the approximate water ventilation rate is $3.8 \times 10^{4} \mathrm{~km}^{3} / \mathrm{yr}$ (i.e., $0.29 / \mathrm{yr} \times 1.3 \times 10^{5} \mathrm{~km}^{3}$ ). The associated sediment load advected from the Kara Sea is $1.3 \times 10^{8}$ tonnes of sediment each year.

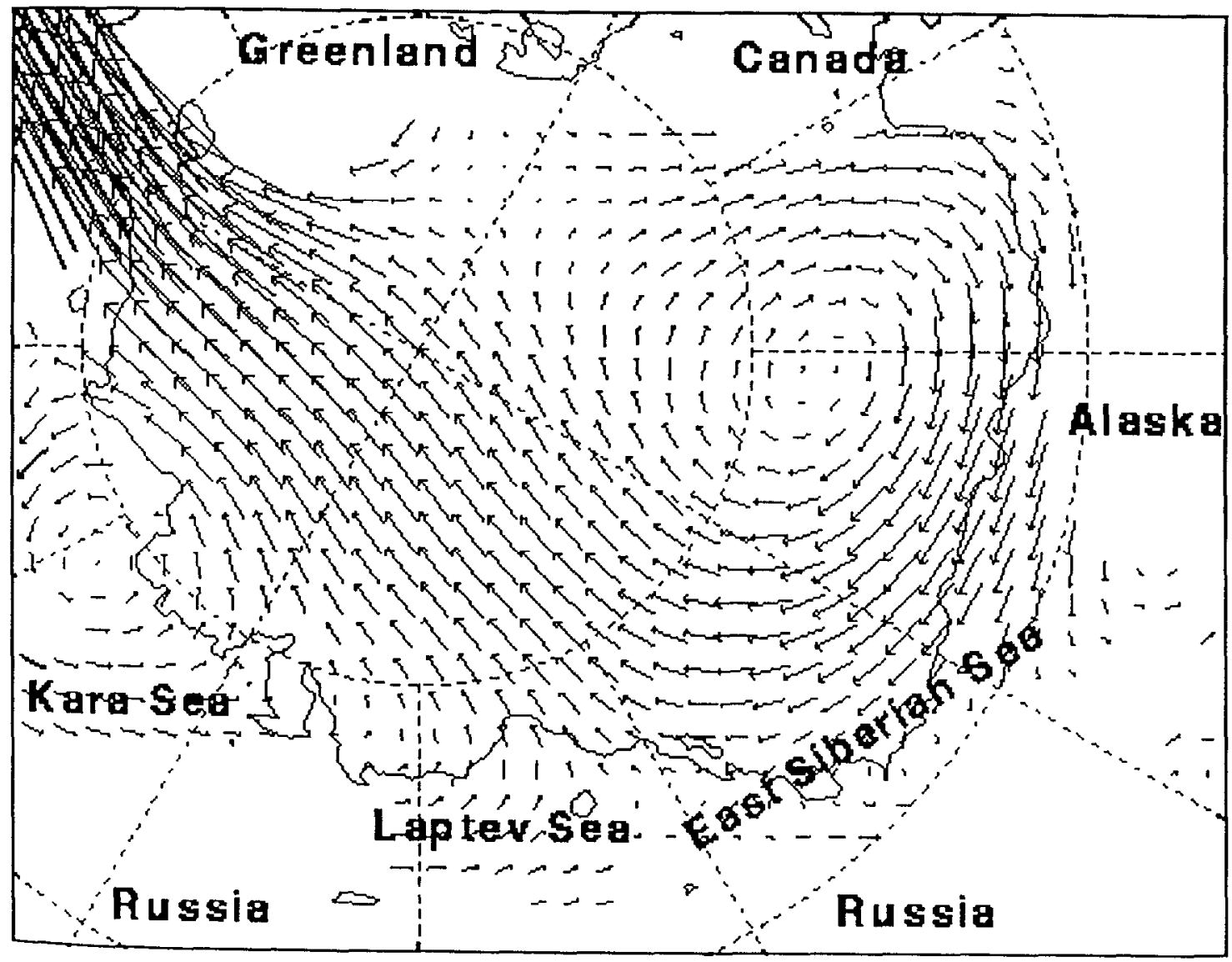

Figure 3-2. Mean field of ice motion in the Arctic Ocean for the years 1979 through 1994. 
Comparing the annual flux of seawater from the Kara Sea $\left(3.8 \times 10^{4} \mathrm{~km}^{3}\right)$ to the masses of sediment transported annually by seawater $\left(1.3 \times 10^{8}\right.$ tonnes $)$ and ice $\left(4 \times 10^{6}\right.$ tonnes $)$, the masses of sediment are minimal. The amounts of radionuclides transported by attachment to these masses of sediment will be correspondingly small. Should releases from nuclear wastes in the Kara Sea occur, the largest quantities of radionuclides will be exchanged by water transport to adjacent Arctic seas.

\subsection{Transport Simulations: The RAIG and Nielsen et al. (1995) Compartmental Models}

The transport simulations conducted as part of the ANWAP risk assessment are based on a compartmental transport model developed by the RAIG. The group also has implemented a modified version of a compartmental model developed by Nielsen et al. (1995) for assessing radionuclide transport in the Arctic Ocean in order to establish benchmarks with another assessmentlevel model. Below are descriptions of the basic attributes of the two models.

\subsubsection{RAIG Compartmental Model}

The compartmental model (CM) developed by the RAIG is a numerical formulation that simulates radionuclide transport by solving the basic system of coupled mass-balance equations, defined by Eq. 3-1, for multiple compartments throughout the Arctic Ocean. The RAIG CM has a compartmental structure consisting of boxes that represent the Arctic Ocean's major seas and the Bering Sea. Compartment volumes and depths were based on analyses of bathymetric data, while water exchanges were determined from simulations of ocean currents via a three-dimensional, coupled ocean-ice model (Cheng and Preller, 1996). The commercially available software package, STELLA II [High Performance Systems Inc., 45 Lyme Road, Hanover, NH, 03755], was used to solve the set of linked ordinary differential equations representing the various compartments. The modeling system developed is able to simulate instantaneous or time-varying releases of a radionuclides in a given source compartment, such as the Kara Sea.

\section{Compartmental Configuration}

The basic compartmental structure of the RAIG model was developed at a workshop in Sequim, Washington (Oct. 16-18, 1995), that dealt primarily with the use of various kinds of models to assess the impacts of nuclear wastes in the Arctic Ocean. Important objectives for developing the compartmental structure were to define compartments that (1) could be used to assess the transport of radionuclides from given sources (primarily nuclear wastes in the Kara Sea, and secondarily, the Northwest Pacific Ocean) to Alaskan waters and (2) reflect the major ocean basins and circulation patterns in the Arctic Ocean. The compartmental structure that emerged from the workshop covered sub-Arctic and Arctic waters from the Aleutian Islands and Bering Sea to the Norwegian and Greenland Seas. This extended domain was defined in order to provide a capability for assessing potential impacts over a wide region, although the focus was on Alaska. For example, the RAIG model includes several compartments along the north coast of the FSU from the Kara Sea to the Chukchi Sea to address a potential transport pathway from the Kara Sea to Alaskan waters. Compartments along the FSU and Alaskan Coasts include separate coastal and 
shelf regions. The coastal regions are defined roughly as those waters extending outward from the coastline to a depth of $50 \mathrm{~m}$. The shelf regions extend outward from this $50 \mathrm{~m}$ depth to the approximate location where the shelf drop-off begins. This includes water from 50 to $1,000 \mathrm{~m}$ decp. Four factors lead to extension of the model domain to the Aleutian Islands: (1) the migratory patterns of some of the marine mammals which extend to the Aleutians, (2) coastal populations south of the Arctic Circle, which are included in the assessment, (3) the Aleutians form a logical boundary between the North Pacific and the Bering Sea, and (4) it could accommodate the possibility of including a radionuclide release in the Northwest Pacific Ocean.

Figure 3-3 depicts the 21 compartmental regions, some of which are stacked two deep in the vertical direction. The boundary between vertical regions is approximately at the $500 \mathrm{~m}$ depth level. Exchanges occur between adjacent regions both in the horizontal and vertical direction. Radionuclide releases occur in the Kara Sea estuary, compartment 7, to represent inputs from the $\mathrm{Ob}$ and Yenisey rivers, and compartment 8 is used as the source compartment for releases from nuclear wastes in the Kara Sea, including bays along the coast of Novaya Zemlya. An additional release from the Northwest Pacific Ocean is treated as a boundary condition along the Southern Bering Sea/Aleutian boundary.

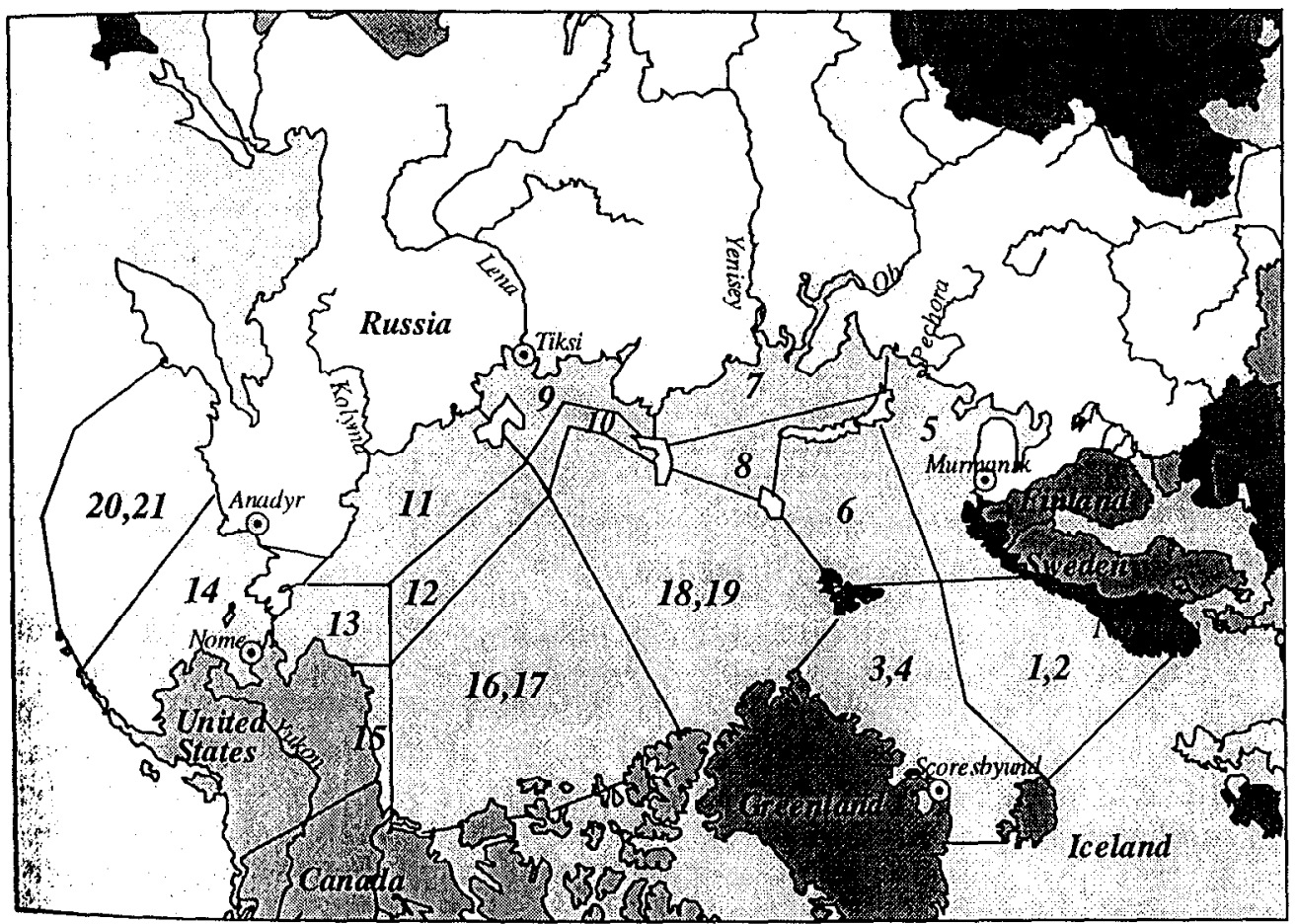

Figure 3-3.

Locations of the water compartments uscd in the RAIG model. Two numbers designate areas that include two stacked boxes to represent a vertical section of the ocean: the first number represents the upper compartment, and the second one the lower compartment.

A diagram in Figure 3-4 shows the connectivity among the various compartments. This connectivity defines which compartments interact and influence the behavior of other compartments. Additional data describe the boundary conditions. These boundaries define the physical extent of the region considered for the Arctic risk assessment. It is across these boundaries that interaction to other ocean regions may occur and influence the results. In the RAIG model, interaction between the Arctic and Pacific oceans occurs at compartments 14, 20, and 21 in the Bering Sea. Interactions between the Arctic and Atlantic oceans occur at compartments 1 and 2 (the Norwegian Sea), 3 and 4 (the Greenland Sea), and 16 (adjacent to the Canadian archipelago). 


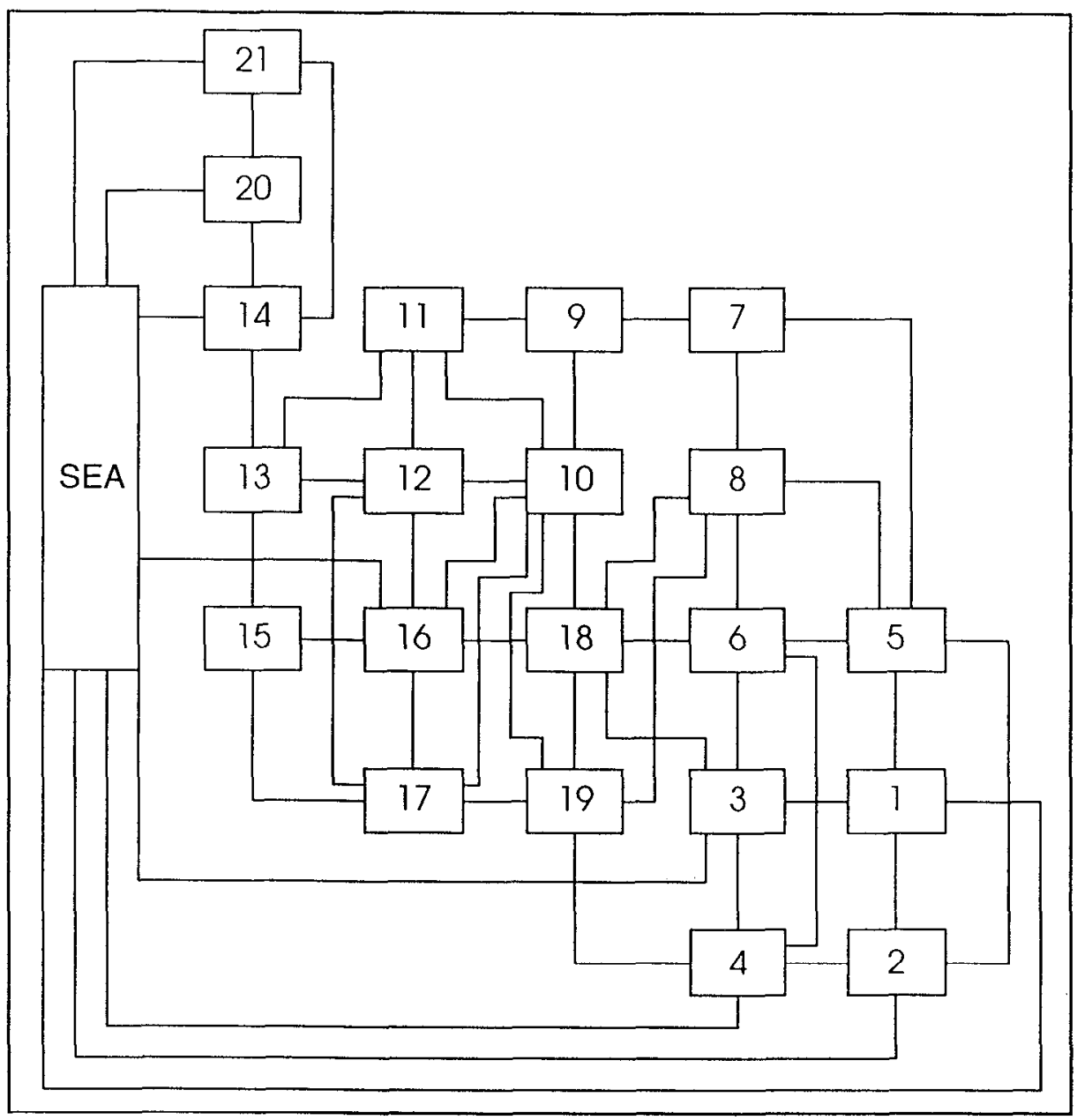

Figure 3-4. Water exchanges between ocean compartments in the RAIG model.

\section{Parameterization of Compartmental Input Variables}

The accurate characterization of water movements between boxes is perhaps the most important part of implementing a compartmental model. Usually, water flows are estimated from oceanographic data covering the waters being assessed (e.g., Evans, 1985). However, even with such data it can be difficult to quantify the water exchanges between several compartments. The water exchanges in the RAIG CM were determined by a methodology developed by Marietta and Simmons (1988), who used an ocean-circulation model (OCM) to determine the water flows between compartments. In their approach the researchers first run an OCM to determine the threedimensional flow of water through the ocean region being assessed, and then process the results of that simulation to provide the water flows across the specific ocean compartments used to represent the assessment domain. Flows also can be adjusted, as appropriate, to reflect oceanographic data on various currents in the region being assessed. Nielsen et al. (1995) also adopted this approach for the development of a CM of the Arctic Ocean.

Once the compartmental structure of the RAIG model was defined, the next step in model implementation was to determine the volumes and depths of the compartments and the water exchange rates between compartments. The keys to determining the values of these parameters were a coupled ice-ocean computer model implemented by Cheng and Preller (1996) to determine the movement of water in the seas representing the assessment domain, and special soft- 
ware for rapidly analyzing the input and output files of the ice-ocean circulation model to determine the inputs to the RAIG CM.

The coupled ice-ocean model used to simulate the movement of sea ice and ocean currents is based on the coupling of the Hibler ice model (Hibler, 1979, 1980) to the Cox (1984) ocean model. The equations used by both models are defined in spherical coordinates. The model grid has been transformed and rotated to avoid a numerical singularity at the grid point representing the North Pole. Cheng and Preller (1996) give a detailed description of the model equations written in spherical coordinates and the grid transformation. The model was originally designed to include all sea-ice-covered regions in the northern hemisphere and extends from the pole to approximately $30^{\circ} \mathrm{N}$ latitude. This domain includes those seas with a partial sea-ice cover such as the Sea of Okhotsk, Sea of Japan, and the Yellow Sea. It also includes the Labrador Sea, Hudson Bay, Baffin Bay, and the East Greenland and Barents seas on the Atlantic side. The horizontal grid resolution of the model is 0.28 degrees. The model uses fifteen levels to resolve the depth of the ocean. The first level is shallowest and extends to $30 \mathrm{~m}$ depth. The thickness of each level increases with depth. The ETOPO5 bathymetry data helps define the model geometry and bathymetry. Several channels and straits are artificially closed when this data is averaged onto the model grid (i.e., the channel connecting the Baltic to the North Sea). In addition, some islands, adjacent to deep trenches, are averaged in such a way that they become sea points. Several such problem areas have been edited manually and corrected. Manual editing to open several straits (i.e., the Kara Gate) also has resulted in artificially widening these straits. Many of the Aleutian and Kuril Islands had to be edited manually back into the model geometry.

The ice and ocean models are coupled by exchanging necessary heat and salinity flux as well as interfacial stress information. Two of the ocean-model equations that use daily ice-model information are the temperature and salinity equations. The temperature equation follows:

$$
\frac{\partial \mathrm{T}}{\partial t}+\nabla \bullet(\mathbf{u T})=\mathrm{K}_{\mathrm{H}} \nabla^{2} \mathrm{~T}+\mathrm{K}_{\mathrm{Z}} \frac{\partial^{2} \mathrm{~T}}{\partial \mathrm{z}^{2}}-\frac{\mathrm{f}_{\mathrm{A}} \delta(\mathrm{z}) \mathrm{R}_{0} \theta\left(\mathrm{T}-\mathrm{T}_{\mathrm{f}}\right)}{\mathrm{Z}_{\text {mix }}}-\mathrm{R}_{\mathrm{t}}\left(\mathrm{T}-\mathrm{T}_{0}\right)
$$

where

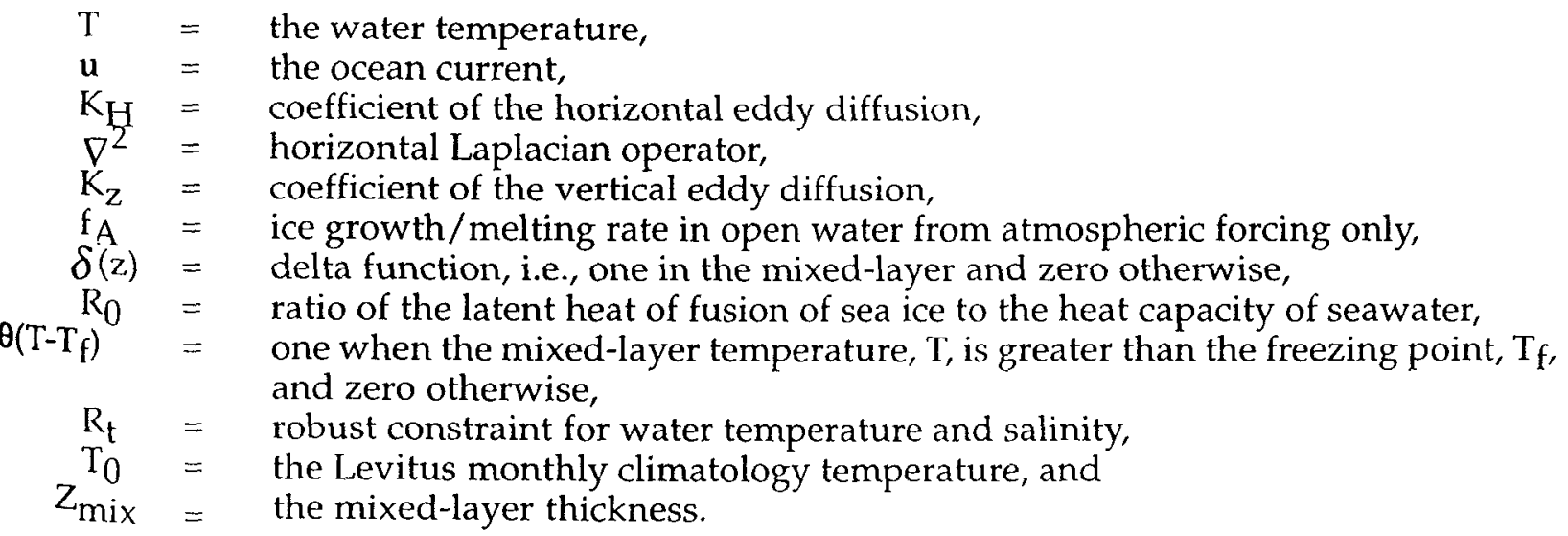


The robust constraint, as defined by Sarmiento and Brian (1982), is set at 250 days. This is sufficient to keep the ocean temperature and salinity from dissipating because of eddy diffusion, but also allows the atmospheric heating and cooling effects to penetrate into the upper layer of the ocean model.

The salinity equation used in the ocean model is

$$
\frac{\partial S}{\partial \mathrm{t}}+\nabla \cdot(\mathrm{uS})=\mathrm{K}_{\mathrm{H}} \nabla^{2} \mathrm{~S}+\mathrm{K}_{\mathrm{Z}} \frac{\partial^{2} \mathrm{~S}}{\partial \mathrm{z}^{2}}-\frac{0.035 \mathrm{~S}_{\mathrm{f}} \delta(\mathrm{z})}{\mathrm{Z}_{\mathrm{mix}}}-\mathrm{R}_{\mathrm{t}}\left(\mathrm{S}-\mathrm{S}_{0}\right)
$$

where

$$
\begin{aligned}
& \mathrm{S}_{\mathrm{f}} \quad \text { salinity, } \\
& \mathrm{S}_{\mathrm{f}}=\text { total ice growth rate in open water, and } \\
& \mathrm{S}_{0}=\text { the Levitus monthly climatology salinity. }
\end{aligned}
$$

A similar robust constraint is used in the salinity equation. The freezing temperature used in the model is dependent on the salinity as defined by the following equation:

$\mathrm{T}_{\mathrm{f}}=-54.4 \mathrm{~S}$,

where $S$ is the salinity. The mixed layer oceanic heat fluxes are defined as the heat advected and diffused into each grid cell, and have the following forms:

$$
-\nabla \cdot(\mathbf{u T}), \mathrm{K}_{\mathrm{H}} \nabla^{2} \mathrm{~T}, \mathrm{~K}_{\mathrm{z}} \frac{\partial^{2} \mathrm{~T}}{\partial \mathrm{z}^{2}}
$$

each multiplied by the water mass and its heat capacity. Vertical mixing and vertical heat convection in the Cox ocean model take place whenever large enough density differences develop. In the coupled model, the mixed-layer temperature depends on the open water condition. If the open water starts to grow sea ice, then the mixed-laycr temperature is set at the freezing point. The open water does not grow sea ice if the atmospheric and oceanic heat fluxes are not cold cnough. They simply reduce the mixed-layer tempcrature. In the melting seasons, these heat fluxes warm up the mixed-layer or melt the existing sea ice. In coupling the ice and ocean models, sea ice is treated as a boundary layer blocking direct heat and momentum exchanges between the atmosphere and ocean. Surface wind stress passes momentum to the sea ice, some of which moves the sea ice, while another part transfers into the internal ice. Sea-ice motion is applied as a stress to the top layer of the ocean.

A variable drag coefficient between sea ice and water was applied based on the boundary layer theory of McPhee (1990):

$$
C_{\text {diw }}=\left(\frac{1}{k} \ln \left(\frac{h}{z_{0}}\right)\right)^{-2}
$$


where

$\mathrm{C}_{\text {diw }}$ is the coefficient,

$\mathrm{k}=$ the von Karmon constant, 0.41;

$\mathrm{z}_{\mathrm{O}}=$ the ice roughness $(0.01 \mathrm{~m})$; and

$\mathrm{h}=$ the ice thickness, which is set to be greater than $z_{O}$ at all times.

When $\mathrm{h}$ is equal to 2.5 meters, the drag coefficient is equal to the constant value used by Hibler (1979), 0.0055. Note that the drag coefficient decreases as the ice thickness increases, i.e., there is very little drag stress on thick ice from water. On the other hand, the drag stress becomes the dominant factor over wind stress when $h$ is small and very close to $z_{o}$.

Numerical model experiments are run in the following way. In the coupled case, the model is initialized from a fall "model climatology" based on the model results using 1986 atmospheric forcing (i.e., wind-generated ocean currents) from the U.S. Navy's global atmospheric model, the Navy Operational Global Atmospheric Prediction System (NOGAPS). In the uncoupled case, the ocean model is "spun up" from Levitus climatology by running it for 5 years using a mean wind. In both cases, the model boundaries in the Atlantic and Pacific oceans are all treated as "closed" boundaries. The model calculation from which these transports were determined used the following parameters: horizontal eddy diffusion $=10^{6} \mathrm{~cm}^{2} / \mathrm{s}$, vertical eddy diffusion $=1 \mathrm{~cm}^{2} / \mathrm{s}$, horizontal eddy viscosity $=10^{8} \mathrm{~cm}^{2} / \mathrm{s}$, and the vertical eddy viscosity $=1 \mathrm{~cm}^{2} / \mathrm{s}$. The time step used in this model run was 1 hour for temperature and salinity and 6 minutes (0.1 hour) for the stream function and ocean currents (i.e., the distorted physics method of Bryan (1984)).

To expedite the process of converting the ocean-model results for the three-dimensional simulations to water exchange rates between compartments in the RAIG CM, the RAIG developed an automated process that divides the ocean into compartments, sums areas and volumes, and then computes water exchanges (implemented as a computer program, termed PFIG). The automated process allows an analyst to define arbitrary polygons within the Arctic Ocean and uses bathymetry data and water circulation predictions from the ocean circulation model to create the necessary transfer rates for the RAIG CM.

Table 3-2 shows the compartmental volumes and depths for the various compartments in the RAIG model obtained from the PFIG software. Table 3-3 presents water exchanges between the various compartments (based on the ocean-current predictions from the coupled ice-ocean model). The original water flux predicted by the ocean circulation model for the Bering Strait was considerably lower than the measured current of $0.89 \times 10^{6} \mathrm{~m}^{3} / \mathrm{s}$ (Roach et al., 1995). To compensate for this underprediction, the RAIG increased the flow of Pacific Ocean water from the Bering Sea to the Chukchi Sea to $1 \times 10^{6} \mathrm{~m}^{3} / \mathrm{s}$, and routed this additional flow through adjacent compartments so that it exits the Arctic Ocean via the Canadian archipelago (see Table 3-3). 
Table 3-2. Data on compartment volumes, depths, sediment loadings, and sediment deposition for the RAIG compartmental model.

\begin{tabular}{lccccc}
\hline \multicolumn{1}{c}{ Region } & $\begin{array}{c}\text { Box } \\
\text { Id }\end{array}$ & $\begin{array}{c}\text { Volume } \\
\mathrm{m}^{3}\end{array}$ & $\begin{array}{c}\text { Depth } \\
\mathrm{m}\end{array}$ & $\begin{array}{c}\text { Sediment Load } \\
\mathrm{t} / \mathrm{m}^{3}\end{array}$ & $\begin{array}{c}\text { Sedimentation } \\
\text { Rate } \\
\mathrm{t} / \mathrm{m}^{2}-\mathrm{y}\end{array}$ \\
\hline Norwegian Sea, upper & 1 & $5.0 \times 10^{14}$ & $4.6 \times 10^{2}$ & $1 \times 10^{-6}$ & $1 \times 10^{-4}$ \\
Norwegian Sea, lower & 2 & $1.9 \times 10^{15}$ & $1.7 \times 10^{3}$ & $1 \times 10^{-6}$ & $2 \times 10^{-5}$ \\
Greenland Sea, upper & 3 & $4.8 \times 10^{14}$ & $4.3 \times 10^{2}$ & $1 \times 10^{-6}$ & $1 \times 10^{-4}$ \\
Greenland Sea, lower & 4 & $1.5 \times 10^{15}$ & $1.4 \times 10^{3}$ & $1 \times 10^{-6}$ & $2 \times 10^{-5}$ \\
Barents Sea, South & 5 & $1.3 \times 10^{14}$ & $2.3 \times 10^{2}$ & $6 \times 10^{-6}$ & $1 \times 10^{-3}$ \\
Barents Sea, North & 6 & $2.3 \times 10^{14}$ & $2.8 \times 10^{2}$ & $6 \times 10^{-6}$ & $5 \times 10^{-4}$ \\
Kara Sca, estuary & 7 & $2.9 \times 10^{13}$ & $7.3 \times 10^{1}$ & $3 \times 10^{-6}$ & $1 \times 10^{-3}$ \\
Kara Sea & 8 & $1.0 \times 10^{14}$ & $2.7 \times 10^{2}$ & $6 \times 10^{-6}$ & $3 \times 10^{-4}$ \\
Laptev Sea, coastal & 9 & $2.4 \times 10^{13}$ & $5.1 \times 10^{1}$ & $3 \times 10^{-6}$ & $1 \times 10^{-3}$ \\
Laptev Sea, shelf & 10 & $1.6 \times 10^{14}$ & $9.7 \times 10^{2}$ & $1 \times 10^{-6}$ & $1 \times 10^{-4}$ \\
East Siberian Sea, coastal & 11 & $4.4 \times 10^{13}$ & $6.0 \times 10^{1}$ & $3 \times 10^{-6}$ & $1 \times 10^{-3}$ \\
East Siberian Sea, shelf & 12 & $2.6 \times 10^{14}$ & $6.4 \times 10^{2}$ & $1 \times 10^{-6}$ & $1 \times 10^{-4}$ \\
Chukchi Sea & 13 & $2.3 \times 10^{13}$ & $7.3 \times 10^{1}$ & $3 \times 10^{-6}$ & $1 \times 10^{-3}$ \\
Bering Sea, North & 14 & $6.7 \times 10^{13}$ & $9.8 \times 10^{1}$ & $3 \times 10^{-6}$ & $1 \times 10^{-3}$ \\
Beaufort Sea & 15 & $7.7 \times 10^{13}$ & $6.6 \times 10^{2}$ & $1 \times 10^{-6}$ & $1 \times 10^{-4}$ \\
Amerasian Basin, upper & 16 & $1.3 \times 10^{15}$ & $4.6 \times 10^{2}$ & $1 \times 10^{-6}$ & $1 \times 10^{-4}$ \\
Amerasian Basin, lower & 17 & $5.6 \times 10^{15}$ & $2.0 \times 10^{3}$ & $1 \times 10^{-6}$ & $2 \times 10^{-5}$ \\
Eurasian Basin, upper & 18 & $1.0 \times 10^{15}$ & $4.8 \times 10^{2}$ & $1 \times 10^{-6}$ & $1 \times 10^{-4}$ \\
Eurasian Basin, lower & 19 & $5.6 \times 10^{15}$ & $2.6 \times 10^{3}$ & $1 \times 10^{-6}$ & $2 \times 10^{-5}$ \\
Bering Sea South, upper & 20 & $5.5 \times 10^{14}$ & $4.8 \times 10^{2}$ & $1 \times 10^{-6}$ & $1 \times 10^{-4}$ \\
Bering Sea South, lower & 21 & $3.0 \times 10^{15}$ & $2.6 \times 10^{3}$ & $1 \times 10^{-6}$ & $2 \times 10^{-5}$ \\
Sea & 22 & $1.0 \times 10^{18}$ & $3.4 \times 10^{3}$ & $1 \times 10^{-6}$ & $2 \times 10^{-5}$ \\
\hline
\end{tabular}

The combination of compartmental volume and related exchange rates between compartments are the inputs required to calculate rate constants (Eq. 3-2) for simulating the transfer of radionuclides between compartments. The depth of a compartment, the mass loading of particulate matter, the sedimentation rate, and $\mathrm{K}_{d}$ of a radionuclide are required to determine the rate constants for particle scavenging (Eq. 3-3). For the transport simulations, the RAIG used a $K_{d}$ of $100 \mathrm{~m}^{3} / \mathrm{kg}$ for both ${ }^{241} \mathrm{Am}$ and ${ }^{239} \mathrm{Pu}$, as there was insufficient data to distinguish between the values summarized in Table 3-1 for these two radionuclides. The $\mathrm{K}_{d}$ s presented in Table 3-1 for ${ }^{137} \mathrm{Cs}$ and ${ }^{90} \mathrm{Sr}$ were considerably smaller than those for ${ }^{241} \mathrm{Am}$ and ${ }^{239} \mathrm{Pu}$. The RAIG selected values of 0.1 and $0.004 \mathrm{~m}^{3} / \mathrm{kg}$ to represent ${ }^{137} \mathrm{Cs}$ and ${ }^{90} \mathrm{Sr}$. These values constitute reasonable and conservative lower bounds, which means that most of the radioactivity for these two nuclides would be associated with the dissolved phase. 
Table 3-3. Volumetric exchanges of water between compartments of the RAIG compartmental model. Values have been rounded to two significant figures.

\begin{tabular}{|c|c|c|c|c|c|c|c|c|}
\hline $\begin{array}{c}\text { From } \\
\text { box }\end{array}$ & $\begin{array}{c}\text { To } \\
\text { box }\end{array}$ & $\begin{array}{c}\text { Flux } \\
\left(\mathrm{km}^{3} \mathrm{y}^{-1}\right)\end{array}$ & $\begin{array}{c}\text { From } \\
\text { box }\end{array}$ & $\begin{array}{l}\text { To } \\
\text { box }\end{array}$ & $\begin{array}{c}\text { Flux } \\
\left(\mathrm{km}^{3} \mathrm{y}^{-1}\right)\end{array}$ & $\begin{array}{c}\text { From } \\
\text { box }\end{array}$ & $\begin{array}{c}\text { To } \\
\text { box }\end{array}$ & $\begin{array}{c}\text { Flux } \\
\left(\mathrm{km}^{3} \mathrm{y}^{-1}\right)\end{array}$ \\
\hline Sea & 1 & $2.4 \times 10^{5}$ & 9 & 10 & $3.7 \times 10^{4}$ & 19 & 17 & $3.9 \times 10^{5}$ \\
\hline Sea & 2 & $6.8 \times 10^{4}$ & 10 & 9 & $2.4 \times 10^{4}$ & 19 & 18 & $3.6 \times 10^{4}$ \\
\hline Sea & 3 & $2.7 \times 10^{4}$ & 10 & 12 & $5.2 \times 10^{3}$ & 20 & Sea & $2.8 \times 10^{5}$ \\
\hline Sea & 4 & $2.0 \times 10^{2}$ & 10 & 16 & $4.9 \times 10^{3}$ & 20 & 14 & $1.2 \times 10^{5}$ \\
\hline Sea & 14 & $2.0 \times 10^{2}$ & 10 & 17 & $4.8 \times 10^{3}$ & 20 & 21 & $3.3 \times 10^{4}$ \\
\hline Sea & 16 & $5.1 \times 10^{3}$ & 10 & 18 & $8.1 \times 10^{4}$ & 21 & Sea & $3.3 \times 10^{5}$ \\
\hline Sea & 20 & $3.4 \times 10^{5}$ & 10 & 19 & $8.9 \times 10^{4}$ & 21 & 14 & $1.6 \times 10^{3}$ \\
\hline Sea & 21 & $3.0 \times 10^{5}$ & 11 & 9 & $1.4 \times 10^{4}$ & 21 & 20 & $6.2 \times 10^{3}$ \\
\hline 1 & Sea & $5.3 \times 10^{4}$ & 11 & 10 & $1.5 \times 10^{3}$ & & & \\
\hline 1 & 2 & $5.6 \times 10^{4}$ & 11 & 12 & $3.8 \times 10^{4}$ & & & \\
\hline 1 & 3 & $2.3 \times 10^{5}$ & 11 & 13 & $1.0 \times 10^{3}$ & & & \\
\hline 1 & 5 & $8.5 \times 10^{4}$ & 12 & 10 & $5.6 \times 10^{3}$ & & & \\
\hline 2 & Sea & $1.3 \times 10^{5}$ & 12 & 11 & $3.8 \times 10^{4}$ & & & \\
\hline 2 & 1 & $5.5 \times 10^{4}$ & 12 & 13 & $3.3 \times 10^{3}$ & & & \\
\hline 2 & 4 & $1.1 \times 10^{5}$ & 12 & 16 & $1.5 \times 10^{5}$ & & & \\
\hline 2 & 5 & $1.5 \times 10^{3}$ & 12 & 17 & $4.3 \times 10^{4}$ & & & \\
\hline 3 & Sea & $1.4 \times 10^{5}$ & 13 & 11 & $1.6 \times 10^{4}$ & & & \\
\hline 3 & 1 & $1.2 \times 10^{5}$ & 13 & 12 & $4.2 \times 10^{4}$ & & & \\
\hline 3 & 4 & $6.8 \times 10^{4}$ & 13 & 14 & $4.0 \times 10^{2}$ & & & \\
\hline 3 & 6 & $3.9 \times 10^{3}$ & 14 & Sea & $1.0 \times 10^{2}$ & & & \\
\hline 3 & 18 & $9.1 \times 10^{4}$ & 14 & 13 & $3.2 \times 10^{4}$ & & & \\
\hline 4 & Sea & $1.6 \times 10^{4}$ & 14 & 20 & $8.5 \times 10^{4}$ & & & \\
\hline 4 & 2 & $1.6 \times 10^{5}$ & 14 & 21 & $2.4 \times 10^{3}$ & & & \\
\hline 4 & 3 & $2.1 \times 10^{4}$ & 15 & 13 & $2.3 \times 10^{4}$ & & & \\
\hline 4 & 19 & $3.9 \times 10^{4}$ & 15 & 16 & $4.3 \times 10^{4}$ & & & \\
\hline 5 & 1 & $6.8 \times 10^{3}$ & 15 & 17 & $4.6 \times 10^{4}$ & & & \\
\hline 5 & 2 & $2.1 \times 10^{3}$ & 16 & Sea & $3.6 \times 10^{4}$ & & & \\
\hline 5 & 6 & $1.8 \times 10^{5}$ & 16 & 10 & $1.0 \times 10^{2}$ & & & \\
\hline 5 & 7 & $8.0 \times 10^{2}$ & 16 & 12 & $1.1 \times 10^{5}$ & & & \\
\hline 5 & 8 & $1.0 \times 10^{3}$ & 16 & 15 & $5.6 \times 10^{4}$ & & & \\
\hline 6 & 3 & $7.6 \times 10^{4}$ & 16 & 17 & $3.6 \times 10^{4}$ & & & \\
\hline 6 & 4 & $4.8 \times 10^{3}$ & 16 & 18 & $1.2 \times 10^{5}$ & & & \\
\hline 6 & 5 & $9.8 \times 10^{4}$ & 17 & 12 & $4.4 \times 10^{4}$ & & & \\
\hline 6 & 8 & $2.7 \times 10^{4}$ & 17 & 15 & $5.5 \times 10^{4}$ & & & \\
\hline 6 & 18 & $1.5 \times 10^{3}$ & 17 & 16 & $6.0 \times 10^{4}$ & & & \\
\hline 7 & 5 & $8.0 \times 10^{2}$ & 17 & 19 & $3.6 \times 10^{5}$ & & & \\
\hline 7 & 8 & $1.8 \times 10^{4}$ & 18 & 3 & $7.2 \times 10^{4}$ & & & \\
\hline 7 & 9 & $9.0 \times 10^{2}$ & 18 & 6 & $2.0 \times 10^{4}$ & & & \\
\hline 8 & 5 & $4.0 \times 10^{2}$ & 18 & 8 & $9.4 \times 10^{3}$ & & & \\
\hline 8 & 6 & $9.2 \times 10^{3}$ & 18 & 10 & $7.7 \times 10^{4}$ & & & \\
\hline 8 & 7 & $1.8 \times 10^{4}$ & 18 & 16 & $9.2 \times 10^{4}$ & & & \\
\hline 8 & 18 & $2.4 \times 10^{4}$ & 18 & 19 & $7.9 \times 10^{4}$ & & & \\
\hline 8 & 19 & $4.2 \times 10^{3}$ & 19 & 4 & $5.9 \times 10^{4}$ & & & \\
\hline 9 & 7 & $9.0 \times 10^{2}$ & 19 & 10 & $8.7 \times 10^{4}$ & & & \\
\hline
\end{tabular}




\subsubsection{Compartmental Model of Nielsen et al. (1995)}

Nielsen et al. (1995) developed a multi-compartment model to simulate the movement of radionuclides released into the Arctic seas from dumpsites in the Kara Sea. The basic mass-balance equations for simulating radionuclide transport are similar to ones used in the RAIG model. The model developed by Niclsen et al. (1995) includes compartments that encompass all of the world's oceans. Water flows between compartments are calculated using a three-dimensional ocean circulation model (Chartier, 1993). Figurc 3-5 depicts the spatial arrangement of the surface or upper compartments for the Arctic Ocean, which represent generally the Arctic seas that form the Arctic Ocean. The most notable difference in the compartmental configuration of the RAIG model is that it includes a more refined treatment of the shelf areas along the Russian coastline, more compartments representing the Bering Sea adjacent to Alaska, and larger compartments for the central portion of the Arctic Ocean.

Because the primary focus of the RAIG is assessing the impacts that radionuclide releases could have on Alaskan waters, the team has implemented a modified version of the Nielsen et al. model that retains the compartmental structure shown in Figure 3-5, but consolidates the compartments representing the Atlantic Ocean and related seas into a single ocean compartment (denoted AORS) that is connected to the other world oceans (compartment 59). Recirculation to the Arctic Ocean occurs via transport through the Atlantic Ocean and related seas, the other world oceans, and then the Bering Strait. The modified compartmental configuration is shown in Figure 3-6. The

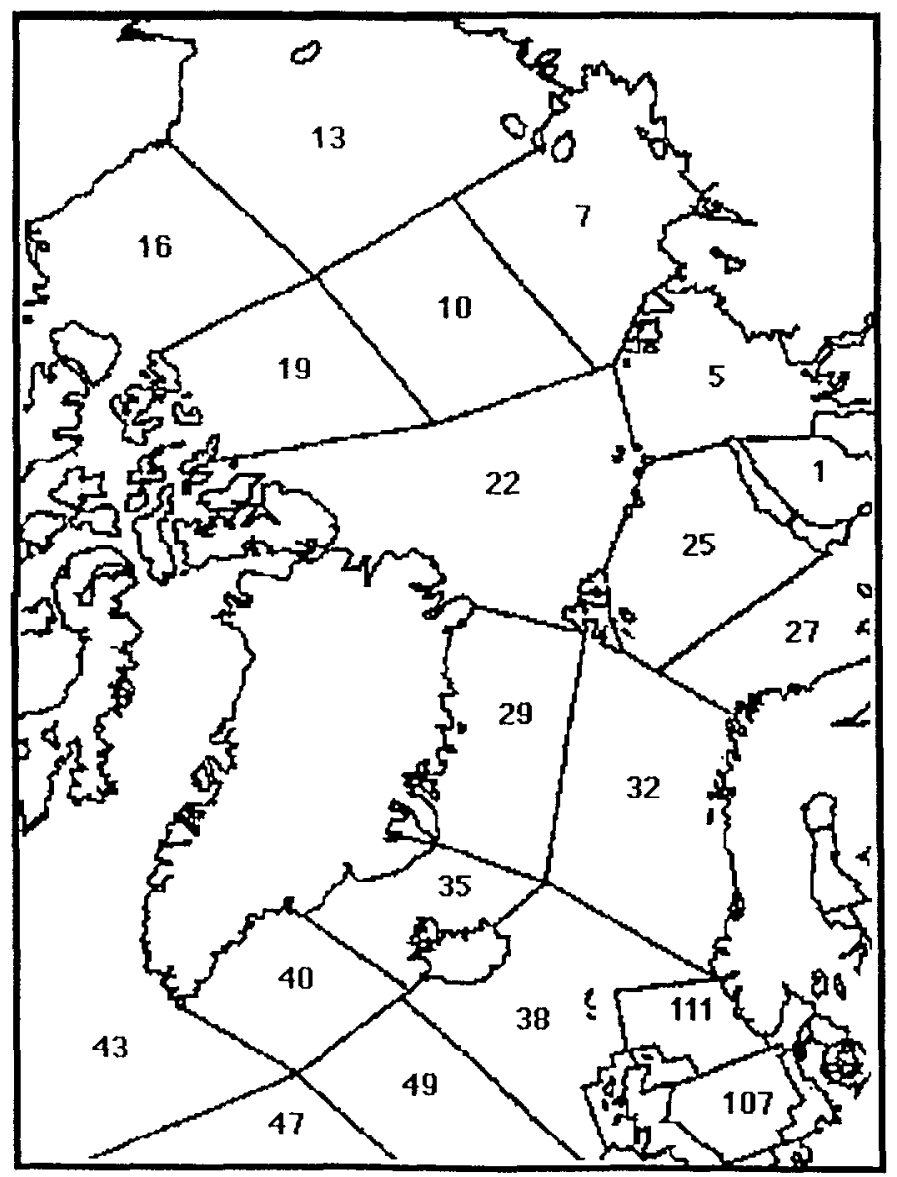

Figure 3-5. Locations of the surface-ocean compartments used in the Nielsen et al. (1995) model. 


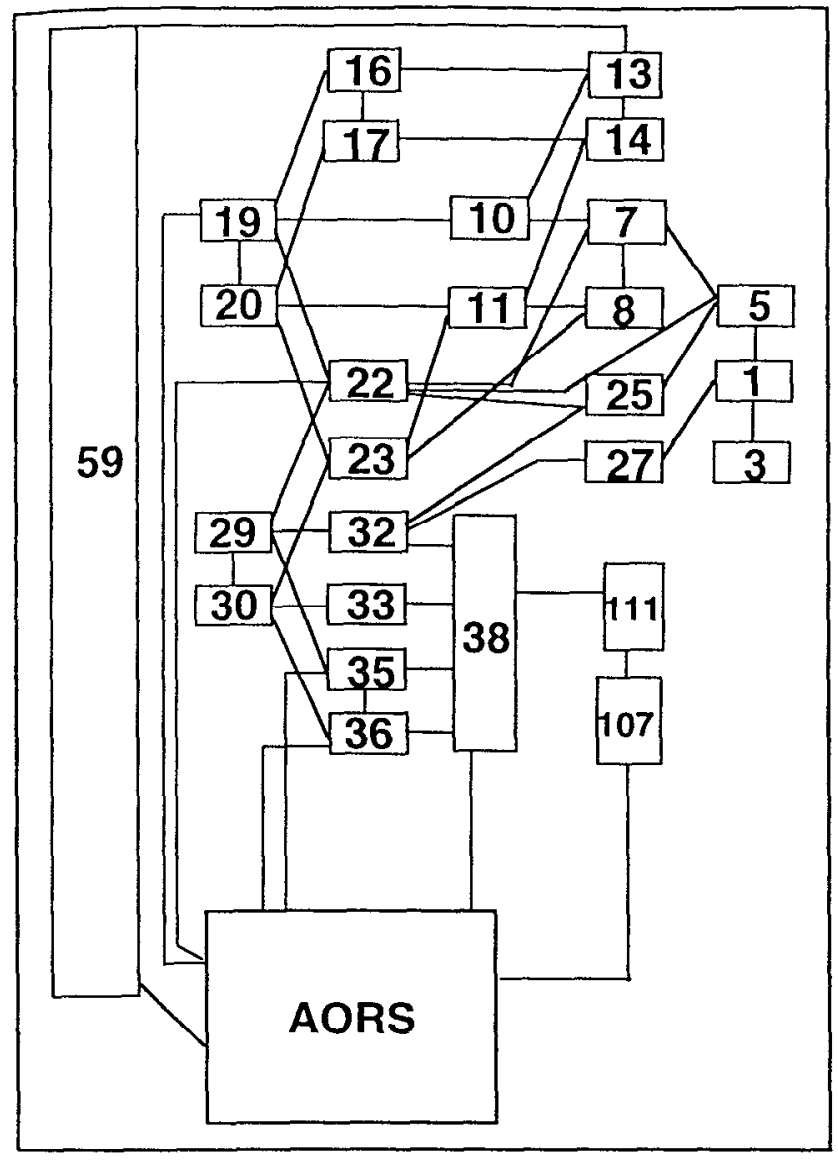

Figure 3-6. Modification of the compartmental structure used in Nielsen et al. (1995). The principal change is the consolidation of compartments representing the Atlantic Ocean and related seas into one compartment, denoted AORS.

RAIG also has assumed that particle resuspension over the assessment domain is far less important than particle scavenging, and therefore treats sediments as a sink or reservoir, with no transfers via pore-water diffusion or resuspension to overlying water columns. Table 3-4 presents the compartmental volumes, sediment loadings, and sedimentation rates used for each compartment. Volumetric exchanges between compartments are given in Table 3-5.

\subsubsection{Model Intercomparisons and Sensitivities}

To explore some of the uncertainties associated with the various source terms as well as the transport models, the RAIG will use the two CMs to simulate the alternative release scenarios. Both models were implemented in STELLA II. The simulations presented in this report were obtained using the 4th order Runge-Kutta option with a fixed time step of 0.1 year. In order to gain confidence that the STELLA II software was being used properly, the governing equations were also solved numerically using an ordinary differential equation solver with an adaptive time step. The adaptive method allows the time step to be increased or decreased according to the numerical behavior of the solution, thus allowing for an efficient use of the computer resource. It was determined that the two methods give essentially identical results for a step size of 0.1 ycar.

Tables 3-6 and 3-7 present simulations of $1 \mathrm{TBq}$ instantaneous releases of ${ }^{241} \Lambda \mathrm{m},{ }^{137} \mathrm{Cs}$, and ${ }^{239} \mathrm{Pu}$ to the Kara Sea and the Kara Sea estuary using the RAIG and modified Nielsen et al. models. For these particular simulations the R $\Lambda$ IG used the IAEA-recommended $K_{d} s$ for the three nuclides in 
both models (IAEA, 1995). The simulations of ${ }^{137} \mathrm{Cs}$ transport by the two models result in predicted concentrations for the Beaufort and Chukchi Seas that are quite comparable (concentrations are within a factor of 3 ).

Table 3-4. Data on compartment volumes, depths, sediment loadings, and sediment deposition for the modified Nielsen et al. (1995) compartmental model.

\begin{tabular}{|c|c|c|c|c|c|}
\hline Region & $\begin{array}{l}\text { Box } \\
\text { Id }\end{array}$ & $\begin{array}{c}\text { Volume } \\
\mathrm{m}^{3}\end{array}$ & $\begin{array}{l}\text { Depth } \\
\text { m }\end{array}$ & $\begin{array}{l}\mathrm{SSL} \\
\mathrm{t} / \mathrm{m}^{3}\end{array}$ & $\begin{array}{c}\text { SR } \\
t / m^{2}-y\end{array}$ \\
\hline Western Kara Sea & 1 & $1.2 \times 10^{13}$ & $7.0 \times 10^{1}$ & $3 \times 10^{-6}$ & $1 \times 10^{-3}$ \\
\hline Western Kara Sea deep & 3 & $1.6 \times 10^{13}$ & $2.5 \times 10^{2}$ & $6 \times 10^{-6}$ & $3 \times 10^{-4}$ \\
\hline Eastern Kara Sea & 5 & $7.0 \times 10^{13}$ & $7.0 \times 10^{1}$ & $3 \times 10^{-6}$ & $1 \times 10^{-3}$ \\
\hline Laptev Sea, upper & 7 & $2.2 \times 10^{14}$ & $3.3 \times 10^{2}$ & $1 \times 10^{-6}$ & $1 \times 10^{-4}$ \\
\hline Laptev Sea, lower & 8 & $4.8 \times 10^{14}$ & $7.0 \times 10^{2}$ & $1 \times 10^{-6}$ & $2 \times 10^{-5}$ \\
\hline Eurasian Basin, upper & 10 & $2.7 \times 10^{14}$ & $3.3 \times 10^{2}$ & $1 \times 10^{-6}$ & $1 \times 10^{-4}$ \\
\hline Eurasian Bain, lower & 11 & $2.7 \times 10^{15}$ & $3.2 \times 10^{3}$ & $1 \times 10^{-6}$ & $2 \times 10^{-5}$ \\
\hline East Siberian Sea, upper & 13 & $3.6 \times 10^{14}$ & $3.3 \times 10^{2}$ & $1 \times 10^{-6}$ & $1 \times 10^{-4}$ \\
\hline East Siberian Sea, lower & 14 & $9.9 \times 10^{14}$ & $9.0 \times 10^{2}$ & $1 \times 10^{-6}$ & $2 \times 10^{-5}$ \\
\hline Beaufort Sea, upper & 16 & $2.6 \times 10^{14}$ & $3.3 \times 10^{2}$ & $1 \times 10^{-6}$ & $1 \times 10^{-4}$ \\
\hline Beaufort Sea, lower & 17 & $8.8 \times 10^{14}$ & $1.2 \times 10^{3}$ & $1 \times 10^{-6}$ & $2 \times 10^{-5}$ \\
\hline Canadian Arctic Sca, upper & 19 & $2.1 \times 10^{14}$ & $3.3 \times 10^{2}$ & $1 \times 10^{-6}$ & $1 \times 10^{-4}$ \\
\hline Canadian Arctic Sea, lower & 20 & $2.1 \times 10^{14}$ & $2.2 \times 10^{3}$ & $1 \times 10^{-6}$ & $2 \times 10^{-5}$ \\
\hline Makarov and Fram Basin, upper & 22 & $4.7 \times 10^{14}$ & $3.3 \times 10^{2}$ & $1 \times 10^{-6}$ & $1 \times 10^{-4}$ \\
\hline Makarov and Fram Basins, lower & 23 & $4.1 \times 10^{15}$ & $2.9 \times 10^{3}$ & $1 \times 10^{-6}$ & $2 \times 10^{-5}$ \\
\hline Barents Sea North & 25 & $1.6 \times 10^{14}$ & $2.0 \times 10^{2}$ & $6 \times 10^{-6}$ & $5 \times 10^{-4}$ \\
\hline Barents Sea South & 27 & $1.6 \times 10^{14}$ & $2.0 \times 10^{2}$ & $6 \times 10^{-6}$ & $1 \times 10^{-3}$ \\
\hline Greenland Sea, upper & 29 & $2.5 \times 10^{14}$ & $3.3 \times 10^{2}$ & $1 \times 10^{-6}$ & $1 \times 10^{-4}$ \\
\hline Greenland Sea, lower & 30 & $1.4 \times 10^{15}$ & $1.8 \times 10^{3}$ & $1 \times 10^{-6}$ & $2 \times 10^{-5}$ \\
\hline Norwegian Sea, upper & 32 & $2.9 \times 10^{14}$ & $3.3 \times 10^{2}$ & $1 \times 10^{-6}$ & $1 \times 10^{-4}$ \\
\hline Norwegian Sea, lower & 33 & $1.7 \times 10^{15}$ & $1.9 \times 10^{2}$ & $1 \times 10^{-6}$ & $2 \times 10^{-5}$ \\
\hline Denmark Strait, upper & 35 & $1.3 \times 10^{14}$ & $3.3 \times 10^{2}$ & $1 \times 10^{-6}$ & $1 \times 10^{-4}$ \\
\hline Denmark Strait, lower & 36 & $8.0 \times 10^{13}$ & $2.0 \times 10^{2}$ & $1 \times 10^{-6}$ & $2 \times 10^{-5}$ \\
\hline Faroe Channel & 38 & $1.9 \times 10^{15}$ & $1.4 \times 10^{3}$ & $1 \times 10^{-6}$ & $1 \times 10^{-4}$ \\
\hline $\begin{array}{l}\text { North Sea Channel and } \\
\text { North Sea North }\end{array}$ & $\begin{array}{l}111 \text { and } \\
107\end{array}$ & $1.1 \times 10^{14}$ & $1.0 \times 10^{2}$ & $6 \times 10^{-6}$ & $1 \times 10^{-4}$ \\
\hline Atlantic Ocean and related seas & AORS & $1.5 \times 10^{17}$ & $3.8 \times 10^{3}$ & $1 \times 10^{-6}$ & $2 \times 10^{-5}$ \\
\hline Other world oceans & 59 & $1.1 \times 10^{18}$ & $3.8 \times 10^{3}$ & $1 \times 10^{-6}$ & $2 \times 10^{-5}$ \\
\hline
\end{tabular}

The largest differences between the models are for the predicted levels of ${ }^{241} \mathrm{Am}$ and ${ }^{239} \mathrm{Pu}$ in the two seas after an instantaneous release to the Kara Sea. Both of these nuclides are more particle reactive than ${ }^{137} \mathrm{Cs}$, and consequently they are more effectively scavenged from the water column. The Kara Sea compartment of the modified Nielsen et al. model (see Figure 3-5) does not discharge directly to the central Arctic Ocean, as does the RAIG model, and therefore there is likely to be more depletion by particle scavenging in the coastal compartments ( 1 and 5). 
Table 3-5. Volumetric exchange of water between compartments of the modified Nielsen et al. (1995) compartmental model. Note that some exchanges do not balance because of roundoff error.

\begin{tabular}{|c|c|c|c|c|c|c|c|c|}
\hline $\begin{array}{c}\text { From } \\
\text { Box }\end{array}$ & $\begin{array}{c}\text { To } \\
\text { Box } \\
\end{array}$ & $\begin{array}{c}\text { Flux } \\
\left(\mathrm{km}^{3} \mathrm{y}^{-1}\right)\end{array}$ & $\begin{array}{c}\text { From } \\
\text { Box }\end{array}$ & $\begin{array}{c}\text { To } \\
\text { Box }\end{array}$ & $\begin{array}{c}\begin{array}{c}\text { Flux } \\
\left(\mathrm{km}^{3} \mathrm{y}^{-1}\right)\end{array} \\
\end{array}$ & $\begin{array}{c}\text { From } \\
\text { Box }\end{array}$ & $\begin{array}{l}\text { To } \\
\text { Box }\end{array}$ & $\begin{array}{c}\begin{array}{c}\text { Flux } \\
\left(\mathrm{km}^{3} \mathrm{y}^{-1}\right)\end{array} \\
\end{array}$ \\
\hline 1 & 3 & $3.2 \times 10^{3}$ & 20 & 23 & $8.0 \times 10^{4}$ & 35 & AORS & $1.6 \times 10^{5}$ \\
\hline 1 & 5 & $9.5 \times 10^{2}$ & 22 & 7 & $6.5 \times 10^{4}$ & 36 & 35 & $2.8 \times 10^{4}$ \\
\hline 1 & 27 & $9.5 \times 10^{2}$ & 22 & 10 & $4.7 \times 10^{4}$ & 36 & 38 & $2.8 \times 10^{4}$ \\
\hline 3 & 1 & $3.2 \times 10^{3}$ & 22 & 19 & $2.5 \times 10^{4}$ & 36 & AORS & $4.5 \times 10^{5}$ \\
\hline 5 & 1 & $9.5 \times 10^{2}$ & 22 & 23 & $3.2 \times 10^{4}$ & 38 & 32 & $3.0 \times 10^{5}$ \\
\hline 5 & 7 & $8.5 \times 10^{3}$ & 22 & 25 & $1.6 \times 10^{4}$ & 38 & 33 & $1.5 \times 10^{5}$ \\
\hline 5 & 22 & $5.2 \times 10^{4}$ & 22 & 29 & $9.1 \times 10^{4}$ & 38 & 35 & $2.3 \times 10^{4}$ \\
\hline 5 & 25 & $9.5 \times 10^{3}$ & 22 & 43 & $1.4 \times 10^{4}$ & 38 & 36 & $1.5 \times 10^{5}$ \\
\hline 7 & 8 & $3.7 \times 10^{4}$ & 23 & 8 & $6.0 \times 10^{4}$ & 38 & AORS & $2.1 \times 10^{5}$ \\
\hline 7 & 10 & $6.9 \times 10^{4}$ & 23 & 11 & $6.9 \times 10^{4}$ & 38 & AORS & $2.6 \times 10^{5}$ \\
\hline 7 & 22 & $1.8 \times 10^{4}$ & 23 & 20 & $4.0 \times 10^{4}$ & 38 & 61 & $8.3 \times 10^{3}$ \\
\hline 8 & 7 & $2.1 \times 10^{4}$ & 23 & 22 & $4.6 \times 10^{4}$ & 38 & $111 / 107$ & $3.4 \times 10^{4}$ \\
\hline 8 & 11 & $1.3 \times 10^{5}$ & 23 & 30 & $1.2 \times 10^{4}$ & 40 & 35 & $1.7 \times 10^{5}$ \\
\hline 10 & 7 & $2.9 \times 10^{4}$ & 25 & 5 & $6.9 \times 10^{4}$ & 40 & 38 & $1.4 \times 10^{5}$ \\
\hline 10 & 11 & $3.3 \times 10^{4}$ & 25 & 22 & $8.5 \times 10^{3}$ & 59 & 13 & $2.8 \times 10^{4}$ \\
\hline 10 & 13 & $2.8 \times 10^{3}$ & 25 & 27 & $9.5 \times 10^{3}$ & 59 & AORS & $1.6 \times 10^{6}$ \\
\hline 10 & 19 & $1.6 \times 10^{5}$ & 25 & 32 & $1.9 \times 10^{4}$ & $111 / 107$ & 38 & $5.0 \times 10^{4}$ \\
\hline 10 & 22 & $1.0 \times 10^{5}$ & 27 & 1 & $9.5 \times 10^{2}$ & AOR & 59 & $1.7 \times 10^{6}$ \\
\hline 11 & 8 & $5.5 \times 10^{4}$ & 27 & 25 & $7.7 \times 10^{4}$ & & & \\
\hline 11 & 10 & $2.2 \times 10^{4}$ & 27 & 32 & $3.2 \times 10^{4}$ & & & \\
\hline 11 & 20 & $8.8 \times 10^{4}$ & 29 & 22 & $4.7 \times 10^{4}$ & & & \\
\hline 11 & 23 & $1.1 \times 10^{5}$ & 29 & 30 & $9.2 \times 10^{4}$ & & & \\
\hline 13 & 10 & $1.9 \times 10^{5}$ & 29 & 32 & $2.0 \times 10^{4}$ & & & \\
\hline 13 & 14 & $1.4 \times 10^{5}$ & 29 & 35 & $1.9 \times 10^{5}$ & & & \\
\hline 14 & 11 & $4.6 \times 10^{4}$ & 30 & 23 & $2.2 \times 10^{3}$ & & & \\
\hline 14 & 13 & $1.4 \times 10^{5}$ & 30 & 29 & $3.0 \times 10^{4}$ & & & \\
\hline 16 & 13 & $1.5 \times 10^{5}$ & 30 & 33 & $6.1 \times 10^{4}$ & & & \\
\hline 16 & 17 & $4.5 \times 10^{4}$ & 30 & 36 & $1.4 \times 10^{5}$ & & & \\
\hline 16 & 19 & $4.7 \times 10^{3}$ & 32 & 25 & $4.4 \times 10^{3}$ & & & \\
\hline 17 & 14 & $4.7 \times 10^{4}$ & 32 & 27 & $9.9 \times 10^{4}$ & & & \\
\hline 17 & 16 & $5.6 \times 10^{4}$ & 32 & 29 & $2.3 \times 10^{5}$ & & & \\
\hline 17 & 20 & $1.5 \times 10^{4}$ & 32 & 3.3 & $7.4 \times 10^{4}$ & & & \\
\hline 19 & 16 & $1.5 \times 10^{5}$ & 32 & 38 & $6.3 \times 10^{3}$ & & & \\
\hline 19 & 20 & $3.2 \times 10^{4}$ & 33 & 30 & $1.3 \times 10^{5}$ & & & \\
\hline 19 & 22 & $1.8 \times 10^{4}$ & 33 & 32 & $4.6 \times 10^{4}$ & & & \\
\hline 19 & 43 & $1.4 \times 10^{4}$ & 33 & 38 & $1.1 \times 10^{5}$ & & & \\
\hline 20 & 17 & $7.4 \times 10^{4}$ & 35 & 36 & $1.9 \times 10^{5}$ & & & \\
\hline 20 & 19 & $2.2 \times 10^{4}$ & 35 & 38 & $7.4 \times 10^{4}$ & & & \\
\hline
\end{tabular}


Table 3-6. Predicted concentrations of ${ }^{241} \mathrm{Am},{ }^{137} \mathrm{Cs}$, and ${ }^{239} \mathrm{Pu}$ in the Beaufort and Chukchi seas after an instantaneous release of $1 \mathrm{TBq}$ of each radionuclide in the Kara Sea.

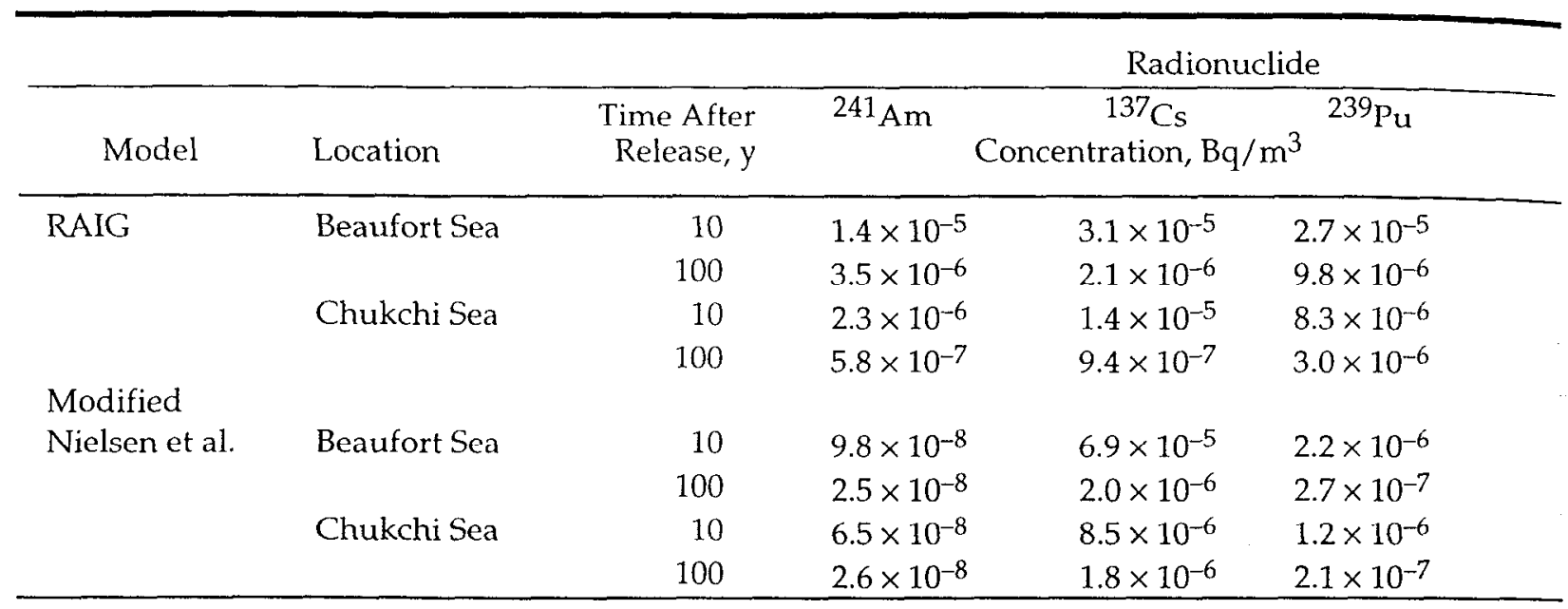

The result is accentuated for ${ }^{241} \mathrm{Am}$ because the IAEA $\mathrm{K}_{d}$ used in the simulation is a factor of 10 greater than the one for ${ }^{239} \mathrm{Pu}$ and hence there is more particle scavenging for this nuclide. To further explore the importance of particle scavenging in the concentrations predicted by the RAIG model, the RAIG ran two cases using ${ }^{239} \mathrm{Pu}$, one with a $\mathrm{K}_{\mathrm{d}}$ of $100 \mathrm{~m}^{3} / \mathrm{kg}$ (or $10^{5}$ unitless) and the other with its $K_{d}$ set equal to zero. Without particle scavenging (i.e., $K_{d}=0$ and the contaminant is completely in the water phase, with no sorption to suspended particles), the predicted concentrations in the Beaufort and Chukchi Seas after an instantaneous release in the Kara Sea were factors of 2 and 3 greater than with particle scavenging.

Table 3-7. Predicted concentrations of ${ }^{241} \mathrm{Am},{ }^{137} \mathrm{Cs}$, and ${ }^{239} \mathrm{Pu}$ in the Beaufort and Chukchi seas after an instantaneous discharge of $1 \mathrm{TBq}$ of each radionuclide to the Kara Sea estuary from the Ob or Yenisey rivers.

\begin{tabular}{lrrrrr}
\hline & & \multicolumn{4}{c}{ Radionuclide } \\
\hline \multirow{2}{*}{ Model } & Location & $\begin{array}{c}\text { Time After } \\
\text { Release, } \mathrm{y}\end{array}$ & ${ }^{241} \mathrm{Am}$ & \multicolumn{2}{c}{$137 \mathrm{Cs}$} \\
Concentration, Bq $/ \mathrm{m}^{3}$ & \\
\hline RAIG & Beaufort Sea & 10 & $1.9 \times 10^{-6}$ & $2.6 \times 10^{-5}$ & $9.9 \times 10^{-6}$ \\
& & 100 & $4.9 \times 10^{-7}$ & $2.0 \times 10^{-6}$ & $3.7 \times 10^{-6}$ \\
& Chukchi Sea & 10 & $3.2 \times 10^{-7}$ & $1.2 \times 10^{-5}$ & $3.1 \times 10^{-6}$ \\
Modified & 100 & $8.1 \times 10^{-8}$ & $8.9 \times 10^{-7}$ & $1.2 \times 10^{-6}$ \\
Nielsen et al. & Beaufort Sea & 10 & $1.2 \times 10^{-6}$ & $6.4 \times 10^{-5}$ & $1.2 \times 10^{-5}$ \\
& & 100 & $3.4 \times 10^{-7}$ & $2.2 \times 10^{-6}$ & $2.8 \times 10^{-6}$ \\
& Chukchi Sea & 10 & $1.0 \times 10^{-6}$ & $3.5 \times 10^{-5}$ & $8.2 \times 10^{-6}$ \\
& & 100 & $3.5 \times 10^{-7}$ & $1.9 \times 10^{-6}$ & $2.6 \times 10^{-6}$ \\
\hline
\end{tabular}


The primary differences between the two compartmental models that account for differences in the predicted concentrations of the radionuclide contaminants are the arrangement of the compartments and the flows of water between the compartments. As a first-order comparison of water flows, Table 3-8 presents the Arctic Ocean water balances associated with the RAIG and modified Nielsen et al. models as well as those based on current measurements and oceanographic tracers. The RAIG model results fall between the water exchange rates for the Nielsen et al. model and those based on oceanographic measurements.

Table 3-8. Comparison of water exchange rates for the Arctic Ocean.

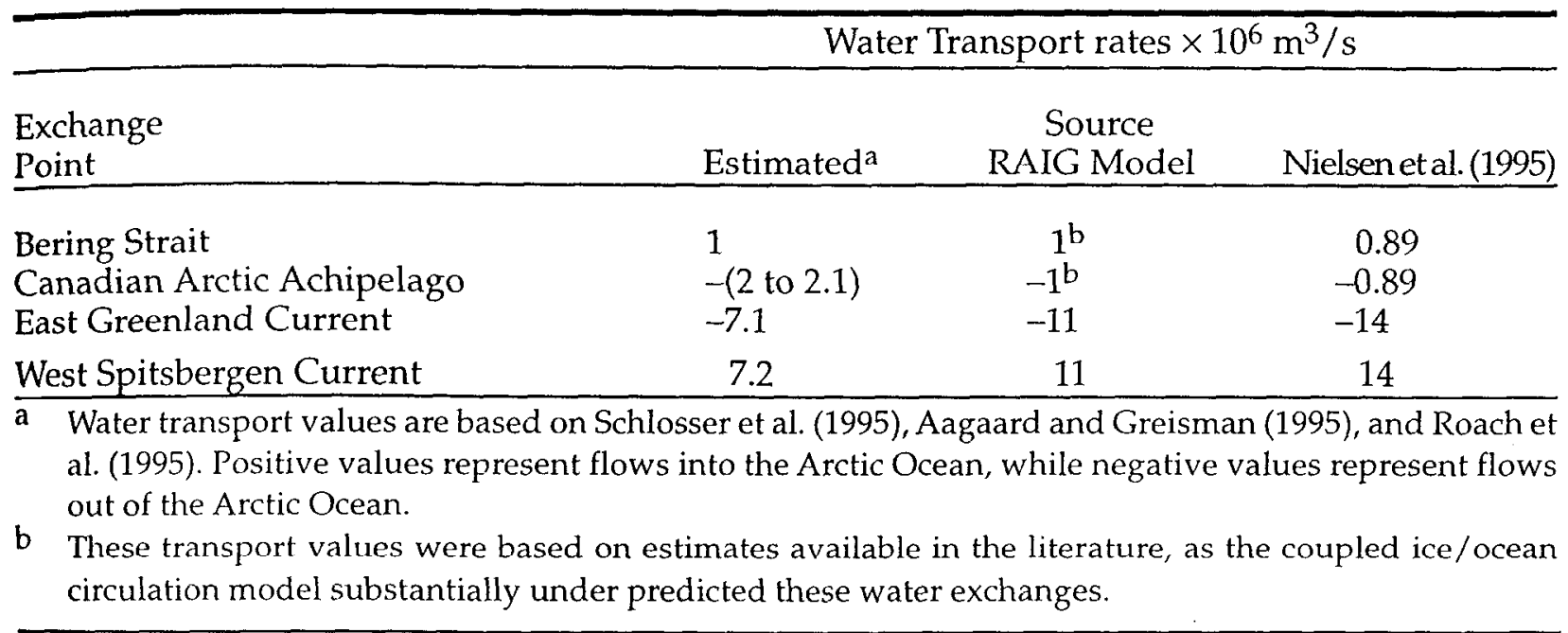

\subsubsection{Simulations of Radionuclide Release Scenarios}

The three sources of nuclear wastes this assessment addresses (i.e., the Kara Sea dumpsites, riverine releases from inland waste sites, and nuclear materials in the Northwest Pacific Ocean) have different inventories of the principal radionuclides and different release mechanisms. To bracket the range of potential releases, the RAIG will predict concentrations associated with the instantaneous release of the total estimated inventories presented in Section 2 as well as time-varying releases resulting from the leaching of radionuclides from waste matrices. An instantaneous release case is clearly a worst-case scenario for the Kara Sea dumpsites, as it is difficult to postulate a mechanism by which the radionuclides would suddenly be transferred from waste to water. A more likely release mechanism is the slow discharge to water via corrosion and degradation of waste materials containing the radioactive substances. Riverine releases, on the other hand, could very well be simulated as an instantaneous or pulse-type release, because one postulated release mechanism is retention dams' failure to hold back radioactive liquid wastes adjacent to tributaries of the $\mathrm{Ob}$ and Yenisey rivers. 


\section{Releases to the Kara Sea}

\section{Instantaneous Releases}

To facilitate comparisons of the release scenarios, the RAIG simulates the discharge of $1 \mathrm{TBq}\left(10^{12}\right.$ $\mathrm{Bq}$ ) of each of the radionuclides to the Kara Sea. For comparison, the estimated inventories as of 1994 (see Section 2) were 8.3, 6.2, 950, and 1,000 TBq for ${ }^{241} \mathrm{Am},{ }^{239} \mathrm{Pu}$, ${ }^{90} \mathrm{Sr}$, and ${ }^{137} \mathrm{Cs}$, respectively. Figure 3-7 depicts the time-varying concentration of ${ }^{137} \mathrm{Cs}$ in the Chukchi, Beaufort, and Bering Seas resulting from the release of $1 \mathrm{TBq}\left(\mathrm{K}_{\mathrm{d}}=0.3 \mathrm{~m}^{3} / \mathrm{kg}\right)$. The Beaufort Sea attains a higher peak concentration than the Chukchi Sea (about a factor of 2 higher), but both compartments reach the peak in about 11 to 12 years. Similar results were obtained for ${ }^{90} \mathrm{Sr}$, as both $\mathrm{Cs}$ and $\mathrm{Sr}$ behave almost identically (that is, as a conservative solute) for the $\mathrm{K}_{d} s$ presented in Table 3-1. The peak concentration for ${ }^{137} \mathrm{Cs}$ of about $3 \times 10^{-5} \mathrm{~Bq} / \mathrm{m}^{3}$ must be multiplied by 1,000 to obtain the estimated concentration associated with a release of the total inventory as of 1994 , or $0.03 \mathrm{~Bq} / \mathrm{m}^{3}$.

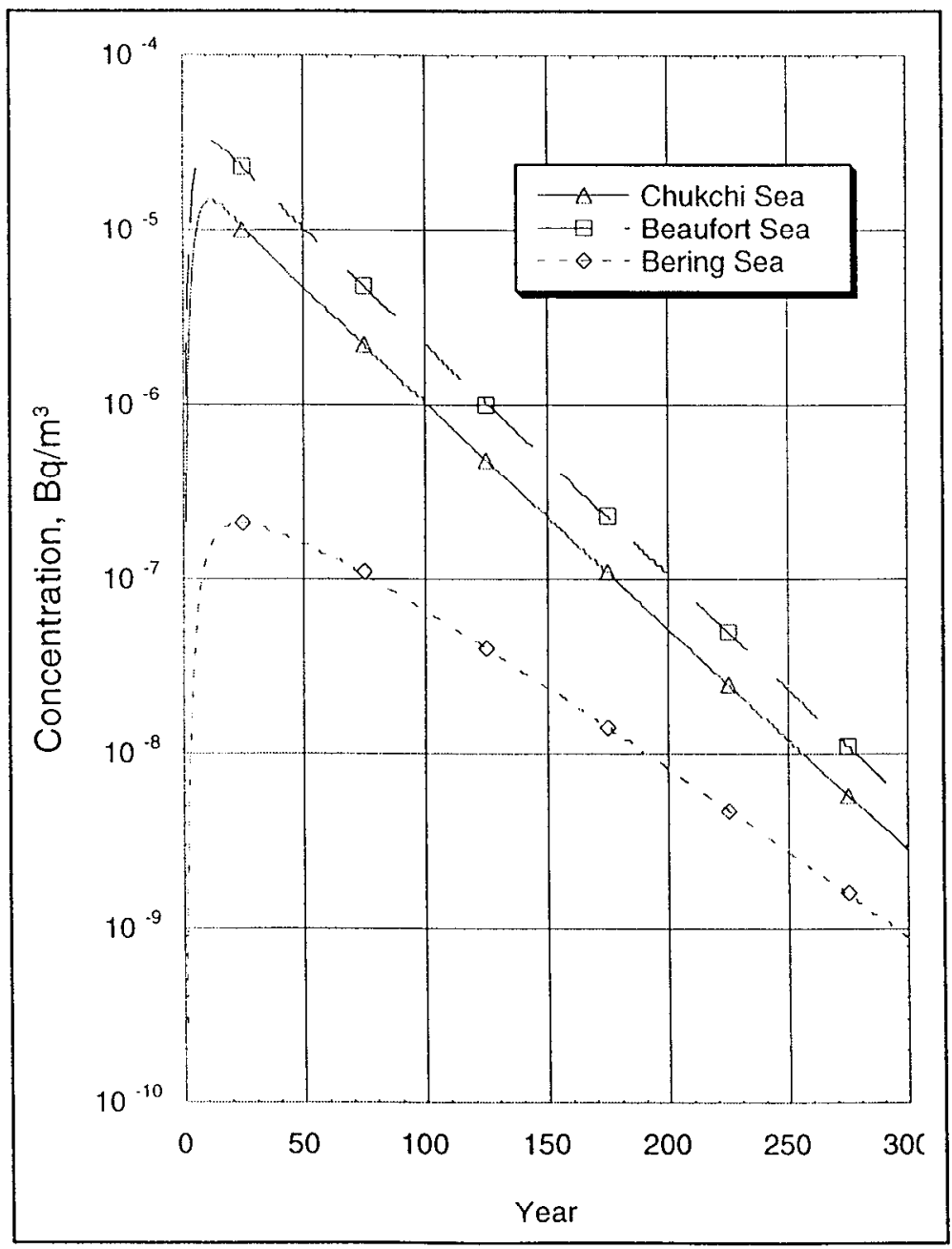

Figure 3-7. Concentrations of ${ }^{137} \mathrm{Cs}$ in the Chukchi, Beaufort, and Bering seas resulting from an instantaneous release of 1 TBq in the Kara Sea. 


\section{Time-Varying Releases}

Figures 3-8, 3-9, and 3-10 present the Chukchi, Beaufort, and Bering seas' four radionuclide concentrations resulting from the time-varying nuclide releases into the Kara Sea from the wastes dumped there (Figure 2-7 shows the release-rate changes as a function of time.) Initial releases begin in the year 2000 and peak about 50 years later. A secondary peak occurs around 2300 as a result of the failure of containers holding SNFs. The highest fission-products concentrations in the Beaufort and Chukchi seas occur in 2080; the highest in the Bering Sea occur about 20 years later because of the transport time lag. Actinide concentrations are highest after the waste containers fail. Table 3-9 presents the times at which the peak doses occur and the associated concentrations of the four nuclides at that time. Because the dose is dominated by ${ }^{137} \mathrm{Cs}$, the peak doses do not coincide with the times of the highest predicted actinide concentrations.

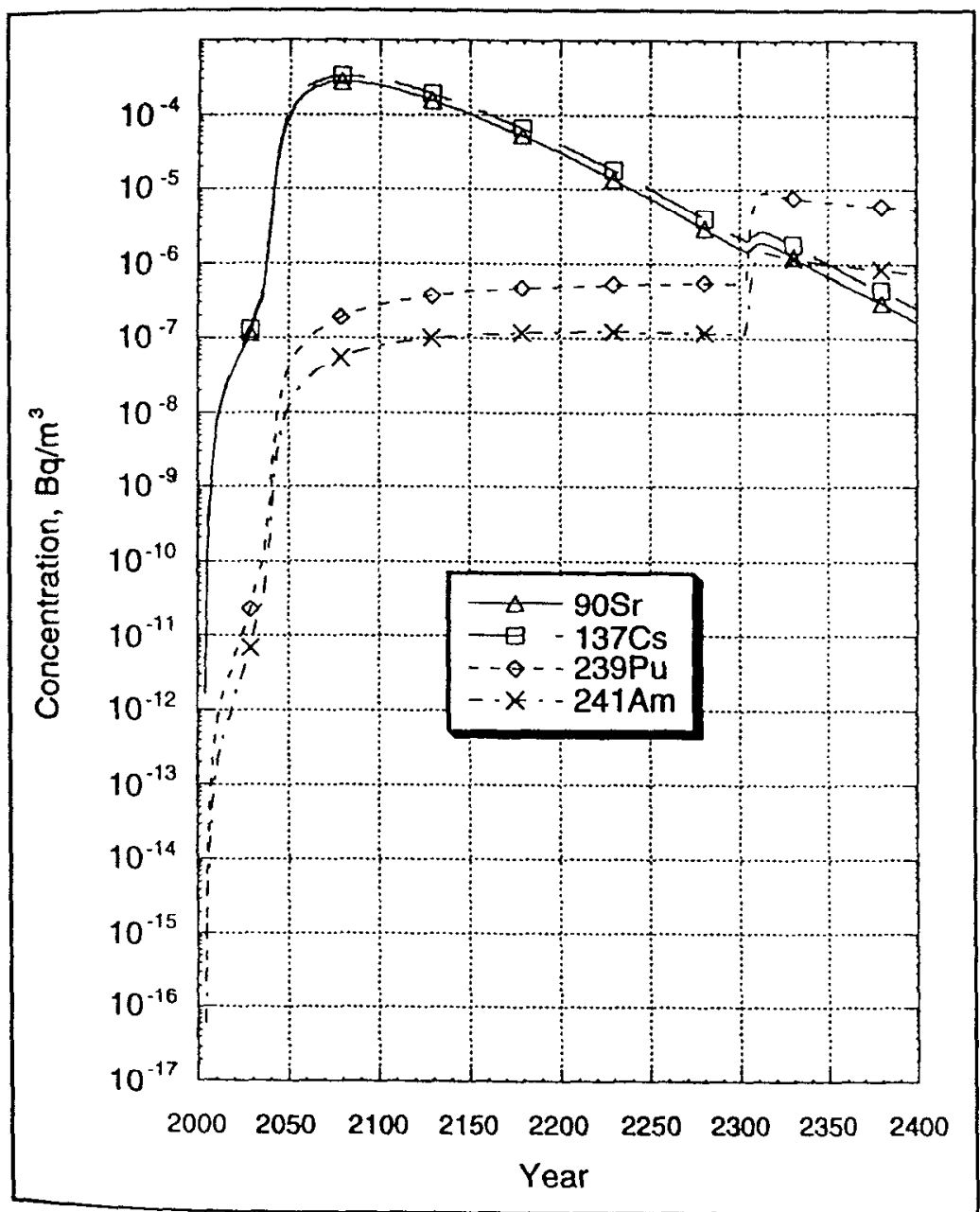

Figure 3-8. Concentrations of ${ }^{241} \mathrm{Am},{ }^{137} \mathrm{Cs}$, ${ }^{239} \mathrm{Pu}$, and ${ }^{90} \mathrm{Sr}$ in the Chukchi Sea resulting from the time-varying release of radionuclides from the Kara Sea nuclear wastes. 


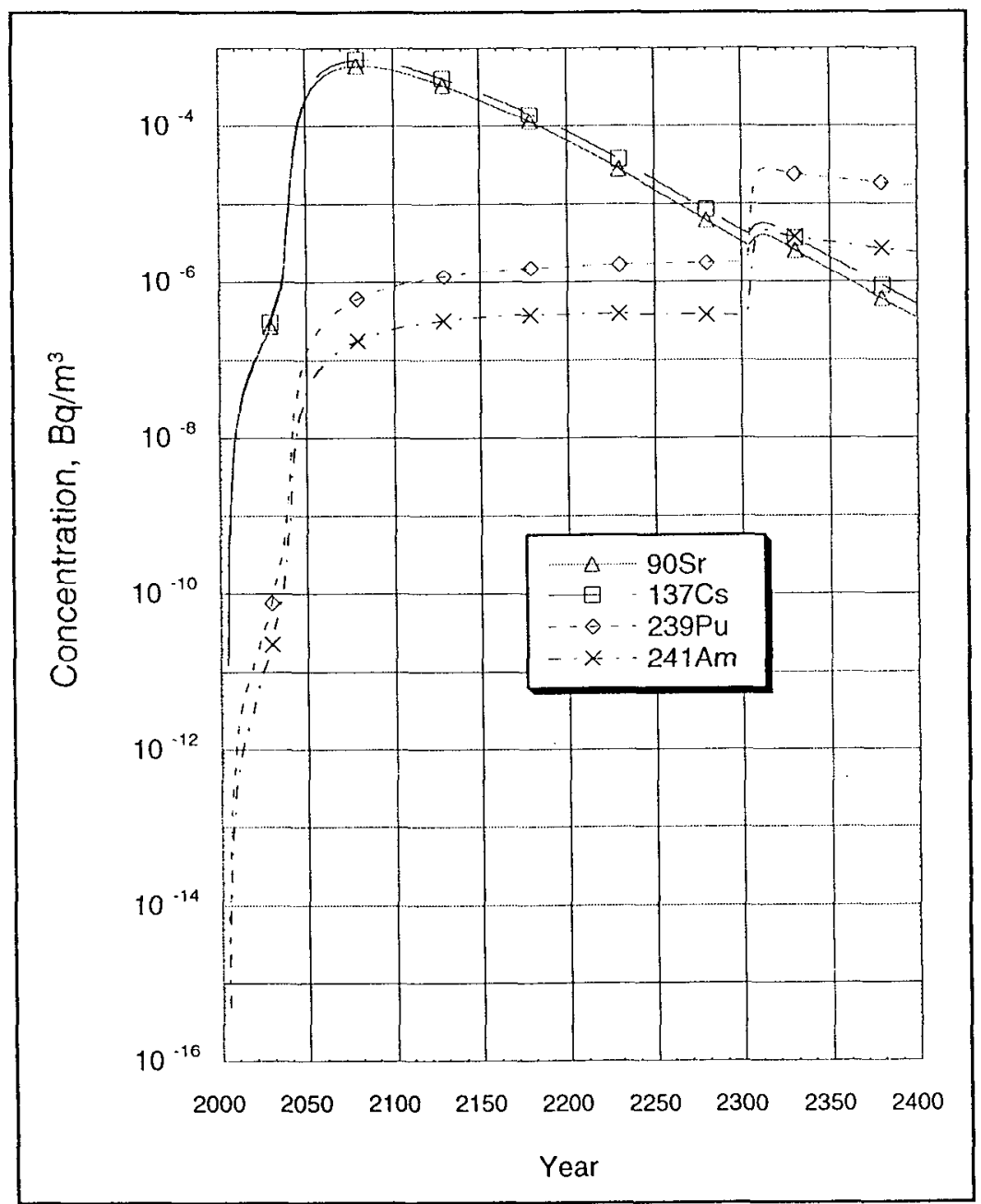

Figure 3-9. Concentrations of ${ }^{241} \mathrm{Am},{ }^{137} \mathrm{Cs},{ }^{239} \mathrm{Pu}$, and ${ }^{90} \mathrm{Sr}$ in the Beaufort Sea resulting from the time-varying release of radionuclides from the Kara Sea nuclear wastes. 


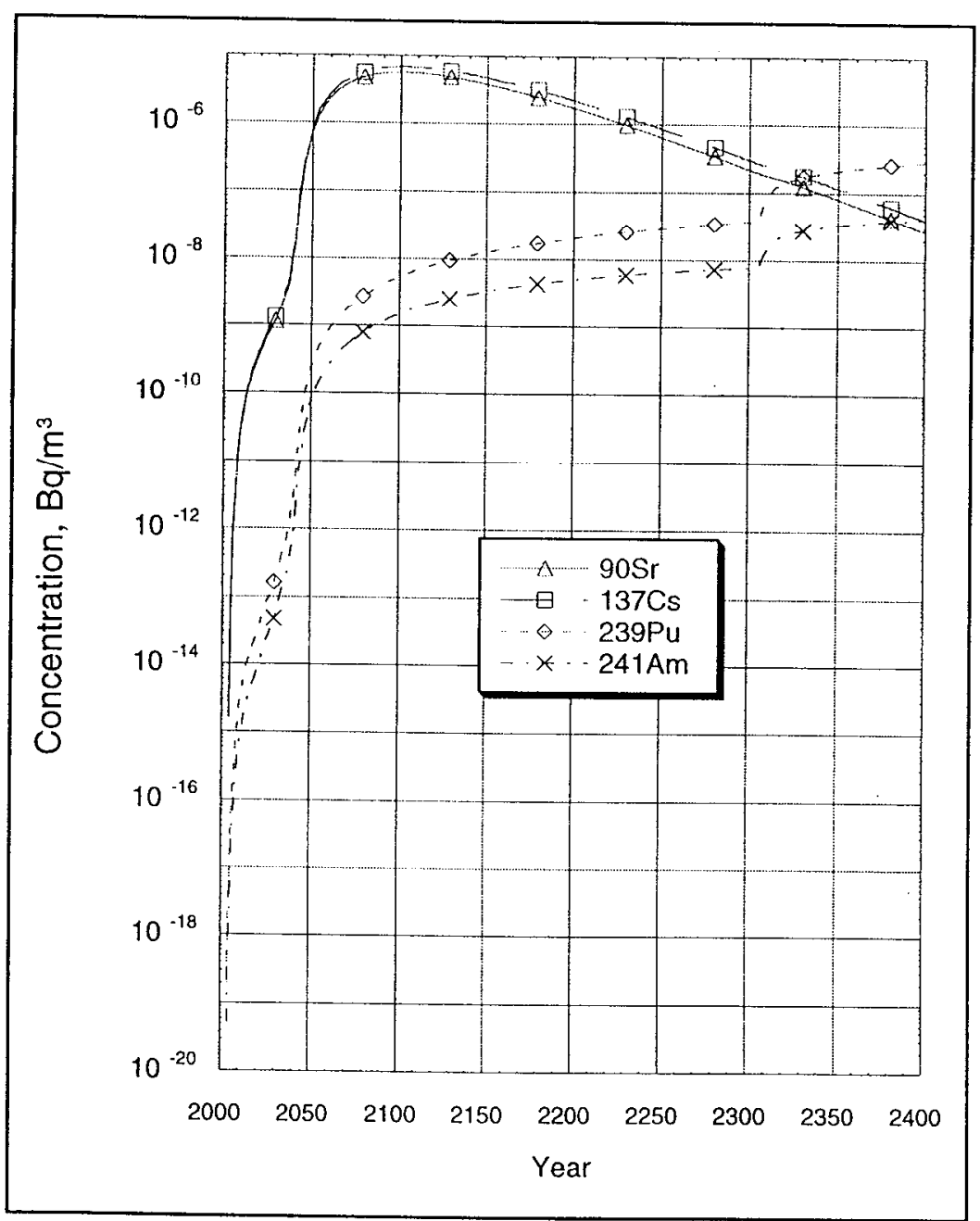

Figure 3-10. Concentrations of ${ }^{241} \mathrm{Am},{ }^{137} \mathrm{Cs},{ }^{239} \mathrm{Pu}$, and ${ }^{90} \mathrm{Sr}$ in the Bering Sea resulting from the time-varying release of radionuclides from the Kara Sea nuclear wastes. 
Table 3-9. Concentrations associated with peak doses resulting from different source-term scenarios.

\begin{tabular}{|c|c|c|c|c|c|}
\hline \multirow[b]{3}{*}{ Scenario/Location } & \multirow{3}{*}{$\begin{array}{l}\text { Time } \\
\text { of Pcak } \\
\text { Dose }\end{array}$} & \multicolumn{4}{|c|}{ Radionuclide } \\
\hline & & ${ }^{241} \mathrm{Am}$ & ${ }^{137} \mathrm{Cs}$ & ${ }^{239} \mathrm{Pr}$ & ${ }^{90} \mathrm{Sr}$ \\
\hline & & \multicolumn{4}{|c|}{ Concentration, $\mathrm{Bq} / \mathrm{m}^{3}$} \\
\hline \multirow{2}{*}{\multicolumn{6}{|c|}{ Instantaneous release to the Kara }} \\
\hline & \multicolumn{5}{|c|}{ Sea } \\
\hline Beaufort Sea & 12 & $2.2 \times 10^{-4}$ & $3.2 \times 10^{-2}$ & $1.6 \times 10^{-4}$ & $3.0 \times 10^{-2}$ \\
\hline Bering Sea & 25 & $9.5 \times 10^{-7}$ & $2.1 \times 10^{-4}$ & $7.4 \times 10^{-7}$ & $2.0 \times 10^{-4}$ \\
\hline Chukchi Sea & 12 & $6.8 \times 10^{-5}$ & $1.5 \times 10^{-2}$ & $5.2 \times 10^{-5}$ & $1.4 \times 10^{-2}$ \\
\hline \multicolumn{6}{|c|}{ Time-varying release to the Kara } \\
\hline \multicolumn{6}{|c|}{ Sea } \\
\hline Beaufort Sea & 2,080 & $1.8 \times 10^{-7}$ & $7.1 \times 10^{-4}$ & $6.4 \times 10^{-7}$ & $6.0 \times 10^{-4}$ \\
\hline Bering Sea & 2,100 & $1.5 \times 10^{-9}$ & $6.8 \times 10^{-6}$ & $5.3 \times 10^{-9}$ & $5.6 \times 10^{-6}$ \\
\hline Chukchi Sea & 2,080 & $5.6 \times 10^{-8}$ & $3.2 \times 10^{-4}$ & $2.0 \times 10^{-7}$ & $2.7 \times 10^{-4}$ \\
\hline \multicolumn{6}{|c|}{$\begin{array}{l}\text { Accidental release to the Ob River } \\
\text { from Mayak }\end{array}$} \\
\hline Beaufort Sea & 14 & & $7.9 \times 10^{-4}$ & & $4.6 \times 10^{-2}$ \\
\hline Bering Sea & 25 & & $4.1 \times 10^{-6}$ & & $3.0 \times 10^{-4}$ \\
\hline Chukchi Sea & 14 & & $3.6 \times 10^{-4}$ & & $2.1 \times 10^{-2}$ \\
\hline \multicolumn{6}{|c|}{$\begin{array}{l}\text { Chronic release to the Kara Sea } \\
\text { from the } \mathrm{Ob} \text { and Yenisey rivers }\end{array}$} \\
\hline Beaufort Sea & 45 & & & & $2.1 \times 10^{-2}$ \\
\hline Bering Sea & 70 & & & & $2.0 \times 10^{-4}$ \\
\hline Chukchi Sea & 45 & & & & $9.4 \times 10^{-3}$ \\
\hline
\end{tabular}

aThe time of the peak dose refers to the number of years after a release occurs, except in the case of the time-varying release from the Kara Sea sources where the time of the peak is the year in which it occurs. 


\section{Releases from the $\mathrm{Ob}$ and Yenisey Rivers}

\section{Acute Releases}

The acute release scenarios for radionuclide discharges to the $\mathrm{Ob}$ and Yenisey rivers consist of the year-long discharge of $1.4 \mathrm{PBq}$ of ${ }^{90} \mathrm{Sr}$ and $24 \mathrm{TBq}$ of ${ }^{137} \mathrm{Cs}$, respectively, from the hypothesized failure of liquid-waste reservoirs at Mayak (see Section 2). Figures 3-11 and 3-12 show the resulting concentrations in the Chukchi, Beaufort, and Bering Seas for ${ }^{90} \mathrm{Sr}$ and ${ }^{137} \mathrm{Cs}$, respectively. The peak concentrations of ${ }^{137} \mathrm{Cs}$ associated with the acute riverine releases, as summarized in Table 3-9, are comparable to the peak levels predicted for the time-varying release to the Kara Sea from the spent nuclear fuels. However, the predicted peak levels for ${ }^{90} \mathrm{Sr}$ are more consistent with the instantaneous release to the Kara Sea because it is comparable in magnitude (i.e., $\sim 1 \mathrm{PBq}$ ).

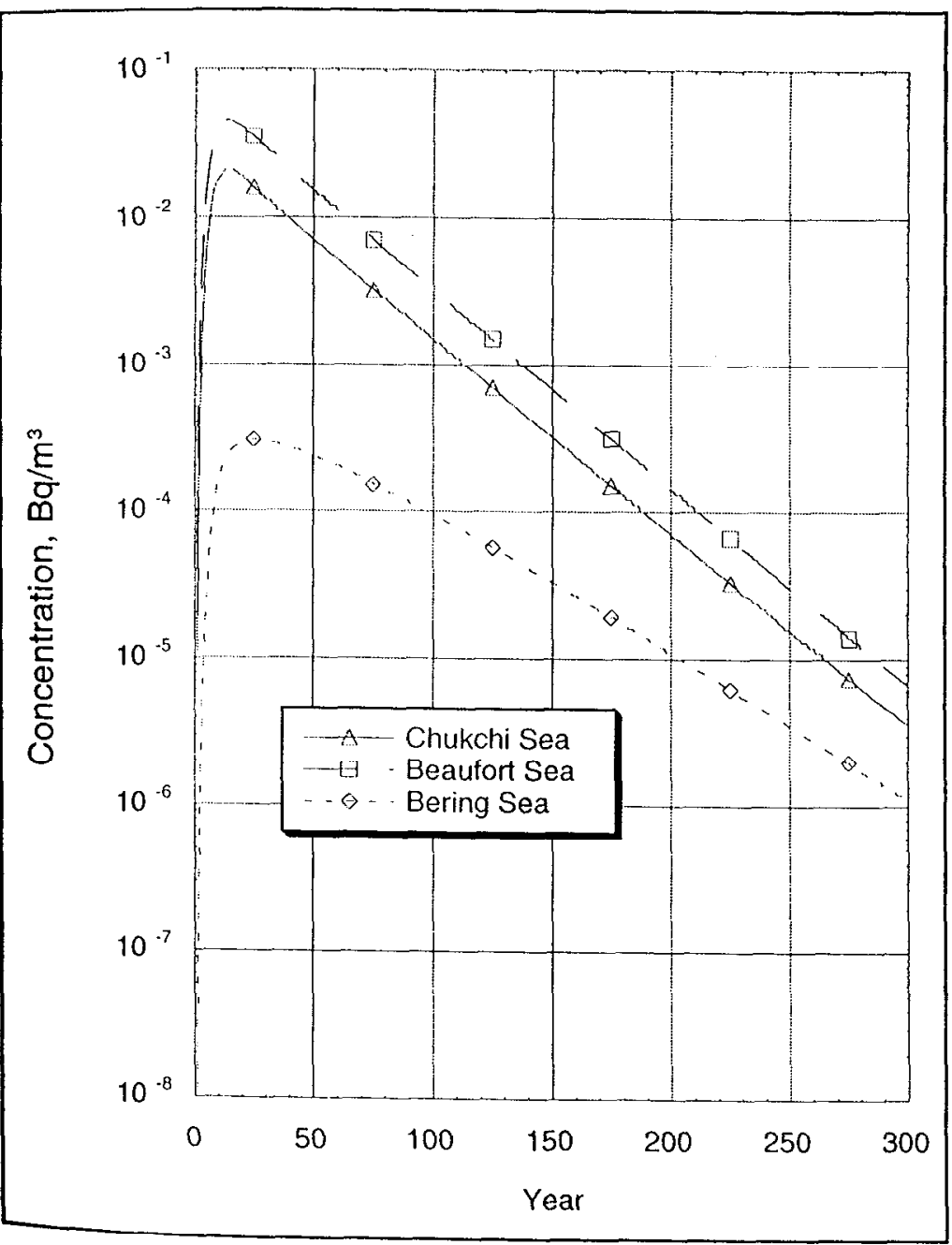

Figure 3-11. Concentrations of ${ }^{90} \mathrm{Sr}$ in the Beaufort, Bering, and Chukchi seas resulting from the accidental release of liquid waste from Mayak. 


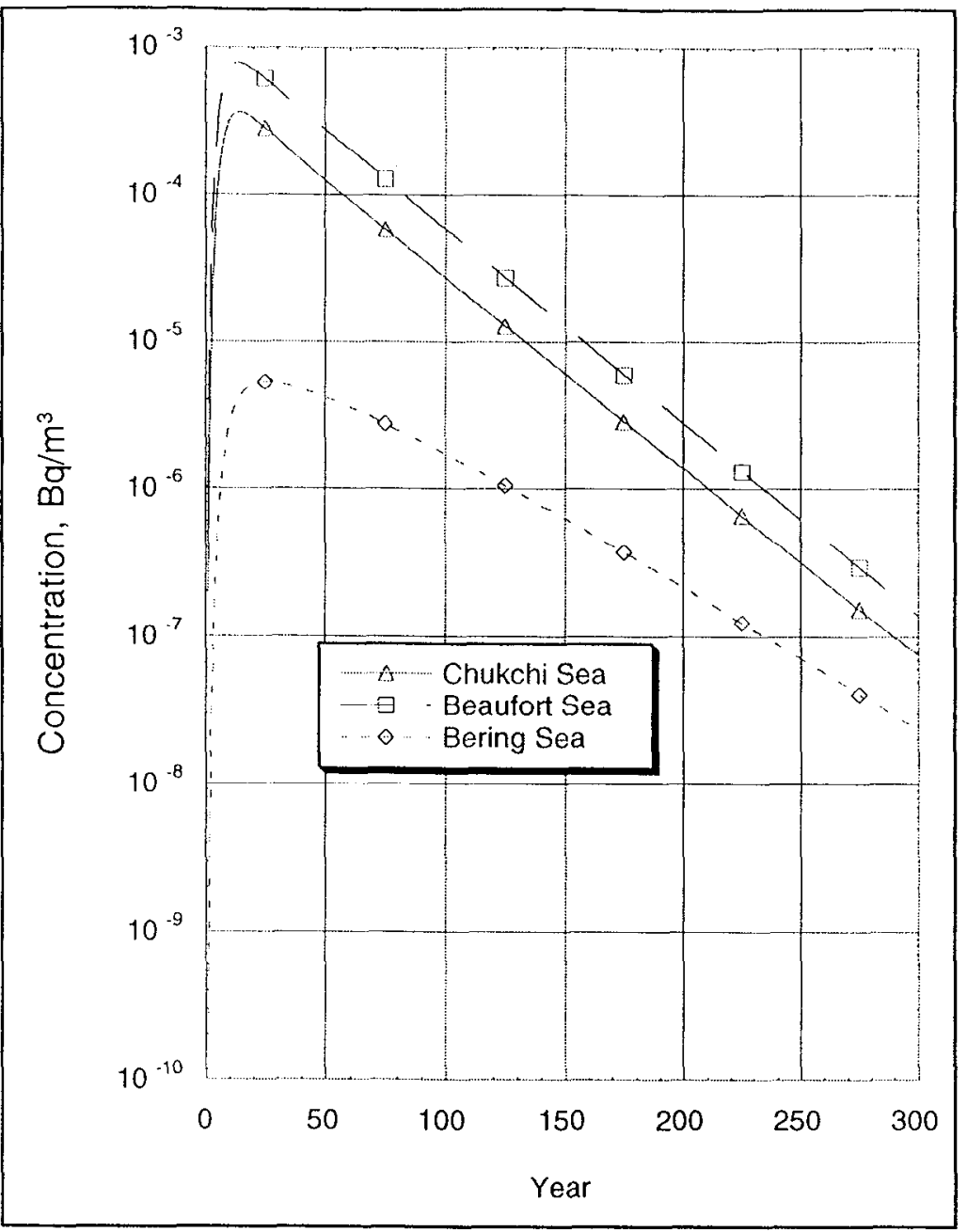

Figure 3-12. Concentrations of ${ }^{137} \mathrm{Cs}$ in the Beaufort, Bering, and Chukchi seas resulting from the accidental release of liquid waste from Mayak.

\section{Chronic Release}

The chronic release of ${ }^{90} \mathrm{Sr}$ is represented as a declining source term, based on an initial flux of 40 $\mathrm{TBq} / \mathrm{yr}$ into the Kara Sea estuary. The peak concentrations in the Beaufort and Chukchi seas are comparable to the peak levels predicted for the instantaneous release of ${ }^{90} \mathrm{Sr}$ to the Kara Sea and for accidental discharge of radioactive liquid wastes at Mayak; however, the peaks occur after 45 years of release (see Figure 3-13). 


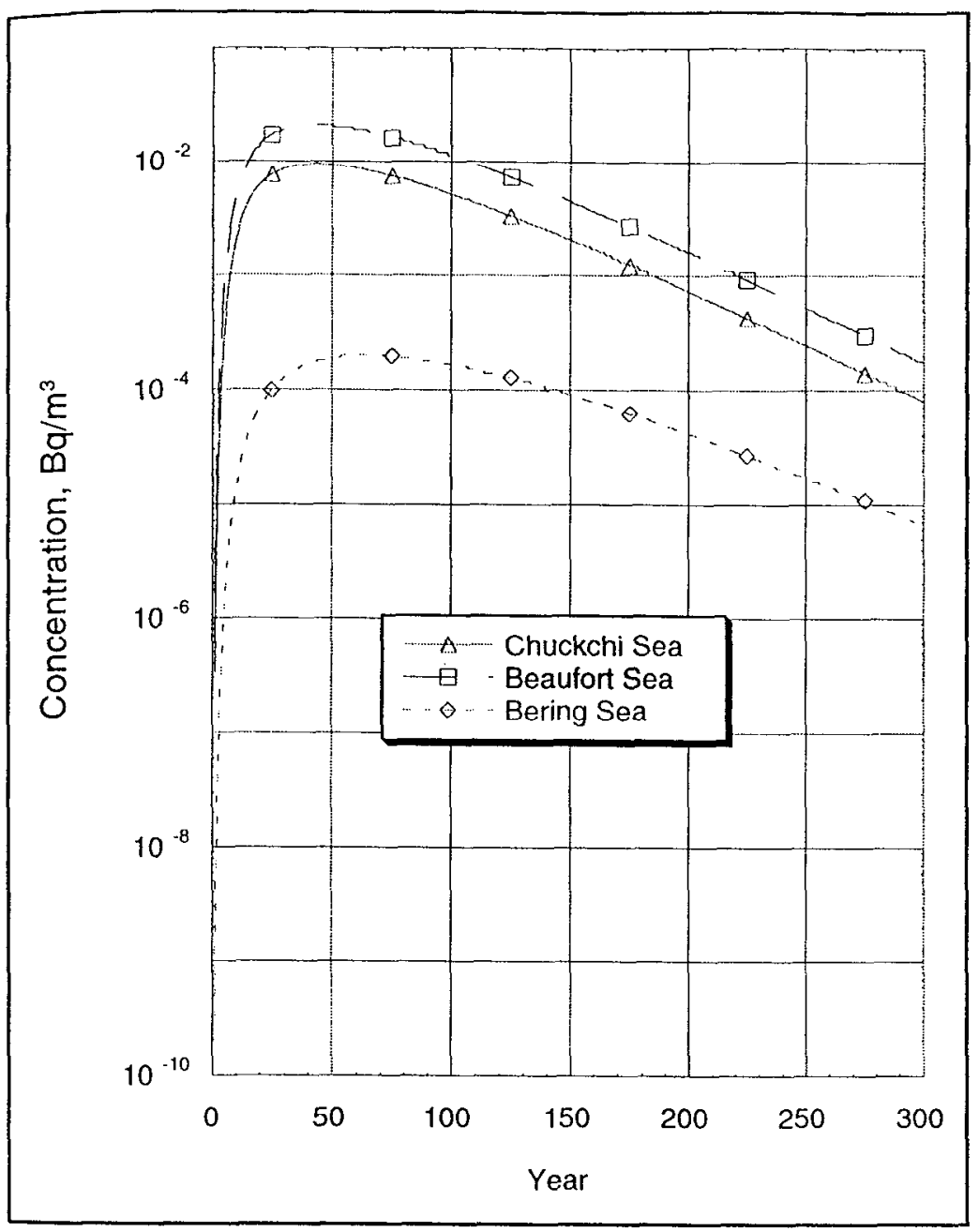

Figure 3-13. Concentrations of ${ }^{90} \mathrm{Sr}$ in the Beaufort, Bering, and Chukchi seas resulting from the chronic release of liquid wastes and watershed runoff into the $\mathrm{Ob}$ and Yenisey rivers.

\subsubsection{Predicted Radionuclide Concentrations v. Historic Levels}

Concentrations of ${ }^{241} \mathrm{Am},{ }^{137} \mathrm{Cs},{ }^{239,240} \mathrm{Pu}$, and ${ }^{90} \mathrm{Sr}$ in seawater have been measured since the early days of aboveground nuclear testing. As Section 2 discusses, nuclear fallout is a dominant source of fission products and actinides in the world's oceans. However, discharges from the nuclear reprocessing facility at Sellafield, U.K., also constitute an important source of such radionuclides for the Arctic Ocean because of ocean currents that transport reprocessing wastes from the Northeast Atlantic Ocean to the Norwegian and Greenland seas. To compare the predicted concentrations of radionuclides in the Chukchi, Beaufort, and Bering seas with their historic levels in those seas and other locations, following is a brief review of pertinent data on the key radionuclides sampled in Arctic Ocean as well as source waters in the Atlantic and Pacific oceans. 


\section{Arctic Seas and Source Waters of the Atlantic and Pacific Oceans}

Data on historic levels of fission products and actinides in Arctic waters adjacent to Alaska are sparse, but the available measurements do provide insights as to the sources of anthropogenic radionuclides in the Arctic seas. For example, an early study by Bowen and Sugihara (1964) showed that concentrations of ${ }^{90} \mathrm{Sr}$ in the Chukchi Sea gradually increased from $3.6 \mathrm{~Bq} / \mathrm{m}^{3}$ in 1959 to about $9 \mathrm{~Bq} / \mathrm{m}^{3}$ in 1962 . They attributed the increase to an influx of ${ }^{90} \mathrm{Sr}$ through the Bering Strait that was derived from seawater contaminated with fallout from nuclear testing in the Pacific Ocean. Data from Medinets et al. (1992) show radiocesium burdens in surface and near-surface waters of the Bering and Chukchi seas in 1988 of 1.6 to $3.7 \mathrm{~Bq} / \mathrm{m}^{3}$. Ellis et al. (1995) presented results of a polar cruise in 1994 that obtained seawater samples along a transect from the Chukchi Sea to the North Pole and then the Fram Strait. The greatest concentrations of ${ }^{137} \mathrm{Cs}$ were measured near the central portion of the Arctic Ocean $\left(7\right.$ to $\left.15 \mathrm{~Bq} / \mathrm{m}^{3}\right)$. In contrast, the lowest level $\left(1.9 \mathrm{~Bq} / \mathrm{m}^{3}\right)$ was detected in the Chukchi Sea. Ellis et al. concluded that the elevated levels of ${ }^{137} \mathrm{Cs}$ were derived from reprocessing wastes from European nuclear facilities, while the low concentration of ${ }^{137} \mathrm{Cs}$ in the Chukchi Sea was from Pacific water flowing through the Bering Strait with ${ }^{137} \mathrm{Cs}$ derived from global fallout from nuclear weapons testing.

Because inflowing Pacific water basically controls the level of radionuclides in the Chukchi Sea, the RAIG reviewed data on the concentrations of fission products and actinides in the central and northern portions of the Pacific Ocean to estimate historic and modern levels in Alaskan waters. For example, the average concentrations of ${ }^{241} \mathrm{Am},{ }^{137} \mathrm{Cs},{ }^{239,240} \mathrm{Pu}$, and ${ }^{90} \mathrm{Sr}$ in seawater to a depth of $80 \mathrm{~m}$ at one location in the northern Pacific Ocean sampled by Livingston et al. (1985) in 1973 were $0.004,6.1,0.012$, and $3.5 \mathrm{~Bq} / \mathrm{m}^{3}$, respectively. In a later study involving ${ }^{137} \mathrm{Cs},{ }^{239,240} \mathrm{Pu}$, and ${ }^{90} \mathrm{Sr}$ in the central North Pacific, Nagaya and Nakamura (1984) reported that the average concentrations of those nuclides in surface waters of the $35^{\circ}$ to $40^{\circ} \mathrm{N}$ latitudinal zone for the years 1980 and 1982 were 5.6, 0.038, and $4 \mathrm{~Bq} / \mathrm{m}^{3}$. As a point of comparison, Nikitin et al. (1991) estimated that the average concentration of ${ }^{137} \mathrm{Cs}$ in the 0 to $250 \mathrm{~m}$ layer of the Arctic Ocean in the 81 to $83^{\circ} \mathrm{N}$ latitude zone was $8.5 \mathrm{~Bq} / \mathrm{m}^{3}$ for the years $1985-1987$. The $2.5 \mathrm{~Bq} / \mathrm{m}^{3}$ increase over the $\sim 6$ $\mathrm{Bq} / \mathrm{m}^{3}$ level estimated for the Chukchi Sea (from the measurements in Pacific waters noted above) undoubtedly is due to the influx of ${ }^{137} \mathrm{Cs}$ from the Sellafield reprocessing facility via the northeast Atlantic Ocean.

In contrast, the level of ${ }^{137} \mathrm{Cs}$ in the Chukchi Sea in 1962 would have been approximately $14 \mathrm{~Bq} /$ $\mathrm{m}^{3}$, calculated from the concentration of $9 \mathrm{~Bq} / \mathrm{m}^{3}$ reported by Bowen and Sugihara (1964) and a multiplier of $\sim 1.5 \times$ concentration of ${ }^{90} \mathrm{Sr}$ (Volchok et al., 1971). Concentrations of ${ }^{241} \mathrm{Am}$ and ${ }^{239} \mathrm{Pu}$ in the early 1960s can also be estimated using ratios of the concentrations of those nuclides to the concentrations of ${ }^{90} \mathrm{Sr}$ in surface waters of the northern Pacific Ocean. The RAIG has calculated an average ${ }^{239} \mathrm{Pu} /{ }^{90} \mathrm{Sr}$ ratio of $\sim 0.005$ for these waters, based on the following set of concentration

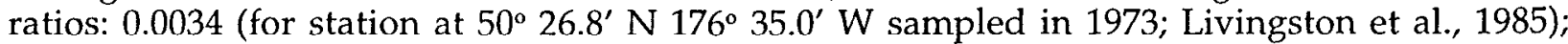
0.0075 (average for surface waters from stations 80-5, 80-6, and 80-8 sampled in 1980; Nagaya and Nakamura, 1984); and 0.0031 (for station at $30^{\circ} 03^{\prime} \mathrm{N} 170^{\circ} 03^{\prime} \mathrm{W}$ sampled in 1968, Miyake and Sugimura, 1976). The reconstructed ${ }^{239} \mathrm{Pu}$ concentration based on the measurement of ${ }^{90} \mathrm{Sr}$ for the 1962 sampling period is therefore $0.05 \mathrm{~Bq} / \mathrm{m}^{3}$. The concentration of ${ }^{241} \mathrm{Am}$ is estimated to have been $0.009 \mathrm{~Bq} / \mathrm{m}^{3}$, using a ${ }^{241} \mathrm{Am} /{ }^{90} \mathrm{Sr}$ ratio of about 0.001 determined from the station of Livingston et al. (1985). The RAIG estimates that the current concentration of ${ }^{90} \mathrm{Sr}$ in the Chukchi Sea is about $1 \mathrm{~Bq} / \mathrm{m}^{3}\left(1.9 \mathrm{~Bq} / \mathrm{m}^{3} \div 1.5\right)$, while the levels of ${ }^{241} \mathrm{Am}$ and ${ }^{239.240} \mathrm{Pu}$ would be about 0.001 and $0.005 \mathrm{~Bq} /$ $\mathrm{m}^{3}$, using the same ratios given above and the measured ${ }^{137} \mathrm{Cs}$ value of Ellis et al. (1995). 


\section{Comparisons with Predicted Levels}

Our estimates of the existing and historic concentrations of ${ }^{241} \mathrm{Am},{ }^{137} \mathrm{Cs},{ }^{239} \mathrm{Pu}$, and ${ }^{90} \mathrm{Sr}$ in Alaskan waters are all well above the levels associated with the peak doses for the different source-term scenarios, as summarized in Table 3-9. The highest predicted levels in Alaskan waters are associated with instantaneous releases of radionuclides from the nuclear wastes in the Kara Sea and from liquid-waste reservoirs at Mayak. Existing levels of ${ }^{90} \mathrm{Sr}$ are more than 20 times higher than predicted peak concentrations, and concentrations in the 1960 s are about another factor of 10 higher. The highest predicted concentration of ${ }^{137} \mathrm{Cs}$ is $0.032 \mathrm{~Bq} / \mathrm{m}^{3}$ in the Beaufort Sea after an instantaneous release to the Kara Sea. This level is much lower than the $2 \mathrm{~Bq} / \mathrm{m}^{3}$ of ${ }^{137} \mathrm{Cs}$ measured in the 1990s. The slow, time-varying release of nuclides from Kara Sea wastes from dissolution/corrosion processes is a more realistic source-term scenario, and the resulting concentrations for the four nuclides are far below both the historic and existing levels as well as those predicted for the unlikely instantaneous release case.

\subsection{SUMMARY}

- A compartmental modeling approach was used to simulate the transport of radionuclides derived from the Kara Sea nuclear wastes and riverine sources to Alaskan waters. Water flows between compartments were estimated using a coupled ice-ocean circulation model. Radionuclide losses within a given compartment occur via sedimentation and radioactive decay. The model is capable of simulating discrete as well as time-varying releases of radionuclides to ocean waters over long periods (decades or centuries).

- Site-specific data on sediment/water distribution coefficients $\left(\mathrm{K}_{d} s\right)$ for ${ }^{241} \mathrm{Am},{ }^{137} \mathrm{Cs},{ }^{239} \mathrm{Pu}$, and ${ }^{90} \mathrm{Sr}$ indicate that the $\mathrm{K}_{\mathrm{d}}$ s based on Kara Sea sediments are generally lower than default values used for coastal waters. Sediment loadings in the coastal portions of the Arctic Ocean are around $1 \mathrm{mg} / \mathrm{L}$, whereas in the central portion of the basin the levels are considerably lower, bascd on limited measurements. Because of the reduced $\mathrm{K}_{\mathrm{d}} \mathrm{s}$ and low particle loadings in the Arctic Ocean, water currents rather than sedimentation processes dominate nuclide transport.

- The role of ice formation and movement has been identified as a potential transport mechanism for radionuclide contaminants present in shallow areas of the Kara Sea. Our screeninglevel analyses indicate that the transport of radionuclides in coastal waters to the Arctic Ocean is probably a more dominant transport mechanism for such contaminants because the transport capacity of coastal water currents is greater than the capacity associated with ice and entrained sediment.

- The RAIG conducted a bench-marking exercise in which the team compared the results of the RAIG compartmental model with a modified version of one developed by Nielsen et al. (1995) to assess radionuclide transport in the Arctic Ocean. Both models provided similar results for ${ }^{137} \mathrm{Cs}$ and ${ }^{90} \mathrm{Sr}$, however, the concentrations predicted for ${ }^{239} \mathrm{Pu}$ and ${ }^{211} \mathrm{Am}$ in Alaskan waters based on their release into the Kara Sea were much lower in the Nielsen et al. model than in the RAIG model. This was attributed to increased scavenging of those particle-reactive nuclides in coastal compartments because of the $\mathrm{K}_{d} \mathrm{~s}$ used and the structure of the coastal compartments in the Nielsen et al. model. 
- Data on the concentrations of the four nuclides in Alaskan waters indicate that the highest levels occurred in the $1960 \mathrm{~s}$ as a result of global nuclear fallout. The predicted concentrations of the radionuclides in the Beaufort, Bering, and Chukchi seas were much lower than either historic or currents levels. This is not surprising given the $3,700 \mathrm{~km}$ transport distance between Novaya Zemlya and the north slope of Alaska. The highest predicted concentration of ${ }^{137} \mathrm{Cs}$ was $0.032 \mathrm{~Bq} / \mathrm{m}^{3}$ in the Beaufort Sea after an instantaneous release to the Kara Sea from nuclear wastes. This level is much lower than the $2 \mathrm{~Bq} / \mathrm{m}^{3}$ of ${ }^{137} \mathrm{Cs}$ measured in the $1990 \mathrm{~s}$. A more realistic release scenario, in which nuclides are released slowly to the Kara Sea as a result of corrosion and dissolution processes, results in predicted concentrations that are much lower.

- The RAIG model provides adequate detail for the assessment of potential risks to Alaska. It uses a large averaging near the sources of radionuclide release, and for this reason would not be as useful for resolving impacts in the immediate vicinity of the waste-disposal sites. 


\title{
4. Bioconcentration of Radionuclides in Marine Food-Web Organisms
}

\author{
W. Templeton ${ }^{\mathrm{a}}$, F. Harrison ${ }^{\mathrm{b}}$, J. Knezovich ${ }^{\mathrm{b}}$, N. Fisher ${ }^{\mathrm{c}}$, and D. Layton ${ }^{\mathrm{b}}$
}

aBattelle Pacific Northwest Laboratories, Richland, WA

bLawrence Livermore National Laboratory, Livermore, CA

cState University of New York, Stony Brook, NY

oncentrations of radionuclides in seawater, particles, and marine species are important
inputs to radiological assessments involving the health and ecological impacts of radionu-
clide releases to the marine environment. In our assessment of the potential consequences
of nuclear wastes in the Arctic Ocean, the RAIG focuses primarily on future releases. Therefore,
predicted concentrations of nuclides in Arctic waters must be translated to the associated pos-
sible concentrations in marine species. Historically, radiological assessments have used a derived
parameter, termed a concentration factor or bioconcentration factor (BCF), that links the concen-
tration of a nuclide in the whole body or a tissue of a marine organism to its concentration in
seawater. This section describes the basis of such factors and analyzes applicable values for the
principal radionuclides addressed in this assessment (i.e., ${ }^{90} \mathrm{Sr},{ }^{137} \mathrm{Cs},{ }^{241} \mathrm{Am}$, and ${ }^{239} \mathrm{Pu}$ ) and for
naturally occurring radionuclides that are reported to deliver the greatest dose to the organisms.
Finally, the RAIG uses the BCFs along with measured and predicted concentrations of radionu-
clides in Arctic waters to estimate levels of radionuclides in marine species.

\subsection{Definition of Bioconcentration Factors}

Marine organisms accumulate exogenous substances present in food, water, and particles by various mechanisms. For example, the consumption of contaminated foods (i.e., food-chain transfer), direct uptake from water, and ingestion/filtration of contaminated particulate matter each may contribute to the exposure of an organism to radionuclides. The term bioaccumulation is used to acknowledge that organisms exposed to contaminants in the field derive their body burdens from a variety of sources. While it may be possible to simulate bioaccumulation processes for some organisms under controlled conditions, it is simply not possible to characterize accurately such processes over a suite of marine species and environments.

A simpler approach is to determine a contaminant's concentration in a given organism as a function of its concentration in water. More specifically, the basic approach for determining a 
bioconcentration factor (BCF) has been to calculate it as the ratio of a contaminant's concentration in the whole body or target tissue of interest (e.g., muscle) to the concentration of the contaminant in water. A BCF can be expressed as a unitless ratio if the radionuclide concentrations are expressed on a mass basis (e.g., Bq $/ \mathrm{kg}$ wet weight in tissue $\div \mathrm{Bq} / \mathrm{kg}$ of seawater), or it can be expressed in units of $\mathrm{L} / \mathrm{kg}$ (e.g., Bq $/ \mathrm{kg}$ wet weight in tissue $\div \mathrm{Bq} / \mathrm{L}$ of seawater) or $\mathrm{m}^{3} / \mathrm{kg}$ (e.g., $\mathrm{Bq} / \mathrm{kg}$ wet weight in tissue $\div \mathrm{Bq} / \mathrm{m}^{3}$ of seawater). In this risk assessment, the units are presented both as traditional unitless ratios and in units of $\mathrm{m}^{3} / \mathrm{kg}$, which are consistent with the circulation models developed to predict the concentrations in seawater. These latter BCF values are $1 / 1,000$ of that of the unitless quantity found in most publications.

A BCF is thus a parameter that represents the net effects of all bioaccumulation and elimination processes affecting the transfer of a radionuclide from food, water, and particles to an organism. The application of this approach is based on the assumption that organisms, their prey items, and particulate matter are at or near steady state with the dissolved fraction of a contaminant. This is a reasonable assumption for the assessment of future releases of radionuclides expected to result in relatively small spatial and temporal variations in their dissolved concentrations. Some authors also have calculated BCFs from radionuclide concentrations in food-chain organisms and in sediments. The use of BCFs based on specific biotic and abiotic components is appropriate when sufficient data are available indicating the component is the actual source of the radionuclide to the organism of interest. Because relatively little information is available for BCFs based on exposure media other than water, only water-derived BCFs were used for our assessments.

Three idealized patterns of BCFs have been described by Vanderploeg et al. (1975). The first pattern is that the BCF of a nuclide in biological material is constant (i.e., is unaffected by the concentration of the nuclide in the water). This pattern is shown by nuclides that are not under homeostatic control (regulated to a specific concentration); an example is the behavior of plutonium in marine invertebrates and fishes. The second pattern is that the BCF of the nuclide is inversely proportional to its concentration in the water. This is characteristic of nuclides that are under homeostatic control (e.g., ${ }^{131} \mathrm{I}$ in whales). The third pattern is that the BCF for the nuclide is inversely proportional to the concentration of a non-isotopic carrier element (i.e., chemically similar to but occurring in higher concentrations than the stable-element analog). The classical example of this pattern is cesium in freshwater animals; the non-isotopic carrier element is potassium in this case. This pattern is shown by very few radionuclides in marine organisms.

Scientists have directed considerable attention to the determination of BCFs. They have calculated values from analyses of stable and radioactive nuclides in field samples, have assessed them in laboratory experiments, and have determined wide ranges in BCFs for some organisms (Jackson et al., 1983; Noshkin, 1985; Harrison, 1986, Gomez et al., 1991; Radioactive Waste Management Center, 1996). A number of factors may contribute to the large variability in BCF values for the same group of organisms (Harrison, 1986). Important among these for the water include (1) the concentration being determined from filtered v. unfiltered water, (2) the differences in physicochemical form of nuclides among ecosystems, and (3) the absence of steady-state conditions from changing source terms. Metabolic demands and physiological state may result in differences in the BCF with season. Also, part of the variability in BCFs can be attributed to the samples being collected in ecosystems where steady-state conditions with abiotic and biotic components were not present.

The International Atomic Energy Agency (IAEA, 1978, 1985) compiled listings of values and ranges for sixty elements in surface water fishes, crustaceans, mollusks, macroalgae, zooplankton, phytoplankton, cephalopods, and mesopelagic fishes. The approach used in the 1985 assessment was "to review the literature in order to select the most appropriate BCFs for radionuclides in marine 
biological materials based, whenever possible, on field data." The data base upon which their recommended values were obtained differed greatly among the sixty elements.

\subsection{Bioconcentration Factors for Radionuclides Derived FROM FSU SOURCES}

In the initial stages of ANWAP, some concern was expressed that because the IAEA-recommended $B C F$ values were not derived from measurements of Arctic biological materials but were obtained in organisms from temperate and tropical regions, the BCFs may be inappropriate. Some laboratory experiments for specific organisms, i.e., the brown seaweed (Fucus vesiculosus) and the brittle star (Ophiothrix fragilis), were conducted (Povinec et al., 1996). Scientists from both the IAEA and the IAEA's Marine Environment Laboratory reviewed these experiments and other data and concluded that no evidence indicates any significant difference between BCFs derived from organisms indigenous to temperate and Arctic waters. A larger database, however, must substantiate this conclusion.

In 1995 the IAEA convened a panel of consultants who reviewed all of the available data and recommended BCFs for use in the Arctic ecosystems. One of the authors of this report (N. Fisher) was a member of that group (IAEA Working Group papers, 1995). The recommended BCF values for radionuclides in muscles of Arctic fish are given in Table 4-1, for marine mammals in Table 42 , and for seabirds in Table 4-3. The BCF data for seabirds is based on the assumption that their exposures to radionuclides were primarily from prey items that were in contact with seawater. The majority of seawater and biological samples were collected in the eastern Arctic. ANWAP has sponsored the collection of samples from the western Arctic, particularly the Beaufort, Chukchi, and Bering Seas. However, the data are not yet available from which to calculate site-specific $\mathrm{BCF}$ for organisms from Alaskan waters. 
Table 4-1. Recommended bioconcentration factors for fish flesh in temperate and Arctic waters.

\begin{tabular}{|c|c|c|c|c|c|}
\hline \multirow[b]{2}{*}{ Element } & \multicolumn{2}{|c|}{$\begin{array}{l}\text { Recomn } \\
\text { Temperate waters }^{\text {a }} \\
\end{array}$} & \multicolumn{2}{|c|}{ Arctic waters ${ }^{b}$} & \multirow[b]{2}{*}{ Species $^{\mathrm{C}}$} \\
\hline & $\mathrm{m}^{3} / \mathrm{kg}$ & Unitless & $\mathrm{m}^{3} / \mathrm{kg}$ & Unitless & \\
\hline$\overline{\mathrm{Sr}}$ & $2 \times 10^{-3}$ & $2 \times 10^{0}$ & $2 \times 10^{3}$ & $4 \times 10^{0}$ & $\begin{array}{l}\text { Cod, Plaice, Halibut, } \\
\text { Haddock, Saithe, Seawolf, } \\
\text { Red Fish, Ray, Salmon }\end{array}$ \\
\hline Cs & $1 \times 10^{-1}$ & $1 \times 10^{2}$ & $1 \times 10^{-1}$ & $1 \times 10^{2}$ & $\begin{array}{l}\text { Cod, Plaice, Haddock, } \\
\text { Saithe, Seawolf, Red Fish, } \\
\text { Ray, Halibut, Salmon, Polar } \\
\text { Cod, Char }\end{array}$ \\
\hline $\mathrm{Pu}$ & $4 \times 10^{-2}$ & $4 \times 10^{1}$ & $4 \times 10^{-2}$ & $4 \times 10^{1}$ & Haddock, Sea Scorpion, Cod \\
\hline Am & $5 \times 10^{-2}$ & $5 \times 10^{1}$ & & & \\
\hline Po & $2 \times 10^{0}$ & $2 \times 10^{3}$ & & & \\
\hline \multicolumn{6}{|c|}{ a Values recommended for fish in temperate waters are from the IAEA (1985). } \\
\hline \multicolumn{6}{|c|}{ b Values recommend for fish in Arctic waters are from IAEA Working Group. } \\
\hline \multicolumn{6}{|c|}{ c Species addressed in the review of the IAEA Working Group. } \\
\hline
\end{tabular}

Table 4-2. Actual and recommended bioconcentration factors for sea mammal muscle (from the IAEA Working Group).

Bioconcentration Factors

\begin{tabular}{|c|c|c|c|c|c|}
\hline \multirow[b]{2}{*}{ Element } & \multirow{2}{*}{$\begin{array}{l}\text { Range } \\
\mathrm{m}^{3} / \mathrm{kg}\end{array}$} & \multicolumn{4}{|c|}{$\begin{array}{l}\text { Recommended } \\
\text { Values }\end{array}$} \\
\hline & & $\mathrm{m}^{3} / \mathrm{kg}$ & $\mathrm{m}^{3} / \mathrm{kg}$ & Unitless & Species \\
\hline \multirow[t]{2}{*}{$\mathrm{Sr}$} & $4 \times 10^{-4}$ to $1.2 \times 10^{-3}$ & $7 \times 10^{-4}$ & $1 \times 10^{-3}$ & $1 \times 10^{0}$ & Seal \\
\hline & $2 \times 10^{-4}$ to $3 \times 10^{-3}$ & $1.1 \times 10^{-3}$ & $1 \times 10^{-3}$ & $1 \times 10^{0}$ & Whale \\
\hline \multirow[t]{2}{*}{ Cs } & $1.3 \times 10^{-2}$ to $1.8 \times 10^{-1}$ & $1 \times 10^{-1}$ & $1 \times 10^{-1}$ & $1 \times 10^{2}$ & Seal \\
\hline & $4 \times 10^{-1}$ to $1.3 \times 10^{-1}$ & $1 \times 10^{-1}$ & $1 \times 10^{-1}$ & $1 \times 10^{2}$ & Whale \\
\hline \multirow[t]{2}{*}{$\mathrm{Pu}$} & & $<3 \times 10^{-3}$ & $3 \times 10^{-3}$ & $3 \times 10^{0}$ & Seal \\
\hline & & $4 \times 10^{-3}$ & $3 \times 10^{-3}$ & $3 \times 10^{0}$ & Walrus \\
\hline
\end{tabular}


Table 4-3. Actual and recommended bioconcentration factors for seabirds in the Arctic (from IAEA Working Group).

\begin{tabular}{|c|c|c|c|c|c|}
\hline \multirow[b]{2}{*}{ Elemen } & \multicolumn{5}{|c|}{$\begin{array}{l}\text { Bioconcentration Factors } \\
\text { Recommended }\end{array}$} \\
\hline & $\begin{array}{l}\text { Range } \\
\mathrm{m}^{3} / \mathrm{kg}\end{array}$ & $\begin{array}{l}\text { Mean } \\
\mathrm{m}^{3} / \mathrm{kg}\end{array}$ & $\begin{array}{l}\text { Values } \\
\mathrm{m}^{3} / \mathrm{kg}\end{array}$ & Unitless & Species \\
\hline Cs & $4 \times 10^{-2}$ to $1.1 \times 10^{0}$ & $4 \times 10^{-1}$ & $1 \times 10^{-1}$ & $1 \times 10^{2}$ & $\begin{array}{l}\text { Auk, Great Black Backed } \\
\text { Gull, Common Gull, Great } \\
\text { Skus, Spotted Redshank, } \\
\text { Sandpiper and Goosander. } \\
\text { Goosander has the lowest } \\
\text { BCF, } 4 \times 10^{-1}\end{array}$ \\
\hline
\end{tabular}

$\mathrm{Pu} \quad<2 \times 10^{-2}$ to $1.5 \times 10^{-1} \quad 1 \times 10^{-1} \quad 1 \times 10^{-1} \quad 1 \times 10^{2} \quad$ Guillemot and Eider

\subsection{Bioconcentration Factors for Naturally Occurring RADIONUCLIDES}

Naturally occurring radionuclides in the marine environment contribute significantly to the background doses received by some marine organisms (IAEA, 1976, 1985). Dose rates calculated for a series of natural radionuclides in phytoplankton, zooplankton, mollusks, crustacea, and fishes indicated that the significant doses were contributed from internal emitters ${ }^{40} \mathrm{~K}$ and ${ }^{210} \mathrm{Po}$. The radionuclide ${ }^{40} \mathrm{~K}$ is of limited interest because it is an isotope of an essential element that is under homeostatic control and its concentrations are determined primarily by body build and type. ${ }^{210} \mathrm{Po}$ is of special interest because it is the decay product of ${ }^{210} \mathrm{Bi}$, which is the daughter of naturally occurring ${ }^{210} \mathrm{~Pb}\left({ }^{210} \mathrm{~Pb} \rightarrow{ }^{210} \mathrm{Bi} \longrightarrow{ }^{210} \mathrm{Po}\right)$ and has a relatively short half-life of $140 \mathrm{~d}$.

Data are available indicating that ${ }^{210} \mathrm{Po}$ is accumulated in different tissues of marine organisms to levels greater than those resulting from the decay of its long-lived precursor ${ }^{210} \mathrm{~Pb}$ (Noshkin et al., 1984; Noshkin et al., 1994; and Aarkrog et al., 1997). Holtzman (1980) provided information on the normal dietary levels of ${ }^{210}$ Po for individuals from different countries and attributed the higher intake for Japanese to be due to the high seafood consumption and that from Arctic dwellers to be due to consumption of reindeer and caribou meat. In an in-depth study of the concentrations of ${ }^{210} \mathrm{Po}$ and ${ }^{210} \mathrm{~Pb}$ in the diet of the Marshallese, Noshkin et al. (1994) provided mean values and ranges in values of ${ }^{210} \mathrm{Po}$ in fishes, invertebrates, seabirds, and vegetation. The data on fishes show large variation in concentrations with species. Comparable variability was shown for invertebrates and seabirds. Noshkin et al. (1994) and Aarkrog et al. (1997) discuss the variability among species and within the same species. They note that the differences do not appear to be related to trophic level, but may be related to the differences in the types of tissue consumed, citing the large variability in ${ }^{210} \mathrm{Po}$ content of the viscera.

The comprehensive review by Aarkrog et al. (1997), an international group of scientists, summarized published data on the two radionuclides ${ }^{137} \mathrm{Cs}$ and ${ }^{20} \mathrm{Po}$, providing not only $\mathrm{BCF}$ but also 
doses to persons in different geographical areas. Their recommended $\mathrm{BCF}$ values for ${ }^{137} \mathrm{Cs}$ were 100 and 30 and for ${ }^{210}$ Po were 2,000 and 30,000 for fish and shellfish, respectively. The water concentrations they used for ${ }^{210} \mathrm{Po}$ was $1 \mathrm{~Bq} / \mathrm{m}^{3}$. Noshkin et al. (1994) calculated the BCF for flesh from all fish in the Marshall Islands to be $1.2 \times 10^{4}$; their BCFs were based on the water concentration of ${ }^{210}$ Po for the equatorial Pacific (i.e., $1.15 \mathrm{~Bq} / \mathrm{m}^{3}$ ). The Noshkin et al. (1994) value is six times greater than that of Aarkrog et al. (1996) and two times greater than the mean value computed by Carvalho (1988) for muscle of epipelagic teleosts from the Atlantic (Noshkin et al., 1994). It should be taken into consideration that Noshkin et al. (1994) obtained all their data using the same methodology, which had been calibrated with international standards, and the BCFs were all based on filtered seawater. Thus, the high variability undoubtedly is real and represents physiological or chemical factors that still are unresolved. In consideration of the doses received from ${ }^{210} \mathrm{Po}$ by native Alaskans, it is important to recognize not only the large differences in concentrations among food sources but also that the time between the collection and consumption of the material becomes significant because of ${ }^{210} \mathrm{Po}^{\prime}$ s relatively short half-life.

\subsection{ARIABilities in Bioconcentration Factors}

Previous reviews of BCFs (Jackson et al., 1983; Noshkin, 1985; Harrison, 1986; Gomez et al., 1991; RWMC, 1996), have demonstrated that BCF values are highly variable and that they usually fit $\log$ normal probability distributions rather than normal distributions. As a means of characterizing this variability, the RAIG has prepared log probability plots of the $\mathrm{BCF}$ values for ${ }^{137} \mathrm{Cs}$ in fish and birds (Tables 4-4 and 4-5), and for ${ }^{90} \mathrm{Sr}$ in fish (Table 4-4). Figure 4-1 shows the resulting probability plots. The geometric means of the BCF values for ${ }^{137} \mathrm{Cs}$ in fish and birds are 120 and 340 , respectively. The geometric standard deviation (GSD) of the BCF for fish was 1.6, while that for seabirds was larger (i.e., 2.7). The geometric mean value of the BCF values for ${ }^{90} \mathrm{Sr}$ in fish is 4.33 , with a GSD of 2.4 .

The degree of variability that surrounds the BCF data presented in Figure 4-1 is reasonable in light of the variabilities associated with the age, sex, and exposure history of each species. The GSD for ${ }^{137} \mathrm{Cs}$ accumulation in fish is relatively low (i.e., 1.6), which indicates that water-based exposures represent a reasonable approximation of exposure for this radionuclide. Although the GSD for ${ }^{90} \mathrm{Sr}$ accumulation in fish is higher (i.e., 2.4), the accumulation of this radionuclide is relatively low. The relatively high variability of ${ }^{137} \mathrm{Cs}$ accumulation in birds most likely is due to the fact that these species have limited contact with seawater. Their exposure, therefore, largely is due to the ingestion of prey items. Because prey items and other food sources can have terrestrial as well as marine sources, and be from different trophic levels, the use of water-based BCF values could be expected to yield variable results. 


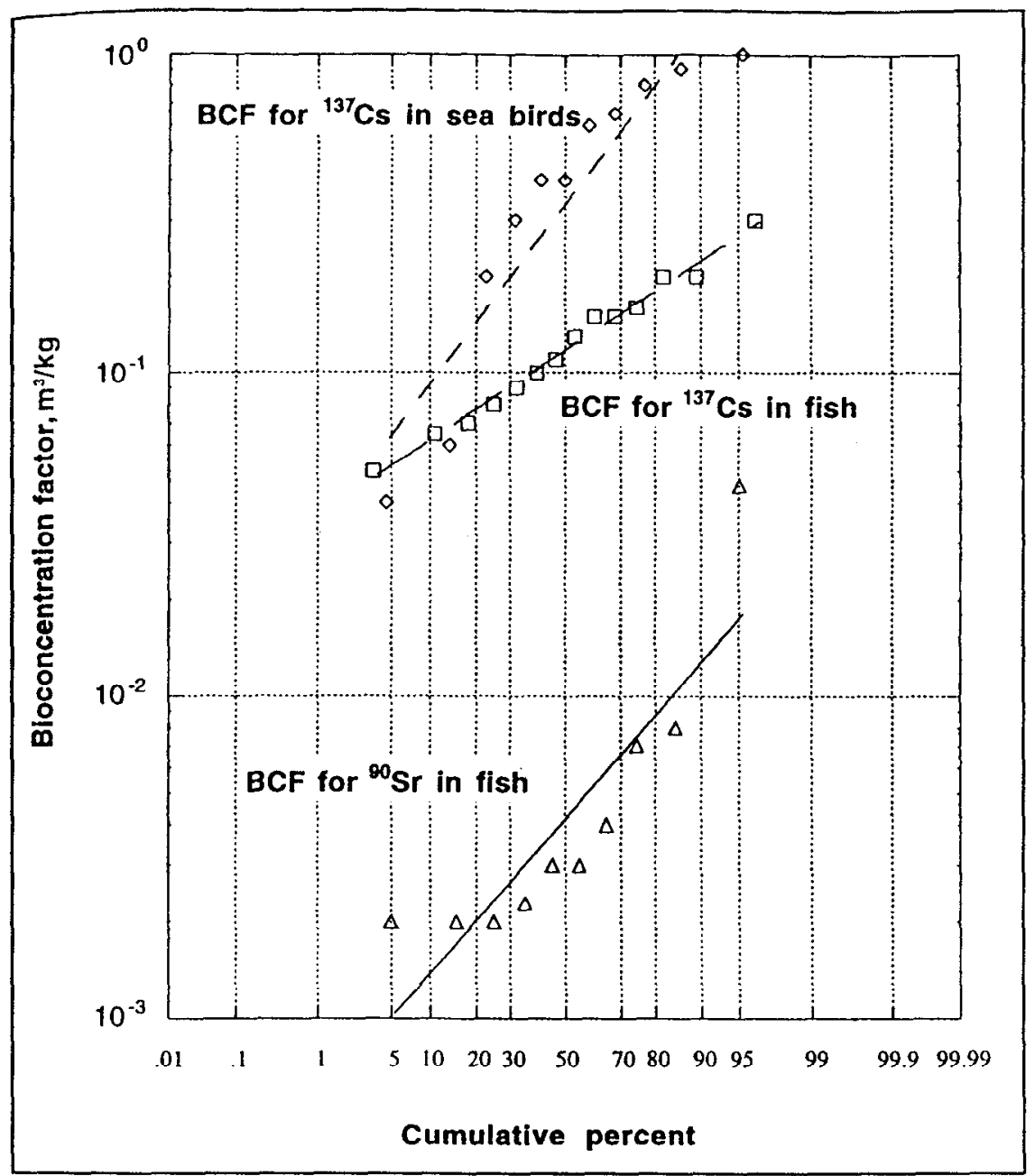

Figure 4-1. Log probability plots of the bioconcentration factors for ${ }^{137} \mathrm{Cs}$ in seabirds and fish, and for ${ }^{90} \mathrm{Sr}$ in fish. Data are from Tables 4-4 and 4-5. 
Table 4-4. Bioconcentration factors for fish tissues based.on measured values of nuclides in water and fish for Arctic Waters (from IAEA Working Group).

\begin{tabular}{|c|c|c|c|c|}
\hline \multirow{2}{*}{$\begin{array}{l}\text { Nuclide/ } \\
\text { Element }\end{array}$} & \multirow[b]{2}{*}{ Area } & \multirow[b]{2}{*}{ Species } & \multicolumn{2}{|c|}{ Bioconcentration Factor } \\
\hline & & & $\mathrm{m}^{3} / \mathrm{kg}$ & Unitless \\
\hline \multirow[t]{10}{*}{${ }^{90} \mathrm{Sr}$} & Barents Sea & Cod Muscle & $8 \times 10^{-3}$ & $8 \times 10^{0}$ \\
\hline & & Plaice Muscle & $2 \times 10^{-3}$ & $2 \times 10^{0}$ \\
\hline & & Haddock Muscle & $4 \times 10^{-3}$ & $4 \times 10^{0}$ \\
\hline & & Saithe Muscle & $3 \times 10^{-3}$ & $3 \times 10^{0}$ \\
\hline & & Seawolf Muscle & $2 \times 10^{-3}$ & $2 \times 10^{0}$ \\
\hline & & Red Fish Muscle & $7 \times 10^{-3}$ & $7 \times 10^{0}$ \\
\hline & & Ray Muscle & $3 \times 10^{-3}$ & $3 \times 10^{0}$ \\
\hline & $\begin{array}{l}\text { Around } \\
\text { Greenland }\end{array}$ & Salmon Muscle & $2 \times 10^{-4}$ to $9 \times 10^{-2}$ & $2 \times 10^{-1}$ to $9 \times 10^{1}$ \\
\hline & & Halibut Muscle & $3 \times 10^{-4}$ to $2 \times 10^{-3}$ & $3 \times 10^{-1}$ to $2 \times 10^{0}$ \\
\hline & & Cod Muscle & $2 \times 10^{-3}$ & $2 \times 10^{0}$ \\
\hline \multirow[t]{14}{*}{${ }^{137}{ }_{C s}$} & Barents Sea & Cod Muscle & $1.6 \times 10^{-1}$ & $1.6 \times 10^{2}$ \\
\hline & & Plaice Muscle & $1.1 \times 10^{-1}$ & $1.1 \times 10^{2}$ \\
\hline & & Haddock Muscle & $1.0 \times 10^{-1}$ & $1.0 \times 10^{2}$ \\
\hline & & Saithe Muscle & $9 \times 10^{-2}$ & $9 \times 10^{1}$ \\
\hline & & Seawolf Muscle & $8 \times 10^{2}$ & $8 \times 10^{1}$ \\
\hline & & Red Fish Muscle & $2 \times 10^{-1}$ & $2 \times 10^{2}$ \\
\hline & & Ray Muscle & $1.5 \times 10^{-1}$ & $1.5 \times 10^{2}$ \\
\hline & & Halibut Muscle & $1.5 \times 10^{-1}$ & $1.5 \times 10^{2}$ \\
\hline & Barents Sea & Fish Muscle & $3 \times 10^{-2}$ to $2 \times 10^{-1}$ & $3 \times 10^{1}$ to $2 \times 10^{2}$ \\
\hline & Abrosimov Fjord & Polar Cod Muscle & $3 \times 10^{-1}$ & $3 \times 10^{2}$ \\
\hline & & Char Muscle & $2 \times 10^{-1}$ & $2 \times 10^{2}$ \\
\hline & $\begin{array}{l}\text { Around } \\
\text { Greenland }\end{array}$ & Salmon Muscle & $5 \times 10^{-4}$ to $1.3 \times 10^{-1}$ & $5 \times 10^{-1}$ to $1.3 \times 10^{2}$ \\
\hline & & Halibut Muscle & $4 \times 10^{-2}$ to $6 \times 10^{-2}$ & $4 \times 10^{1}$ to $6 \times 10^{1}$ \\
\hline & & Cod Muscle & $7 \times 10^{-2}$ & $7 \times 10^{1}$ \\
\hline \multirow[t]{4}{*}{$239,240 \mathrm{Pu}$} & Barents Sea & Ray, Muscle & $1.8 \times 10^{0}$ & $1.8 \times 10^{3}$ \\
\hline & & Other Fish Species, Muscle & $<5 \times 10^{-1}$ & $<5 \times 10^{2}$ \\
\hline & & Haddock, Liver & $4 \times 10^{0}$ & $4 \times 10^{3}$ \\
\hline & Grcenland Thule & $\begin{array}{c}\text { Sea Scorpion and Cod, } \\
\text { Muscle }\end{array}$ & $8 \times 10^{-2}$ & $8 \times 10^{1}$ \\
\hline
\end{tabular}


Table 4-5. Bioconcentration factors for seabirds (from IAEA Working Group).

\begin{tabular}{|c|c|c|c|c|}
\hline \multirow[b]{2}{*}{ Nuclide } & \multirow[b]{2}{*}{ Area } & \multirow[b]{2}{*}{ Species } & \multicolumn{2}{|c|}{ Bioconcentration Factor } \\
\hline & & & $\mathrm{m}^{3} / \mathrm{kg}$ & Unitless \\
\hline \multirow[t]{12}{*}{${ }^{137} \mathrm{Cs}$} & $\begin{array}{l}\text { Around } \\
\text { Greenland }\end{array}$ & Auk, Muscle & $5 \times 10^{-2}$ to $7 \times 10^{-2}$ & $5 \times 10^{1}$ to $7 \times 10^{1}$ \\
\hline & $\begin{array}{c}\text { Kola } \\
\text { Peninsula }\end{array}$ & $\begin{array}{l}\text { Gt. Black-Backed } \\
\text { Gull, Muscle }\end{array}$ & $5 \times 10^{1}$ to $1.1 \times 10^{0}$ & $5 \times 10^{2}$ to $1.1 \times 10^{3}$ \\
\hline & & $\begin{array}{l}\text { Gt. Black-Backed } \\
\text { Gull, Liver }\end{array}$ & $4 \times 10^{-1}$ to $9 \times 10^{-1}$ & $4 \times 10^{2}$ to $9 \times 10^{2}$ \\
\hline & & $\begin{array}{l}\text { Common Gull, } \\
\text { Muscle }\end{array}$ & $2 \times 10^{-1}$ & $2 \times 10^{2}$ \\
\hline & & Common Gull, Liver & $2 \times 10^{-1}$ & $2 \times 10^{2}$ \\
\hline & & Great Skus, Muscle & $6 \times 10^{-1}$ & $6 \times 10^{2}$ \\
\hline & & Great Skus, Liver & $4 \times 10^{-1}$ & $4 \times 10^{2}$ \\
\hline & & $\begin{array}{l}\text { Spotted Redshank, } \\
\text { Muscle }\end{array}$ & $9 \times 10^{-1}$ & $9 \times 10^{2}$ \\
\hline & & $\begin{array}{c}\text { Spotted Redshank, } \\
\text { Liver }\end{array}$ & $1 \times 10^{0}$ & $1 \times 10^{3}$ \\
\hline & & Sandpiper, Muscle & $3 \times 10^{-1}$ & $3 \times 10^{2}$ \\
\hline & & Sandpiper, Liver & $4 \times 10^{-1}$ & $4 \times 10^{2}$ \\
\hline & & Goosander, Muscle & $4 \times 10^{-2}$ & $4 \times 10^{1}$ \\
\hline \multirow[t]{2}{*}{$239,240 \mathrm{Pu}$} & $\begin{array}{l}\text { Greenland } \\
\text { Thule }\end{array}$ & $\begin{array}{l}\text { Guillemot and Eider, } \\
\text { Muscle }\end{array}$ & $<2 \times 10^{-2}$ to $1.5 \times 10^{-1}$ & $<2 \times 10^{1}$ to $1.5 \times 10^{2}$ \\
\hline & & $\begin{array}{c}\text { Guillemot and Eider, } \\
\text { Liver }\end{array}$ & $6 \times 10^{-2}$ to $2 \times 10^{0}$ & $6 \times 10^{1}$ to $2 \times 10^{3}$ \\
\hline
\end{tabular}



Table 4-6. Bioconcentration factors (unitless) selected for use in risk assessment for different groups of
marine organisms in Arctic seas. The bioconcentration factors were those in IAEA (1985), except where noted.

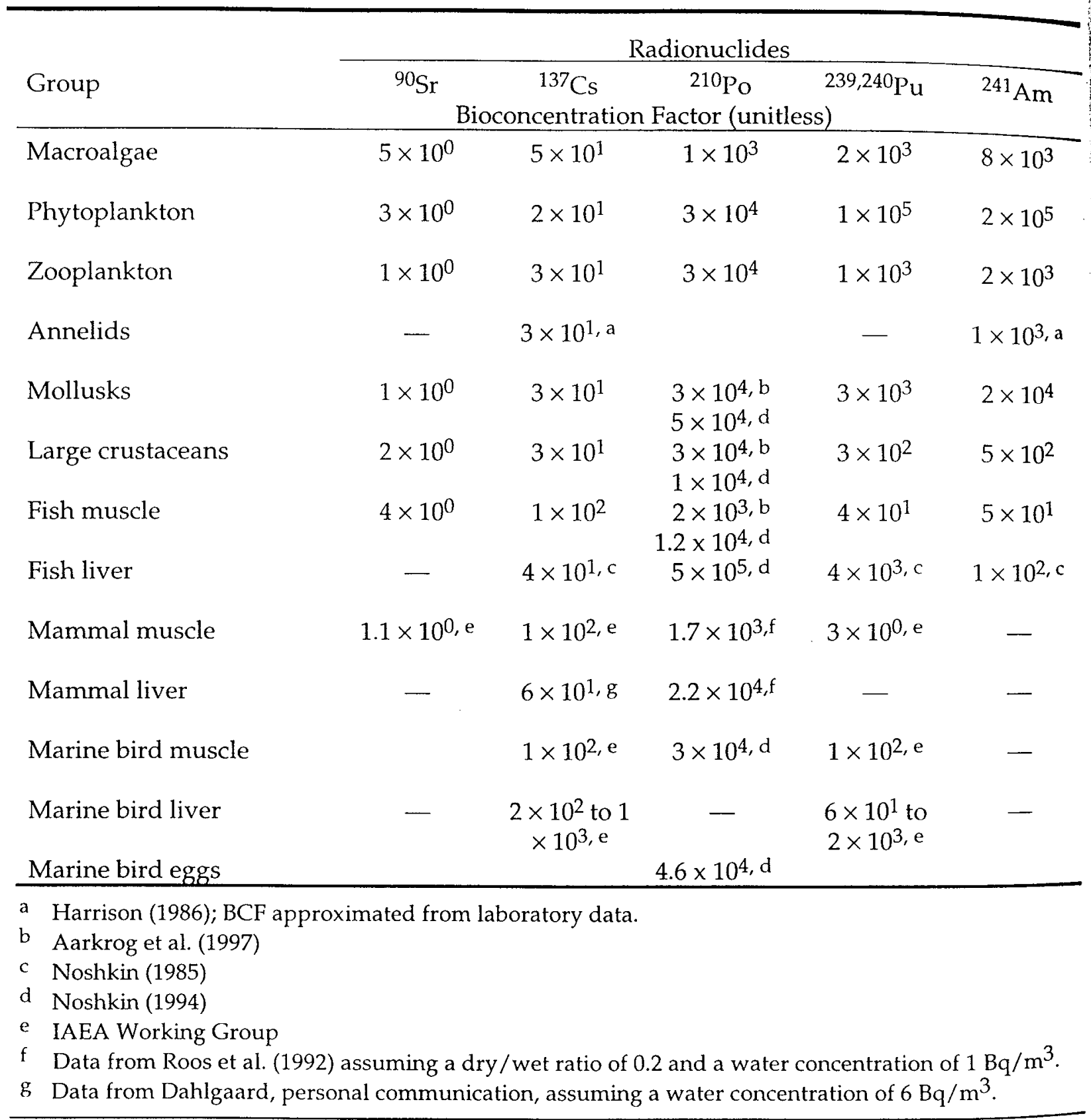


Table 4-7. Bioconcentration factors $\left(\mathrm{m}^{3} / \mathrm{kg}\right)$ selected for use in risk assessment for different groups of marine organisms in Arctic seas. The bioconcentration factors were those in IAEA (1985), except where noted.

\begin{tabular}{|c|c|c|c|c|c|}
\hline \multirow{3}{*}{ Group } & \multicolumn{5}{|c|}{ Radionuclides } \\
\hline & $90 \mathrm{Sr}$ & ${ }^{137} \mathrm{Cs}$ & ${ }^{210} \mathrm{Po}$ & $239,240 \mathrm{Pu}$ & ${ }^{241} \wedge \mathrm{m}$ \\
\hline & \multicolumn{5}{|c|}{ Bioconcentration Factor $\left(\mathrm{m}^{3} / \mathrm{kg}\right)$} \\
\hline Macroalgae & $5 \times 10^{-3}$ & $5 \times 10^{-2}$ & $1 \times 10^{0}$ & $2 \times 10^{0}$ & $8 \times 10^{0}$ \\
\hline Phytoplankton & $3 \times 10^{-3}$ & $2 \times 10^{-2}$ & $3 \times 10^{1}$ & $1 \times 10^{2}$ & $2 \times 10^{2}$ \\
\hline Zooplankton & $1 \times 10^{-3}$ & $3 \times 10^{-2}$ & $3 \times 10^{1}$ & $1 \times 10^{0}$ & $2 \times 10^{0}$ \\
\hline Annelids & 一 & $3 \times 10^{-2, a}$ & & - & $1 \times 10^{0, a}$ \\
\hline Mollusks & $1 \times 10^{-3}$ & $3 \times 10^{-2}$ & $\begin{array}{l}3 \times 10^{1, b} \\
5 \times 10^{1, d}\end{array}$ & $3 \times 10^{0}$ & $2 \times 10^{1}$ \\
\hline Large crustaceans & $2 \times 10^{-3}$ & $3 \times 10^{-2}$ & $\begin{array}{l}3 \times 10^{1, b} \\
1 \times 10^{1, d}\end{array}$ & $3 \times 10^{-1}$ & $5 \times 10^{-1}$ \\
\hline Fish muscle & $4 \times 10^{-3}, \mathrm{e}$ & $1 \times 10^{-1}$ & $\begin{array}{l}2 \times 10^{0, b} \\
1.2 \times 10^{1,}, \mathrm{~d}\end{array}$ & $4 \times 10^{-2}$ & $5 \times 10^{-2}$ \\
\hline Fish liver & 一 & $4 \times 10^{-2, c}$ & $5 \times 10^{2, d}$ & $4 \times 10^{0, c}$ & $1 \times 10^{-1, c}$ \\
\hline Mammal muscle & $1.1 \times 10^{-3, \mathrm{e}}$ & $1 \times 10^{-1, e}$ & $1.7 \times 10^{0, f}$ & $3 \times 10^{-3, e}$ & - \\
\hline Mammal liver & - & $6 \times 10^{-2, g}$ & $2.2 \times 10^{1, f}$ & - & - \\
\hline Marine bird muscle & & $1 \times 10^{-1, e}$ & $3 \times 10^{1, d}$ & $1 \times 10^{-1, e}$ & - \\
\hline $\begin{array}{l}\text { Marine bird liver } \\
\text { Marine bird eggs }\end{array}$ & 一 & $\times 10^{-1}$ to $1 \times 10^{0, e}$ & $4.6 \times 10^{1, d}$ & -2 to $2 \times 10^{0}, \mathrm{e}$ & - \\
\hline
\end{tabular}

a Harrison (1986)

b Aarkrog et al. (1997)

c Noshkin (1985)

d Noshkin (1994)

e IAEA Working Group

f Data from Roos et al. (1992) assuming a dry/wet ratio of 0.2 and a water concentration of $1 \mathrm{~Bq} / \mathrm{m}^{3}$.

g Data from Dahlgaard, personal communication, assuming a water concentration of $6 \mathrm{~Bq} / \mathrm{m}^{3}$. 


\subsection{Estimated and Measured Concentrations of Radionuclides in Marine Species}

Because data on the levels of radionuclides in marine species found in Alaskan waters are extremely limited, few opportunities exist to validate the BCFs selected for use in the risk assessment. There are, however, some measurements for marine organisms collected in the 1960s and $1990 \mathrm{~s}$ for ${ }^{137} \mathrm{Cs}$. Based on the review in Section 3, concentrations of ${ }^{137} \mathrm{Cs}$ were as high as $14 \mathrm{~Bq} / \mathrm{m}^{3}$ in the early 1960s in the Chukchi Sea because of global nuclear fallout, declining to under $2 \mathrm{~Bq} /$ $\mathrm{m}^{3}$ in the 1990s. With a BCF of $0.1 \mathrm{~m}^{3} / \mathrm{kg}$ for the muscle of fish, marine mammals, and seabirds, the levels of ${ }^{137} \mathrm{Cs}$ in muscle would range from about 0.2 to $1.4 \mathrm{~Bq} / \mathrm{kg}$ for species collected during those years. For comparison, Baskaran et al. (1991) reported a concentration of $0.57 \mathrm{~Bq} / \mathrm{kg}$ in muscle tissue of a bowhead whale obtained from the Chukchi Sea in 1987. This value is close to the geometric mean of $0.53 \mathrm{~Bq} / \mathrm{kg}$ calculated from the predicted range of ${ }^{137} \mathrm{Cs}$ concentrations in muscle.

\subsection{SUMMARY}

- The relationship between the radionuclide concentrations in marine species and that in the seawater in which they live is reviewed, and the importance of a derived parameter, bioconcentration factor (BCF), is described. BCF is commonly defined as a unitless parameter providing an indication at steady-state conditions of the bioaccumulation processes resulting from the transfer of radionuclides from ecosystem components (water, particulate matter, and food) to an organism. Information is provided on the principal radionuclides addressed in this assessment, i.e., ${ }^{90} \mathrm{Sr},{ }^{137} \mathrm{Cs},{ }^{241} \mathrm{Am}$, and ${ }^{239} \mathrm{Pu}_{2}$ and for the naturally occurring radionuclide ${ }^{210} \mathrm{Po}$, which may be significant in some risk considerations.

- Bioconcentration factors of radionuclides were demonstrated to have a wide range from one group of organisms to another and from one radionuclide to another. Because the morphology and physiology of organisms may differ greatly, temporally and spatially, this variability is not unexpected. The RAIG constructed log normal probability plots for some radionuclides and characterized this variability in terms of the geometric mean and standard deviations of the BCFs.

- In its data compilation, the RAIG provides recommended BCFs (unitless and in $\mathrm{m}^{3} / \mathrm{kg}$ ) for groups of marine organisms from different trophic levels in Arctic ecosystems. In addition, a more extensive database on BCFs is provided for fishes from both temperate and Arctic waters, for sea mammals, and for seabirds. 


\title{
5. Assessment of Risks to Marine Aquatic Populations Resulting from Exposures to Radionuclides in Arctic Seas
}

\author{
F. Harrison, J. Knezovich, and D. Layton \\ Lawrence Livermore National Laboratory, Livermore, CA
}

$\mathrm{T}$ he RAIG's primary goal in assessing the risks to aquatic populations in the Arctic is to determine whether the concentrations of radionuclides in Arctic waters resulting from potential releases of radionuclides from the FSU are expected to exceed threshold levels of observable effects on the reproductive success of marine organisms. Indications of decreased reproductive success of species are important to decision makers because such decreases may reduce biodiversity, impact endangered species, and change food webs.

A useful way to assess risk is with a tiered approach, each tier progressing to less conservative assumptions and requiring more extensive databases. If, in worst-case scenarios, which include very conservative assumptions (Tier-I assessment), the radionuclide concentrations produce doses or dose rates that are below no-observable-effects levels (NOELs) in the most radiosensitive organisms known, no losses or significant decreases in indigenous species populations are expected in the ecosystems of concern. If they are about equal to or exceed the NOELs, then further assessment is required, and less conservative assumptions are used (Tier-II assessment). If, under TierII assumptions, they are about equal to or exceed the NOELs, then site-specific information and population models in the assessment (Tier III) may be needed. The advantage of a ticred approach is that no expenditures of time, effort, and funds are made until the need is documented.

An aquatic population risk assessment requires (1) knowledge of the basic structure and composition of the ccosystems in the areas of concern, (2) information on the responses of organisms to radiation, (3) data on the quantities of radionuclides that potentially may be present in the organisms and their habitat, and (4) understanding of the impact of internal- and external-emitting radionuclides on their reproductive success. In its consideration, the RAIG will address aquatic species that are important ecologically for maintaining the environment's stability and those that may be endangered. It also considers species that are important economically as well as those that are important in Native cultures. First, the RAIG provides a brief overview of the areas of primary interest in the Arctic and briefly describes the different types of ecosystems (including information on some of the major types of food webs and important species), and ecologically and economically important marine populations at risk. Next, it performs a Tier-I assessment of potential doses to biota. This includes the development of standards for protecting aquatic life. The RAIG defines for radiosensitive species the doses and dose rates resulting in no observable effects on mortality, sterility, or fertility (NOELs). The RAIG then compares these doses and dose 
rates to those that may occur from the FSU radionuclide contamination of the Arctic seas, to those from radionuclides occurring naturally, and to those from fallout radionuclides in the 1960s and 1990s. These comparisons allow the RAIG to draw conclusions about potential detrimental effects of exposures that may occur and those that have occurred in the past.

\subsection{Arctic Marine Ecological Systems}

Arctic marine ecosystems near Alaska and the FSU are very diverse with seasonally fluctuating physical conditions and, in some areas, massive influx of freshwater. An in-depth review of Arctic marine ecosystems is beyond the scope of this report. An overview of some characteristic marine ecosystems is included to provide the reader with an indication of the biological and geographical diversity of the area and of the incompleteness of some of the databases.

The biological diversity of Arctic ecosystems is generally low (Smith, 1990; Becker, 1994; Dayton et al., 1994), and there are large seasonal differences in the number of individuals present of a given species. Compared to similar temperate species, Arctic species usually are longer lived, have higher adult-survival rates, exhibit deferred age of first reproduction in females, and are characterized by a high-lipid content. Many of the species are migratory and are found only in large numbers in certain locales during the breeding season. Because species diversity is low, the ecosystems are potentially more vulnerable to pollution in general. Long-lived species, depending on their reproductive strategy, may be more vulnerable to radioactivity because of the potential for integration of dose in the reproductive organs with time, whereas high-lipid-content species may be more vulnerable to organic contaminants.

A factor critical to determining the distribution of different types of ecosystems and the variability of productivity in space in the Arctic is the mean minimum and maximum extent of the ice and snow cover. If the ice cover is near land or continuous with the land for most of the year, the kinds and numbers of food webs are limited as well as the number of individuals of a given species. Biota appear to respond to the ice cover either by adapting to the conditions physically or metabolically or by migrating from the area during adverse conditions. In general, primary productivity appears to increase with a decrease in latitude in the Arctic.

Various researchers (e.g., Smith, 1990; Codispoti et al., 1991; Becker, 1994; Dayton et al., 1994; and Savinova et al., 1995) have described characteristics of marine ecosystems in the Arctic. Important factors that limit the types of ecosystems are the light regimes, the low mean and extreme temperatures, the changes in permanent ice cover in some areas, and, in other areas, an ice pack fluctuating seasonally. In addition to phytoplankton, an important source of primary production is ice algae. Growth of ice algae is restricted seasonally and spatially and usually precedes that of phytoplankton (Smith, 1990). Because the ice cover, whether permanent or seasonal, thick or thin, with or without a snow layer, affects light penetration, the overall biological productivity in the Arctic is variable, and primary production is coupled to ice conditions. With the melting of the ice cover and increases in light intensity, blooms are initiated and continue as long as conditions are favorable. There is enhanced productivity at the ice edge, and the blooms in the marginal ice-zone area are a qualitatively significant feature (Smith, 1990). Considerable variability in the time of initiation of spring blooms as well as in overall productivity with arca has been reported (Codispoti et al., 1991; Becker, 1994; Dayton et al., 1994; Savinova et al., 1995), and in specific situations where the ice conditions, nutrients, and light duration are appropriate, the productivity may be very high. The overall Arctic primary production rates are now being re- 
vised upwards because better data is available on "new" and total productivity and on the distribution of nutrients (Codispoti et al., 1991). Also affecting the characteristics of the ecosystem in a given area is the magnitude of the runoff from land.

A number of areas in the Arctic may be impacted by radioactivity. Those of special interest in our ecological risk assessment are the Kara Sea and Alaskan Shelf. The Kara Sea is included because it is a potential source of radioactivity and is included in the migratory pathway of some marine mammals and fishes consumed by humans. The Alaskan Shelf is important because the coastal areas are inhabited by populations that rely on the stability of the Alaskan fisheries. Of special concern is the part of the Alaskan Shelf that borders on the Beaufort and Chukchi seas because these areas are predicted to receive greater quantities of radionuclides from the Kara Sea than the coastal areas along the Bering Sea. The coastal zone in each of these areas is extensive and the amount of biological information available about each area is not uniform, in part because of the hostile climate and limited accessibility. For some areas there is only qualitative information and for others in-depth investigations were conducted on specific areas and populations (Grebmeier et al., 1989; Highsmith and Coyle, 1990; Grebmeier and Barry, 1991; Feder et al., 1994).

Arctic marine systems have been classified in different ways. In the overview by Savinova et al. (1995), they quote the work of Zenkevitch (1963) who divided the Arctic into subregions: (1) the abyssal Arctic subregion, (2) the shallow lower Arctic subregion, and (3) the shallow high Arctic subregion. The latter includes all the seas on the shelf of the FSU and North American sector, areas of our special interest. Three areas are contrasted by Grebmeier and Barry (1991) and include (1) the northern Bering and Chukchi seas, (2) the high Arctic Ocean with its marginal seas, and (3) the Arctic shelves influenced by warm Atlantic waters. Using these categories, parts of areas one and two include areas relevant to our risk assessment.

The types of ecosystems in the areas of interest include polar ice, benthic-pelagic, offshore pelagic, and coastal lagoons. In the Kara Sea, the polar-ice type ecosystem dominates with a benthicpelagic type present seasonally; on the Alaskan Shelf along the Beaufort and Chukchi seas, all four types are present; in the Bering Sea, the benthic-pelagic and the offshore pelagic dominate and are relatively productive. It is important to note that even though different geographical areas may have similar types of ecosystems, the food webs and species present within these ecosystems may differ greatly. Appendix A presents information on the Arctic areas of primary interest, on the different types of ecosystems, and on ecologically and economically important marine populations potentially at risk. In addition, Table A-1 provides for the Beaufort and Chukchi seas' shelf areas the types of ecosystems present, some information about the trophic levels present, and a list of some of the species reported for each trophic level. Also, Figures A-1 to A-5 show food webs of important marine mammals. 


\subsection{Tier-I Assessment of Doses to Biota}

\subsubsection{Exposure Pathways of Aquatic Populations}

It is important to consider the transport and fate of radionuclides in ecosystems and how this affects their availability to the biota and the ultimate radiation dose delivered. In this assessment, exposure pathways are taken into consideration, but it is assumed that the radionuclides are totally biologically available. Analysis of the transport and transformation of those radionuclides identified as potentially important in the Arctic and their partitioning among abiotic and biotic components of the ecosystem were considered previously in Sections 3 and 4. For most organisms, especially pelagic organisms, the most important exposure pathway is from radionuclides dissolved in the water column. Because organisms not only swim or are suspended in the water but also ingest or circulate water over respiratory tissues or through their gut, they may receive both internal and external doses and dose rates from radionuclides in the water.

Suspended and deposited particles can be another important source of radionuclides for some organisms. Particle-to-water distribution coefficients for radionuclides may be greater than $10^{4}$, indicating that radionuclides may have a high affinity for particles and that these particles may be an important source of exposure for some organisms. Consequently, for particle feeders, whether pelagic or benthic, considerable radionuclide doses may be received from particles as well as food that is ingested. For benthic particle feeders, exposure from direct contact with the sediments becomcs an important additional route of exposure.

Ingestion of food materials may contribute significantly to radionuclide burdens in biota. For those radionuclides that are transported readily across the gut and assimilated in other tissues, such as ${ }^{137} \mathrm{Cs}$ and ${ }^{90} \mathrm{Sr}$, the contribution to the radionuclide burden from food may be important for dose considerations.

\subsubsection{Dosimetry Models}

Considerable attention has been given to calculation of radiation doses and dose rates to biota. Dosimetry models were reviewed in a recent NCRP report (1991) and UNSCEAR report (1996). In the latter, a dosimetry model was defined as follows: "essentially as a mathematical construction that allows the energy deposition in a defined target to be estimated from a given radionuclide (source) distribution." Considerations included in the models are differences in dose absorbed by the biota because of their shape and size, because of the pathways by which they are exposed to the radioactivity, and because of the energies emitted by the radionuclides. In the dosimetry models, concentrations of radionuclides actually measured in the water, particles, and biota were used as well as those predicted from fate and transport models. In some calculations, steady-state conditions are assumed and bioconcentration factors (BCFs) in the biota and $\mathrm{K}_{d}$ values for the particles are used. Models used to estimate doses and dose rates include CRITR, EXTREM III, BIORAD, and Point Source Dose Distribution (PSDD) (UNSCEAR, 1996). The performance of different models was compared and agreement between CRITR and PSDD was reported to be excellent (NCRP, 1991).

The dosimetry models described above assume the same radiation quality factors (biological effectiveness) for nonhumans as for humans. However, there is still disagreement about the appropriate numbers to be applied to different taxonomic groups. In plants and nonhuman ani- 
mals, the relative biological effectiveness of high-LET alpha particles has not been evaluated, and the use of the human radiation quality factor of 20 was questioned (UNSCEAR, 1996). In humans, the primary concern is with the induction of cancer, a stochastic effect, whereas in domestic and wild flora and fauna, it is the reduced ability to reproduce, a deterministic effect. In mammals, the most generally accepted number is 20 , but values as high as 250 to 360 were reported (Jiang et al., 1994). Because in the PSDD approach a radiation quality factor of 20 was used and the proposed one is 5 (UNSCEAR, 1996), the dose-rate calculations given in subsequent tables for radionuclides emitting alpha particles may be high by a factor of 4 . If a value in the hundreds is accepted for use, however, our dose-rate predictions may be low by a factor of about 10 .

In the past, most of the doses determined for aquatic animals were calculated by one of the dosimetry models described above and primarily for the whole body, even though it is generally understood that the main ecological concern is the dose delivered to the reproductive organs. These types of calculations were made because little information was available on body distribution of radionuclides in aquatic animals. The tissue for which the most information is available is muscle, because this is consumed most frequently by humans. The errors introduced by using doses and dose rates calculated for the whole body instead of for the reproductive organs and early life stages are probably much greater for alpha particles than for beta and gamma emitters. Limited data are available about the transfer of alpha particles across the gastrointestinal tract of nonhumans. Information that would be useful would be the relative concentrations of radionuclides in the muscle tissue to that in the ovary and testis for those species with high radiosensitivity and identified as being critical for population stability.

The RAIG elected the PSDD dosimetry-model approach and used the database developed with that model in this risk assessment. In 1984, Woodhead described a generalized PSDD dosimetry model for bathy/pelagic and benthic fishes, for large bathy/pelagic and benthic crustaceans, for small bathy/pelagic and benthic crustaceans, and for benthic mollusks. (A dosimetry model for primary producers and for mammals was not included). For these seven groups of organisms, he determined the absorbed-dose fraction as a function of energy and considered the contribution to the dose rate from radionuclides dissolved in the water, in suspended and deposited particles, and in food. In a later publication, a generalized set of values per unit water concentration (mSv/ $\mathrm{h}$ per $\mathrm{Bq} / \mathrm{m}^{3}$ ) was derived (IAEA, 1988). These values were calculated for 104 nuclides, were for the same seven groups of organisms, and included external exposure from water and particles and internal exposure from radionuclide incorporation. They used $\mathrm{K}_{\mathrm{d}}$ and $\mathrm{BCF}$ values provided in the IAEA Publication (1985) and the same quality factors as those assumed for humans. The RAIG elected to use the PSDD-dosimetry model approach in this risk assessment and to use the unit-dose-rate conversion factors developed with that model for the radionuclides considered in this risk assessment (Table 5-1). However, because of the UNSCEAR report's recommendation (1996) that the term sievert be restricted to use for humans, the group will refer to the dose rates subsequently as $\mathrm{mGy} / \mathrm{h}$ per $\mathrm{Bq} / \mathrm{m}^{3}$. 
Table 5-1. Unit-dose-rate conversion factors for marine organisms. These factors were determined with the PSDD model and are given as dose rates to a model marine organism resulting from a unit concentration of a given radionuclide in seawater (IAEA, 1988).

\begin{tabular}{|c|c|c|c|c|c|c|}
\hline \multirow{3}{*}{ Model Organism } & & \multicolumn{5}{|c|}{ Radionuclide } \\
\hline & & ${ }^{90} \mathrm{Sr}$ & ${ }^{137} \mathrm{Cs}$ & ${ }^{210} \mathrm{Po}$ & $239,240 \mathrm{Pu}$ & ${ }^{241} \mathrm{Am}$ \\
\hline & & \multicolumn{5}{|c|}{ Unit Dose Rate $\left(\mathrm{mGy} / \mathrm{h}\right.$ per $\left.\mathrm{Bq} / \mathrm{m}^{3}\right)$} \\
\hline \multirow[t]{2}{*}{ Fish } & Bathy! & $1.3 \times 10^{-9}$ & $1.8 \times 10^{-8}$ & $1.2 \times 10^{-4}$ & $2.4 \times 10^{-6}$ & $3.2 \times 10^{-6}$ \\
\hline & Benthic & $1.3 \times 10^{-9}$ & $2.3 \times 10^{-7}$ & $1.2 \times 10^{-4}$ & $2.4 \times 10^{-6}$ & $9.6 \times 10^{-6}$ \\
\hline \multirow[t]{2}{*}{ Large crustacean } & Bathy! & $1.2 \times 10^{-9}$ & $4.7 \times 10^{-9}$ & $3.0 \times 10^{-3}$ & $1.8 \times 10^{-5}$ & $3.2 \times 10^{-5}$ \\
\hline & Benthic & $2.4 \times 10^{-8}$ & $2.5 \times 10^{-7}$ & $3.0 \times 10^{-3}$ & $1.8 \times 10^{-5}$ & $3.9 \times 10^{-5}$ \\
\hline \multirow[t]{2}{*}{ Small crustacean } & Bathy! & $6.5 \times 10^{-10}$ & $3.8 \times 10^{-9}$ & $1.8 \times 10^{-3}$ & $5.9 \times 10^{-5}$ & $1.3 \times 10^{-4}$ \\
\hline & Benthic & $1.1 \times 10^{-7}$ & $2.7 \times 10^{-7}$ & $1.8 \times 10^{-3}$ & $5.9 \times 10^{-5}$ & $1.3 \times 10^{-4}$ \\
\hline Mollusks & Benthic & $5.3 \times 10^{-8}$ & $2.5 \times 10^{-7}$ & $6.1 \times 10^{-4}$ & $1.8 \times 10^{-4}$ & $1.3 \times 10^{-3}$ \\
\hline
\end{tabular}

\subsubsection{Standards for Protection of Aquatic Life}

This assessment will evaluate first the doses and dose rates that were shown to produce significant detrimental effects on organisms and then compare these to the incremental dose rates contributed from the Arctic contamination source terms. Next, it will compare the incremental dose rates to that of an important naturally occurring radionuclide, ${ }^{210} \mathrm{Po}$, and then to that of background radionuclides of the 1960s and 1990s.

Some efforts have been made to define limits to protect aquatic life (IAEA, 1988; NCRP, 1991). The following three ways for evaluating the potential significance of the impact of increased levels of radioactivity on a population were proposed (NRCP, 1991): "(a) the estimated dose rates may be compared with the variation in the natural radiation background, or indeed, the natural background itself; (b) comparisons may be made with the dose rates which have been shown to produce significant detrimental effects on populations of organisms in laboratory or field studies; (c) if, and when, limits are set on the incremental dose rates for the purposes of environmental protection, comparisons may be made against these criteria." 


\subsubsection{Doses and Dose Rates Potentially Producing Significant Detrimental Effects}

It is well documented that radiation induces biological effects through the deposition of energy in the cells of the irradiated individuals (UNSCEAR, 1993 and 1994). These effects are produced from naturally occurring radionuclides as well as those released from anthropogenic activities. Within the cell, damage to the deoxyribonucleic acid (DNA) of the nucleus is of primary concern (Figure 5-1). If the damage from radiation is repaired, no adverse effects are apparent. When DNA repair is defective or the DNA-repair capacity of the cell is exceeded, the damage may be transmitted to the progeny of the cells. If the effects are produced in the somatic cells, they must becomc apparent, by definition, within the life of the irradiated organism and a consequence of concern in humans is the induction of cancer.

If the effects are produced in the germ cells, whose function is to transmit genetic information to new individuals, the effects may be detected in the descendants of the irradiated individual in the first or subsequent generations. Because preserving the health of aquatic environments requires insuring the maintenance of very diverse indigenous populations and the survival of individuals of endangered species, we need to understand the impacts of radiation on reproductive success. The types of databases the RAIG will use to assess current and potential exposures to radioactivity of indigenous populations of organisms are the cffects of irradiation on mortality and on fertility and sterility, important components of reproductive success.

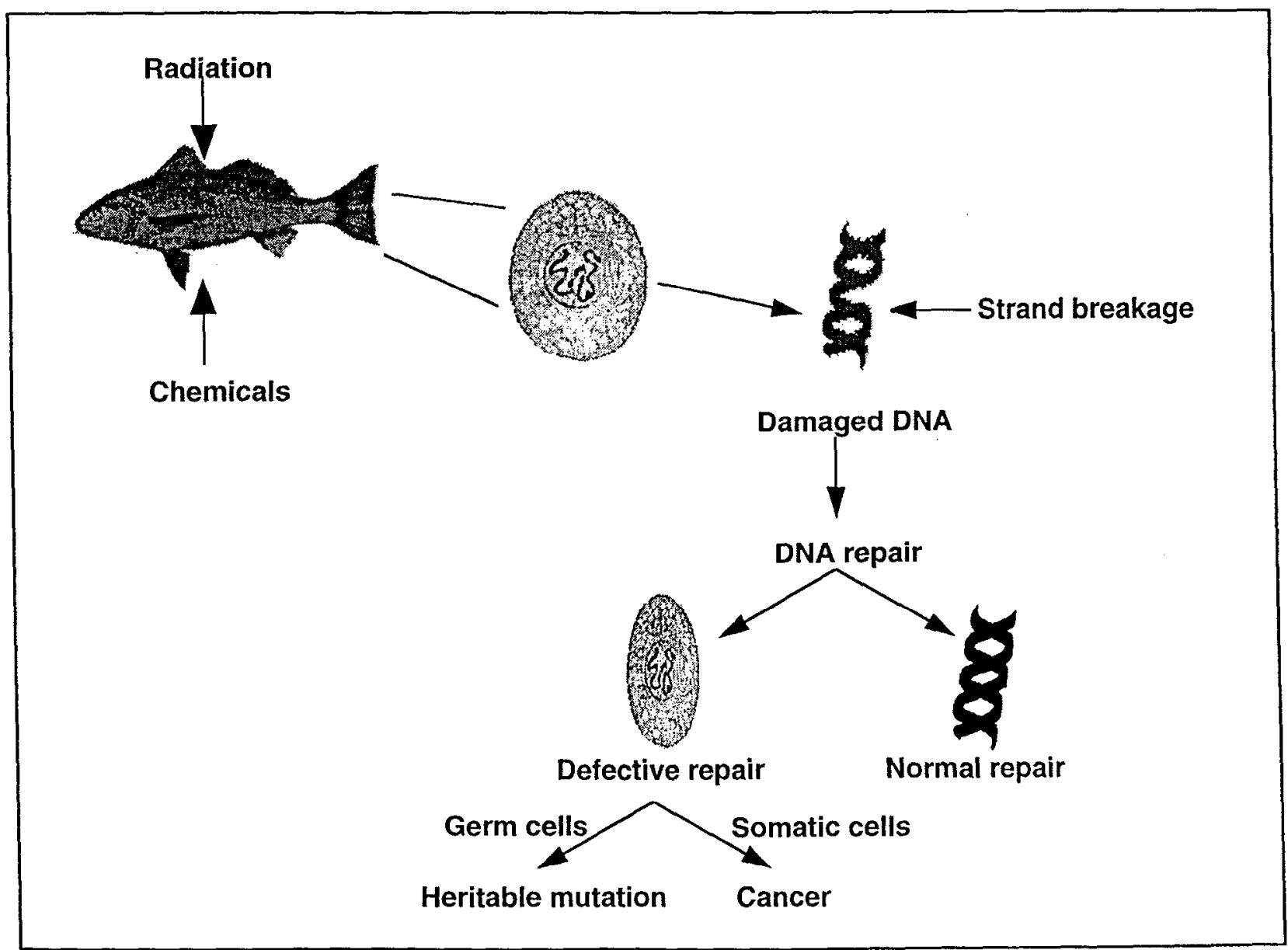

Figure 5-1. Impact of mutagens on genetic material of cells. 
One of the largest databases on radiation effects is that on mortality induced after a single irradiation with relatively high doses. Lethal responses were examined in organisms from different phyla and from different types of ecosystems. In general, there appears to be a relationship between radioresistance to high doses of acute radiation and taxonomy of the organism, primitive forms being more radioresistant than complex vertebrates. Unfortunately, because experiments were carried out under different circumstances and for different time periods, the validity of comparing the results from different taxonomic groups is questionable. However, it is clear that mammals are the most sensitive group. Some representative data on mortality of both vertebrate and invertebrate organisms are presented in Appendix B. For our assessment purposes, the relevant information is that even though the range in the mortality response is large $(<3$ to $>30,000$ Gy) and the ranges in response for different groups of organisms overlap, it appears that doses less than $1 \mathrm{~Gy}$ and dose rates less than $0.1 \mathrm{~Gy} / \mathrm{h}$ will not result in mortality in marine animal groups.

The databases more relevant than those of mortality for ecological risk assessment are those doses and dose rates potentially producing significant detrimental effects on reproductive success. Of primary concern are those irradiation exposures causing sterility and reduced fertility. Data from studies of the effects of acute and chronic exposure on development of gametes and zygotes indicate that, for some fishes and invertebrates, responses at the cellular and molecular levels show effect levels comparable to those observed in some mammals.

Reproductive success for a given population may be related to several characteristics of the species, including the inherent radiosensitivity of its reproductive tissues and early life stages, specific processes occurring during gametogenesis, and its reproductive strategy and life-style (Woodhead, 1984; Anderson and Harrison, 1986; ICRP, 1991; UNCSEAR, 1996). The RAIG considers inherent radiosensitivity factors to be those controlled by the genetic makeup of the organisms and that determine basic developmental processes and pathways and biological-repair processes (see Appendix C). First, it will review the effects of radiation on fertility and sterility, and then briefly describe how different processes of gametogenesis and strategies of reproduction and life style may affect the number of offspring that survive.

Problems encountered when assessing data on the effects of radioactivity on fertility and sterility are the heterogeneity in the kinds of tests performed. It must be reemphasized that factors other than total dose or dose rate affect the results. These include life stage, physiological factors, and exposure conditions. An example of effects of life stage on response in rainbow trout is shown in Table 5-2; early life-history stages appear to be more sensitive than latter stages. Numerous experiments were performed to characterize the responses of gametes and early life stages of fishes to low levels of radiation. Effects on gametes of fishes were reviewed in Egami and Ijiri (1979). In fishes, irradiation not only may retard development but also alter morphological and physiological characteristics of both early life stages and adults. 
Table 5-2. Changes in the radiosensitivity of rainbow trout, Salmo gairdnerii, exposed to acute radiation during development (Welander, 1954; Welander et al., 1949).

\begin{tabular}{lc}
\hline Stage in Life Cycle & LD $_{50}(\mathrm{~Gy})$ \\
\hline Gamete & $0.5-1.0$ \\
1 cell & 0.58 \\
32 cell & 3.1 \\
Germ ring & $4.5-4.6$ \\
Eyed & $4.1-9.0$ \\
Adult & 15 \\
\hline
\end{tabular}

Acute irradiation doses that affect reproduction can be assessed from laboratory data on doses that have resulted in decreased fertility or sterility (Table 5-3). The results demonstrate that effects of acute irradiation on fertility in mammals, fishes, and invertebrates occur from doses ranging over at least two orders of magnitude $(<0.1-20)$ and that doses between $<0.1$ and 0.5 Gy appear to define a critical range in which detrimental effects on fertility are first observed in a variety of radiosensitive organisms, but that doses less than $0.05 \mathrm{~Gy}$ are expected to have no observable effect. Also, induction of sterility occurs over a range from 1 to $1,000 \mathrm{~Gy}$ and doses less than $1 \mathrm{~Gy}$ are expected to have no observable effect. 
Table 5-3. Comparison of sensitivity of reproductive tissues of invertebrates, fishes, and mammals exposed to acute radiation (dose in Gy). The doses for fertility are those at which significant changes were noted and for sterility were for when the effect was noted.

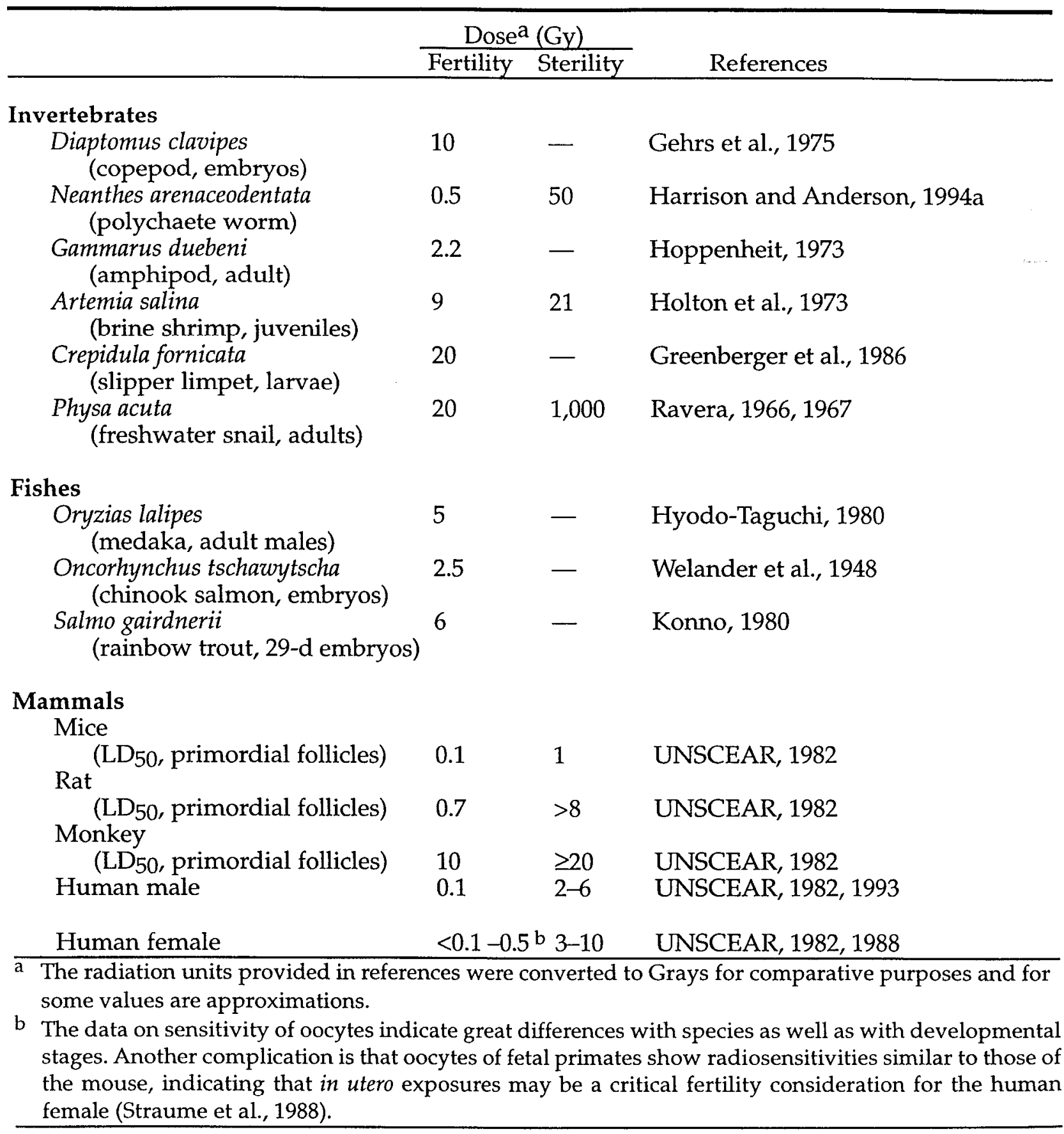


Data on chronic radiation show that the dose rates resulting in significant changes to fertility in invertebrates, fishes, and mammals had a large range of values (Table 5-4). Comparison of the dose rates affecting fertility shows that there is a range of lower values, $0.02-0.2 \mathrm{mGy} / \mathrm{h}$, that result in detectable changes in fertility in both mammals and nonmammalian species, but that dose rates less than $0.2 \mathrm{mGy} / \mathrm{h}$ are expected to have no observable effect. The dose rates known to cause sterility in different species also have a large range, from 0.17 to $1,400 \mathrm{mGy} / \mathrm{h}$, but sterility has not been reported for dose rates less than $0.1 \mathrm{mGy} / \mathrm{h}$.

Table 5-4. Comparison of sensitivity of reproductive tissues of invertebrates, fishes, and mammals exposed chronically to radiation (dose rate in $\mathrm{mGy} / \mathrm{h}$ ). The dose rates for fertility are those at which significant changes were noted and for sterility were for when the effect was noted.

\begin{tabular}{|c|c|c|c|c|}
\hline & Dose Rat & $(\mathrm{mGy} / \mathrm{h})$ & & \\
\hline & Fertility & Sterility & & ences \\
\hline Invertebrates & & & & \\
\hline $\begin{array}{l}\text { Neanthes arenaceodentata } \\
\quad \text { (worm, single generation) }\end{array}$ & 0.19 & 20 & Harrison & Anderson, 1994b \\
\hline $\begin{array}{l}\text { Ophyrotrocha diadema } \\
\text { (worm, seven generations) }\end{array}$ & 3.2 & - & Knowles & Greenwood, 1994 \\
\hline $\begin{array}{l}\text { Daphnia pulex } \\
\quad \text { (water flea, multiple generations) }\end{array}$ & 550 & 1,400 & Marshall & \\
\hline Fishes & & & & \\
\hline $\begin{array}{l}\text { Ameca splendens } \\
\quad(-, \text { single generation })\end{array}$ & $<0.6$ & 0.6 & Woodher & al., 1983 \\
\hline $\begin{array}{l}\text { Poecilia reticulata } \\
\quad \text { (guppy, single generation) }\end{array}$ & 1.7 & 13 & Woodher & 977 \\
\hline $\begin{array}{l}\text { Oryzias lalipes } \\
\text { (medaka, adult males) }\end{array}$ & 2.8 & 840 & Hyodo-T & chi, 1980 \\
\hline $\begin{array}{l}\text { Oncorhynchus tschawytscha } \\
\text { (chinook salmon, embryos) }\end{array}$ & 4.2 & - & Bonham & Donaldson, 1972 \\
\hline Gambusia affinis & 13 & - & Trabalka & Allen, 1977 \\
\hline Mammals & & & & \\
\hline Male human & 0.05 & 0.23 & UNSCEA & $982 ; 1992$ \\
\hline Female human & 0.023 & - & “ & “ \\
\hline Male dog & 0.07 & 0.17 & " " & “ \\
\hline
\end{tabular}


Another factor that differs greatly from species to species is the differences in doses and dose rates that cause sterility and decreased fertility. In the polychaete worm Neanthes arenaceodentata, the difference is two orders of magnitude, whereas for male dogs it is about a factor of two. The database on dose rates resulting in sterility in marine organisms is very limited. The RAIG assumes, however, that induction of sterility in radiosensitive species may occur at dose rates greater than $0.1 \mathrm{mGy} / \mathrm{h}$. Because the database is small, any conclusions about the significance of the difference in dose rates affecting reproduction may not be valid. In a summary of data for mammals (UNSCEAR, 1993), the reader is cautioned that responses are dependent on the developmental stage of the gonadal tissue at the time and duration of the irradiation, and for any species the range in sensitivity may be large. Although such changes in sensitivity are not as well documented in other taxonomic groups, it may be an important factor.

The parameters that are more relevant to protection of ecosystems through limit setting are those values obtained from developmental responses rather than mortality. When comparisons (for the same group of species) are made of the relative radiosensitivity of adults, as measured by mortality, and of the relative radiosensitivity of early stages, as measured by developmental abnormalities or mortality, it is evident that radiosensitivity of early stages as measured by changes during development is not always in the same taxonomic relationship as that of the adult as measured by mortality. Because high radiosensitivity of gonadal tissues and early life stages affects reproductive success directly, radiosensitivity during development is of more concern. Also, the responses of special importance for limit setting are the low values obtained for fertility endpoints because these indicate greater radiosensitivity. It is of interest to note that for invertebrates the low values are in about the same range as those for some fishes and mammals. This indicates that at the cellular and molecular levels, radiosensitivity for these different organisms may not differ much if similar gametogenic stages are exposed.

Reproductive success also is affected significantly by the processes occurring during gametogenesis and their duration. Gametogenesis processes differ greatly from species to species. Important parameters include the ability to repopulate and repair damage to germ cells, the duration and synchrony of stages in gametogenesis, the overall time between production and release of gametes, and the overall time to sexual maturity. Also, within the same species, the responses of male and female gonads are commonly not the same. The testis generally is more radioresistant than the ovary. In some species, sterility requires dose rates and doses to the testis larger than those causing adult mortality. Recovery of gonads from radiation damage may reflect differences between sexes and among species in radioresistance of the stem-cell population and in cells' ability to repopulate.

Reproductive success for a given species may be related also to its reproductive strategy (Woodhead, 1984; Anderson and Harrison, 1986). For example, in a species producing many offspring, the survival of early life stages may be very low, and the loss of abnormal embryos induced from radiation exposure may be masked completely by those lost from other ecological factors, such as food limitation and predation. Species that produce fewer offspring may have strategies for protecting early life stages, such as brooding of the early stages, guarding of nests, and viviparous development (having early life stages develop within the body of the female).

Other important factors of reproductive strategy, in addition to the total number produced, rate of division, and sensitivity of the gametes, include the time between the formation of the primary germ cells and the release of mature gametes. This becomes important in long-lived species, such as whales with a 100-year life span, that are exposed to chronic irradiation, because integration of dose may occur. For some marine mammals and nonmammals, if no repair of radiation damage occurs, the dose to reproductive tissues may be integrated over decades. Unfortunately, in many 
marine mammals, fishes, and invertebrates the processes involved in radiosensitivity and in gametogenic and reproductive strategies are not known.

Reproductive success of a species in natural ecosystems is affected also by the changes in the population gene pool from multigeneration exposures to radiation. In most radioactivity-contaminated ecosystems, the exposure to the biota is chronic and at low levels, resulting in multigeneration exposures. However, the data available on the effects of this type of irradiation on reproductive success are limited. The database from laboratory studies contains information from only two multigeneration studies (Table 5-4). The duration of most studies was less than a complete life cycle, and the stages in the life cycle irradiated were not always comparable. The database from field studies includes results from multigeneration investigations, but the results from many of these studies were confounded by the presence in the ecosystem of contaminants other than radioactivity (NCRP, 1991). The effect of multigeneration exposure becomes important because the dose-response curves for specific species having the same $L_{50}$ may differ greatly (Figure 5-2). One can expect that selection of radioresistant individuals will occur upon continuous exposure, and species having a broader range in sensitivity may have a greater survival potential.

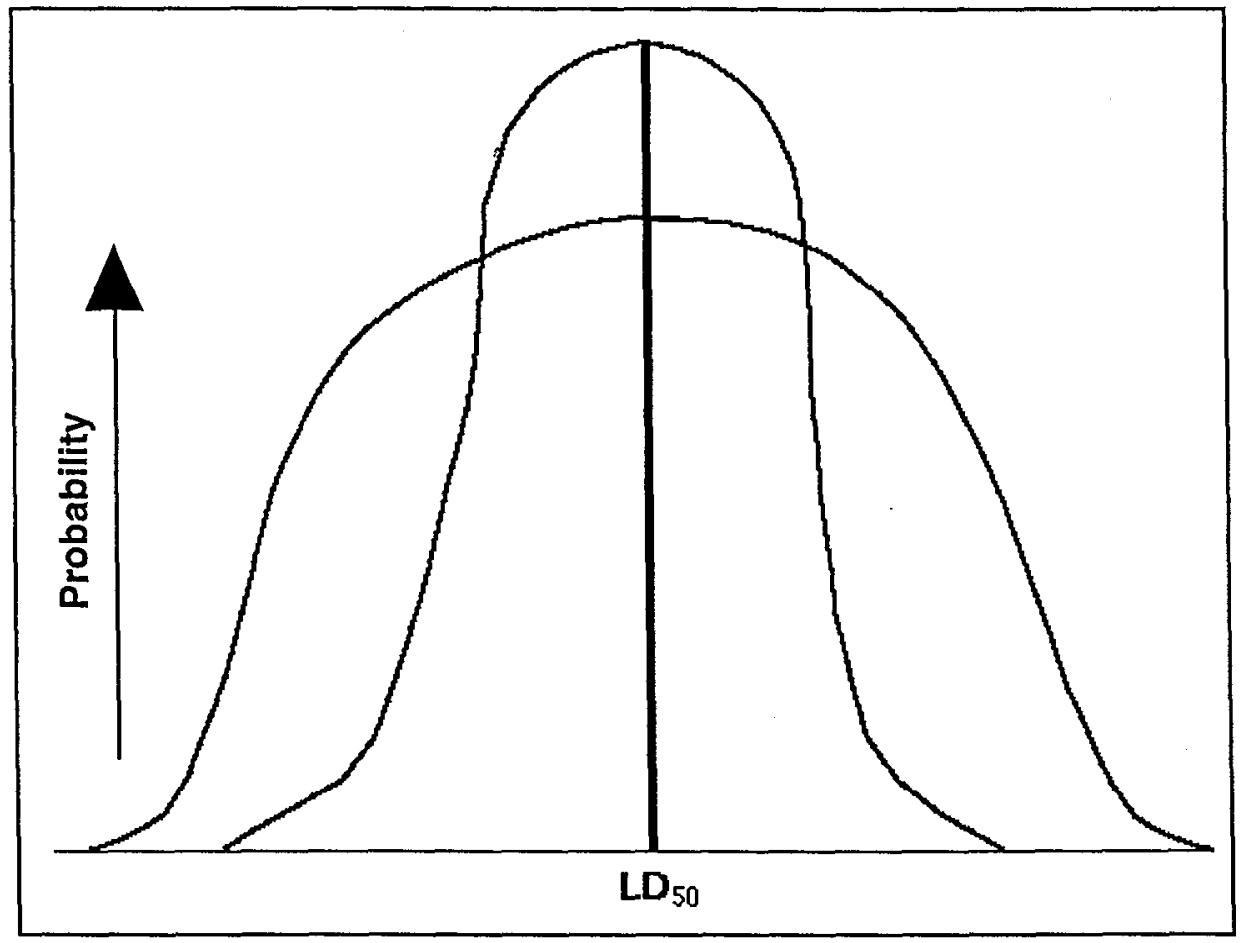

Figure 5-2. For the same $\mathrm{LD}_{50}$ value, the shape of species duse-response curve that occurs from radiation may differ significantly.

\subsubsection{Dose Rates from Potential FSU Radionuclide Contamination of the Arctic Seas}

Dissolved radionuclide concentrations were predicted using the RAIG model for four different scenarios: (1) Kara Sea acute release (instantaneous release and distribution of all known Kara Sea sources), (2) Kara Sea chronic release (predicted time-varying release from Kara Sea source), (3) riverine acute release (instantaneous release and distribution of all known inland sources potentially releasing into the $\mathrm{Ob}$ and Yenisey rivers), and (4) riverine chronic release (predicted gradual release and distribution of all known inland sources potentially releasing into the $\mathrm{Ob}$ 
and Yenisey rivers). The predicted dissolved radionuclide concentrations resulting from these release scenarios were highest in the Beaufort Sea (see Section 3). These concentrations and the unit-dose-rate conversion factors (see Table 5-1) were used to calculate the dose rates for bathy/ pelagic and benthic fishes, large bathy/pelagic and benthic crustaceans, small bathy/pelagic and benthic crustaceans, and benthic mollusks (Table 5-5).

Table 5-5. Dose rates for fish and invertebrates resulting from background and instantaneous releases of radionuclide inventories in the Kara Sea and $\mathrm{Ob}$ and Yenisey rivers. The total doses from anthropogenic radionuclides of concern and from naturally occurring ${ }^{210} \mathrm{Po}$ are provided.

\begin{tabular}{|c|c|c|c|c|c|c|c|}
\hline \multirow[b]{3}{*}{ Organism } & \multirow[b]{3}{*}{ Nuclide } & \multicolumn{6}{|c|}{ Dose Rate $(\mathrm{mGy} / \mathrm{h})$} \\
\hline & & \multicolumn{2}{|c|}{$\begin{array}{c}\text { Background } \\
\text { Radionuclides }\end{array}$} & \multicolumn{2}{|c|}{ Kara Sea Sources } & \multicolumn{2}{|c|}{ Riverine Sources } \\
\hline & & $1960 s$ & $1990 \mathrm{~s}$ & Acute & Chronic & Acute & Chronic \\
\hline \multirow[t]{4}{*}{ Bathy/pelagic fish } & ${ }^{90} \mathrm{Sr}$ & $1.2 \times 10^{-8}$ & $1.3 \times 10^{-9}$ & $3.9 \times 10^{-11}$ & $7.8 \times 10^{-13}$ & $6.0 \times 10^{-11}$ & $2.7 \times 10^{-11}$ \\
\hline & ${ }^{137} \mathrm{Cs}$ & $2.5 \times 10^{-7}$ & $3.6 \times 10^{-8}$ & $5.8 \times 10^{-10}$ & $1.3 \times 10^{-11}$ & $1.4 \times 10^{-11}$ & 0.0 \\
\hline & $239,240 \mathrm{Pu}$ & $1.2 \times 10^{-7}$ & $1.2 \times 10^{-8}$ & $3.8 \times 10^{-10}$ & $1.5 \times 10^{-12}$ & 0.0 & 0.0 \\
\hline & ${ }^{241} \mathrm{Am}$ & $2.9 \times 10^{-8}$ & $3.2 \times 10^{-9}$ & $7.0 \times 10^{-10}$ & $5.8 \times 10^{-13}$ & 0.0 & 0.0 \\
\hline \multirow[t]{2}{*}{ Total anthropogenic } & & $4.1 \times 10^{-7}$ & $5.2 \times 10^{-8}$ & $1.7 \times 10^{-9}$ & $1.6 \times 10^{-11}$ & $7.4 \times 10^{-11}$ & $2.7 \times 10^{-11}$ \\
\hline & ${ }^{210} \mathrm{Po}$ & $1.2 \times 10^{-7}$ & $1.3 \times 10^{-7}$ & $1.3 \times 10^{-7}$ & $1.3 \times 10^{-7}$ & $1.3 \times 10^{-7}$ & $1.3 \times 10^{-7}$ \\
\hline \multirow[t]{4}{*}{ Benthic fish } & ${ }^{90} \mathrm{Sr}$ & $1.2 \times 10^{-8}$ & $1.3 \times 10^{-9}$ & $3.9 \times 10^{-11}$ & $7.8 \times 10^{-13}$ & $6.0 \times 10^{-11}$ & $2.7 \times 10^{-11}$ \\
\hline & ${ }^{137} \mathrm{Cs}$ & $3.2 \times 10^{-6}$ & $4.7 \times 10^{-7}$ & $7.4 \times 10^{-9}$ & $1.6 \times 10^{-10}$ & $1.8 \times 10^{-10}$ & 0.0 \\
\hline & $239,240 \mathrm{Pu}$ & $1.2 \times 10^{-7}$ & $1.2 \times 10^{-8}$ & $3.8 \times 10^{-10}$ & $1.5 \times 10^{-12}$ & 0.0 & 0.0 \\
\hline & ${ }^{241} \mathrm{Am}$ & $8.6 \times 10^{-8}$ & $9.6 \times 10^{-9}$ & $2.1 \times 10^{-9}$ & $1.7 \times 10^{-6}$ & 0.0 & 0.0 \\
\hline \multirow[t]{2}{*}{ Total anthropogenic } & & $3.4 \times 10^{-6}$ & $4.8 \times 10^{-7}$ & $9.9 \times 10^{-9}$ & $1.7 \times 10^{-10}$ & $2.4 \times 10^{-10}$ & $2.7 \times 10^{-11}$ \\
\hline & ${ }^{210} \mathrm{Po}$ & $1.3 \times 10^{-7}$ & $1.3 \times 10^{-7}$ & $1.3 \times 10^{-7}$ & $1.3 \times 10^{-7}$ & $1.3 \times 10^{-7}$ & $1.3 \times 10^{-7}$ \\
\hline \multicolumn{8}{|l|}{ Large bathy/pelagic } \\
\hline \multirow[t]{4}{*}{ crustacean } & ${ }^{90} \mathrm{Sr}$ & $1.1 \times 10^{-8}$ & $1.2 \times 10^{-9}$ & $3.6 \times 10^{-11}$ & $7.2 \times 10^{-13}$ & $5.5 \times 10^{-11}$ & $2.5 \times 10^{-11}$ \\
\hline & ${ }^{137} \mathrm{Cs}$ & $6.6 \times 10^{-8}$ & $9.4 \times 10^{-9}$ & $1.5 \times 10^{-10}$ & $3.3 \times 10^{-12}$ & $3.7 \times 10^{-12}$ & 0.0 \\
\hline & ${ }^{239}, 240 \mathrm{Pu}$ & $9.0 \times 10^{-7}$ & $9.0 \times 10^{-8}$ & $2.9 \times 10^{-9}$ & $1.2 \times 10^{-11}$ & 0.0 & 0.0 \\
\hline & ${ }^{241} \mathrm{Am}$ & $2.9 \times 10^{-7}$ & $3.2 \times 10^{-8}$ & $7.0 \times 10^{-9}$ & $5.8 \times 10^{-12}$ & 0.0 & 0.0 \\
\hline \multirow[t]{2}{*}{ Total anthropogenic } & & $1.3 \times 10^{-6}$ & $1.3 \times 10^{-7}$ & $1.0 \times 10^{-8}$ & $2.1 \times 10^{-11}$ & $5.9 \times 10^{-11}$ & $2.5 \times 10^{-11}$ \\
\hline & ${ }^{210} \mathrm{Po}$ & $3.3 \times 10^{-6}$ & $3.3 \times 10^{-6}$ & $3.3 \times 10^{-6}$ & $3.3 \times 10^{-6}$ & $3.3 \times 10^{-6}$ & $3.3 \times 10^{-6}$ \\
\hline \multicolumn{8}{|l|}{ Large benthic } \\
\hline \multirow[t]{4}{*}{ crustacean } & ${ }^{90} \mathrm{Sr}$ & $2.1 \times 10^{-7}$ & $2.4 \times 10^{-8}$ & $7.2 \times 10^{-10}$ & $1.4 \times 10^{-11}$ & $1.1 \times 10^{-9}$ & $5.0 \times 10^{-10}$ \\
\hline & ${ }^{137} \mathrm{Cs}$ & $3.5 \times 10^{-6}$ & $5.0 \times 10^{-7}$ & $8.0 \times 10^{-9}$ & $1.8 \times 10^{-10}$ & $2.0 \times 10^{-10}$ & 0.0 \\
\hline & $239,240 \mathrm{Pu}$ & $9.0 \times 10^{-7}$ & $9.0 \times 10^{-8}$ & $2.9 \times 10^{-9}$ & $1.2 \times 10^{-11}$ & 0.0 & 0.0 \\
\hline & ${ }^{241} \mathrm{Am}$ & $3.5 \times 10^{-7}$ & $3.9 \times 10^{-8}$ & $8.6 \times 10^{-9}$ & $7.0 \times 10^{-12}$ & 0.0 & 0.0 \\
\hline \multirow[t]{2}{*}{ Total anthropogenic } & & $5.0 \times 10^{-6}$ & $6.5 \times 10^{-7}$ & $2.0 \times 10^{-8}$ & $2.1 \times 10^{-10}$ & $1.3 \times 10^{-9}$ & $5.0 \times 10^{-10}$ \\
\hline & ${ }^{210} \mathrm{Po}$ & $3.3 \times 10^{-6}$ & $3.3 \times 10^{-6}$ & $3.3 \times 10^{-6}$ & $3.3 \times 10^{-6}$ & $3.3 \times 10^{-6}$ & $3.3 \times 10^{-6}$ \\
\hline
\end{tabular}


Table 5-5, continued.

Dose Rate (mGy/h)

\begin{tabular}{|c|c|c|c|c|c|c|c|}
\hline \multirow[b]{3}{*}{ Organism } & \multirow[b]{3}{*}{ Nuclide } & \multicolumn{6}{|c|}{ Dose Rate $(\mathrm{mGy} / \mathrm{h})$} \\
\hline & & \multicolumn{2}{|c|}{$\begin{array}{l}\text { Background } \\
\text { Radionuclides }\end{array}$} & \multicolumn{2}{|c|}{ Kara Sea Sources } & \multicolumn{2}{|c|}{ Riverine Sources } \\
\hline & & $1960 \mathrm{~s}$ & $1990 \mathrm{~s}$ & Acute & Chronic & Acute & Chronic \\
\hline \multirow{4}{*}{$\begin{array}{l}\text { Small bathy/pelagic } \\
\text { crustacean }\end{array}$} & ${ }^{90} \mathrm{Sr}$ & $5.9 \times 10^{-9}$ & $6.5 \times 10^{-10}$ & $2.0 \times 10^{-11}$ & $3.9 \times 10^{-13}$ & $3.0 \times 10^{-11}$ & $1.4 \times 10^{-11}$ \\
\hline & ${ }^{137} \mathrm{Cs}$ & $5.3 \times 10^{-8}$ & $7.6 \times 10^{-9}$ & $1.2 \times 10^{-10}$ & $2.7 \times 10^{-12}$ & $3.0 \times 10^{-12}$ & 0.0 \\
\hline & $239,240 \mathrm{Pu}$ & $3.0 \times 10^{-6}$ & $3.0 \times 10^{-7}$ & $9.5 \times 10^{-9}$ & $3.8 \times 10^{-11}$ & 0.0 & 0.0 \\
\hline & ${ }^{241} \mathrm{Am}$ & $1.1 \times 10^{-6}$ & $1.3 \times 10^{-7}$ & $2.8 \times 10^{-8}$ & $2.3 \times 10^{-11}$ & 0.0 & 0.0 \\
\hline \multirow[t]{2}{*}{ Total anthropogenic } & & $4.2 \times 10^{-6}$ & $4.3 \times 10^{-7}$ & $3.8 \times 10^{-8}$ & $6.4 \times 10^{-11}$ & $3.3 \times 10^{-11}$ & $1 \quad 1.4 \times 10^{-11}$ \\
\hline & ${ }^{210} \mathrm{Po}$ & $2.0 \times 10^{-6}$ & $2.0 \times 10^{-6}$ & $2.0 \times 10^{-6}$ & $2.0 \times 10^{-6}$ & $2.0 \times 10^{-6}$ & $2.0 \times 10^{-6}$ \\
\hline \multicolumn{8}{|l|}{ Small benthic } \\
\hline \multirow[t]{3}{*}{ crustacean } & $\begin{array}{l}{ }^{90} \mathrm{Sr} \\
137_{\mathrm{Cs}}\end{array}$ & $\begin{array}{l}9.9 \times 10^{-7} \\
38 \times 10^{-6}\end{array}$ & $1.1 \times 10^{-7}$ & $3.3 \times 10^{-9}$ & $6.6 \times 10^{-11}$ & $5.1 \times 10^{-9}$ & $2.3 \times 10^{-9}$ \\
\hline & $239,240 \mathrm{Pu}$ & $\begin{array}{l}3.8 \times 10^{-6} \\
3.0 \times 10^{-6}\end{array}$ & $\begin{array}{l}5.4 \times 10^{-7} \\
3.0 \times 10^{-7}\end{array}$ & $\begin{array}{l}8.6 \times 10^{-9} \\
9.5 \times 10^{-9}\end{array}$ & $\begin{array}{l}1.9 \times 10^{-10} \\
3.8 \times 10^{-11}\end{array}$ & $2.1 \times 10^{-10}$ & $\begin{array}{l}0.0 \\
0.0\end{array}$ \\
\hline & $241 \mathrm{Am}$ & $1.2 \times 10^{-6}$ & $1.3 \times 10^{-7}$ & $2.9 \times 10^{-8}$ & $2.3 \times 10^{-11}$ & $1.7 \times 10^{-8}$ & 0.0 \\
\hline \multirow[t]{2}{*}{ Total anthropogenic } & & $8.9 \times 10^{-6}$ & $1.1 \times 10^{-6}$ & $5.0 \times 10^{-8}$ & $3.2 \times 10^{-10}$ & $2.2 \times 10^{-8}$ & $2.3 \times 10^{-9}$ \\
\hline & ${ }^{210} \mathrm{Po}$ & $2.0 \times 10^{-6}$ & $2.0 \times 10^{-6}$ & $2.0 \times 10^{-6}$ & $2.0 \times 10^{-6}$ & $2.0 \times 10^{-6}$ & $2.0 \times 10^{-6}$ \\
\hline \multirow[t]{4}{*}{ Mollusks } & ${ }^{90} \mathrm{Sr}$ & $1.1 \times 10^{-5}$ & $5.3 \times 10^{-8}$ & $1.6 \times 10^{-9}$ & $3.2 \times 10^{-12}$ & $2.4 \times 10^{-9}$ & $1.1 \times 10^{-9}$ \\
\hline & ${ }^{137} \mathrm{Cs}$ & $3.5 \times 10^{-6}$ & $5.0 \times 10^{-7}$ & $8.0 \times 10^{-9}$ & $1.8 \times 10^{-10}$ & $2.0 \times 10^{-10}$ & 0.0 \\
\hline & $239,240 \mathrm{Pu}$ & $9.0 \times 10^{-6}$ & $9.0 \times 10^{-7}$ & $2.9 \times 10^{-8}$ & $1.2 \times 10^{-10}$ & 0.0 & 0.0 \\
\hline & ${ }^{241} \mathrm{Am}$ & $1.2 \times 10^{-5}$ & $1.3 \times 10^{-6}$ & $2.9 \times 10^{-7}$ & $2.3 \times 10^{-10}$ & 0.0 & 0.0 \\
\hline \multirow[t]{2}{*}{ Total anthropogenic } & & $2.5 \times 10^{-5}$ & $2.5 \times 10^{-6}$ & $3.2 \times 10^{-7}$ & $5.6 \times 10^{-10}$ & $2.6 \times 10^{-9}$ & $1.1 \times 10^{-9}$ \\
\hline & $210_{\mathrm{Po}}$ & $6.7 \times 10^{-7}$ & $6.7 \times 10^{-7}$ & $6.7 \times 10^{-7}$ & $6.7 \times 10^{-7}$ & $6.7 \times 10^{-7}$ & $6.7 \times 10^{-7}$ \\
\hline
\end{tabular}

The detrimental effects considered in this risk assessment are the doses and dose rates causing mortality, sterility, and decreased fertility. The database provided above shows that the doses and dose rates affecting these parameters differ widely among the animals examined. In Table 56 , the ranges of doses and dose rates eliciting these responses are presented as well as the noobservable-effects levels (NOELs) that are adopted in this assessment. For purposes of ecological risk assessment, the following assumptions about the potential effects on radiation on marine biota in the Arctic are made: (1) the doses and dose rates causing no observable effects on fertility in the most radiosensitive species will not result in decreased reproductive success in species of invertebrates, fishes, and mammals and (2) doses and dose rates lower than those causing mortality and sterility in the most radiosensitive species will not result in loss of endangered species or reduced biodiversity in Arctic ecosystems. 
Table 5-6. The doses and dose rates resulting in mortality, sterility, and decreased fertility in groups of mammals, fishes, and invertebrates and the recommended no-observable-effects levels (NOELs).

\begin{tabular}{lllll}
\hline & \multicolumn{2}{c}{ Dose (Gy) } & \multicolumn{2}{c}{ Dose Rate $(\mathrm{mG} / \mathrm{h})$} \\
\hline & Range & NOEL & Range & NOEL \\
Mortality & $<3->30,000$ & $<1$ & $0.1-0.48 \quad<0.1$ \\
Sterility & $1-1,000$ & $<1$ & $0.17-1,400<0.1$ \\
Fertility & $<0.1-20$ & 0.05 & $0.023-550 \quad 0.02$ \\
\hline
\end{tabular}

The predicted highest dose rates (for the specific scenarios addressed) were for mollusks living in the Beaufort Sea. It is expected that the highest dose rates would be obtained for mollusks because many live in or on the bottom sediments and may consume organic-rich, radionuclidecontaminated particles. The highest incremental dose rate from FSU-related sources was for mollusks following a hypothetical instantaneous release into the Kara Sea of contained sources. This dose rate was $3.2 \times 10^{-7} \mathrm{mGy} / \mathrm{h}$, which is about five orders of magnitude lower than our dose-rate NOEL for fertility of $2.0 \times 10^{-2} \mathrm{mGy} / \mathrm{h}$. Therefore, this dose rate should not affect adversely the reproductive success of benthic living organisms.

The predicted lowest dose rate from the total incremental FSU radionuclides was $1.70 \times 10^{-9} \mathrm{mGy} /$ $h$, which was calculated for bathy/pelagic fishes in the Beaufort Sea after a predicted instantaneous release into the Kara Sea of known sources. Currently, no data are available on fishes from the Beaufort Sea. However, data on irradiation of salmon eggs and larvae indicate that salmon are relatively radiosensitive (Tables 5-2, 5-3, and 5-4). Because the dose rate predicted for bathy/ pelagic fishes was about seven (7) orders of magnitude lower than our fertility dose-rate NOEL of $2.0 \times 10^{-2} \mathrm{mGy} / \mathrm{h}$, the RAIG proposes that the radiation dose rates predicted for the Beaufort Sea are too low to affect reproductive success of any species of fishes indigenous to or migrating into the Alaskan seas.

No data on irradiation effects on fertility, sterility, and mortality in marine mammals were identified, and no dosimetry models for them are available. However, let us assume that the dosimetry models for humans can be used for these marine mammals and that the food they consume is similar to that of some Alaska Natives, i.e., a mixture of marine fishes and mammals. The RAIG calculated the doses for different Alaskan coastal communities (Table 6-5) for the Kara Sea instantaneous-release scenario and determined dose rates from $1.2 \times 10^{-4}$ to $1.2 \times 10^{-1} \mu \mathrm{Sv} / \mathrm{yr}$ to the Native populations. Let us assume that the marine mammals might receive the highest dose, to $1.2 \times 10^{-1} \mathrm{\mu Sv} / \mathrm{yr}$, or to $1.4 \times 10^{-8} \mathrm{mGy} / \mathrm{h}$, and that they are no more sensitive than the most sensitive mammal tested to date. Then, this dose of to $1.4 \times 10^{-8} \mathrm{mGy} / \mathrm{h}$ assumed for marine mammals is more than 5 orders of magnitude lower than our fertility dose-rate NOEL of $2.0 \times 10^{-2} \mathrm{mGy} / \mathrm{h}$ and should result in no marine-mammal population changes.

Marine birds and their eggs comprise a significant fraction of the diets of some Alaskan indigenous populations. As with marine mammals, no data were identified on radiation effects on seabirds. The limited acute-irradiation data on wild and domestic birds was reviewed (UNSCEAR, 1996), and mortality $\mathrm{LD}_{50} \mathrm{~s}$ were reported to be in the same range as small mammals (5-12 Gy). Chronic irradiation in the range of 8.4 to $42 \mathrm{mGy} / \mathrm{h}$ to field populations of birds caused embryo mortality, and chronic irradiation at dose rates greater than $10 \mathrm{mGy} / \mathrm{h}$ until hatching essentially 
sterilized both sexes of chickens. Because our dose-rate NOEL for fertility of $2.0 \times 10^{-2} \mathrm{mGy} / \mathrm{h}$ is considerably lower than those known to impact bird reproduction, the RAIG concludes that bird populations should suffer no adverse effects.

The response to irradiation of all organisms of most interest to us is effects on fertility. This will be determined not only by dose rate but also on the duration that the species is sexually active. It can be expected that if biological repair is minimal, there is the potential for integration of dose from the time of production of the primary gametocytes to the end of sexual activity. Species of some mollusks, crustaceans, and fishes live as long as 10 years, and most marine mammals have a normal life span of tens of years. Among the species of interest, the one with one of the longest life span is the bowhead whale, which can live as long as 100 years. If worst-case scenarios are assumed, i.e., the dose rate to a female bowhead whale is the maximum for marine species (3.2 $10^{-7} \mathrm{mGy} / \mathrm{h}$ ) for mollusks assuming acute release from Kara Sea sources), there is no biological repair of radiation damage, and the female is sexually active for 50 years, the total dose to the whale is about $1.4 \times 10^{-1} \mathrm{mGy}\left(3.2 \times 10^{-7} \times 8.76 \times 10^{3} \mathrm{~h} / \mathrm{yr} \times 50 \mathrm{yr}\right)$. This total dose more than two orders of magnitude lower than that of the $0.05 \mathrm{~Gy}(50 \mathrm{mGy})$ acute dose affecting fertility in the most sensitive mammal examined.

Migratory patterns may be another factor that affects the exposure of marine species to radioactivity. Again the bowhead whale provides the worst-case exposure. This whale has an extensive migratory range, including most of the Arctic seas. Because it is a planktivorous whale, it has a very short food chain, feeding primarily on phytoplankton and zooplankton. During its migration in the summer to feed in plankton-rich areas in or near the Kara Sea, it may be exposed to waters with higher radionuclide concentrations than those predicted in the Beaufort Sea from acute releases from Kara Sea sources. Thus, until data are available on radionuclide concentrations in the reproductive organs of bowhead whales, considerable uncertainty exists on the actual doses that may be received and the effects that may occur.

\subsubsection{Dose Rates from Radionuclides Occurring Naturally}

Comparing the quantities received from natural sources to those received from anthropogenic sources provides a perspective from which the harmful effects of increased radiation exposure can be considered. Woodhead (1984), who calculated the dose rates to marine organisms from natural background radiation, global fallout, and waste radionuclides, provided such a perspective. The dose rates in the marine environment caused by radionuclide inputs arising from human activities range from less than the natural background exposure for typical nuclear power stations in routine operations up to a few tenths of $\mathrm{mGy} / \mathrm{h}$ for the rather exceptional case of when Windscale was discharging large amounts of waste into the northeast Irish Sea.

The naturally occurring nuclide considered to be the most significant contributor to the dose is ${ }^{210} \mathrm{Po}$ (see Section 4). Comparison of the dose rates to mollusks, which have the highest predicted dose rate, from the total FSU incremental anthropogenic radionuclides to those of ${ }^{210}$ Po shows that the ${ }^{210}$ Po dose rate is more than twice that from the FSU sources, $6.7 \times 10^{-7}$ and $3.2 \times 10^{-7} \mathrm{mGy} /$ $h$, respectively.

Some information is available on the absorbed dose rates from ${ }^{210} \mathrm{Po}$ in specific tissues. For certain pelagic organisms, the dose rate is high, $150 \mathrm{mGy} / \mathrm{h}$ in the hepatopancreas and $4 \mathrm{mGy} / \mathrm{h}$ in the testis of a small mid-water shrimp, and $30 \mathrm{mGy} / \mathrm{h}$ in the intestine and $1 \mathrm{mGy} / \mathrm{h}$ in the gonads of a sardine (UNSCEAR, 1996). 


\subsubsection{Dose Rates from Fallout Radionuclides in the 1960s and 1990s}

The dose rates for the same seven groups of organisms in the Beaufort Sea from background radionuclides existing in the 1960s and 1990s were calculated (Table 5-5). In the 1960s, peak concentrations resulted from nuclear-weapons testing, and the dose rate to mollusks from background radiation was $2.47 \times 10^{-5} \mathrm{mGy} / \mathrm{h}$. This dose rate is about two orders of magnitudes higher than the $3.2 \times 10^{-7} \mathrm{mGy} / \mathrm{h}$ predicted from the hypothetical instantaneous release into the Kara Sea of all contained sources and about three orders of magnitude lower than our dose-rate NOEL for fertility of $2.0 \times 10^{-2} \mathrm{mGy} / \mathrm{h}$ (Table 5-6).

\subsection{UNCERTAINTIES}

\subsubsection{Temperature Effects}

One area of concern is that very little data are available on the effects of the low temperatures in the Arctic on accumulation by and loss of radionuclides from ecologically and economically important Arctic species. From the information available on other biological systems, it is likely that the accumulation and loss of radionuclides will occur at slower rates, but the concentration factors (ratio of the concentration in the organisms to that dissolved in the water at steady-state conditions) will be the same. It also is likely that the amount of radiation damage accumulated will be the same, but its manifestation and repair will occur at lower rates.

\subsubsection{Interaction of Radionuclides with Other Contaminants}

In most marine environments, both organic and inorganic contaminants are present. Yet, little information is available on how these may interact to potentially cause damage. The vast majority of laboratory experiments deal with the effects of contaminants singly. Because our concern is effects of contaminants on fertility and the ultimate effect on the reproductive success of populations, of special interest are the interactions of radiation with those organic contaminants reported to be endocrine disrupters. These are organic contaminants that mimic, block, or disrupt the action of natural reproductive hormones, such as estrogen and testosterone, and are reported to have caused significant reproductive effects in wildlife populations (Hileman, 1996).

\subsection{TIER-II AND TIER-III RISK Assessments}

The radionuclide concentrations predicted from the four hypothetical release scenarios into the Kara Sea from FSU radioactive sources were sufficiently low that the dose rates calculated for the biota in the Beaufort Sea were not likely to affect their reproductive success; they were orders of magnitude lower than the dose rate causing a fertility effect in the most radiosensitive mammalian species. In situations where radionuclide concentrations potentially may impact populations because of reduced reproductive success, however, more in-depth assessments are required. For species potentially at risk, the following types of information may be needed: 
- Radiosensitivity and duration of the different stages of gametogenesis;

- Reproductive strategy and life style;

- Species domain and niche competitors;

- Species resilience and extinction potential; and

- Effects of interactions with other contaminants.

It is not expected that under current regulations there would be releases that would result in dose rates sufficiently high to require either a Tier-II or Tier-III risk assessment. The exceptions might be if information becomes available that interactions among contaminants result in greatly increased adverse effects or if there is a large-scale nuclear accident.

\subsection{SUMMARY}

The RAIG assessed the potential risks to Alaskan marine aquatic populations from exposure to radioactive wastes released into the Arctic seas by the former Soviet Union. This risk assessment considered worst-case scenarios, which include very conservative assumptions (the Tier-I approach). The dosimetry model selected for use was the Point Source Dose Distribution (PSDD) model. This model takes into consideration differences in dose absorbed by biota because of their shape and size, because of the pathways by which they are exposed, and because of the energies emitted by the radionuclides and their bioeffectiveness.

The RAIG evaluated first the doses and dose rates potentially producing significant detrimental effects in radiosensitive organisms. The databases used were the doses and dose rates resulting in mortality and in sterility and decreased fertility, important components of reproductive success. Then, for a group of marine organisms, the dose rates were compared to the dose rates predicted in Alaskan marine biota from (1) the worst-case-scenario release of FSU nuclear wastes in Arctic seas, (2) the important naturally occurring radionuclide, ${ }^{210} \mathrm{Po}$, and (3) the radionuclide levels present in the 1960 s and $1990 \mathrm{~s}$. These comparisons provided a measure of the potential risk to marine populations in Alaskan coastal waters from the release of FSU-nuclear wastes.

Examination of the data on mortality from acute and chronic irradiation shows that it is expected that doses less that $1 \mathrm{~Gy}$ and dose rates less than $0.1 \mathrm{~Gy} / \mathrm{h}$ will not result in mortality of radiosensitive organisms. The RAIG considers the dose of $1 \mathrm{~Gy}$ and the dose rate of $0.1 \mathrm{G} / \mathrm{h}$ to be mortality noobservable-effects levels (NOELs), i.e., the dose and dose rate below which no mortality is observed.

Results from the studies of the effects of acute and chronic irradiation on sterility and fertility indicate that for some fishes and invertebrates, responses at the cellular and molecular levels show effect levels comparable to those observed in some mammals. In radiosensitive species, acute doses greater than $1 \mathrm{~Gy}$ and dose rates greater than $0.1 \mathrm{mGy} / \mathrm{h}$ may induce sterility. The RAIG considers the dose of $1 \mathrm{~Gy}$ and the dose rate of $0.1 \mathrm{G} / \mathrm{h}$ to be sterility NOELs. Also, in radiosensitive vertebrates and nonvertebrates, doses between $<0.1$ and 0.5 Gy and dose rates between 0.02 and $0.2 \mathrm{mGy} / \mathrm{h}$ define a critical range in which detrimental effects on fertility are first observed. Thus, the RAIG considers the dose of $0.05 \mathrm{~Gy}$ and the dose rate of $0.02 \mathrm{mGy} / \mathrm{h}$ to be fertility NOELs. 
The RAIG predicted the highest dose rates from a hypothetical instantaneous release into the Kara Sea of known FSU sources for mollusks living in the Beaufort Sea $\left(3.2 \times 10^{-7} \mathrm{mGy} / \mathrm{h}\right)$. But this dose rate is five orders of magnitude lower than our fertility dose rate NOEL $\left(2.0 \times 10^{-2} \mathrm{mGy} /\right.$ h) and only about half of that $\left(6.7 \times 10^{-7} \mathrm{mGy} / \mathrm{h}\right)$ from naturally occurring ${ }^{210}$ Po present in Alaskan marine systems. Because the dose rates predicted using the worst-case scenario were so low, no Tier-II and Tier-III assessments were made.

The conclusions from this risk assessment are the following.

- The doses and dose rates that cause mortality in marine species are not expected to occur in the Arctic except in the case of future releases associated with large-scale accidents, such as that at Chernobyl.

- The doses and dose rates causing sterility are not expected in the Arctic except in the case of future releases associated with large-scale accidents. Thus, no loss of either human or nonhuman species is expected.

- The doses and dose rates causing no detectable effects on fertility in the most radiosensitive species will not result in deleterious fertility effects in: (1) individual or progeny of marine mammals, such as whales, dolphins, or seals; or (2) the reproductive success of aquatic birds, fishes, and invertebrates. However, the very limited database on doses and dose rates resulting in sterility requires extreme conservation in any Tier-II and Tier-III risk assessment until species-specific information is available.

- An important uncertainty is in the exposures that may not cause sterility but impair fertility to the degree that reproductive success is impacted to the point when the species is not able to compete successfully in the ecosystem.

- The increased resilience of populations to continuous exposure to radioactivity expressed (1) through changes in reproductive strategies, (2) by selection of resistant organisms, and (3) from the up-regulation of genes involved in repair and detoxification is not defined, but such processes would make our results even more conservative.

There is no indication that there will be any decrease or loss in indigenous populations or damage to ecosystems through decreases in biodiversity. However, because our NOELs include no consideration of interactions with other contaminants in the ecosystem or physiological differences resulting from low environmental temperatures, marine biota may be at a greater risk than predicted from just radionuclide contamination. 


\title{
6. Assessment of Risks to Alaskan Populations FROM EXPOSURES TO RADIONUCLIDES IN SubSISTENCE DiETS
}

\author{
B. Napiera, D. Dasherb, and D. Layton ${ }^{\mathrm{c}}$
}

aBattelle Pacific Northwest Laboratories, Richland, WA

bAlaska Department of Environmental Conservation, Fairbanks, AK

CLawrence Livermore National Laboratory, Livermore, CA

7 his section assesses the potential health risks to man of the various sources of nuclear wastes from the FSU addressed in Section 2. The focus of the assessment is on Alaska coastal communities within the area outlined in Figure 6-1. This area contains a linear coastline distance of over $3,200 \mathrm{~km}, 29$ coastal communities, and a population of more than 18,000 people, of which $76 \%$ are native (Alaska Department of Community and Regional Affairs, 1996). Table 6-1 provides population information from the United States 1990 Census on these communities. Residents of the coastal communities obtain large portions of their subsistence foods from the marine environment. Because the consumption of such foods is the principal exposure pathway of concern, the RAIG begins the assessment with a review of data on the intakes of subsistence foods for Alaskan coastal communities. To provide a context for evaluating the results of the dose assessment, the RAIG also provides estimates of the naturally occurring and anthropogenic (man-made) radiation doses associated with the consumption of these marine foods. The team then predicts the doses for various source-term releases of nuclear materials from the Kara Sea, storage ponds at the Mayak and Tomsk nuclear facilities, and dumpsites in the Northwest Pacific. It concludes with analyses of the magnitude of potential risks, key uncertainties, and the benefits of subsistence diets versus potential risks. 


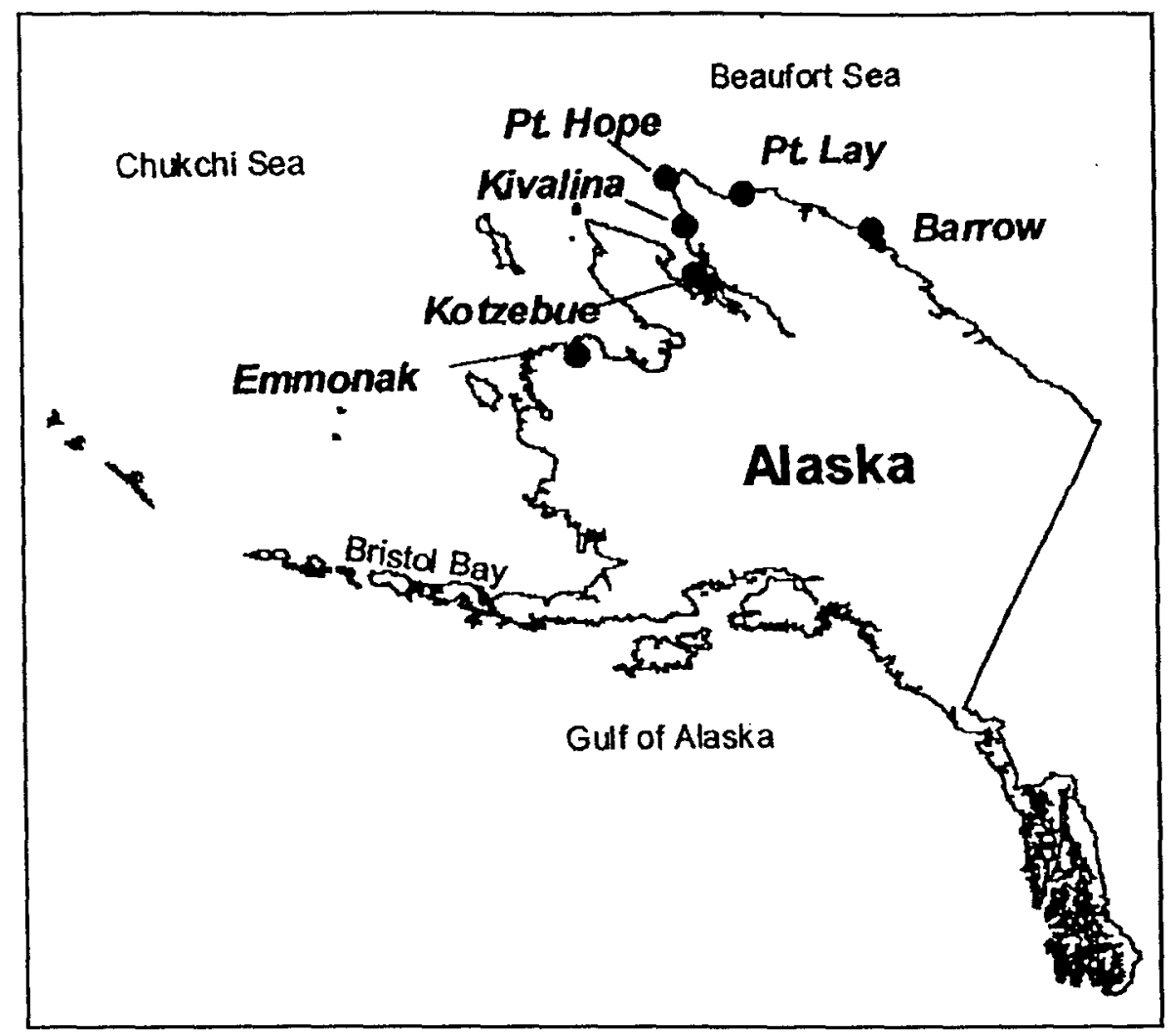

Figure 6-1. Coastal communities of Alaska addressed in the risk assessment of nuclear wastes derived from the former Soviet Union.

\subsection{SUBSISTENCE LIFE-STYLE}

Alaska Native values are centered on their close relationship with the land and sea and its resources. The subsistence-based life-style of Alaska Natives integrates cultural values with hunting, gathering, and processing of local resources. The acquisition of subsistence foods provides a core emotional and spiritual tie within the community that links them with the past and present. For example, whaling activities embody the values of sharing, social relations both within and between communities, leadership, kinship, Arctic survival, and hunting prowess. This holds true for all the other subsistence activities, such as fishing and berry gathering. 
Table 6-1. Census data for coastal communities in Alaska in 1990 (Alaska Dept. of Community and Regional Affairs).

\begin{tabular}{|c|c|c|c|c|c|c|}
\hline Location & Indian & Eskimo & Nleut & $\begin{array}{l}\text { Alaska } \\
\text { Native } \\
\text { Population }\end{array}$ & $\begin{array}{l}\text { Total } \\
\text { Population }\end{array}$ & $\begin{array}{l}\% \\
\text { Alaska } \\
\text { Native } \\
\end{array}$ \\
\hline Barrow & 66 & 2144 & 7 & 2217 & 3,469 & $64 \%$ \\
\hline Buckland & 2 & 300 & 0 & 302 & 318 & $95 \%$ \\
\hline Deering & 1 & 145 & 2 & 148 & 157 & $94 \%$ \\
\hline Diomede & 1 & 163 & 3 & 167 & 178 & $94 \%$ \\
\hline Elim & 0 & 237 & 5 & 242 & 264 & $92 \%$ \\
\hline Emmonak & 8 & 583 & 0 & 591 & 642 & $92 \%$ \\
\hline Gambell & 1 & 504 & 0 & 505 & 525 & $96 \%$ \\
\hline Golovina & 1 & 117 & 0 & 118 & 127 & $93 \%$ \\
\hline Kaktovik & 1 & 186 & 2 & 189 & 224 & $84 \%$ \\
\hline Kivalina & 0 & 309 & 0 & 309 & 317 & $98 \%$ \\
\hline Kotlik & 1 & 441 & 5 & 447 & 461 & $97 \%$ \\
\hline Kotzebue & 44 & 2,017 & 6 & 2067 & 2,751 & $75 \%$ \\
\hline Koyuk & 2 & 216 & 1 & 219 & 231 & $95 \%$ \\
\hline Nome & 68 & 1745 & 11 & 1824 & 3,500 & $52 \%$ \\
\hline Nuiqsut & 1 & 327 & 0 & 328 & 354 & $93 \%$ \\
\hline Pt. Hope & 1 & 585 & 1 & 587 & 639 & $92 \%$ \\
\hline Pt. Lay & 2 & 111 & 0 & 113 & 139 & $81 \%$ \\
\hline Saint Michael & 1 & 268 & 0 & 269 & 295 & $91 \%$ \\
\hline Savoonga & 0 & 493 & 1 & 494 & 519 & $95 \%$ \\
\hline Selawik & 8 & 560 & 1 & 569 & 596 & $96 \%$ \\
\hline Shaktoolik & 0 & 164 & 4 & 168 & 178 & $94 \%$ \\
\hline Shishmaref & 1 & 429 & 1 & 431 & 456 & $95 \%$ \\
\hline Solomon & 0 & 6 & 0 & 6 & 6 & $100 \%$ \\
\hline Stebbins & 2 & 376 & 1 & 379 & 400 & $95 \%$ \\
\hline Teller & 1 & 130 & 0 & 131 & 232 & $87 \%$ \\
\hline Unalakleet & 4 & 574 & 4 & 582 & 714 & $82 \%$ \\
\hline Wainwright & 2 & 462 & 0 & 464 & 492 & $94 \%$ \\
\hline Wales & 0 & 143 & 0 & 143 & 161 & $89 \%$ \\
\hline White Mountain & 2 & 154 & 2 & 158 & 180 & $88 \%$ \\
\hline Totals & 221 & 13,889 & 57 & 14,167 & 18,525 & \\
\hline
\end{tabular}

In the North Slope Borough, $54 \%$ of all households surveyed indicated that half or more than half of the meat, fish, and birds consumed came from subsistence activities (Harcharek, 1995). The same survey indicated that $72 \%$ of Inupiat households obtained half or more of their foods from subsistence harvest, compared with $16 \%$ of the non-Inupiat households. Limited data from the North Slope Borough indicate that the number of Inupiat households reporting that they contain over half of their food from subsistence activities has increased since surveys from 1977 and 1988. Figure 6-2 provides the number of meals per week that contained food from subsistence activities 


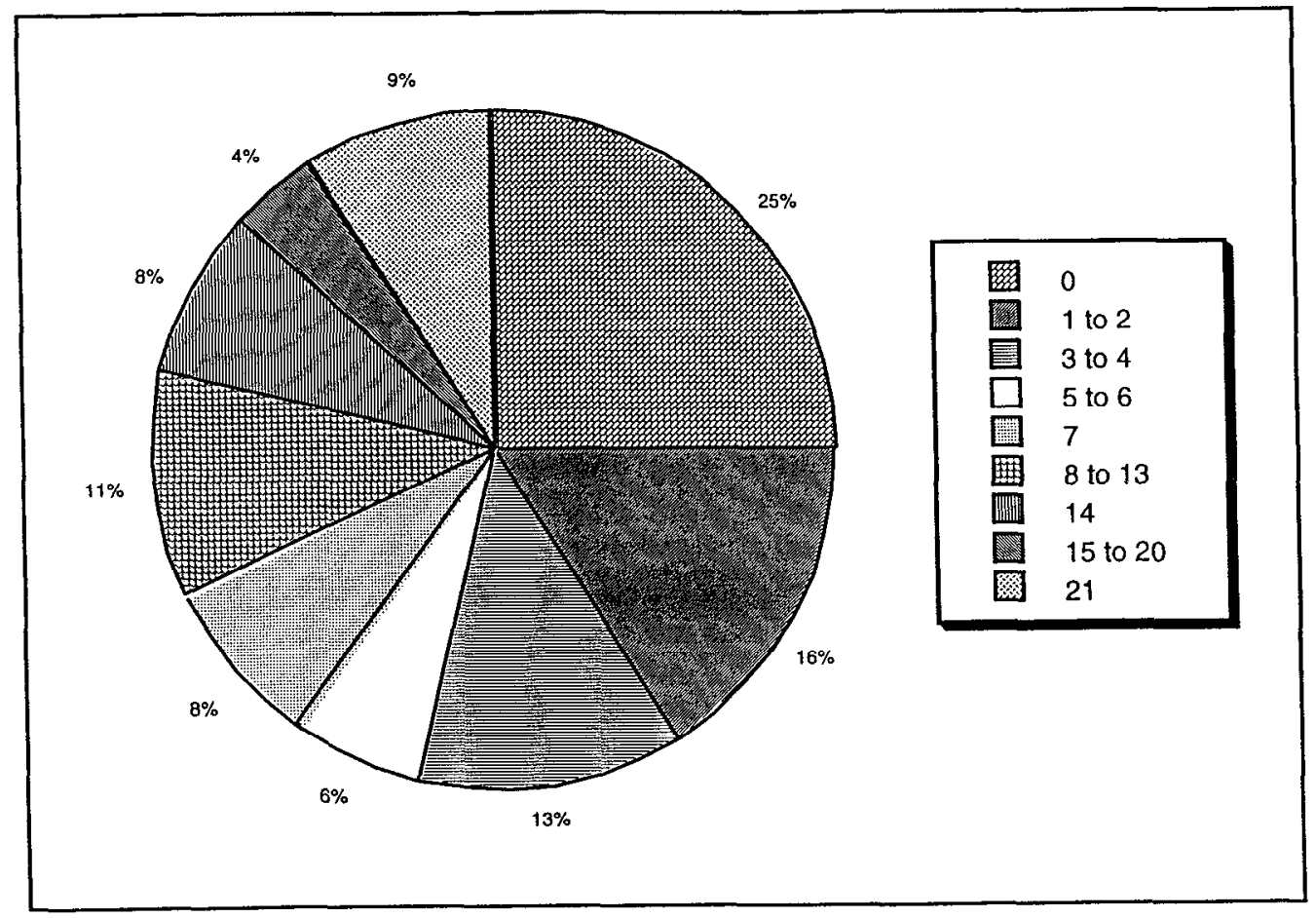

Figure 6-2.

Number of

subsistence-

derived meals

consumed each

week by residents

of the North

Slope Borough in

Alaska.

Figure 6-3.

Number of

subsistencederived meals consumed each week by Point

Lay residents. 
within the North Slope Borough. In some communities the consumption rates increase because of economic and other factors, as shown in Figure 6-3 for Point Lay (Harcharek, 1995).

\subsection{Dietary and Harvest Patterns}

A review of the literature indicates that dietary pattern data for many of these coastal communities were never established, or were collected some time ago. Existing dietary information varies in survey methodology, age groups considered, food descriptions, and composition. Even if consumption rates are known for one locality, the migratory patterns of animals, seasonal climatic conditions, and differences in cultural and economic conditions between communities make it difficult to extrapolate diets between different places and time periods (e.g., historic v. modern). The lack of comprehensive dietary information, including food processing, is a data gap that must eventually be addressed to more accurately estimate radiation exposure and resulting risks to Alaska Natives.

As an alternative technique for developing reference diets of subsistence foods for Alaska Natives in coastal towns and villages, the RAIG has analyzed data on the annual harvesting of marine organisms compiled by the Alaska Department of Fish and Game (ADF\&G), Division of Subsistence, to estimate the per-capita intakes of various subsistence foods (Scott et al., 1995). Harvest information for the coastal communities covers all wild resources harvested for personal and family use, including human and animal consumption, such as by sled-dog teams.

Data on commercial harvests of fish and marine invertebrates are not included. Appendix D summarizes representative per-capita intake rates of food items derived from the communitybased subsistence-harvest surveys. In all cases marine mammals and fish make up the major portion of the marine organisms harvested for these coastal communities. Total marine-resource consumption levels calculated from the harvest data range from 72 to $328 \mathrm{~kg} / \mathrm{yr}$. These fall within marine-resource consumption ranges reported for indigenous populations in Canada (Health Canada, 1995; Kinloch et al., 1992) and for Alaskan coastal villages in the 1960s (Wilimovsky and Wolfe, 1966). Harvest patterns differ among communities because of migratory pathways and seasonal patterns. For example, the harvesting and consumption of fish changes dramatically as one moves from the salmon-rich Yukon Delta area, represented by Emmonak, to the Point Lay community, which relies heavily on a major harvest of beluga whales in the early summer. Although these reference dietary patterns establish a realistic range to assess the radiation dose from the consumption of marine-subsistence foods, they provide no information on the dietary intakes of critical groups who may consume most, if not all, of their foods from local subsistence resources. In addition, the reference diets do not necessarily include unique dietary items, for example, ascidians (also termed sea squirts or tunicates) consumed by residents of St. Lawrence Island in the Bering Sea (Nobmann, 1996).

People are concerned with their own diet patterns and may feel that the representative dietary information does not address their particular situation. The development of data on dose per pound of marine-subsistence food items is used to address this concern. A simplified worksheet for estimating personal doses is provided in Appendix E. An individual concerned about his or her own individual diet could consult with his local health organizations and determine his exposure level. 


\subsection{Reference Diets for Specific Communities}

The ANWAP RAIG model for radionuclide transport identifies three general regions along the Alaska coastline: areas adjacent to the Bering, Chukchi, and Beaufort seas. For the assessment the RAIG team selected villages and towns within each region and established their representative exposures. While these exposures are based on reference diets that may not be completely adequate for any one real person, they provide insight into the overall magnitude and importance of the potential radiation doses received by Alaskan coastal community residents who rely heavily on marine foods. The selected locations are listed below in roughly south-to-north order.

\subsubsection{Emmonak}

With a 1990 population of 642, Emmonak is an Eskimo village involved in commercial fishing, processing, and subsistence activities. It is located at the mouth of the Yukon River on the north bank of Kwiguk Pass in the Yukon-Kuskokwim Delta, 175 miles northwest of Bethel. For the purposes of the RAIG assessment, this settlement is considered to be associated with the waters of the Bering Sea. Residents of Chuloonawick, a nearby summer fish camp, also live in the village. Emmonak has a seasonal economy, with most activity occurring during the summer. It is becoming a center for commercial fishing, purchasing, and processing on the lower Yukon River. Subsistence activities, trapping, and public assistance supplement income. A representative diet for this area is presented here (see Appendix $D$ for details of this diet):

- Fish

- Marine Mammals

- Birds/Eggs

$400 \mathrm{lb} / \mathrm{yr}$

- Marine Invertebrates

$95 \mathrm{lb} / \mathrm{yr}$

$0 \mathrm{lb} / \mathrm{yr}$

$0 \mathrm{lb} / \mathrm{yr}$

\subsubsection{Diomede}

Diomede is located on the west coast of Little Diomede Island in the Bering Strait, 135 miles northwest of Nome. It is only 2.5 miles from Big Diomede Island, Russia, and the international boundary lies between the two islands. Diomede is a traditional Ingalikmiut Eskimo village with a subsistence life-style dependent upon sea mammals, cod, crab, and birds. Its 1990 population was 178. Mainland natives come to Diomede to hunt polar bears. Seal and walrus hides are used to make individual clothing items, parkas, hats, mukluks, and furs and skins for trade. The Diomede villagers depend almost entirely upon a subsistence economy for their livelihood. For the purposes of the RAIG assessment, this settlement is considered to be associated with the waters of the Bering Sea. A representative diet for this area is presented here, based on research conducted in the 1960s (see Appendix D for details of this diet):

- Fish

- Marine Mammals

- Birds/Eggs

- Marine Invertebrates
$30 \mathrm{lb} / \mathrm{yr}$

$715 \mathrm{lb} / \mathrm{yr}$

$137 \mathrm{lb} / \mathrm{yr}$

$20 \mathrm{lb} / \mathrm{yr}$ 


\subsubsection{Kotzebue}

Kotzebue is located on the Baldwin Peninsula in Kotzebue Sound, near the discharges of the Kobuk and Noatak rivers, 26 miles above the Arctic Circle and 549 air miles northeast of Anchorage. The population in 1990 was 2,751, primarily Inupiat Eskimos, and subsistence activities are an integral part of the life-style. As a regional economic center, Kotzebue offers a mixture of government, transportation, and other private-sector businesses. It has a healthy cash economy, a growing private sector, and a variety of public agencies. The majority of income is related directly or indirectly to government spending, the Maniilaq Association, and the Red Dog Mine. Commercial fishing of chum salmon and trout, and processing at Kotzebue Sound Area Fisheries provide some seasonal employment. Most residents rely on subsistence activities to supplement income. For the purposes of the RAIG assessment, this settlement is considered to be associated with the waters of the Chukchi Sea. A representative diet for this area is presented here, based on research conducted in the 1960 s (see Appendix D for details of this diet):

- Fish

- Marine Mammals

- Birds/Eggs

- Marine Invertebrates
$16 \mathrm{lb} / \mathrm{yr}$

$216 \mathrm{lb} / \mathrm{yr}$

$77 \mathrm{lb} / \mathrm{yr}$

$0 \mathrm{lb} / \mathrm{yr}$

\subsubsection{Kivalina}

Kivalina is situated at the tip of an 8-mile barrier reef located between the Chukchi Sea and Kivalina Lagoon. Its 1990 population was 317. Kivalina is a traditional Eskimo village where subsistence activities, including whaling, provide most food sources. For the purposes of the RAIG assessment, this settlement is considered to be associated with the waters of the Chukchi Sea. A representative diet for this area is presented here (see Appendix D for details of this diet):

- Fish

- Marine Mammals

- Birds/Eggs

- Marine Invertebrates
$234 \mathrm{lb} / \mathrm{yr}$

$487 \mathrm{lb} / \mathrm{yr}$

$3 \mathrm{lb} / \mathrm{yr}$

$0.1 \mathrm{lb} / \mathrm{yr}$

\subsubsection{Point Hope}

The community of Point Hope, in the North Slope Borough, is located near the tip of Point Hope Peninsula, a large gravel spit that forms the westernmost extension of the northwest Alaska coast, 330 miles southwest of Barrow. A traditional Inupiat Eskimo village dependent upon subsistence activities, Point Hope's 1990 population was 639. For the purposes of the RAIG assessment, this settlement is considered to be associated with the waters of the Chukchi Sea. A representative diet for this area is presented here, based on research conducted in the 1960s (see Appendix D for details of this diet):

- Fish

- Marine Mammals

- Birds/Eggs

- Marine Invertebrates
$187 \mathrm{lb} / \mathrm{yr}$

$394 \mathrm{lb} / \mathrm{yr}$

$124 \mathrm{lb} / \mathrm{yr}$

$0 \mathrm{lb} / \mathrm{yr}$ 


\subsubsection{Point Lay}

The community of Point Lay is an unincorporated village in the North Slope Borough. Located near the mouth of the Kokolik River, about 300 miles southwest of Barrow, Point Lay is a traditional Inupiat Eskimo village, with a dependence upon subsistence activities and a 1990 population of 139. For the purposes of the RAIG assessment, this settlement is considered to be associated with the waters of the Chukchi Sea. A representative diet for this area is presented here (see Appendix $\mathrm{D}$ for details of this diet):

- Fish

- Marine Mammals

- Birds/Eggs

- Marine Invertebrates
$25 \mathrm{lb} / \mathrm{yr}$

$637 \mathrm{lb} / \mathrm{yr}$

$18 \mathrm{lb} / \mathrm{yr}$

$0 \mathrm{lb} / \mathrm{yr}$

\subsubsection{Barrow}

Barrow is situated on the Chukchi Sea coast, 10 miles south of Point Barrow from which it takes its name. It is the economic center of the North Slope Borough, the city's primary employer, and numerous businesses provide support services to oil-field operations. The majority of Barrow's 3,500 residents are Inupiat Eskimos who have traditionally depended on subsistence marine mammal hunting, supplemented by inland hunting and fishing. Marine mammal hunts and other subsistence practices are an active part of their culture. Although technically still within the Chukchi Sea, this point is the dividing line between the RAIG model's Chukchi and Beaufort calculational zones. For this assessment, the ocean water offshore of Barrow is assumed to be best represented by the Beaufort box. Two representative diets for this area are presented here, one for current conditions and one as described in the 1960s; (see Appendix D for details of these diets):

\section{Current Diet}

$27 \mathrm{lb} / \mathrm{yr}$

- Fish

- Marine Mammals

- Birds/Eggs

- Marine Invertebrates
$128 \mathrm{lb} / \mathrm{yr}$

$3 \mathrm{lb} / \mathrm{yr}$

$0 \mathrm{lb} / \mathrm{yr}$

\section{0s Diet}

$110 \mathrm{lb} / \mathrm{yr}$

$183 \mathrm{lb} / \mathrm{yr}$

$48 \mathrm{lb} / \mathrm{yr}$

$0 \mathrm{lb} / \mathrm{yr}$

\subsubsection{Eastern North Slope Villages}

Relatively few people live along the coast to the east of Barrow. This area is considered to be represented by the concentrations of radionuclides in the Beaufort Sea. Exposure and dietary patterns for residents of this area are taken to be similar to those defined for Canadian residents of the far north (Hcalth Canada, 1995). A representative diet for this area is presented here (see Appendix $D$ for details of this diet):

- Fish

- Marine Mammals

- Birds/Eggs

- Marine Invertebrates
$187 \mathrm{lb} / \mathrm{yr}$

$858 \mathrm{lb} / \mathrm{yr}$

$0 \mathrm{lb} / \mathrm{yr}$

$0 \mathrm{lb} / \mathrm{yr}$ 


\subsection{Current and Historical Doses from Natural and Back- GROUND SOURCES}

Radiation is a natural part of the earth's environment. It comes from the sky above us, the earth beneath us, and even from our own bodies. The air we breathe and the food we eat contain some natural radioactivity. In fact, the average person in the United States receives a radiation dose of about 3,000 microsievert ( $\mu \mathrm{Sv}$ ) per year from natural sources compared to a dose of about $500 \mu \mathrm{Sv}$ per year from "man-made" sources, including medical X-rays.

\subsubsection{Radioactive Materials in Rocks and Soil}

Natural radioactive material in rocks and soil account for about $280 \mu \mathrm{Sv}$, or $8 \%$ of the radiation dose the average person receives in a year. The earth's crust contains small amounts of uranium and thorium as well as a radioactive isotope of potassium. The radiation dose to people comes directly from the rocks and soil and from building materials that come from the earth such as bricks and concrete. Small amounts of radon, a radioactive gas that comes from the radioactive decay of uranium, seep into the atmosphere from the soil. On average, radon in homes and other buildings in the continental United States accounts for 2,000 $\mathrm{SSv}$ per year, or about $55 \%$ of the total radiation dose an individual receives in a year from all sources, including medical X-rays. Radon, however, is not expected to be an important source of background dose for people living in coastal Arctic communities, because it can not easily diffuse out of frozen soils.

\subsubsection{Radioactive Materials in the Body}

About $11 \%(400 \mu \mathrm{Sv})$ of the radiation dose the average person receives comes from naturally occurring radioactive materials in the body. Radioactive isotopes of potassium and polonium, as well as other radioactive materials that occur naturally in air, water, and soil, are incorporated into the food we eat and then into our body tissues. This is the type of exposure this assessment addresses. Doses to northern peoples from natural polonium sources such as caribou (Thomas, Sheard, and Swanson, 1994) and seafoods (see subsection 6.4.4 below), are somewhat higher than the national average.

\subsubsection{Cosmic Rays}

Cosmic radiation comes from outer space. The radiation dose from cosmic radiation increases with altitude, roughly doubling every 6,000 feet. A resident of Florida (at sea level), therefore, receives $260 \mu \mathrm{Sv}$ per year from cosmic radiation while a resident of Denver, Colorado, which is a mile high, receives a dose of $500 \mu \mathrm{Sv}$ per year. Residents of Leadville, Colorado (about 2 miles above sea level) receive about $1,250 \mu \mathrm{Sv}$ per year from cosmic radiation. A passenger in a jetliner traveling at 37,000 feet receives about 60 times as much dose from cosmic radiation as a person at sea level.

The cosmic radiation background also varies slightly with latitude. Lower-energy charged prides are defected back into space as a result of the influence of the earth's magnetic field. The geomagnetic cusp at northern latitudes allows a greater flux of low-energy protons to reach the top of the earth's atmosphere, slightly increasing the ionization and generation of secondary particles. At 
sea level, this results in an increase in the cosmic radiation background at high latitudes of about $10 \%$ over its value at the equator (UNSCEAR 1993). Thus, a northern Alaska resident might receive about $285 \mu \mathrm{Sv} / \mathrm{yr}$ from this source, compared to the $260 \mu \mathrm{Sv} / \mathrm{yr}$ to a Florida resident.

The average dose from natural background radiation varies across the country from $2,500 \mu \mathrm{Sv} / \mathrm{yr}$ on the coasts to 5,000 to 6,000 $\mu \mathrm{Sv} / \mathrm{yr}$ in the Rocky Mountain West. Background doses to residents of coastal Alaska are expected to be near the lower end of this range, about 2,500 $\mu \mathrm{Sv} / \mathrm{yr}$, primarily because of the lower dose from radon.

\subsubsection{Internal Doses from Natural Radioactivity in Seafoods}

Seafoods provide one source of radioactive materials taken into the body. Fish, mammals, birds and eggs, and shellfish eaten by Alaska residents all contain radionuclides from both natural and existing man-made sources. Foods derived from the ocean all have relatively high concentrations of ${ }^{210} \mathrm{Po}$, the radionuclide that provides most of the dose to people from natural sources. Depending on how much of these types of foods one eats, the fraction of the total dose received from internal sources may be larger or smaller. Table 6-2 presents estimates of the annual background dose for each reference diet described above. These dose rates have remained essentially constant for many thousands of years, and will remain so into the distant future, because the source is the continuing decay of materials that make up the earth itself.

It should be noted that the individual dose rate conversion factor (the quantity that converts intake to radiation dose) for ${ }^{210} \mathrm{Po}$ is itself somewhat uncertain. The uptake of polonium from the gastrointestinal tract has been shown to vary from a few percent to as high as $80 \%$. This, combined with lack of knowledge about the actual behavior of polonium in the human body, results in an uncertainty of at least a factor of 3 around the recommended value. The International Commission on Radiological Protection has recently raised the recommended value by about a factor of 2 to partially account for these difficulties (ICRP, 1994). Recent studies involving residents of northern Canada indicate that the dose-conversion factor could be even higher (Thomas, 1994; Health Canada, 1995).

Table 6-2. Background doses resulting from the ingestion of ${ }^{210} \mathrm{Po}$ in seafoods.

\section{Food Source}

\begin{tabular}{|c|c|c|c|c|c|}
\hline Location/Diet & Fish & Mammals & $\begin{array}{l}\text { Birds/Eggs } \\
\text { Dose, } \mu \text { Sv /yr }\end{array}$ & Invertebrates & Totals \\
\hline Barrow & $\overline{13}$ & 54 & 22 & 0 & 90 \\
\hline Barrow 1960s Diet & 55 & 77 & 356 & 0 & 488 \\
\hline Canadian Diet & 92 & 361 & 0 & 0 & 453 \\
\hline Emmonak & 198 & 40 & 0 & 0 & 238 \\
\hline Diomede 1960s Diet & 15 & 301 & 1,014 & 145 & 1,474 \\
\hline Kivalina & 116 & 205 & 22 & 1 & 344 \\
\hline Pt. Lay & 12 & 268 & 131 & 0 & 411 \\
\hline Kotzebue 1960 s & 8 & 91 & 568 & 0 & 667 \\
\hline Pt. Hope $1960 \mathrm{~s}$ & 93 & 166 & 919 & 0 & 1,177 \\
\hline
\end{tabular}




\subsubsection{Internal Doses from Historical Man-Made Sources}

Just as seafoods contain naturally occurring radionuclides, they also now contain radionuclides from past human activities, primarily fallout from the testing of atomic bombs in the 1950s and 1960s, and from the fallout after the accident at the Chernobyl nuclear-power plant. The primary radionuclide contributing these doses is ${ }^{137} \mathrm{Cs}$. As with the natural radionuclides, the amount of foods eaten controls how large the dose is from this source. Doses from consuming ${ }^{137} \mathrm{Cs}$ in subsistence foods have been larger in the past, peaking in the 1960s during the period of atmospheric testing of nuclear weapons (see Table 6-3). Current dose rates associated with man-made radionuclides in the Arctic presented in Table 6-4 are much lower than previous dose rates and are about one-tenth of the historical peak values from the 1960s. The doses from fallout radionuclides are decreasing slowly and will continue to do so unless new sources are introduced.

Table 6-3. Doses associated with the consumption of seafoods during the 1960 s that contain ${ }^{241} \mathrm{Am}$, ${ }^{137} \mathrm{Cs},{ }^{239} \mathrm{Pu}$, and ${ }^{90} \mathrm{Sr}$ present in Arctic waters as a result of nuclear fallout from weapons testing.

\begin{tabular}{|c|c|c|c|c|c|}
\hline \multirow[b]{2}{*}{ Location/Diet } & \multicolumn{4}{|c|}{ Food Source } & \multirow[b]{2}{*}{ Totals } \\
\hline & Fish & Mammals & $\begin{array}{l}\text { Birds / Eggs } \\
\text { Dose, } \mu S v / y r\end{array}$ & Invertebrates & \\
\hline Barrow & $0 . \overline{3}$ & 1.1 & 0.1 & 0.0 & 1.5 \\
\hline Barrow 1960s Diet & 1.1 & 1.6 & 0.9 & 0.0 & 3.6 \\
\hline Canadian Diet & 1.8 & 7.7 & 0.0 & 0.0 & 9.5 \\
\hline Emmonak & 3.8 & 0.8 & 0.0 & 0.0 & 4.7 \\
\hline Diomede 1960s Diet & 0.3 & 6.4 & 2.5 & 0.7 & 9.9 \\
\hline Kivalina & 2.2 & 4.4 & 0.1 & 0.0 & 6.7 \\
\hline Pt. Lay & 0.2 & 5.7 & 0.3 & 0.0 & 6.3 \\
\hline Kotzebue 1960s & 0.2 & 1.9 & 1.4 & 0.0 & 3.5 \\
\hline Pt. Hope 1960s & 1.8 & 3.5 & 2.3 & 0.0 & 7.6 \\
\hline
\end{tabular}

\subsection{Projected Doses from Russian Nuclear Sources}

The principal nuclear source terms addressed in this assessment are reactor-related wastes disposed of in the Kara Sea and radioactive liquid wastes stored at inland locations adjacent to the $\mathrm{Ob}$ and Yenisey rivers. To assess the potential magnitude of the risks such sources pose, the RAIG developed two basic types of scenarios, one describing accidental or acute discharges of nuclides and the other time-varying or chronic discharges (Section 2). To facilitate comparisons of the various source-term scenarios, the RAIG assesses the peak doses for each scenario. 
Table 6-4. Doses associated with the consumption of seafoods during the 1990s that contain ${ }^{241} \mathrm{Am}$, ${ }^{137} \mathrm{Cs},{ }^{239} \mathrm{Pu}$, and ${ }^{90} \mathrm{Sr}$ present in Arctic waters as a result of nuclear fallout from weapons testing.

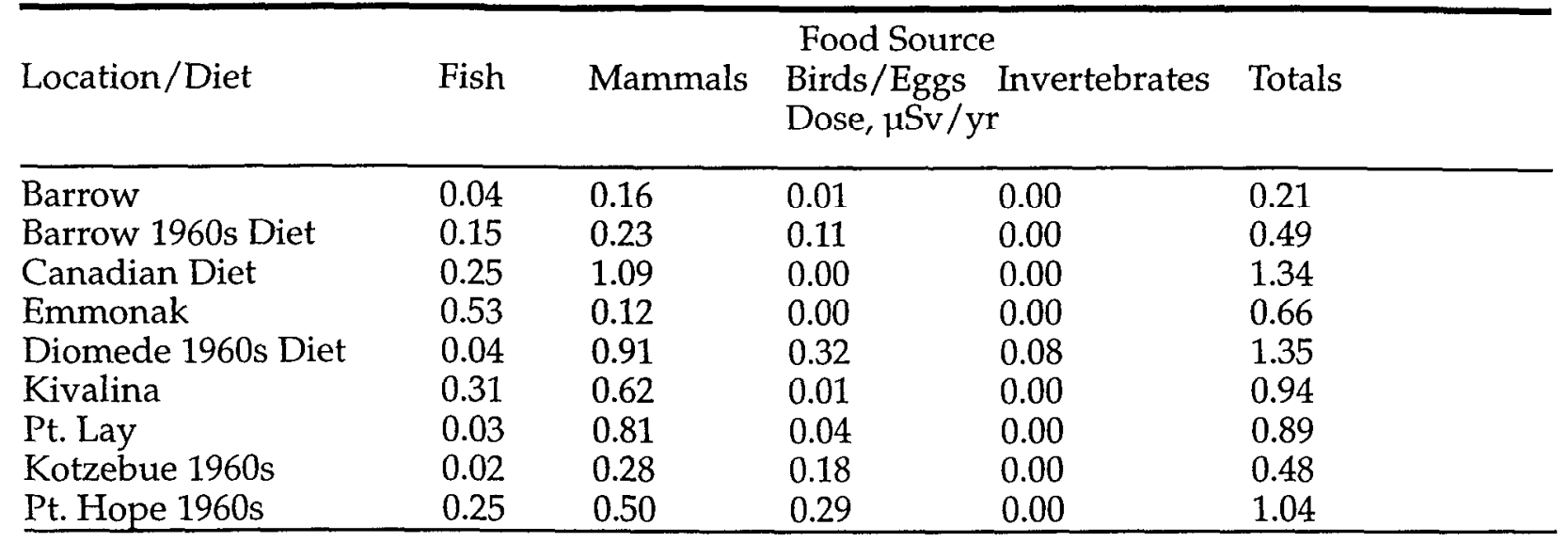

\subsubsection{Doses Derived from Nuclear Materials Disposed of in the Kara Sea}

Reactor components and other radioactive materials, as described in Section 2, were dumped into the Kara Sea, primarily in the vicinity of the island of Novaya Zemlya. The RAIG model helped simulate the transport of these materials to the coasts of Alaska (Section 3), and the BCFs described in Section 4 helped estimate the concentrations of radionuclides in foods that Alaskans might eat. The models predict that, for an instantaneous release of the entire inventory of all radionuclides from the dumped wastes into the ocean water, the highest concentrations will occur in about 10 years. The potential doses to people living in the selected communities are provided in Table 6-5 for the acute, or instantaneous, release and for the time-varying release of nuclides from the Kara Sea sources. The radionuclide providing the largest portion of the dose is ${ }^{137} \mathrm{Cs}$, for all pathways except shellfish (marine invertebrates). For the filter-feeding shellfish, the long-lived actinides ${ }^{239} \mathrm{Pu}$ and ${ }^{241} \mathrm{Am}$ represent a major contribution. However, because shellfish are not major portions of the diet in any of the Alaskan locations, the actinides constitute no significant contributor to the overall doses. The models indicate that the dose rates along the Alaska coast will decrease with time after the initial peak (Section 3 ). This reduction is caused by radioactive decay of the primary radionuclides, ${ }^{137} \mathrm{Cs}$ and ${ }^{90} \mathrm{Sr}$, by loss of these and other radionuclides into sediments in the deep waters, and by dilution of the radionuclides into waters of the North Atlantic Ocean. The time-varying release of nuclides, controlled by the corrosion-based discharge of nuclides to the Kara Sea, results in predicted doses for the Beaufort and Chukchi Sea coastal locations that are approximately 100 times lower than the instantaneous case. The predicted doses for the more realistic time-varying release of the Kara Sea sources are well below the doses associated with ${ }^{210} \mathrm{Po}$ (Table 6-2) and with fallout nuclides present in Alaskan waters during the 1960s and 1990s (i.e., Tables 6-3 and 6-4).

As an example of the dose calculations, consider the dose to an individual in Barrow from consuming fish contaminated with ${ }^{137} \mathrm{Cs}$ from the expected time-varying release in the Kara Sea. From Figure 3-9, the peak concentration in the Beaufort Sea adjacent to Barrow will be $7.1 \times 10^{-4}$ $\mathrm{Bq} / \mathrm{m}^{3}$ in the year 2080 . From Table $4-7$, the BCF for cesium in fish is $0.1 \mathrm{~m}^{3} / \mathrm{kg}$. From Table $2-11$, the dose-conversion factor for cesium is $1.4 \times 10^{-8} \mathrm{~Sv} / \mathrm{Bq}$. As discussed in this section, an esti- 
Table 6-5. Summary of the doses predicted for different Alaskan coastal communities, diets, and release scenarios for FSU nuclear wastes.

\begin{tabular}{|c|c|c|c|c|c|c|c|c|c|}
\hline \multirow[t]{2}{*}{ Food/Scenario } & Barrow & Barrow $60 s^{a}$ & Canadian (Beak) & Emmonak & $\begin{array}{c}\text { Location } \\
\text { Diomede } 60 \mathrm{~s}^{\mathrm{a}}\end{array}$ & Kivalina & Pt. Lay & Kotzebue $60 \mathrm{~s}^{\mathrm{a}}$ & $\begin{array}{c}\text { Pt. Hope } \\
60 \mathrm{~s}^{\mathrm{a}} \\
\end{array}$ \\
\hline & \multicolumn{9}{|c|}{ Annual Dose, $\mu \mathrm{Sv} / \mathrm{yr}$} \\
\hline \multicolumn{10}{|l|}{ Kara Sea instantaneous } \\
\hline Fish & $6.4 \times 10^{-4}$ & $2.6 \times 10^{-3}$ & $4.4 \times 10^{-3}$ & $6.0 \times 10^{-5}$ & $4.3 \times 10^{-6}$ & $2.5 \times 10^{-3}$ & $2.6 \times 10^{-4}$ & $1.7 \times 10^{-4}$ & $2.0 \times 10^{-3}$ \\
\hline Mammals & $2.7 \times 10^{-3}$ & $3.8 \times 10^{-3}$ & $1.8 \times 10^{-2}$ & $1.3 \times 10^{-5}$ & $9.6 \times 10^{-5}$ & $4.6 \times 10^{-5}$ & $6.0 \times 10^{-3}$ & $2.0 \times 10^{-3}$ & $3.7 \times 10^{-2}$ \\
\hline Birds/eggs & $1.6 \times 10^{-4}$ & $2.6 \times 10^{-3}$ & 0.0 & 0.0 & $4.7 \times 10^{-5}$ & $7.3 \times 10^{-5}$ & $4.3 \times 10^{-4}$ & $1.9 \times 10^{-3}$ & $3.0 \times 10^{-3}$ \\
\hline Mollusks & 0.0 & 0.0 & 0.0 & 0.0 & $4.1 \times 10^{-5}$ & $1.5 \times 10^{-5}$ & 0.0 & 0.0 & 0.0 \\
\hline Totals & $3.5 \times 10^{-3}$ & $3.0 \times 10^{-3}$ & $2.2 \times 10^{-2}$ & $7.2 \times 10^{-5}$ & $1.9 \times 10^{-4}$ & $7.2 \times 10^{-3}$ & $6.7 \times 10^{-3}$ & $4.1 \times 10^{-3}$ & $8.7 \times 10^{-3}$ \\
\hline \multicolumn{10}{|l|}{ Kara Sea time-varying } \\
\hline Fish & $1.3 \times 10^{-5}$ & $5.3 \times 10^{-5}$ & $9.0 \times 10^{-5}$ & $1.8 \times 10^{-6}$ & $1.4 \times 10^{-7}$ & $5.1 \times 10^{-5}$ & $4.0 \times 10^{-6}$ & $3.5 \times 10^{-6}$ & $4.1 \times 10^{-5}$ \\
\hline Mammals & $5.8 \times 10^{-5}$ & $8.3 \times 10^{-4}$ & $3.9 \times 10^{-4}$ & $4.1 \times 10^{-7}$ & $3.1 \times 10^{-6}$ & $1.0 \times 10^{-4}$ & $1.3 \times 10^{-4}$ & $4.5 \times 10^{-5}$ & $8.1 \times 10^{-5}$ \\
\hline Birds/eggs & $3.2 \times 10^{-6}$ & $5.1 \times 10^{-5}$ & $0.0 \times 10^{0}$ & $0.0 \times 10^{0}$ & $1.4 \times 10^{-6}$ & $4.2 \times 10^{-5}$ & $2.5 \times 10^{-4}$ & $1.1 \times 10^{-3}$ & $1.8 \times 10^{-3}$ \\
\hline Mollusks & $0.0 \times 10^{0}$ & $0.0 \times 10^{0}$ & $0.0 \times 10^{0}$ & $0.0 \times 10^{0}$ & $1.2 \times 10^{-7}$ & $2.9 \times 10^{-7}$ & $0.0 \times 10^{0}$ & $0.0 \times 10^{0}$ & $0.0 \times 10^{0}$ \\
\hline Totals & $7.5 \times 10^{-5}$ & $2.3 \times 10^{-4}$ & $4.8 \times 10^{-4}$ & $2.2 \times 10^{-6}$ & $4.7 \times 10^{-6}$ & $1.9 \times 10^{-4}$ & $3.9 \times 10^{-4}$ & $1.1 \times 10^{-3}$ & $1.9 \times 10^{-3}$ \\
\hline \multicolumn{10}{|l|}{ Accidental Riverine Sources } \\
\hline Fish & $7.6 \times 10^{-5}$ & $3.1 \times 10^{-4}$ & $5.1 \times 10^{-4}$ & $7.2 \times 10^{-6}$ & $5.4 \times 10^{-7}$ & $3.0 \times 10^{-4}$ & $3.2 \times 10^{-5}$ & $2.1 \times 10^{-5}$ & $2.4 \times 10^{-4}$ \\
\hline Mammals & $1.4 \times 10^{-4}$ & $2.1 \times 10^{-4}$ & $9.7 \times 10^{-4}$ & $6.4 \times 10^{-7}$ & $4.9 \times 10^{-6}$ & $2.5 \times 10^{-4}$ & $3.3 \times 10^{-4}$ & $1.1 \times 10^{-4}$ & $2.0 \times 10^{-4}$ \\
\hline Birds/eggs & $1.4 \times 10^{-4}$ & $2.2 \times 10^{-3}$ & $0.0 \times 10^{0}$ & $0.0 \times 10^{0}$ & $4.2 \times 10^{-5}$ & $6.4 \times 10^{-5}$ & $3.7 \times 10^{-4}$ & $1.6 \times 10^{-3}$ & $2.6 \times 10^{-3}$ \\
\hline Mollusks & $0.0 \times 10^{0}$ & $0.0 \times 10^{0}$ & $0.0 \times 10^{0}$ & $0.0 \times 10^{0}$ & $9.0 \times 10^{-8}$ & $3.3 \times 10^{-8}$ & $0.0 \times 10^{0}$ & $0.0 \times 10^{0}$ & $0.0 \times 10^{0}$ \\
\hline Totals & $3.6 \times 10^{-4}$ & $2.7 \times 10^{-3}$ & $1.5 \times 10^{-3}$ & $7.8 \times 10^{-6}$ & $4.8 \times 10^{-5}$ & $6.1 \times 10^{-4}$ & $7.2 \times 10^{-4}$ & $1.8 \times 10^{-3}$ & $3.1 \times 10^{-3}$ \\
\hline \multicolumn{10}{|l|}{ Chronic Riverine Sources } \\
\hline Fish & $2.9 \times 10^{-5}$ & $1.2 \times 10^{-4}$ & $2.0 \times 10^{-4}$ & $4.0 \times 10^{-6}$ & $3.0 \times 10^{-7}$ & $1.1 \times 10^{-4}$ & $1.2 \times 10^{-5}$ & $7.8 \times 10^{-6}$ & $8.9 \times 10^{-5}$ \\
\hline Mammals & $3.7 \times 10^{-5}$ & $5.3 \times 10^{-5}$ & $2.5 \times 10^{-4}$ & $2.6 \times 10^{-7}$ & $2.0 \times 10^{-6}$ & $6.4 \times 10^{-5}$ & $8.3 \times 10^{-5}$ & $2.8 \times 10^{-5}$ & $5.2 \times 10^{-5}$ \\
\hline Birds/eggs & $6.3 \times 10^{-5}$ & $1.0 \times 10^{-3}$ & $0.0 \times 10^{0}$ & $0.0 \times 10^{0}$ & $2.8 \times 10^{-5}$ & $2.9 \times 10^{-5}$ & $1.7 \times 10^{-4}$ & $7.3 \times 10^{-4}$ & $1.2 \times 10^{-3}$ \\
\hline Mollusks & $0.0 \times 10^{0}$ & $0.0 \times 10^{0}$ & $0.0 \times 10^{0}$ & $0.0 \times 10^{0}$ & $4.9 \times 10^{-8}$ & $1.2 \times 10^{-8}$ & $0.0 \times 10^{0}$ & $0.0 \times 10^{0}$ & $0.0 \times 10^{0}$ \\
\hline Totals & $1.3 \times 10^{-4}$ & $1.2 \times 10^{-3}$ & $4.4 \times 10^{-4}$ & $4.3 \times 10^{-6}$ & $3.0 \times 10^{-5}$ & $2.0 \times 10^{-4}$ & $2.6 \times 10^{-4}$ & $7.7 \times 10^{-4}$ & $1.3 \times 10^{-3}$ \\
\hline
\end{tabular}

a Doses calculated using dietary information for the $1960 \mathrm{~s}$. 
mated fish-consumption rate for an individual with a subsistence life-style in Barrow is about 27 $\mathrm{lb} / \mathrm{yr}$. An adjustment also must be made for radioactive decay of the radionuclides in the food between the time they are caught and the time they are eaten. For all radionuclides considered this is negligible because of their long half-lives (except for ${ }^{210} \mathrm{Po}$, for which it is a factor of 0.46 ). The individual's annual dose is just the product of these factors, with the units made to conform: $\left(7.1 \times 10^{-4} \mathrm{~Bq} / \mathrm{m}^{3}\right)\left(0.1 \mathrm{~m}^{3} / \mathrm{kg}\right)(27 \mathrm{lb} / \mathrm{yr})(0.454 \mathrm{~kg} / \mathrm{lb})\left(1.4 \times 10^{-8} \mathrm{~Sv} / \mathrm{Bq}\right)\left(10^{6} \mu \mathrm{Sv} / \mathrm{Sv}\right)(1.0)=$ $1.2 \times 10^{-5} \mathrm{mSv}$.

Table 6.5 indicates that the total dose for these assumptions is $1.3 \times 10^{-5} \mu \mathrm{Sv} / \mathrm{yr}$, which shows that ${ }^{137} \mathrm{Cs}$ contributes over $95 \%$ of the dose.

\subsubsection{Doses from Releases to the $\mathrm{Ob}$ and Yenisey Rivers}

Existing radionuclide releases to the major western Siberian river systems consist mainly of runoff from global fallout deposited on the watersheds of the $\mathrm{Ob}$ and Yenisey rivers. As described in Section 2, large releases of fission products from the former-Soviet nuclear-processing facilities, have not resulted in dramatic increases in concentration at the mouths of the rivers. If the current rates of discharge into the Kara Sea continue at rates declining only through radioactive decay, the doses in the future will be somewhat lower than they are today. The RAIG analyzed two riverine release scenarios, a worst-case one involving the yearlong release of the entire inventories of ${ }^{90} \mathrm{Sr}$ and ${ }^{137} \mathrm{Cs}$ from reservoirs at Mayak on the $\mathrm{Ob}$ River, and the other the slow leakage of liquid wastes from reservoirs as well as watershed runoff along both river systems, focusing on ${ }^{90} \mathrm{Sr}$. The predicted doses for these releases are shown in Table 6-5. Note that they represent only a small percentage of the dose one receives from global fallout, as presented above in Table 6-4. This is reasonable, because the global fallout in the Arctic comprises that which fell directly into the ocean, that which washed off from North American and other Asian rivers, as well as that fraction from the $\mathrm{Ob}$ and Yenisey rivers.

The source of these doses, too, will decrease exponentially with time because of the radiological decay of the radionuclides. The primary radionuclide released in the riverine scenarios is ${ }^{90} \mathrm{Sr}-$ in large part because ${ }^{137} \mathrm{Cs}$ is depleted in waste waters because of particle scavenging and therefore less is available for transport. The predicted doses for the accidental and chronic release scenarios are comparable because the total inventories released to the Kara Sea $(\sim 1 \mathrm{PBq})$ over time are similar. However, the peak doses occur about 30 years later in the Beaufort and Chukchi seas as a result of the slower discharge to the Kara Sea estuary.

\subsection{UnCERTAINTY AND SENSITIVITY ANAlysis}

To help understand the key parameters and assumptions involved in making our dose estimates, the RAIG performed a series of simple uncertainty analyses using computer spreadsheets and accessories to determine the overall ranges of the estimated doses (Decisioneering, 1993). To date, the analyses have not included the source-term or transport portions of the RAIG model, but only the environmental accumulation and dosimetry portions. Overall, the dose results appear to have a lognormal distribution, with a geometric standard deviation of about 2 . This indicates that the overall doses can be estimated with fair precision (to within a factor of about 4 high or low, with $90 \%$ confidence). In environmental modeling, this represents an acceptable level of reliability in the answer. 
For the evaluation of background doses, the doses and their uncertainties are controlled by the range of measured values of ${ }^{210} \mathrm{Po}$ in fish and mammals. The RAIG has an insufficient number of measurements of marine mammals or seabirds to allow for high precision on these estimates. Additional work in this area would be beneficial.

Uncertainties in doses from riverine sources are dominated by the range of bioaccumulation factors for ${ }^{137} \mathrm{Cs}$ in fish and mammals. Because there is a large body of these measurements, the RAIG assumes that this reflects natural variability of ${ }^{137} \mathrm{Cs}$ uptake in these resources. The uncertainties in dose from both historical background and future waste-related releases are also dominated by the variability in the bioaccumulation for ${ }^{137} \mathrm{Cs}$. Overall, doses from the pathways of

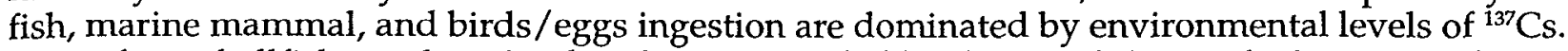
Doses from shellfish, on the other hand, are controlled by the variability in the bioaccumulation factors for ${ }^{239} \mathrm{Pu}$ and ${ }^{241} \mathrm{Am}$. However, in the situation as the RAIG understands it in Alaska, this pathway is only a marginal contributor to doses, and therefore the uncertainty in the actinide uptake by shellfish is of minor importance.

\subsection{ASSESSMENT OF RISKS}

The following discussion of radiation risk is adapted from the Health Physics Internet site at the University of Michigan (Busby, 1996).

Radiation causes ionizations in the molecules of living cells. These ionizations result in the removal of electrons from the atoms, forming ions or charged atoms. The ions formed then can go on to react with other atoms in the cell, causing damage. An example of this would be if a gamma ray passes through a cell, the water molecules near the DNA might be ionized and the ions might react with the DNA, causing it to break.

At low dose rates, such as what humans receive every day from background radiation or our estimates of dose rate resulting from Arctic contamination, the cells usually repair the damage rapidly. Occasionally, the cells may be unable to repair the damage and may either be changed permanently or die. Most cells that die are of little consequence, the body can just replace them. Cells changed permanently may go on to produce abnormal cells when they divide. In the right circumstance, these cells may become cancerous. This is the origin of our increased risk in cancer, as a result of radiation exposure.

At even higher doses, the cells cannot be replaced fast enough and tissues fail to function. An example of this would be "radiation sickness." This is a condition that results after high doses to the whole body $(>1,000,000 \mu \mathrm{Sv})$, where the intestinal lining is damaged to the point that it can no longer take in water and nutrients and protect the body against infection. This leads to nausea, diarrhea, and general weakness. With higher whole-body doses $(>3,000,000 \mu \mathrm{Sv})$, the body's immune system is damaged and cannot fight off infection and disease. At whole-body doses near $4,000,000 \mu \mathrm{Sv}$, if no medical attention is given, about $50 \%$ of the people are expected to die within 60 days of the exposure, mostly from infections. No doses are projected to reach these levels for anyone living around the Arctic Ocean from the radionuclide releases that have occurred or are projected to occur.

Risk estimates for radiation were first evaluated by scientific committees in the 1950s. The estimates are under continual review and updating, and numerous groups have reached essentially 
the same conclusions. Studies by the U.S. Environmental Protection Agency (Puskin and Nelson 1994), the National Council on Radiation Protection and Measurements (NCRP 1993), the British National Radiological Protection Board (NRPB 1993), and the International Commission on Radiological Protection (ICRP 1990) have focused on estimating the risks associated with radiation exposure.

It is difficult to estimate radiation risks because most of the radiation exposures that humans receive are very close to background levels. In most cases, radiation effects are not distinguishable from diseases occurring for other reasons. With the beginning of radiation use in the early part of the century, however, the early radiation researchers and users were not as careful as we are today. The information from medical uses and from the survivors of the atomic bombs in Japan has given us most of what the RAIG knows about radiation and its effects on humans. Risk estimates have their limitations:

1. The doses from which risk estimates are derived were much higher than the doses projected here;

2. The dose rates were much higher than normally received;

3. The actual doses received by the bomb survivors and some of the medical-treatment cases have had to be estimated and are not known precisely; and

4. Many other factors, as ethnic origin, natural levels of cancers, diet, smoking, and stress affect the estimates.

According to the scientific groups mentioned above, the risk of cancer death is about $10 \%$ per million $\mu S v$ for doses received rapidly (acute) and might be about half that ( $5 \%$ per million $\mu S v$ ) for doses received over a long period (chronic). These risk estimates are an average for all ages, males and females, and all forms of cancer. A great deal of uncertainty is associated with the estimate. The estimates made by the various groups discussed above are not exactly the same as these, because of differing methods of calculating risk and assumptions used in the calculations, but all are close.

The real question is: how much will the radiation exposures estimated in this report increase the chances of cancer death over a lifetime or the chances of subsequent generations of children or grandchildren?

To answer this, the RAIG must make a few general statements of understanding. First, in the United States the current death rate from cancer is about $20 \%$ : in any group of 10,000 U.S. citizens, about 2,000 of them will die of cancer. Second, because the induction of cancer is a random process, the RAIG can estimate that about $20 \%$ will die from cancer but cannot determine which individuals will actually die. Finally, a conservative estimate of risk from low radiation doses is thought to be one in which the risk is linear with dose, that is, that the risk increases with a subsequent increase in dose. Most scientists believe that this is a conservative model of the risk.

If one were to take a large population, such as 100,000 people, and expose each of them to radiation amounting to $1,000 \mu \mathrm{Sv}$ (to his or her whole body), one would expect about 10 additional deaths (i.e., $10 \%$ per million microsievert multiplied by 100,000 people times $1,000 \mu \mathrm{Sv}$ ). So, instead of the 20,000 people expected to die from cancer naturally, one would now have 20,010. This small increase in the expected number of deaths would not be seen in this group, because of natural fluctuations in the rate of cancer. What needs to be remembered is that it is not known 
that 10 people will die, but that there is a risk of 10 additional deaths in a group of 100,000 people if they all received a radiation dose of $1,000 \mu \mathrm{Sv}$ instantaneously. If they received the $1,000 \mu \mathrm{Sv}$ over a long period, such as a year, the risk would be less than half of this $(<5$ expected fatal cancers).

The doses predicted for the Alaskan coastal communities in this assessment from Russian releases are very small. The highest doses for Alaskans from Russian waste-disposal activities are about $0.02 \mu \mathrm{Sv}$ per year. If a person were to expose his or her entire life (about 70 years) to these dose rates, his/ her total dose would be about $2 \mu \mathrm{Sv}$. Even if the entire Alaskan coastal population of about 18,000 people received these doses, the expected number of fatal cancers above those expected naturally in this group would be less than 1 . In essence, there is no anticipated risk to the population of Alaska from the historic Russian waste disposal activities via marine pathways where ingestion of contaminated seafoods is the principal pathway of exposure.

\subsection{RISK V. BENEFITS}

In evaluating contaminants in subsistence foods it is important to address risks and benefits. If recommendations are made to limit a food because of contamination, then one must consider what may be consumed in its place (Nobmann, 1996). Any changes in dietary patterns wrought by concerns with contaminants can have broad impacts (Usher et al., 1995). This is especially true in Alaska Native communities where social structures and customs have evolved based on successfully obtaining sea mammals. The positive aspects of sharing the work, dividing the harvest, and celebrating the success of providing marine mammals in the community extend beyond the food's value as a source of nutrients (Nobmann,1996).

Work continues on an international scale to minimize the amount of man-made radionuclides entering the environment, and the levels continue to drop in the overall Arctic environment. Assessment of the dose received from the consumption of man-made radionuclides in marinesubsistence foods results in finding that it is well below that observed to cause acute effects. Risk to the public health from the man-made radionuclides in the marine-subsistence foods is very small. Benefits from the consumption of these foods outweigh any risk posed by these man-made radionuclides. For example, the consumption of sorne traditional foods is associated with cardiovascular-disease prevention (Nobmann, 1996). The RAIG therefore recommends that Alaskan residents make no changes to their life-styles in response to the disclosures of past Russian waste dumping in the Arctic.

\subsection{SuMMARY}

- Our analyses of doses associated with naturally occurring ${ }^{210} \mathrm{Po}$ and background levels of ${ }^{137} \mathrm{Cs}$ and ${ }^{90} \mathrm{Sr}$ in Arctic water indicate that the largest doses to individuals living in Alaskan coastal communities who consume subsistence seafoods is from ${ }^{210} \mathrm{Po}$, followed by ${ }^{137} \mathrm{Cs}$ and ${ }^{90} \mathrm{Sr}$, derived from global nuclear fallout.

- The nuclear sources the assessment dealt with included reactor-related components in the Kara Sea and radioactive wastewaters stored at nuclear facilities on the $\mathrm{Ob}$ and Yenisey riv- 
ers, which drain into the Kara Sea. Two types of release scenarios were used to represent the discharge of radionuclides to Arctic waters and rivers: one involves acute releases and the other, slow, chronic discharges.

- Although very low, the highest predicted doses to Alaskan coastal residents were for the instantaneous release of ${ }^{241} \mathrm{Am},{ }^{137} \mathrm{Cs},{ }^{239} \mathrm{Pu}$, and ${ }^{90} \mathrm{Sr}$ contained in the Kara Sea wastes. These doses, however, were well below background levels for ${ }^{210} \mathrm{Po}$ and nuclear fallout. The corrosion-driven chronic release of nuclides from the nuclear reactors, which is a far more realistic release scenario, results in doses that are about 100 times lower than the acute case.

- The acute and chronic discharges of ${ }^{90} \mathrm{Sr}$ and ${ }^{137} \mathrm{Cs}$ from wastewater storage ponds and reservoirs into the $\mathrm{Ob}$ and Yenisey rivers produce doses as low as chronic discharge of radioactive wastes in the Kara Sea.

- The potential health risks associated with the ingestion of Alaskan seafoods containing radionuclides derived from hypothetical releases from Russian nuclear wastes are extremely low, which essentially means that those wastes pose no threat to human health. Alaska Native communities need not alter any of their dietary habits associated with subsistence foods obtained from Alaskan waters on the basis of concern over radioactivity stemming from wastemanagement practices in the FSU, based on the RAIG analysis. 


\section{Assessment Results, Conclusions, AND RECOMMENDATIONS}

$\mathrm{T}$ The primary goal of this risk assessment is to evaluate the health and environmental threat to coastal Alaska posed by the FSU's dumping of radioactive wastes in the Arctic and North west Pacific Oceans. In particular, 16 nuclear reactors from submarines and an icebreaker were discarded in the Kara Sea near the island of Novaya Zemlya, of which 6 contained spent nuclear fuel; liquid and solid wastes were disposed in the Sea of Japan; a ${ }^{90} \mathrm{Sr}$-powered radioisotope thermoelectric generator was lost at sea in the Sea of Okhotsk; and several disposal sites for liquid wastes were located in the Pacific Ocean east of the Kamchatka Peninsula. In addition to these known sources in the oceans, FSU waste-disposal practices at inland weapons-development sites have resulted in contamination of major rivers flowing into the Arctic Ocean; these are evaluated for their ongoing and potential sources. For these sources, the RAIG evaluated the potential for release to the environment, transport, and impact to Alaskan ecosystems and peoples through a variety of scenarios.

\subsection{Assessment ConteXt}

This assessment addresses the potential for ecological and human risk, resulting from known and predicted levels of contaminants in the Arctic Ocean and its immediate vicinity. The assessment does not address inventories in currently operating Russian or American naval vessels, or in wastes currently being managed at Russian naval yards.

The first principal activity for the risk assessment was to characterize the sources of radionuclides in the Arctic seas. This included not only the FSU sources of interest in the Kara Sea and Northwest Pacific, but potential sources through riverine transport from Russian watersheds to the Arctic Ocean. Additionally, to place these sources into perspective and to obtain a comprehensive understanding, also characterized were the already existing fallout levels of key radionuclides; wastes from the Chernobyl incident and from European fuel reprocessing facilities at Sellafield (United Kingdom) and La Hague (France); and naturally occurring radioactivity. The initial list of potential contaminants was screened to a manageable number of contaminants likely to produce the greatest risk to the environment or human health. This process was based on a set of simple exposure equations. The final list was established to provide reasonable assurance that the preponderance of the risk of either long-term carcinogenicity of humans or long-term survival of aquatic biota was addressed. Additional considerations were given to known sources of radioactive materials.

The spatial domain and spatial scale of the analyses were established in consultation with ONR and other ANWAP researchers. The agreed focus was on coastal Alaska. To best represent the environmental conditions and state of knowledge relative to contaminant transport in the Arctic, 
the study area was divided into 21 compartments. A compartmental model was developed to predict the transport of radionuclides from disposal sites to other portions of the Arctic.

The RAIG established the indicators that would be used to judge the degree of hazard. For the ecological risk assessment, this consisted of defining a set of indicator species for which comparisons against toxicological benchmarks would be made, and for humans, a range of potential dietary exposures for Alaskans with subsistence life-styles was chosen. The selection of the indicator species is described in Section 5. For the human risk assessment, a suite of nine human exposure scenarios relating to subsistence life-styles at different locations was developed, described in Section 6. Human risk is limited to individual long-term carcinogenicity. The scenarios cannot address cultural impact or multigenerational impact of the exposures.

\subsection{Assessment Results}

\subsubsection{Sources}

Screening analyses indicate that the principal radionuclides of concern are ${ }^{241} \mathrm{Am},{ }^{137} \mathrm{Cs},{ }^{239} \mathrm{Pu}$, and ${ }^{90} \mathrm{Sr}$. The screening indicates that the most credible sources in terms of future impacts to Alaskan waters are the wastes disposed of in the Kara Sea and the liquid radioactive wastes stored at inland locations in Russia. Other sources, such as those in the Sea of Okhotsk or the Sea of Japan, are essentially inconsequential in Alaskan Arctic waters.

Background concentrations resulting from historical nuclear testing and past accidents currently exist in the Arctic. Relatively uniform levels of the key radionuclides are present throughout the Arctic waters from these sources. In addition, operation of the Sellafield nuclear reprocessing facility in Great Britain has resulted in the discharge of about $41,000 \mathrm{TBq}$ of ${ }^{137} \mathrm{Cs}$ and $590 \mathrm{TBq}$ of ${ }^{239} \mathrm{Pu}$ to the Irish Sea through 1992. Of this amount, an estimated $9,000 \mathrm{TBq}$ of ${ }^{137} \mathrm{Cs}$ and $20 \mathrm{TBq}$ of ${ }^{239} \mathrm{Pu}$ is estimated to have reached the Arctic Ocean. Concentrations from these sources in Alaskan waters are currently about $0.001,2,0.005$, and $1 \mathrm{~Bq} / \mathrm{m}^{3}$ of ${ }^{241} \mathrm{Am},{ }^{137} \mathrm{Cs}$, ${ }^{239} \mathrm{Pu}$, and ${ }^{90} \mathrm{Sr}$, respectively, down from highs in the $1960 \mathrm{~s}$ of about $0.009,14,0.05$, and $9 \mathrm{~Bq} / \mathrm{m}^{3}$. In contrast, naturally occurring ${ }^{210} \mathrm{Po}$ is present worldwide at about $1 \mathrm{~Bq} / \mathrm{m}^{3}$ in seawater.

Marine reactors dumped in the Kara Sea contain about $1,000 \mathrm{TBq}$ of ${ }^{137} \mathrm{Cs}$ and $6 \mathrm{TBq}$ of ${ }^{239} \mathrm{Pu}$. These will be released over time from corrosion/dissolution of the fuel. In addition, inland storage of liquid radioactive wastes holds about $1,400 \mathrm{TBq}$ of ${ }^{90} \mathrm{Sr}$ and $24 \mathrm{TBq}$ of ${ }^{137} \mathrm{Cs}$. These sources of radionuclides were modeled using two different types of scenarios: one to represent acute or accidental releases and the other to represent chronic or expected releases. The time-dependent chronic-release scenario results from the reactors in the Kara Sea are presented in Figure 2-7. The chronic-release scenario results from the inland sources consist of a base discharge of $40 \mathrm{TBq} / \mathrm{yr}$ of ${ }^{90} \mathrm{Sr}$ from reservoir leakage that declines as a function of time with the radioactive decay of the ${ }^{90} \mathrm{Sr}$. 'Ihe acute releases for both the Kara Sea and inland sources are essentially instantaneous releases of the entire inventories. 


\subsubsection{Transport}

A compartmental modeling approach was used to simulate the transport of radionuclides from the Kara Sea nuclear wastes and riverine sources to Alaskan waters. Water flows between compartments were estimated using a coupled ice-ocean circulation model. Radionuclide losses within a given compartment were modeled to occur via sedimentation and radioactive decay. The model is capable of simulating discrete as well as time-varying releases of radionuclides to Arctic Ocean waters over long periods of time (decades to centuries). Because of low sorption coefficients and low particle loadings in the Arctic Ocean, radionuclide transport is dominated by water currents rather than sedimentation processes. The RAIG also found that the transport capacity of the coastal currents also is greater than the capacity associated with ice and entrained sediment. It benchmarked its simulations against other models of the transport of radionuclides in the Arctic, and found good agreement.

The predicted concentrations in the Beaufort, Bering, and Chukchi seas of the four key radionuclides from FSU releases were much lower than either historic or current levels. Measured data on the concentrations of these radionuclides in Alaskan waters indicate that the highest levels occurred in the 1960 s as a result of global fallout. The highest predicted concentration of ${ }^{137} \mathrm{Cs}$ is $0.032 \mathrm{~Bq} / \mathrm{m}^{3}$ in the Beaufort Sea following an assumed instantaneous release to the Kara Sea from the disposed nuclear wastes. This level is much lower than the $2 \mathrm{~Bq} / \mathrm{m}^{3}$ of ${ }^{137} \mathrm{Cs}$ measured in the $1990 \mathrm{~s}$, and lower still than the $14 \mathrm{~Bq} / \mathrm{m}^{3}$ measured in the $1960 \mathrm{~s}$. A more realistic scenario, in which the radionuclides are released slowly to the Kara Sea as a result of corrosion and dissolution processes, results in predicted peak concentrations of only $0.0007 \mathrm{~Bq} / \mathrm{m}^{3}$. The time-dependent concentrations of the key radionuclides are presented in Figures 3.8 through 3.10 .

\subsubsection{Ecological Risks}

In order to evaluate the future exposures to marine biota, and humans that eat them, the RAIG compiled data on bioconcentration factors (BCFs). The BCFs are a commonly used, unitless, parameter that describe bioaccumulation processes resulting from transfer of radionuclides from ecosystem components (water, particulate matter, food) into organisms. The RAIG was able to recommend BCFs for groups of marine organisms from different trophic levels in Arctic ecosystems. A key result is that BCFs in Arctic systems do not seem to vary significantly from those in more temperate ecosystems.

The RAIG established minimum dose and dose rate levels, called No Observable Effects Levels (NOELS), for radiation effects on biota. The effects considered included mortality, sterility, and reduced fertility. The NOELS for fertility correspond to the lowest concentrations of radionuclides in seawater.

Using the predicted radionuclide concentrations in water with the $\mathrm{BCFs}$, the team calculated accumulation of the key radionuclides in Arctic biota, and then estimate the radiation dose rates to these biota. Our predicted dose rates from incremental increases in radiation from FSU sources are all three to five orders of magnitude lower than our lowest dose-rate NOELS. Therefore, the following are the conclusions from our risk assessment for marine biota in Alaskan waters: 
- The dose and dose rates that cause mortality to marine species are not expected to occur in the Arctic as a result of FSU dumping.

- The doses and dose rates causing sterility, or even decreased fertility, are not expected to occur in the Arctic as a result of FSU dumping.

- There is no indication that there will be any decrease or loss in indigenous populations or any damage to ecosystems through decreases in biodiversity.

\subsubsection{Human Risk}

Our analyses of doses associated with naturally occurring ${ }^{210} \mathrm{Po}$ and background levels of ${ }^{137} \mathrm{Cs}$ and ${ }^{90} \mathrm{Sr}$ in Arctic water indicate that the largest doses to individuals living in Alaskan coastal communities who consume subsistence seafoods is from ${ }^{210} \mathrm{Po}$, followed by ${ }^{137} \mathrm{Cs}$ and ${ }^{90} \mathrm{Sr}$ derived global nuclear fallout. Doses from ${ }^{210} \mathrm{Po}$ can range as high as $1,500 \mu \mathrm{Sv} / \mathrm{yr}$; doses from fallout were as high as $10 \mu \mathrm{Sv} / \mathrm{yr}$ in the 1960s, and are now around $1 \mu \mathrm{Sv} / \mathrm{yr}$.

Although very low, the highest predicted doses to Alaskan coastal residents were for the instantaneous release of ${ }^{241} \mathrm{Am},{ }^{137} \mathrm{Cs}$, ${ }^{239} \mathrm{Pu}$, and ${ }^{90} \mathrm{Sr}$ contained in the Kara Sea wastes. The highest of these estimated values was about $0.1 \mu \mathrm{Sv} / \mathrm{yr}$. However, the highest predicted doses from FSU sources were well below doses from background levels of ${ }^{210} \mathrm{Po}$ and nuclear fallout. The corrosion-driven chronic release of nuclides from the nuclear reactors, which is a far more realistic release scenario, results in doses that are about 100 times lower than the acute case, with a peak of about $0.001 \mu \mathrm{Sv} / \mathrm{yr}$.

The acute and chronic discharges of ${ }^{90} \mathrm{Sr}$ and ${ }^{137} \mathrm{Cs}$ from wastewater storage ponds and reservoirs into the $\mathrm{Ob}$ and Yenisey rivers produce doses that are as low as chronic discharge of radioactive wastes in the Kara Sea, generally no higher than about $0.001 \mu \mathrm{Sv} / \mathrm{yr}$.

\subsection{Extension of Results to Other Contexts}

The human risk assessments documented in Section 6 focus on Alaskan coastal residents consuming a subsistence diet. This is the set of people in Alaska, and in fact in the United States, most highly exposed to radionuclides from FSU dumping in the Arctic and other FSU wasterelated sources. Based on the results from this group, additional conclusions may be drawn regarding non-subsistence residents, visitors and tourists, and the Alaskan fishing industry as a whole.

\subsubsection{Non-Subsistence Residents}

Almost the only significant pathway of exposure to radioactive contaminants in Arctic waters is via the consumption of Arctic seafoods. Therefore, the radiation dose to residents who do not live a subsistence life-style is directly proportional to the quantity of seafoods caten. In general, nonsubsistence residents would be expected to eat less seafood than the types of subsistence residents defined in Section 6 . The current and projected doses to the subsistence residents from FSU radionuclides were extremely low. It is reasonable to assume that doses to non-subsistence resi- 
dents would be even lower, and that no impacts are to be expected to any residents of Alaska exposed via the seafood pathway.

\subsubsection{Visitors and Tourism}

Tourism and ocean sport fishing are a growing part of the Alaskan economy. Again, the primary pathway of exposure to visitors and tourists would be through the ingestion of seafoods caught in Alaskan waters. For most visitors, the amount consumed would be small relative to the diet of substance residents. Some individual sportsmen might bring home a substantial catch, and the resulting radiation dose could approach that of a subsistence resident. The doses and risks to any individual sportsman would be no larger than that of the subsistence residents, however, and no health impacts would be expected. There is no reason to expect that FSU dumping should have any impact on sport fishing or tourism in Alaska.

\subsubsection{Alaska Fishing Industry}

During immersion in seawater, fishing gear may entrain particles of sediment on which radioactivity is adsorbed. This applies particularly to fiber strands of which many items of fishing gear (e.g., ropes, nets, and pots) are composed. The potential for radiation doses from handling contaminated fishing gear has been evaluated for similar northern ocean fisheries. Models for exposure to fishermen have been developed (Hunt, 1984), applied at various sites (e.g., Shinohara and Asano, 1992), and even verified against direct measurements (Hunt, 1992). Exposures via this pathway are universally described as being of minor importance compared with the ingestion pathways (Hunt, 1984; Hunt, 1992; Shinohara and Asano, 1992). Because the doses via ingestion of fish are very low, such that health effects are not expected, the doses to fishermen from handling fishing gear will be inconsequential.

The incremental concentrations of FSU radionuclides projected for seafoods in the future are much lower than currently existing concentrations derived from fallout. These incremental concentrations will not be detectable above the background levels. Risks to any consumers of fish exported from Alaska would be no higher than those to subsistence residents. Therefore, there should be no danger of consumer resistance to Alaskan fish, and no risk to the Alaskan fishing industry from past FSU waste dumping.

\subsection{Possible Use of Results in Future Contexts}

The sources of radioactive release evaluated in this report are those currently in or entering the Arctic Ocean. However, the methods developed are applicable to other potential sources. Such sources could include nuclear submarines or stored spent nuclear fuel at military bases in Murmansk or Vladivostok (Dyer et al., 1996; Nilsen and Bohmer, 1994; Nilsen et al., 1996), and upcoming events such as expedited decommissioning of Russian nuclear submarines as envisioned under the U.S./Russian START II Treaty. These sources could potentially be very large, but because the plans for Russian disposition of these wastes are in a state of rapid change, they are not addressed in this report. The focus of funding for ANWAP was marine and riverine Russian sources. 
As radionuclide inventories, either planned or already disposed of in various locations around the Arctic Ocean, are identified, the methods described in this report could be applied and doses to people around the Arctic Rim could be estimated.

\subsection{CONCLUSIONS}

There is no indication that concentrations of radionuclides in Alaskan waters are currently elevated as a result of dumping by the FSU. The predicted concentrations of radionuclides in Alaskan waters from FSU dumping activities to date are so low in all cases as to make them undetectable against current background levels.

The ecological risks estimated for the coasts of Alaska are generally about 5 orders of magnitude below levels at which any effect would be expected. There is no indication that there will be any decrease or loss in indigenous populations or any damage to ecosystems through mortality, changes in fertility, or decreases in biodiversity.

The potential health risks associated with the ingestion of Alaskan seafoods containing radionuclides derived from releases from Russian nuclear wastes are extremely low, which essentially means that those wastes pose no threat to human health. No health effects are predicted. Alaska Native communities need not alter any of their dietary habits associated with subsistence foods obtained from Alaskan waters on the basis of concern over radioactivity stemming from wastemanagement practices in the FSU. Other economic or cultural activities should be unaffected.

\subsection{RECOMMENDATIONS}

\subsubsection{Monitoring}

The research revealed a dearth of information regarding uptake of radionuclides in Arctic marine mammals. Although it is unlikely that more information would change the conclusions of this report, more sampling of marine mammals, of organs as well as muscle consumed by residents, would strengthen the capability to predict impacts. Concurrent sampling of ocean water would help develop more accurate bioconcentration factors. Similar information about uptakes in birds, eggs, and other commonly eaten foods is needed. This research need not be performed only in Alaskan waters-data from other northern countries would be valuable as well.

Radionuclide fluxes down the major Siberian rivers contribute as much risk as the materials dumped directly into the Arctic. Very little sampling has been done in the long northern portions of these rivers. Additional monitoring data in these rivers' water, sediment, and biota would help in the understanding of their potential for transporting contaminants to the Arctic. 


\subsubsection{Research}

Much of the information in this analysis for the inland sources of contamination is derived from general descriptions lacking in detail. Additional international research on the current contents of the FSU fuel-cycle facilities at Krasnoyarsk, Tomsk, and Mayak is needed. The inventories and availabilities of all radionuclides in lakes, holding ponds, and groundwater sources are needed to better define the long-term potential for releases. In particular, better detail is needed on the long-lived, environmentally mobile radionuclides other than the easily detected ${ }^{137} \mathrm{Cs}$ or ${ }^{90} \mathrm{Sr}$.

The modeling done in this assessment for uptake and transport of radionuclides by ice showed it to be a minor contributor to radionuclide concentrations near Alaska. Part of the reason for this insensitivity to this transport route is that ice appears to primarily transport material across the Arctic from near Novaya Zemlya towards Greenland. Future assessments of the north Atlantic would benefit from additional study of this pathway's processes.

The dose modeling performed here assumes that the biota are at equilibrium with the surrounding seawater. The RAIG has no integrated view of the role of sediment and biota in the transport of radionuclides. More data on contaminant bioavailability in sediments, sediment transport, and biotic migration would improve assessments.

\subsubsection{Modeling}

The experience gained in conducting this assessment shows that there is an opportunity for closer cooperation between assessment modelers and the scientific groups developing ocean circulation models or performing tracer studies. The various groups involved in Arctic-contamination research should continue to work together to provide integration of ongoing experimental work into useful assessment information.

\subsubsection{Other}

Additional data on transport of materials in the Arctic Ocean could benefit assessment of numerous other contaminants. Much of the data used in the preparation of this report is of recent origin, and validation or verification is needed. Particularly important would be additional information on Arctic currents: their stability and longevity, influence of wind, and possible seasonal changes.

Although the analyses of this report suggest that transport of radionuclides in ice is not a major mechanism for moving contamination towards Alaska, it does appear to somewhat increase the transport towards Greenland. If the models and techniques developed for this report are considered for future assessments for other countries of the Arctic, additional information on the mechanisms of incorporation of sediments and contaminants in ice, and their transport, would be valuable.

The results of this report suggest that the largest impacts will be in the immediate vicinity of the Russian waste dump sites. Future monitoring to further evaluate the sources, locate others, and to validate the modeled source terms is suggested.

This report focused on aquatic sources and foods. It appears that the doses are dominated by natural background levels of ${ }^{210} \mathrm{Po}$ and radionuclides from global fallout. For complete perspec- 
tive, equivalent assessments of the terrestrial pathways for native subsistence life-styles would be beneficial.

The scope of this report was existing radioactive wastes in the marine environment and ongoing potential inland releases. Additional potential sources of radioactivity exist in the Russian Arctic, particularly nuclear wastes associated with Russian naval activities in Murmansk, Vladivostok, and other naval bases. The techniques developed here could also help evaluate the possible impact of hypothetical, or future actual, accidents in those areas. 


\title{
APPENDIX A: ECOSYSTEMS IN ARCTIC AREAS OF CONCERN
}

\begin{abstract}
$\mathrm{E}$ cosystems found in the Arctic are very diverse and differ greatly spatially. The large extremes in physical conditions-light regimes, nutrients, temperature, salinity, and currentscause differences in primary productivity, which affect the types of food webs and the numbers of individuals present. In Appendix A, the RAIG provides some background information about the specific areas of concern, brief descriptions of the different types of ecosystems, limited data on ecosystem structure and composition, and brief descriptions of the ecologically and economically important marine populations potentially at risk.
\end{abstract}

\section{A.1 Areas of Concern}

The ecology of the water masses in the Kara Sea and the Alaskan Shelf differ significantly in their properties and in the quantities of radionuclides that potentially may be distributed in their waters (see Sections 2 and 3). Because of these differences, the RAIG briefly describes some of the basic characteristics of the areas of concern.

\section{A.1.1 Kara Sea}

The climate of the Kara Sea differs widely with area and, in general, is more severe than that of the Barents Sea. This area has a large riverine input, which is highly variable with season. The hydrology is dominated by the influx of waters from the $\mathrm{Ob}$ and Yenisey rivers; the influx is very large during the summer season. This sea also has an extensive ice cover, and scouring by ice of the near-shore area restricts the distribution of some benthic biota and affects their survival.

The productivity of the Kara Sea is relatively low and is estimated to be about one-third to onefifth of that of the Barents Sea. The vegetative season is quite short, about 4 months, with both a spring and summer bloom. In the southern part of the Sea, the most productive part, the spring bloom occurs in July and attracts some migratory species. The offshore area of the Kara Sea is covered by ice most if not all year and is best characterized as a polar-ice ecosystem.

\section{A.1.2 Alaskan Shelf: Chukchi and Beaufort Seas}

The continental shelf of the Chukchi and Beaufort seas is generally wide. Typically, the benthicpelagic ecosystems along these seas are shallow, having a mean depth of $50 \mathrm{~m}$. Dominant factors in the ecology of the area are the formation and breakup of sea ice and scasonal input from large river systems. Because the ice cover is present about 9 months, beginning formation in late September and lasting until early July, the polar-ice-type ecosystem is present seasonally. The nearshore benthic community is limited because of ice scouring. In the spring, phytoplankton blooms occur on the underside of the ice and are a source of food for zooplankton. The Chukchi Sea may 
receive seasonally through the Bering Straits high nutrients and a higher quality organic matter, indicated by low $\mathrm{C} / \mathrm{N}$ ratios. This results in increased productivity and contributes to the richness of this region in fisheries resource, which affects the densities of marine mammals and marine seabirds. Habitats for large numbers of species are present.

The productivity of the Beaufort Sea is less than that of the Chukchi Sea, and ice algae may represent an important source of primary production (Dayton et al., 1994). Because the Beaufort Sea is predicted to receive the highest concentrations of the FSU-disposed radionuclides through worst-case scenarios, information on trophic levels and species is provided in Table A-1. The listings provided are undoubtedly incomplete because the area has not been investigated totally. An example of the kinds of information provided by in-depth studies is the investigation of the epifaunal and infaunal molluscan populations of the Northeastern Chukchi Sea by Feder and colleagues (Feder et al., 1994), who identified 139 molluscan taxa and determined the spatial distribution by cluster analysis. They sampled 37 stations, taking 5 replicate samples, and obtained data on 52 bivalves, 83 gastropods, 3 polyplacophorans, and 1 cephalopod. A listing of the species present is available in their paper's appendix, and some of the species found most frequently and with wide distribution are included in this report's description of the benthic-pelagic type ecosystem (Table A-1).

Coastal lagoons are numerous in some areas of the Alaskan shelf. The energy base includes old carbon detritus from peat, terrestrial carbon from rivers and peat, and marine phytoplankton. These are very productive areas and are important areas for growth of fishes and nesting of birds.

\section{A.1.3 Northern Bering Sea}

The Northern Bering Sea is a fisheries resource of importance for food for the indigenous Native populations living along its coast. In winter time about half of the Sea is covered with ice, and in summer time it is free of ice, but the surface temperatures remain cold except in selected nearshore areas. The coast line is diverse and includes coastal lagoons and rocky shores. In the areas where there is significant river inflow, there are habitats for shore birds and water fowl. Both the benthic-pelagic and offshore pelagic ecosystems have food webs that support large numbers of species in some areas (Becker, 1994).

There is a significant migration of biomass from the Northern Bering Sea to the Chukchi Sea, and local ice conditions determine its timing. Because the most northern parts of the Bering Sea undergo large seasonal changes, populations of marine species differ greatly during the year.

\section{A.2 TyPes OF ECOSYSTEMS}

\section{A.2.1 Polar-Ice Ecosystems}

The characteristics of polar-ice ecosystems were described by Becker (1994). Sea-ice communities are unique and include autotrophic and heterotrophic members. Food webs are relatively simple, and mammals rather than fishes tend to be at the top of the food web. Production is by ice algae, and these support zooplankton living under the ice. The zooplankton support over-wintering fishes, which are important in the diet of marine mammals in the ecosystem. Also, in the mar- 
ginal-ice community are a group of nektonic species and large herbivores, including seabirds and mammals.

An important factor affecting polar-ice ecosystems are polynyas, which are areas within the ice pack that are almost always clear of ice (Smith, 1990). Predators and prey are attracted to polynyas because the ice edges around them are highly productive areas. Polynyas and their ice-edge communities are important to seabirds; seabird rookeries are found in close proximity to them.

\section{A.2.2 Benthic-Pelagic Ecosystems}

The benthic-pelagic ecosystems in the Arctic differ widely from one geographical area to another. In some areas where the continental shelf is wide, there are still important biological interactions between the benthic and pelagic regions, even in areas far distant from land. The energy base consists of phytoplankton, ice algae, and, in some areas, benthic algae. Zooplankton are the food base for various indigenous and migratory fishes and for some mammals. Infauna species are also important in the food web.

\section{A.2.3 Offshore Pelagic Ecosystems}

The deeper and central parts of some Arctic seas are highly productive, and in some areas primary production is distributed through pelagic food webs. Zooplankton production is very important, especially the copepod-krill to capelin-cod food chain, in those areas with large populations of cod, seabirds, and seals (Savinova et al., 1995).

\section{A.2.4 Coastal Lagoons}

Along the shores of parts of the Chukchi and Beaufort seas and the Northern Bering Sea are shallow lagoons that support extensive food webs. The energy base for these lagoons is old carbon detritus, riverine input, and peat, as well as marine phytoplankton. The benthos supports an extensive fauna that are important in some food webs. Both indigenous and migratory fishes thrive in the lagoons and are preyed upon by marine mammals. 


\section{A.3 Basic Structure and Composition of Ecosystems}

Table A-1. Ecology of the Alaskan Shelf area: Chukchi and Beaufort seas. ${ }^{2}$

\section{A. Benthic-Pelagic-Type Food Web}

Trophic Level

(1) Energy Base

Phytoplankton $(80 \%)$, ice algae, benthic algae, kelp (Peard Bay offshore of Skull Cliffs; boulder patch in Steffansson Sound; south of Belvedere Island; western Camden Bay; Beaufort Lagoon; Demarcation Bay).

(2) Zooplankton

Copepods

Pelagic hyperiid and gammarid amphipods

Euphasiids

Chaetognaths

Medusae

Planktonic larvae of benthic invertebrates

(2) Infauna

Annelids

Scolopios armiger

Scolecolepides arctius

Nephthys caeca

Prionospio cirrifera

Spio filicornis

Ampharete stroemi

Tubifacid worms

Bivalves

Boreacola vadosa

Cyrtodaria kurriana

Nucla tenuis

Portlandia arctica

P. intermedia

Nuculana radiata

Loycyma fluctuosa

Yoldia hyperborea

Cyclocardia ovata

$Y$. myalis

Y. scisssurata

Macoma calcarea

Astarte montagui

A. borealis

Thyasira gouldi

Gastropods

Cylichna albaea

Retusa obtusa

Tachyrhynchus erosus

Solariella varicosa

Oenopota

S. obscura

Priapulids

Halicryptus spinulosus

Priapulus caudatus

$(2,3) \quad$ Epibenthic Invertebrates

Mysids 
Mysis litoralis

Euphausiids

Thysanoessa raschii

Amphipods

Pontoporeia femorata

P. affinis,

Onisimus litoralis

O. glacialis

Isopods

Saduria entomon

S. sabini

(3) Plankton-Eating Fish

Polar cod, Boreogadus saida

(3,4) Birds

Black guillemot, Cepphus grylle

Arctic tern, Sterna paradisae

Ross's gull, Rhodostethia rosea

Sabine's gull, Xema sabini

Red phalarope, Phalaropus fulicarius

Oldsquaw, Clangula hyemalis

Common eider, Somateria mollisima

Glaucous gull, Larus Hyperboreus

$(3,4,5)$ Mammals

Ringed seal, Phoca hispida

Bearded seal, Erignathus barbatus

Spotted seal, P. largha

Walrus, Odobenus rosmarus

Polar bear, Ursus martitimus

Gray whale, Eschrichtius robustus

Ribbon seal, Phoca fasciata

Harbor seal, Phoca vitulina

Stellar sea lion, Eumetopias jubatus

Sea otter, Enhydra lutris

\section{B. Offshore-Pelagic-Type Food Web}

Trophic Level

(1) Energy Base

Phytoplankton, ice algae, plankton and carbon from particles and plankton from the Bering Sea

(2) Zooplankton

Copepods

Decapod larvae

Barnacle larvae

Euphausids

Mysids 
(2) Infauna

Polychaetes

Bivalves

Amphipods, pelagic hyperiid and gammarid amphipods

(2) Epibenthic Invertebrates

Gastropods

Bivalves

(3) Fishes

Arctic cod, Boreogadus saida

$(3,4) \quad$ Birds

Black-legged kittiwake, Rissa tridactyla

Glaucous gull, Larus hyperboreus

Short-tailed shearwater, Puffinus tenuirostris

Ivory gull, Pagophila eburnea

(4) Marine Mammals

Bearded seal, Erignatus barbatus

Ringed seal, Phoca hispida

Bowhead whale, Balaena mysticetus

Polar bear, Ursus maritimus

\section{Coastal-Lagoon-Type Food Web}

Trophic Level

(1) Energy Base

Old carbon detritus (peat), terrestrial carbon (river input and peat), marine primary production (60-70\%).; eel grass (Zostera marina) in areas south of the Seward Peninsula

(2) Infauna (Depauperate):

Chironomids

Oligochaetes

Amphipods
Ampherusa glacialis
Garnaracanthus loricatus
Gammarus setosus
Pontoporeia affinis,
Onisimus gacialis

(2) Epibenthic Invertebrates

Mysids

Mysis litoralis,

$M$. relicta

Neomysis intermedia

N. rayii

Isopods

Saduria entomon 
(3) Fishes

Anadromous Fishes

Arctic cisco, Coregonus autumnalis

Least cisco, C. Sardinella

Broad whitefish, C. nasus

Humpback whitefish, C. clupeaformis

Arctic char, Salvelinus alpinus

Chum salmon, Oncorhynchus keta

Pink salmon, O. gorbuscha

Boreal smelt, Osmerus eperlanus

(in Chukchi Sea as far south as Peard Bay)

Marine Fishes

Saffron cod, Eleginus gracilis

Sand lance, Ammodytes hexapterus

Capelin, Mallotus villosus

Pacific herring, Clupea harengus pallasi

Fourhorn sculpin, Myoxocephalus quadriornis

Arctic cod, Boreogadus saida

$(3,4) \quad$ Birds

Black guillemot, Cepphus grylle

Arctic tern, Sterna paradisae

Ross's gull, Rhodostethia rosea

Sabine's gull, Xema sabini

Black-legged kittiwake, Rissa tridactyla

Red phalarope, Phalaropus fulicarius

Northern phalarope, P. logatus

Oldsquaw, Clangula hyemalis

Black brant, Branta bernicla

Glaucous gull, Larus hyperboreus

Snow goose, Chen caerulescens

(4) Marine Mammals

Spotted seal, Phoca largha

Beluga whale, Delphinapterus leucas

\section{Lancaster Sound}

Trophic Level

(1) Energy Base

$90 \%$ phytoplankton, $10 \%$ ice algae, $1 \%$ kelp

(2) Zooplankton

Copepods

Pseudocalanus acuspes

Calanus hyperboreus

C. glacialis

Metridia longa

Ctenophores 
(3) Infauna

Mya truncata

Macoma calcarea

Hiatella arctica

Serripes groenlandicus

$(2,3) \quad$ Epifaunal Invertebrates

Pycnogonids

Brittle stars

Sea urchins

Sea cucumber

Terebellid polychaetes

Anemones

(3.4) Fishes

Arctic cod, Boreogadus saida

$(3,4) \quad$ Birds

Thick-billed murre, Uria lomvia,

Northern fulmar, Fulmarus glacialis

Black-legged kittiwake, Rissa tridactyla

Black guillemot, Cepphus grylle

Glaucous gull, Larus hyperboreus

(4) Marine Mammals

Bearded seal, Frignatus barbatus

Ringed seal, Phoca hispida

Bowhead whale, Balaena mysticetus

Polar bear, Ursus maritimus

Ribbon seal, Phoca fasciata

\section{E. Offshore Polar-Ice Type Food Web}

Trophic Level

(1) Energy Base

Ice phytoplankton (diatoms)

(2) Under-Ice-Dwelling Invertebrates

Copepods

Amphipods

Onisimus glacialis

Ampherusa glacialis

Gammarus wilkitzkii

Mysids

(3) Overwintering Fish

Arctic cod,

Polar cod, Boreogadus saida

(3) Marine Birds 


\title{
(4,5) Marine Mammals \\ Gray whale, Eschrichtius robustus \\ Ringed seal, Phoca hispida \\ Polar bear, Ursus martitimus
}

\section{References}

Sazykina \& Kryshev (1994)

Savinova, Gabrielsen, and Falk-Petersen (1995)

Becker (1994)

Feder et al. (1994)

\begin{abstract}
a This table was compiled from references listed above and was provided for the reader to obtain some indication of the diversity in types of ecosystems and of the species. It is not claimed to be complete, and the animals included do not have the same ecological importance.
\end{abstract}


Figure A-1. Food chain of benthos-feeding marine mammals.

\section{Benthos-Feeding Marine Mammals}

(4) Gray Whale, Escrichitius robustus

(3) Bearded Seal, Erignathus barbatus

(3) Pacific Walrus, Odobenus rosmarus divergens

(2) Benthos Infauna

Annelids

Bivalves

Amphipods

Gastropods

(2) Benthos Epifauna

Mysids

Amphipods

Isopods

Crabs

Shrimp

Echinoderms 
Figure A-2. Food chain of piscivorous-feeding marine mammals.

\section{Piscivorous-Feeding Marine Mammals}

(4) Spotted Seal, Phyca largha

(4) Harbor Seal, Phoca vituline

(4) Beluga Whale, Delphinapterus leucas

(4) Narwhal, Monodon monoceros

(3) Marine Fish and Squid

Cods (polar cod and Arctic cod)

Pollock

Capelin

Sandlance

Flounders

Sculpins

Squid

(3) Anadromous Fish

Salmon

Arctic char

Ciscos

Smelt

Whitefish

(2) Ice Invertebrates

Copepods

Amphipods

Isopods

Mysids

(2) Infauna (in shallow areas)

Chronomids

Enchytroeids (oligochaetes) 
Figure A-3. Food chain of a mixed-feeding marine mammal.

\title{
Mixed-Feeding Marine Mammal
}

$(3,4)$ Ringed Seal, Phoca hiapida

\author{
(3) Marine Fish and Squid \\ Cods \\ Pollock \\ Capelin \\ Sandlance \\ Flounders \\ Sculpins \\ Squid
}

(3) Anadromous Fish

Salmon

Arctic char

Ciscos

Smelt

Whitefish

(2) Ice Invertebrates

$$
\begin{aligned}
& \text { Amphipods } \\
& \text { Isopods } \\
& \text { Mysids }
\end{aligned}
$$


Figure A-4. Food chain of a planktivorous marine mammal.

\section{Planktivorous Marine Mammal}

(3) Bowhead Whale, Balaena mysticetus

(2) Zooplankton

Copepods

Euphausiids

Crab and shrimp larvae

(1) Phytoplankton, Ice Algae, Detritus 
Figure A-5. Food chain of the polar bear, a marine mammal.

\title{
(5) Polar Bear, Ursus martitimus
}

\author{
$(3,4)$ Ringed Seal
}

(4) Piscivorous Marine Mammals

(3) Marine Fish and Squid

Cods

Pollock

Capelin

Sandlance

Flounders

Sculpins

Squid

(3) Anadromous Fish

Salmon

Arctic char

Ciscos

Smelt

Whitefish

(2) Ice Invertebrates

Amphipods

Isopods

Mysids

(1) Phytoplankton 


\section{A.4 Marine Populations at Risk}

\section{A.4.1 Ecologically Important Marine Populations at Risk}

Ecosystems descriptions provided for the Alaskan Shelf indicate that the trophic levels include species from most taxonomic groups. Thus, in predicting the effects of radiation on ecologically important organisms and those that may be endangered, the RAIG must consider information on ecosystem composition and on the effects of radiation on reproductive success of organisms from different taxonomic groups and trophic levels. Another important factor is that among the populations generally at greatest risk from radioactivity are those species that are low in fecundity (have few offspring), are slow to reach sexual maturity, and are long lived. Examination of the food webs in and species composition of Arctic ccosystems indicates that many species have these attributes (Table A-1).

Characteristics that make species potentially more vulnerable at the population level are not only radiosensitive reproductive tissues and early life stages but also a sparse distribution (small domain) in the ecosystem. The databases on species' domains in the Arctic also are limited. Information on domain is needed to determine species vulnerable to habitat disruption or loss of food-chain organisms. If the species domain is small and a high level of contamination encompasses the entire area, there is a potential for loss of the species from the ecosystem. If the domain is larger than the contaminated area, however, repopulation of the species from peripheral populations may occur upon cleanup or radioactive decay of radionuclides in the contaminated area.

The loss of ecologically important species may result in significant changes in ecosystem composition. Among trophic levels in ecosystems, primary producers and benthic species are of special interest: primary producers form the base of food webs, and benthic species live in or near bottom sediments that typically have high radionuclide concentrations and they are vitally important in food webs of many economically important species. Phytoplankton, however, are not potentially as vulnerable to radionuclide contamination as benthic species. The BCFs for phytoplankton are high for some radionuclides (Section 4, Table 4-6), but the total radionuclide content in any individual cell will be low and the discrete nature of the emission process means that many cells will pass through a number of divisions and experience no dose (UNSCEAR, 1996). Among benthic species, the RAIG will be concerned about the potential dose rates to small crustaceans, polychaete worms, and mollusks, some of which have high BCFs (Section 4, Table 4-6).

From the lists of food-web types and their species composition on the Alaskan Shelf in Table A-1, the RAIG can identify some of the types of ecosystems that potentially may be at risk. These include the benthic-pelagic ecosystems of the Kara, Chukchi, Beaufort, and Northern Bering seas and the coastal lagoons along the Alaskan Shelf. The infauna and epifauna of the benthos typically include large numbers of species (see Table A-1). Integrity of the benthos is important not only to provide habitats for the organisms that live there but also for those that depend upon benthic-living organisms for food. Disruption of the benthos may alter significantly prey-predator relationships and competition for ecological niches.

\section{A.4.2 Economically Important Marine Populations at Risk}

An important consideration in Alaska is the loss of fisheries resources directly from adverse effects on economically important species. Food products consumed by the coastal populations in 
the Alaskan Shelf and Northern Bering Sea areas may be very diverse and include most edible materials in their environment. Section 6 provides information about the kinds and parts of food materials consumed. Subsistence harvest patterns of marine foods indicate that marine mammals, fishes, and scabirds and their eggs make up a large fraction of the Native diet. The diet includes piscivorous-feeding mammals (harbor seal, spotted seal, narwhal, beluga whale), benthosfeeding mammals (walrus, bearded seal, gray whalc), a mixed-feeding mammal (ringed seal), a plankton-feeding mammal (bowhead whale), and polar bears. Figures A-1 to A-5 provide information on the food webs of these marine mammals, showing that, except for the bowhead whalc, their food supply depends on the survival of widely diverse groups of organisms. 


\title{
APPENDix B: Radiation Doses and Dose Rates Resulting in Mortality
}

\begin{abstract}
$\mathrm{C}$ onsiderable information is available on the lethal effects of radiation on adult and young organisms from different phyla and different types of ecosystems. Although data are avail able for many species, there are entire phyla and groups within phyla for which none are available. The response to irradiation was expressed frequently as the median lethal dose or $\mathrm{LD}_{50 / 30}$, which is the dose killing $50 \%$ of the population within 30 days.
\end{abstract}

\section{B.1 Radiation Doses Resulting in Mortality}

Comparison of the responses of different species to acute radiation allows the identification of groups of organisms that appear to be more radiosensitive than others. Some representative data on mortality of vertebrate organisms are shown in Table B-1 and for invertebrate organisms in Table B-2. The results show that the range in acute doses that produce mortality in different organisms is very large ( $<3->30,000 \mathrm{~Gy})$, that the ranges in responses overlap, and that among animals, mammals are the most sensitive group. However, there is no indication that doses less than 1 Gy will result in mortality in marine animal groups, including mammals.

Mortality appears to be a very insensitive endpoint for measuring acute radiation effects compared to other endpoints. A study of the sensitivity of endpoints in the worm Neanthes arenaceodentata showed that endpoints characterizing responses at the cellular and molecular levels may indicate better the occurrence of irradiation damage (Table B-3). Also, in quantifying any response, experimental conditions are specially important when poikilothermic species (internal temperature not regulated) are examined. Temperature usually increases radiation sensitivity and lower temperature may slow the rate of development of lesions.

\section{B.2 Radiation Dose Rates Resulting in Mortality}

The chronic effects of radiation on mortality were assessed in some mammalian and nonmammalian species, but the database is limited (ICRP, 1991; Rose, 1992; UNSCEAR, 1993). For Physa heterostropha, decreased survival was reported at dose rates of $0.1 \mathrm{~Gy} / \mathrm{h}$ (Cooley and Miller, 1971) and in adults of the blue crab Callinectes sapidus, dose rates greater than about 0.3 $\mathrm{Gy} / \mathrm{h}$ for $70 \mathrm{~d}$ were required to cause death (Blaylock and Trabalka, 1978). For juveniles of the clam Mercenaria mercenaria dose rates as high as about $0.37 \mathrm{~Gy} / \mathrm{h}$ for 14 months only resulted in decreases in reproduction and growth (Chipman, 1972). For the freshwater cladoceran Daphnia pulex, Marshall (1962) observed increased mortality rates for the population at dose rates $>0.48$ Gy/h. For fishes, Erickson (1973) reported no increase in mortality of the guppy Poecilia reticulata 
exposed to $0.05-1 \mathrm{mCi} \mathrm{mL}^{-1}$ of tritium (total dose of 3.4-47 Gy). For mammals, the highest radiosensitivity was found in the rats Perognathus formosus and Dipodomys microps, which had a doserate limit of less than $0.34-0.68 \mathrm{mGy} / \mathrm{h}$ (Rose, 1992). While the range in dose rates documented to result in mortality is small, $0.1->0.48 \mathrm{~Gy} / \mathrm{h}$, it indicates that dose rates less than $0.1 \mathrm{~Gy} / \mathrm{h}$ will not result in mortality.

Table B-1. Range of $\mathrm{LD}_{50} \mathrm{~s}$ obtained from acute radiation of adult vertebrate organisms from different taxonomic groups.

\begin{tabular}{|c|c|c|}
\hline Phylogenetic Group & Lethal Dose (Gy) & References \\
\hline \multicolumn{3}{|l|}{ Mammals } \\
\hline Humans & 3 & Rice and Baptist (1974) \\
\hline Monkey & 6 & " \\
\hline Dog & 2.5 & $"$ \\
\hline Swine & 2.5 & $"$ \\
\hline Hamster & 6 & $"$ \\
\hline Mouse & 6.4 & $"$ \\
\hline Rabbit & 7.5 & $"$ \\
\hline Bat & 150 & $"$ \\
\hline \multicolumn{3}{|l|}{ Pisces } \\
\hline Goldfish & $3.75-100$ & $\begin{array}{l}\text { Etoh et al., 1974; Shechmeister et al., 1962; } \\
\text { Hyodo-Taguchi, } 1965\end{array}$ \\
\hline Mummichog & $10-20$ & Angelovic et al., 1969 \\
\hline Tench & $12-55$ & Lockner et al., 1972 \\
\hline Guppy & 23.5 & Erickson, 1973 \\
\hline Chinook salmon & 25 & Welander et al., 1948 \\
\hline Mosquitofish & 37 & Blaylock and Mitchell, 1969 \\
\hline Pinfish & 50 & Engel et al., 1967 \\
\hline
\end{tabular}


Table B-2. Range of $\mathrm{LD}_{50} \mathrm{~s}$ obtained from acute radiation of invertebrate organisms from different taxonomic groups.

\begin{tabular}{lcl}
\multicolumn{1}{c}{ Phylogenetic Group } & Lethal Dose (Gy) & \multicolumn{1}{c}{ References } \\
\hline Bacterium & 730,000 & Day and Minton, 1995 \\
Protozoa & $>1,000$ & Bacq and Alexander, 1961 \\
Coelenterata & $20-120$ & in Polikarpov, 1966 \\
Porifera & $20-120$ & in Polikarpov, 1966 \\
Platyhelminthes & 55 & in Polikarpov, 1966 \\
& & \\
Annelida & 100 & Schmidt, 1946 \\
Adult & $>500$ & Harrison and Anderson, 1992 \\
& & \\
Mollusca & 11 & in Blaylock and Trabalka, 1978 \\
Early life & & in Templeton et al., 1971 \\
$\quad$ Adult & $50-500$ & Engel et al., 1974 \\
Crustacea & 2.1 & in Chipman et al., 1972 \\
Adult & $17-100$ & Engel, 1967 \\
Echinodermata & 566 & in Templeton et al., 1971 \\
\hline
\end{tabular}

Table B-3. Comparison of sensitivity of different endpoints for the worm Neanthes arenaceodentata receiving acute irradiation.

\begin{tabular}{cll}
\hline Dose (Gy) & Endpoint & References \\
\hline$>0.3$ & DNA strand breakage & Martinelli et al., 1990 \\
$>0.5$ & $\begin{array}{l}\text { Reduced fertility } \\
\text { Increased sister chromatid exchanges }\end{array}$ & $\begin{array}{l}\text { Harrison and Anderson, 1994a } \\
\text { Harrison et al., 1987 }\end{array}$ \\
$>2$ & Increased chromosomal aberrations & Anderson et al., 1990 \\
$>50$ & Sterility & Harrison and Anderson, 1994a \\
$>100$ & Life-span reduction & Anderson et al., 1990 \\
$>500$ & Mortality & Anderson et al., 1990 \\
\hline
\end{tabular}




\title{
APPENDIX C: INHERENT RADIOSENSITIVITY FACTORS
}

\begin{abstract}
$\mathrm{E}$ cological risk assessment of the Alaskan environment requires an understanding of basic processes that affect radiosensitivity because the responses to radiation of most species in the Arctic have not been characterized. The information reviewed in Section 5 indicates that comparison of responses during reproduction and development represent better the radiosensitivity of the species than the mortality responses of adults. The RAIG needs to recognize factors that may contribute to inherent radiosensitivity in widely diverse group of organisms. Parameters that most likely reflect inherent radiosensitivity include the capabilities for (1) cell repopulation and specialization or differentiation, (2) biological repair, and (3) adaptive responses.
\end{abstract}

\section{C.1 Cell Repopulation and Specialization or Differentiation}

The ability of cells to initiate at any time repopulation of themselves to replace cells damaged or injured by radiation and to cause cell specialization or differentiation to occur undoubtedly is characterized genetically and varies greatly among species. In tissue repair, a number of growthfactor genes are induced that help direct repair. However, the molecular signals that initiate the processes are not established completely but are currently under investigation (Khachigian et al., 1996). The cells involved in repopulation and specialization may be cells that never differentiated, such as primordial germ cells, stem cells, and other types of cells that were "set aside" during early development (Davidson et al., 1995), or cells that had dedifferentiated or transdifferentiated (Patapoutian et al., 1995). If organisms have the abilities to replace cells and to initiate specialization, the radiation damage observed at the whole organism level may be masked. Both these abilities are most likely related to basic developmental processes and pathways and are important components of tissue and organ recovery from radiation damage.

\section{C.2 Biological RePair}

Inherent radiosensitivity is also related to the biological repair capability of cells. Biological repair consists of repair of nuclear as well as cytoplasmic materials. The main focus of repair in the nucleus is on the processes involved in the repair of DNA; that of cellular repair is on the group of enzymes that are involved in the prevention of and in the repair of damaged constituents within the cytoplasm.

The ability of cells to repair radiation damage was noted when organisms were observed to often show reduced sensitivity when exposed to fractionated doses (see reviews Woodhead, 1984; Anderson and Harrison, 1986; NCRP, 1991; and UNSCEAR, 1996). The conclusion is that splitting the dose allows repair processes to reduce the damage. Currently, there is sufficient information to conclude that repair mechanisms are widely distributed and are important to radiosensitivity 
responses. The mechanism receiving the most attention is DNA repair, and an extensive database is available on the genes involved and the processes occurring in a wide variety of organisms (UNSCEAR, 1993; UNSCEAR, 1994).

Indirect damage in genetic material from free radicals produced in the cell's internal milieu from radionuclides accumulated internally is a likely occurrence (Woodhead, 1984; Anderson and Harrison, 1986). Defense mechanisms against the production of free-radical formation were reviewed by Giulio et al. (1989), who were concerned primarily about xenobiotic molecules, such as quinone, aromatic nitro compounds, aromatic hydroxylamines, biphridyls, and certain metal chelates. They proposed that "antioxidant defenses are of three general classes and include water soluble reductants (glutathione, ascorbate, urate), fat-soluble vitamins (alpha-tocopherol, betacarotene) and enzymes (glutathione peroxidase, catalase, superoxide dismutase)." The enzymes are of special interest because they are inducible under conditions of oxidative stress.

Because the kinds and quantities of antioxidant-defense enzymes induced may differ with species, radioresistance in the presence of oxygen may be affected. Therefore, to have a complete understanding of species tolerance to low levels of radiation, it is necessary to consider the capability of the species to reduce concentrations of free radicals by antioxidants. Although little information is known about the role of antioxidants in preventing radiation damage in fishes and invertebrates, some information is available on methods to quantify oxidative stress-related responses induced in these organisms from xenobiotic chemicals (Giulio et al., 1989).

Some information does exist on DNA repair in aquatic organisms. DNA-strand breakage was investigated in freshwater fishes (Shugart, 1988; Shugart et al., 1989) and in a marine bivalve and a polychaete worm (Martinelli et al., 1990). Results from experiments using DNA-strand breakage as the endpoint indicate that after these organisms are irradiated, DNA-strand breakage is repaired. However, the course of repair is much slower in these animals than in mammals; the time of repair takes days rather than hours. Also, little is known about the fidelity of the repair, the capacity of the repair processes, and whether the processes differ among different tissues, e.g., liver as compared to gonads of the organisms. Until more information is known about how effective the DNA repair of radiation damage is in aquatic animals, the importance of the process in ameliorating the adverse effects of radiation remains undefined.

\section{C.3 Adaptive Responses}

Considerable data have accumulated indicating that low doses of radiation may result in changes in the cells that reflect an ability to adapt to the effects of radiation (UNSCEAR, 1993; 1994; Cohen, 1996). This phenomenon is called an "adaptive response," and it may affect our use of the linearno-threshold theory for predicting radiation damage. The response may remain for several hours in mammals and is sometimes referred to as stress response or response to genotoxic stress. In the UNSCEAR report (1994), it is noted that the "conventional estimates of the risks of stochastic effects of low doses on ionizing radiation may have been overstated because no allowance was made for the adaptive response."

Reported manifestations of adaptive responses in mammals are accelerated growth, increased reproductive ability, extended life span, stimulation of the immune system, and reduced incidence of radiation-induced chromosomal aberrations and mutations. The following are some of the mechanisms proposed to be involved in the adaptive response that might be reflected in 
radiosensitivity responses quoted from the UNSCEAR report (1994):

(a) Effects of radiation on the up-regulation of genes and their influence on cell-cycle kinetics;

(b) Identification of activated genes and their enzyme products specifically involved in radiation-induced DNA repair;

(c) Relationship between radiation-induced repair genes and those activated by other mutagens;

(d) Ability of cells to remove toxic radicals;

(e) Activation of membrane receptors and the release of growth factors; and

(f) Effects of radiation on the proliferative response to mitogens.

Although these factors may come into play at low doses and low dose rates, which are characteristic of many of the conditions found in the environment, very little is known about the mechanisms in fishes and invertebrates. The presence of adaptive responses in fauna of concern in our assessment should make our findings even more conservative.

Another important consideration about the adaptive response is that in mammals there is evidence that the lesions induced by radiation also can be induced by some other toxic agents, including physical agents as well as chemical compounds. The adaptive response and its effect on interaction among contaminants in the environment may become an important issue in the future. 


\section{Appendix D: Subsistence DieTs}

nn this report, approximate marine resource dietary reference patterns have been developed
from Alaska Department of Fish and Game (ADF\&G) subsistence studies and previous Alas-
kan and Canadian dietary studies. Reference diets emphasizing seals, walrus, salmon, and
subsistence activities have been developed. Total marine resource consumption levels in the ref-
erence diets range from 72 to $328 \mathrm{~kg} /$ yr. These fall within ranges reported for marine resources
consumption reported in several recent literature reports from Canada (Health Canada, 1995:
Kinloch et al., 1992; Wilimovsky, 1966). These reference dietary patterns provide a realistic range
to assess the radiation dose from the consumption of marine foods. They cannot, though, accu-
rately evaluate an individual or population dose. The reference diets also do not address the
aspect of critical groups that may consume most, if not all, of their foods from local subsistence
resources. Details for each community discussed in Section 6 are provided in Tables D-1 through
D-10. 
Table D-1. Representative diet for Kivalina, Alaska for selected years (Alaska Department of Fish and Game, 1995).

\begin{tabular}{|c|c|c|c|c|c|c|c|}
\hline \multirow{4}{*}{$\begin{array}{l}\text { Marine-Subsistence } \\
\text { Resource }\end{array}$} & \multirow{4}{*}{1992} & \multicolumn{6}{|c|}{ Representative Consumption Rates } \\
\hline & & & Year & & & & rage \\
\hline & & 1983 & 1982 & 1965 & 1963 & & \\
\hline & & \multicolumn{4}{|c|}{ Consumption, $\mathrm{lb} / \mathrm{yr}$} & $\mathrm{lb} / \mathrm{yr}$ & $\mathrm{kg} / \mathrm{yr}$ \\
\hline All Marine-Subsistence Resources & 575.7 & 635.8 & 574.2 & 711.2 & 1127.5 & 724.9 & 328.79 \\
\hline Fish & 252.2 & 200.8 & 181.8 & 141.9 & 393.9 & 234.1 & 106.20 \\
\hline Salmon & 14.8 & 5.4 & 1.7 & 0.5 & 5.7 & 5.6 & 2.55 \\
\hline Chum Salmon & 12.1 & 4.3 & & & & 8.2 & 3.73 \\
\hline Coho Salmon & 0.9 & 0.1 & 1.2 & & & 0.7 & 0.34 \\
\hline Chinook Salmon & 0.4 & & & & & 0.4 & 0.17 \\
\hline Pink Salmon & 1.1 & 0.1 & 0.0 & & & 0.4 & 0.17 \\
\hline Sockeye Salmon & 0.3 & & & & & 0.3 & 0.11 \\
\hline Unknown Salmon & 0.0 & 1.0 & 0.5 & & & 0.5 & 0.23 \\
\hline Non-Salmon Fish & 237.4 & 195.4 & 180.1 & 141.4 & 388.2 & 228.5 & 103.64 \\
\hline Herring & 0.4 & 0.1 & & & & 0.2 & 0.10 \\
\hline Cod & 17.7 & 11.1 & 0.0 & 28.0 & & 14.2 & 6.45 \\
\hline Char & 203.0 & 177.5 & 179.0 & 113.2 & 378.1 & 210.2 & 95.34 \\
\hline Grayling & 1.9 & 2.5 & 0.8 & 0.2 & & 1.3 & 0.60 \\
\hline Sheefish & 0.2 & & & & & 0.2 & 0.09 \\
\hline Whitefish & 13.6 & 4.2 & 0.3 & 0.1 & 10.1 & 5.6 & 2.55 \\
\hline Cisco & 0.6 & & & & & 0.6 & 0.26 \\
\hline Marine Mammals & 317.4 & 433.0 & 391.3 & 569.1 & 727.8 & 487.7 & 221.24 \\
\hline Polar Bear & 2.5 & 2.9 & & 2.8 & & 2.7 & 1.24 \\
\hline Seal & 185.6 & 100.1 & 217.6 & 440.2 & 675.2 & 323.7 & 146.85 \\
\hline Bearded Seal & 156.6 & 73.6 & 168.5 & 235.9 & 295.1 & 185.9 & 84.34 \\
\hline Ribbon Seal & 0.9 & & 0.3 & & & 0.6 & 0.28 \\
\hline Ringed Seal & 22.0 & 26.2 & 48.4 & 203.7 & 377.8 & 135.6 & 61.51 \\
\hline Spotted Seal & 6.1 & 0.3 & 0.4 & 0.6 & 2.3 & 2.0 & 0.89 \\
\hline Walrus & 61.7 & 13.3 & 14.2 & 18.8 & & 27.0 & 12.24 \\
\hline Whale & 67.6 & 316.7 & 159.4 & 107.4 & 52.6 & 140.7 & 63.84 \\
\hline Beluga & 29.0 & 166.3 & 159.4 & 107.4 & 52.6 & 103.0 & 46.70 \\
\hline Bowhead & 38.5 & 146.7 & & & & 92.6 & 42.01 \\
\hline Gray Whale & & 3.7 & & & & 3.7 & 1.68 \\
\hline Birds and Eggs & 6.0 & 2.0 & 1.1 & 0.1 & 5.7 & 3.0 & 1.36 \\
\hline Migratory Birds & 1.5 & 1.5 & 0.3 & & & 1.1 & 0.51 \\
\hline Eider & 1.5 & 1.5 & 0.3 & & & 1.1 & 0.51 \\
\hline Bird Eggs & 4.5 & 0.5 & 0.8 & 0.1 & 5.7 & 2.3 & 1.05 \\
\hline Seabird \& Loon Eggs & 2.3 & 0.2 & 0.4 & 0.1 & 2.9 & 1.2 & 0.53 \\
\hline Gull Eggs & 0.2 & 0.0 & 0.0 & & & 0.1 & 0.04 \\
\hline Murre Eggs & 2.0 & 0.2 & 0.4 & 0.1 & 2.9 & 1.1 & 0.50 \\
\hline Marine Invertebrates & 0.1 & & & & & 0.1 & 0.04 \\
\hline Crabs & 0.0 & & & & & 0.0 & 0.00 \\
\hline Tanner Crab & 0.0 & & & & & 0.0 & 0.00 \\
\hline Shrimp & 0.1 & & & & & 0.1 & 0.03 \\
\hline
\end{tabular}

D-2 
Table D-2. Representative diet for Emmonak, Alaska for 1980 (Alaska Department of Fish and Game, 1995).

Marine-Subsistence Resource

Representative Consumption Rates

\begin{tabular}{llr} 
& $\mathrm{lb} / \mathrm{yr}$ & $\mathrm{kg} / \mathrm{yr}$ \\
\hline All Resources & 546.26 & 247.78 \\
Fish & 399.89 & 181.39 \\
Salmon & 226.04 & 102.53 \\
Chum Salmon & 131.70 & 59.74 \\
Coho Salmon & 14.64 & 6.64 \\
Chinook Salmon & 79.70 & 36.15 \\
Non-Salmon Fish & 173.85 & 78.86 \\
Tom Cod & 7.99 & 3.62 \\
Sheefish & 71.41 & 32.39 \\
Whitefish & 61.79 & 28.03 \\
Cisco & 32.66 & 14.81 \\
Marine Mammals & 94.52 & 42.87 \\
Seal & 42.67 & 19.36 \\
Bearded Seal & 12.10 & 5.49 \\
Ringed Seal & 18.82 & 8.54 \\
Spotted Seal & 11.75 & 5.33 \\
Whale & 51.85 & 23.52 \\
Beluga & 51.85 & 23.52 \\
& & \\
\hline
\end{tabular}


Table D-3. Representative diet for Point Lay, Alaska for 1987 (Alaska Department of Fish and Game, 1995).

Representative Consumption Rates

\begin{tabular}{lll} 
Marine-Subsistence Resource & $\mathrm{lb} / \mathrm{yr}$ & $\mathrm{kg} / \mathrm{yr}$ \\
\hline All Resources & 679.77 & 308.34 \\
Fish & 24.75 & 11.23 \\
Salmon & 3.52 & 1.60 \\
Chum Salmon & 2.01 & 0.91 \\
Pink Salmon & 1.51 & 0.68 \\
Non-Salmon Fish & 21.23 & 9.63 \\
Herring & 0.04 & 0.02 \\
Sinelt & 0.31 & 0.14 \\
Flounder & 0.80 & 0.36 \\
Char & 4.58 & 2.08 \\
Grayling & 14.81 & 6.72 \\
Sheefish & 0.00 & 0.00 \\
Whitefish & 0.69 & 0.31 \\
Marine Mammals & 637.42 & 289.13 \\
Polar Bear & 5.48 & 2.49 \\
Seal & 55.24 & 25.06 \\
Bearded Seal & 19.42 & 8.81 \\
Ringed Seal & 17.23 & 7.82 \\
Spotted Seal & 18.59 & 8.43 \\
Walrus & 38.18 & 17.32 \\
Whale & 538.52 & 244.27 \\
Beluga & 538.52 & 244.27 \\
Bowhead & 0.00 & 0.00 \\
Birds and Eggs & 17.60 & 7.98 \\
Migratory Birds & 8.74 & 3.96 \\
Eider & 8.74 & 3.96 \\
Seabirds \& Loons & 0.06 & 0.03 \\
Murre & 0.06 & 0.03 \\
\hline
\end{tabular}

D-4 
Table D-4. Representative diet for Barrow, Alaska for the years 1987-1989 (Alaska Department of Fish and Game, 1995).

\begin{tabular}{|c|c|c|c|c|c|}
\hline \multirow[b]{2}{*}{$\begin{array}{c}\begin{array}{c}\text { Marine-Subsistence } \\
\text { Resource }\end{array} \\
\end{array}$} & \multirow[b]{2}{*}{$1987 \mathrm{C}$} & \multicolumn{2}{|l|}{ Years } & \multicolumn{2}{|c|}{ Average Intake Rates } \\
\hline & & \multicolumn{2}{|c|}{$\begin{array}{c}1988 \\
\text { Consumption, lb/yr }\end{array}$} & $\mathrm{lb} / \mathrm{yr}$ & $\mathrm{kg} / \mathrm{yr}$ \\
\hline All Resources & 134.59 & 129.33 & 211.01 & 158.3 & 71.81 \\
\hline Fish & 27.17 & 16.33 & 38.25 & 27.2 & 12.36 \\
\hline Salmon & 0.38 & 0.17 & 4.04 & 1.5 & 0.69 \\
\hline Chum Salmon & 0.02 & 0.01 & 1.04 & 0.4 & 0.16 \\
\hline Coho Salmon & 0.2 & 0.14 & 1.65 & 0.7 & 0.30 \\
\hline Chinook Salmon & 0.02 & 0.01 & 0.19 & 0.1 & 0.03 \\
\hline Pink Salmon & 0.01 & & 0.27 & 0.1 & 0.06 \\
\hline Unknown Salmon & 0.13 & 0.01 & 0.89 & 0.3 & 0.16 \\
\hline Non-Salmon Fish & 26.79 & 16.16 & 34.21 & 25.7 & 11.67 \\
\hline Smelt & 0.27 & & 0.08 & 0.2 & 0.08 \\
\hline Capelin (grunion) & 0.26 & & 0.02 & 0.1 & 0.06 \\
\hline Rainbow Smelt & 0.01 & & 0.06 & 0.0 & 0.02 \\
\hline Cod & 0 & 0.59 & 1.13 & 0.6 & 0.26 \\
\hline Arctic Cod & 0 & 0.53 & 1.13 & 0.6 & 0.25 \\
\hline Pacific Tom Cod & 0 & 0.06 & & 0.0 & 0.01 \\
\hline Char & 0.03 & 0.07 & 0.13 & 0.1 & 0.03 \\
\hline Arctic Char & 0.03 & 0.07 & 0.13 & 0.1 & 0.03 \\
\hline Grayling & 3.36 & 2.3 & 2.23 & 2.6 & 1.19 \\
\hline Cisco & 8.9 & 2.54 & 1.44 & 4.3 & 1.95 \\
\hline Bering Cisco & 1.4 & 0.05 & 0.47 & 0.6 & 0.29 \\
\hline Least Cisco & 7.5 & 2.49 & 0.97 & 3.7 & 1.66 \\
\hline Whitefish & 14.23 & 10.66 & 29.21 & 8.0 & 8.18 \\
\hline Broad Whitefish & 9.12 & 9.76 & 26.17 & 15.0 & 6.81 \\
\hline Humpback Whitefish & 1.02 & 0.54 & 3.02 & 1.5 & 0.69 \\
\hline Round Whitefish & 0.7 & 0.24 & 0.01 & 0.3 & 0.14 \\
\hline Unknown Whitefish & 3.39 & 0.12 & & 1.8 & 0.80 \\
\hline Marine Mammals & 104.85 & 110.76 & 168.5 & 128.0 & 58.08 \\
\hline Polar Bear & 1.9 & 1.87 & 6.46 & 3.4 & 1.55 \\
\hline Seal & 20.29 & 15.88 & 10.97 & 15.7 & 7.13 \\
\hline Bearded Seal & 13.77 & 10.42 & 6.35 & 10.2 & 4.62 \\
\hline Ringed Seal & 6.49 & 5.41 & 4.57 & 5.5 & 2.49 \\
\hline Spotted Seal & 0.03 & 0.05 & 0.05 & 0.0 & 0.02 \\
\hline Walrus & 21.44 & 15.65 & 25.86 & 21.0 & 9.52 \\
\hline Whale & 61.22 & 77.36 & 125.21 & 87.9 & 39.89 \\
\hline Beluga & 0 & & & 0.0 & 0.00 \\
\hline Bowhead & 61.22 & 77.36 & 125.21 & 87.9 & 39.89 \\
\hline Birds and Eggs & 2.57 & 2.24 & 4.26 & 3.0 & 1.37 \\
\hline Eider & 2.57 & 2.24 & 4.26 & 3.0 & 1.37 \\
\hline Common Eider & 0 & 0.01 & 0.03 & 0.0 & 0.01 \\
\hline King Eider & 0.04 & 0.01 & 0.05 & 0.0 & 0.02 \\
\hline Spectacled Eider & 0 & & & 0.0 & 0.00 \\
\hline Steller Eider & 0 & & & 0.0 & 0.00 \\
\hline Unknown Eider & 2.53 & 2.22 & 4.18 & 3.0 & 1.35 \\
\hline
\end{tabular}


Table D-5. Consumption of subsistence food for Broughton Island, NWT (Health Canada, 1995).

\begin{tabular}{lcc} 
& Adult & Critical Group \\
\multicolumn{1}{c}{ Source } & & $\mathrm{kg} / \mathrm{y}$ \\
\hline Fish & 66.4 & 85 \\
Marine Mammals & 301 & 390 \\
Large Land Mammals & 64.1 & 90 \\
Small Animals & 3.1 & 5.8 \\
Totals & 434.6 & 570.8 \\
\hline
\end{tabular}

Table D-6. Estimated food consumption of adults living in coastal villages of the 1960s (from Wilimovsky and Wolfe, 1966).

\begin{tabular}{lccccc}
\hline \multicolumn{5}{c}{ Season } \\
\hline Item & Spring & Summer & $\begin{array}{c}\text { Fall } \\
\text { Amount Consumed, } \mathrm{kg}\end{array}$ \\
\hline Caribou & & & & Winter & Annual \\
Fish & 76.7 & 45.5 & 45.5 & 76.7 & 244.4 \\
Ugruk & 23.4 & 23.4 & 27.3 & 23.4 & 97.5 \\
Seals & 14.3 & 15.6 & 14.3 & 12.35 & 56.55 \\
Fowl & 7.67 & 7.02 & 5.33 & 10.01 & 30.03 \\
Walrus & 11.18 & 5.85 & 5.85 & 5.85 & 28.73 \\
Whale & 0 & 0 & 0 & 0 & 0 \\
Rabbit & 5.33 & 0 & 0 & 0 & 5.33 \\
Berries & 0 & 0 & 0 & 0 & 0 \\
Murre Eggs & 0 & 7.02 & 0 & 0 & 7.02 \\
Bear & 0 & 18.2 & 0 & 0. & 18.2 \\
Crab & 0 & 0 & 0 & 0 & 0 \\
Total Native & 130.8 & 0 & 13 & 13 & 39 \\
Native \& Store & 369.2 & 235.3 & 110.5 & 140.4 & 497.9 \\
\hline
\end{tabular}


Table D-7. Estimated food consumption of adults living in Point Hope, Alaska in the 1960s (from Wilimovsky and Wolfe, 1966).

\begin{tabular}{|c|c|c|c|c|c|}
\hline \multirow[b]{3}{*}{ Item } & \multicolumn{4}{|c|}{ Season } & \multirow{3}{*}{ Annual } \\
\hline & Spring & Summer & Fall & Winter & \\
\hline & \multicolumn{4}{|c|}{ Amount Consumed, $\mathrm{kg}$} & \\
\hline Caribou & 39 & 20.8 & 26 & 40.3 & 126.1 \\
\hline Fish & 5.85 & 26 & 28.6 & 24.7 & 85.15 \\
\hline Ugruk & 19.5 & 11.18 & 11.83 & 19.5 & 62.01 \\
\hline Seals & 26 & 16.9 & 20.8 & 19.5 & 83.2 \\
\hline Fowl & 9.49 & 16.9 & 5.85 & 5.85 & 38.09 \\
\hline \multicolumn{6}{|l|}{ Walrus } \\
\hline Whale & 20.8 & 13 & & & 33.8 \\
\hline \multicolumn{6}{|l|}{ Rabbit } \\
\hline Berries & & 7.02 & & & 7.02 \\
\hline Murre Eggs & & 18.2 & & & 18.2 \\
\hline Bear & & & & 7.02 & 7.02 \\
\hline \multicolumn{6}{|l|}{ Crab } \\
\hline Total Native & 124.8 & 135.2 & 100.1 & 114.4 & 474.5 \\
\hline Native \& Store & 254.8 & 275.6 & 204.1 & 235.3 & 969.8 \\
\hline
\end{tabular}

Table D-8. Estimated food consumption of adults living in Barrow, Alaska in the 1960s (from Wilimovsky and Wolfe, 1966).

\begin{tabular}{|c|c|c|c|c|c|}
\hline \multicolumn{6}{|c|}{ Season } \\
\hline & Spring & Summer & Fall & Winter & Annual \\
\hline Item & \multicolumn{5}{|c|}{ Amount Consumed, $\mathrm{kg}$} \\
\hline$\overline{\text { Caribou }}$ & 15.6 & 16.9 & 15.6 & 16.9 & 65 \\
\hline Fish & 11.83 & 12.35 & 13 & 13 & 50.18 \\
\hline Ugruk & 7.02 & 7.02 & 5.33 & 7.67 & 27.04 \\
\hline Seals & 6.5 & 6.5 & 5.33 & 7.67 & 26 \\
\hline Fowl & 4.68 & 6.5 & 5.33 & 5.33 & 21.84 \\
\hline Walrus & 4.68 & 4.68 & 5.33 & 5.33 & 20.02 \\
\hline Whale & 10.01 & 0 & & & 10.01 \\
\hline \multicolumn{6}{|l|}{ Rabbit } \\
\hline Berries & & 0 & & & 0 \\
\hline Murre Eggs & & 0 & & & 0 \\
\hline Bear & 0.65 & & & 0 & 0.65 \\
\hline \multicolumn{6}{|l|}{ Crab } \\
\hline Total Native & 61.1 & 53.3 & 50.7 & 57.2 & 222.3 \\
\hline Native \& Store & 192.4 & 167.7 & 156 & 176.8 & 692.9 \\
\hline
\end{tabular}


Table D-9. Estimated food consumption by adults living in Diomede, Alaska in the 1960s (from Wilimovsky and Wolfe, 1966).

\begin{tabular}{|c|c|c|c|c|c|}
\hline & \multicolumn{4}{|c|}{ Season } & \multirow{3}{*}{ Annual } \\
\hline & Spring & Summer & Fall & Winter & \\
\hline Item & \multicolumn{4}{|c|}{ Amount Consumed, $\mathrm{kg}$} & \\
\hline Caribou & 0 & 23.4 & 0 & 5.85 & 29.25 \\
\hline Fish & 0.585 & 0 & 0 & 13 & 13.585 \\
\hline Ugruk & 31.2 & 20.8 & 20.8 & 29.9 & 102.7 \\
\hline Seals & 31.2 & 20.8 & 20.8 & 29.9 & 102.7 \\
\hline Fowl & 24.7 & 8.84 & 0 & 0 & 33.54 \\
\hline Walrus & 28.6 & 26 & 26 & 26 & 106.6 \\
\hline Whale & 13 & 0 & & & 13 \\
\hline \multicolumn{6}{|l|}{ Rabbit } \\
\hline Berries & & 0 & & & 0 \\
\hline Murre Eggs & 14.3 & 14.3 & & & 28.6 \\
\hline Bear & & & & 0 & 0 \\
\hline Crab & & & & 8.84 & 8.84 \\
\hline Total Native & 143 & 114.4 & 67.6 & 113.1 & 438.1 \\
\hline Native \& Store & 187.2 & 150.8 & 88.4 & 149.5 & 575.9 \\
\hline
\end{tabular}

Table D-10. Estimated food consumption of adults living in Kotzebue, Alaska in the 1960s (from Wilimovsky and Wolfe, 1966).

\begin{tabular}{|c|c|c|c|c|c|}
\hline \multirow[b]{3}{*}{ Item } & \multicolumn{4}{|c|}{ Season } & \multirow{3}{*}{ Annual } \\
\hline & Spring & Summer & Fall & Winter & \\
\hline & \multicolumn{4}{|c|}{ Amount Consumed, $\mathrm{kg}$} & \\
\hline Caribou & 37.7 & 35.1 & 37.7 & 37.7 & 148.2 \\
\hline Fish & 18.2 & 18.2 & 18.2 & 19.5 & 74.1 \\
\hline Ugruk & 10.66 & 8.84 & 5.85 & 12.35 & 37.7 \\
\hline Seals & 8.32 & 7.02 & 7.02 & 12.35 & 34.71 \\
\hline Fowl & 8.84 & 5.85 & 8.32 & 11.83 & 34.84 \\
\hline \multicolumn{6}{|l|}{ Walrus } \\
\hline Whale & 13 & 13 & & & 26 \\
\hline Rabbit & & & & 2.47 & 2.47 \\
\hline Berries & 4.68 & 10.66 & 4.68 & 7.67 & 27.69 \\
\hline Murre Eggs & & 0 & & & 0 \\
\hline Bear & & & & 0 & 0 \\
\hline \multicolumn{6}{|l|}{ Crab } \\
\hline Total Native & 100.1 & 98.8 & 81.9 & 105.3 & 386.1 \\
\hline Native \& Store & 345.8 & 339.3 & 280.8 & 362.7 & 1328.6 \\
\hline
\end{tabular}




\section{APPENDIX E: WORKSHEET FOR ESTIMATING INDIVIDUAL Doses}

Tection 6 provided information about reference diets in the various selected villages along the Alaskan coast. Individuals in these villages who desire a better understanding of their own potential dose may use the following worksheet. To use the worksheet, a person must first total his or her annual input of the various food types. Then, the user must determine which of the RAIG-model water concentrations best fits his or her own location. With these two pieces of information, the user can make a simple calculation to estimate annual dose.

Information is provided so that individuals can estimate their own doses from Russian sources (dumping and riverine releases), from historical fallout, and from natural sources. It is anticipated that assistance from local health care personnel may be required.

\section{Dose Estimation Worksheet}

Location Selected

Time Period Selected

Amount consumed per year $\times$ (Pounds)

Fish

Mammals

Birds/Eggs

Mollusks

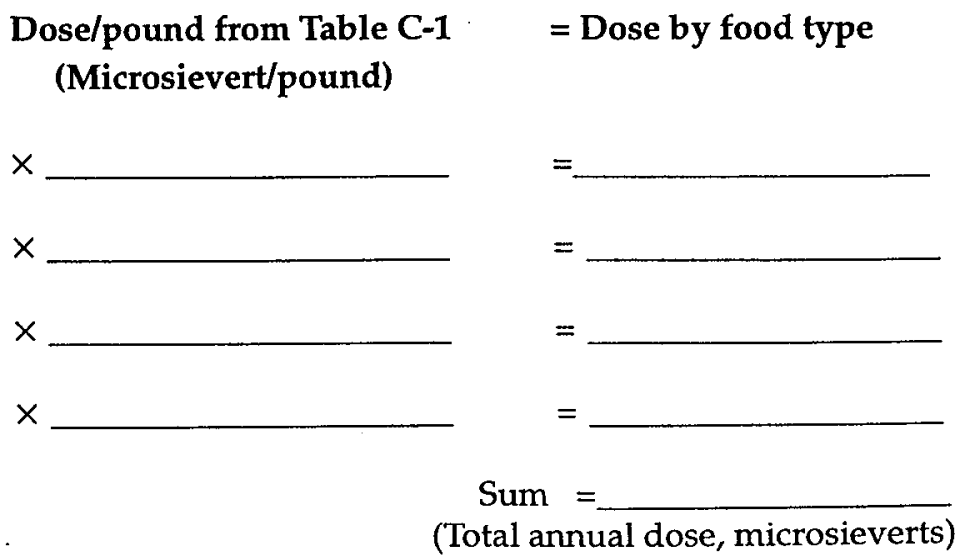

(Total annual dose, microsieverts) 
Step 1: Estimate the total amount of each of the following types of foods, in pounds, that you eat in one year.

Fish (for instance: salmon, herring, cod, char, grayling, sheefish, whitefish)

$\mathrm{lb}$ per year

Marine mammals (for instance: polar bear, seal, walrus, whale, etc.)

$\mathrm{lb}$ per year

Birds and eggs (for instance, meat or eggs from eider, loon, duck, gull, murre)

lb per year

Marine invertebrates (for instance: crab, shrimp, clams, mussels)

lb per year

Step 2: Determine which of the three locations applies best to your home; Beaufort Sea, Chukchi Sea, or Bering Sea. If you live near the dividing line between two of these locations, try taking the northernmost one to obtain a higher estimate. You can determine which of these is most appropriate by looking at the map (Figure 6-1 in Section 6).

Step 3: Fill in the worksheet with the number of pounds per year that you eat, and the "dose per pound" value from Table E-1 for the time period and location you are interested in. Multiply each pair of values together, and then add up the total. This is your individual radiation dose estimate in units of $\mu$ Svs from that source. If you want to know your total dose from all sources, repeat the calculation for natural background and anthropomorphic (man-made fallout) background, and add these results to the result for the former Soviet dumping source.

Note for Table E-1: When numbers are very large or very small, we present them using scientific notation. Scientific notation is a type of shorthand for numbers. For example, we could write the number 1 billion as $1,000,000,000$ or using scientific notation, as $1 \times 10^{9}$. To translate from scientific notation to a traditional number, move the decimal point either left or right from the number. For example, if the value given is $2.0 \times 10^{3}$, move the decimal point three numbers (insert zeros if no numbers are given) to the right of its present location. The number would then read 2,000. If the value given is $2.0 \times 10^{-5}$, move the decimal point five numbers to the left of its present position (0.00002). As a special case, a number such as $1.3 \times 10^{\circ}$, when the rule is followed, simply becomes 1.3.

E-2 
Table E-1. Estimation of individual radiation doses for Alaskan coastal communities located adjacent to the Beaufort, Bering, and Chukchi seas.

Radiation Dose per Pound of Food Eaten, $\mu \mathrm{Sv} / \mathrm{lb}$

\begin{tabular}{|c|c|c|c|}
\hline \multirow[b]{3}{*}{ Source/Food Item } & Time Period & \multirow{2}{*}{\multicolumn{2}{|c|}{ Peak Projected Concentration }} \\
\hline & $1960 \mathrm{~s}$ & & \\
\hline & & Beaufort Sea & Chukchi Sea \\
\hline
\end{tabular}

Kara Sea Instantaneous Release

$\begin{array}{llllll}\text { Fish } & - & - & 2.4 \times 10^{-5} & 1.0 \times 10^{-5} & 1.5 \times 10^{-7} \\ \text { Mammals } & - & - & 2.1 \times 10^{-5} & 9.5 \times 10^{-6} & 1.3 \times 10^{-7} \\ \text { Birds/Eggs } & - & - & 5.5 \times 10^{-5} & 2.4 \times 10^{-5} & 3.5 \times 10^{-7} \\ \text { Mollusks } & - & - & 4.7 \times 10^{-4} & 1.5 \times 10^{-4} & 2.1 \times 10^{-6}\end{array}$

\section{Kara Sea Time-Varying Release}

Fish

Mammals

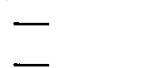

$-\quad 4.8 \times 10^{-7}$

$4.6 \times 10^{-7}$

$2.2 \times 10^{-7}$

$4.6 \times 10^{-9}$

Birds/Eggs

$=\quad \overline{-}$

$1.1 \times 10^{-6}$

$2.1 \times 10^{-7}$

$4.3 \times 10^{-9}$

Mollusks

$-\quad-\quad 7.1 \times 10^{-7}$

$1.4 \times 10^{-5}$

$1.0 \times 10^{-8}$

$2.9 \times 10^{-6}$

$6.0 \times 10^{-9}$

\section{Accidental Riverine Sources}

Fish

Mammals

Birds/Eggs

Mollusks

$\begin{array}{lll}- & - & 2.8 \times 10^{-6} \\ - & - & 1.1 \times 10^{-6} \\ - & - & 4.6 \times 10^{-5} \\ - & - & 7.2 \times 10^{-7}\end{array}$

$1.3 \times 10^{-6}$

$5.1 \times 10^{-7}$

$1.8 \times 10^{-8}$

$2.1 \times 10^{-5}$

$6.8 \times 10^{-9}$

$3.3 \times 10^{-7}$

$3.1 \times 10^{-7}$

Chronic Riverine Sources

$\begin{array}{llllll}\text { Fish } & - & & 1.1 \times 10^{-6} & 4.8 \times 10^{-7} & 1.0 \times 10^{-8} \\ \text { Mammals } & - & - & 2.9 \times 10^{-7} & 1.3 \times 10^{-7} & 2.8 \times 10^{-9} \\ \text { Birds/Eggs } & - & - & 2.1 \times 10^{-5} & 9.5 \times 10^{-6} & 2.0 \times 10^{-7} \\ \text { Mollusks } & - & - & 2.6 \times 10^{-7} & 1.2 \times 10^{-7} & 2.5 \times 10^{-9}\end{array}$

Existing Anthropomorphic Background*

$\begin{array}{llllll}\text { Fish } & 9.5 \times 10^{-3} & 1.3 \times 10^{-3} & 1.3 \times 10^{-3} & 1.3 \times 10^{-3} & 1.3 \times 10^{-3} \\ \text { Mammals } & 9.0 \times 10^{-3} & 1.3 \times 10^{-3} & 1.3 \times 10^{-3} & 1.3 \times 10^{-3} & 1.3 \times 10^{-3} \\ \text { Birds/Eggs } & 1.9 \times 10^{-2} & 2.3 \times 10^{-3} & 2.3 \times 10^{-3} & 2.3 \times 10^{-3} & 2.3 \times 10^{-3} \\ \text { Mollusks } & 3.7 \times 10^{-2} & 4.0 \times 10^{-3} & 4.0 \times 10^{-3} & 4.0 \times 10^{-3} & 4.0 \times 10^{-3}\end{array}$

Natural Background

Fish

$4.9 \times 10^{-1} \quad 4.9 \times 10^{-1}$

$4.2 \times 10^{-1}-4.2 \times 10^{-1}$

$4.9 \times 10^{-1}$

$4.2 \times 10^{-1}$

$4.9 \times 10^{-1}$

$4.2 \times 10^{-1}$

$4.9 \times 10^{-1}$

$7.4 \times 10^{0}$

$7.4 \times 10^{0}$

$7.4 \times 10^{0}$

$4.2 \times 10^{-1}$

Birds/Eggs

$7.4 \times 10^{0}$

$7.4 \times 10^{0}$

$7.4 \times 10^{0}$

$7.4 \times 10^{0}$

$7.4 \times 10^{0}$

$7.4 \times 10^{0}$

* Existing anthropomorphic background (fallout) will continue to decrease in the future with an approximate 30 -year half-life. The peak value given corresponds to current conditions. 


\section{GLOSSARY}

7 This report contains many terms referring to various units of radioactivity and dose as well as different types of radionuclides. Listed below are many of the terms frequently used in the text.

Actinide Elements: A group of rare earth elements starting with thorium, Th (atomic number 90) and continuing through lawrencium, $\mathrm{Lw}$ (atomic number 103). Uranium, $U$ (atomic number 92), and plutonium, $\mathrm{Pu}$ (atomic number 94) are members of this group.

Activation Products: Products formed by the incorporation of slow neutrons into the nuclei of atoms, which therefore increase by one mass number. Neutron activation is a means of artificially producing radioisotopes for industrial, scientific, and medical purposes. Examples are ${ }^{60} \mathrm{Co}$ (cobalt) and ${ }^{59} \mathrm{Fe}$ (iron).

Alpha Particle: A positively charged particle emitted from the nucleus of an atom that consists of two protons and two neutrons. The alpha particle is identical to the helium nucleus.

Becquerel (Bq): Unit of radioactivity. It is equal to one nuclear disintegration per second, $(3.7 \times$ $\left.10^{10} \mathrm{~Bq}=1 \mathrm{Ci}\right)$.

Benthic (benthos): Biota living on or closely associated with the bottom of a body of water.

Beta Particle: A particle (negative electron) emitted from the nucleus of an atom. Its emission from the nucleus is accompanied by another particle, the neutrino, which has no electrical charge and a vanishingly small mass.

BIORAD: An ecological model.

Collective Dose Equivalent (S): A quantity that relates the total exposure of a group of individuals to a particular source of radiation exposure. It can be defined as $S=\sum_{i} H_{i} N(H)_{i}$, where $\mathrm{N}(\mathrm{H})_{i}$ is the number of individuals in population subgroup $i$, receiving an average dose equivalent of $H_{i}$ The collective dose equivalent is a quantity that can be used in cost-benefit analyses for the purpose of justification and optimization; its unit is the man-Sv.

CRITR: An ecological model.

Curie (Ci): An older unit of radioactivity. It is defined as that quantity of any radionuclide undergoing $3.7 \times 10^{10}$ disintegrations per second. The choice of this figure is the result of an original definition based on the activity of a sample of ${ }^{226} \mathrm{Ra}$.

Dyne: In the cgs (centimeter, gram, second) system, unit force is the force that will accelerate a 1 -gram mass at $1 \mathrm{~cm} / \mathrm{s}^{2}$, called the dyne. 
Effective Dose Equivalent $\left(H_{E}\right)$ : A sum derived by $H_{E}=\Sigma_{T} W_{T} H_{T}$, where $W_{T}$ is a weighting factor and $\mathrm{H}_{\mathrm{T}}$ is the dose equivalent in tissue $\mathrm{T}$. The summation is carried out over the same period for all tissues. The effective dose equivalent acts as an indicator of the death risk from somatic effects, and of hereditary effects in the first two generations, which are assumed to result from any radiation, whether uniform or nonuniform, from both internal and external sources. It is not a complete indicator of health effects, and does not include hereditary effects in subsequent generations.

Erg: A unit of work in the cgs (centimeter, gram, second) system; 1 erg = 1 dyne-centimeter.

EXTREM III: An ecological model.

Fission: The splitting of an atom. The fission process usually is accompanied by the emission of neutrons and much more rarely by the emission of alpha particles and possibly other light fragments.

Fission Products: Radionuclides arising from fission, both the primary fission fragments and the radionuclides resulting from their decay. Examples are ${ }^{137} \mathrm{Cs}$ (cesium) and ${ }^{90} \mathrm{Sr}$ (strontium).

Furfurol (F): Epoxy resin used to fill and seal reactor compartments.

Gamma Ray: Electromagnetic radiation emitted from the nucleus when an atom is in transition from a higher to a lower energy state.

Gray (Gy): The unit of absorbed dose equal to 1 Joule per kilogram, (1 Gy =100 rad).

Half-Life: The time required for any given amount of radionuclide to decay to one-half of its original amount. The half-life of a radionuclide is a unique and reproducible characteristic of that radionuclide.

Inherent Radiosensivity Factors: Factors that are controlled by the genetic makeup of an organism and that determine basic developmental processes and pathways and biologicalrepair processes.

Joule (J): A unit of work in the $m k s$ (meter, kilogram, second) system. $1 \mathrm{~J}=10^{7}$ ergs $=0.7376 \mathrm{ft}-\mathrm{lb}$.

Nekton: Biota swimming on or near the surface of a body of water.

Pelagic (pelagos): Biota living in or near surface waters distant from land.

Phytoplankton: Microscopic plant life floating or drifting in a body of water.

Planktivorous: Biota that feed on plankton.

Point Source Dose Distribution (PSDD): An ecological dosimetry model.

Polynya: An area of open water in sea ice.

Rad: An older unit of absorbed dose, cqual to 100 ergs per gram.

Radiation Quality Factor: Relative biological effectiveness. 
Radioisotope Thermoelectric Generator: A device for producing electricity from the heat produced during radioactive decay of a radionuclide source.

Rem: (Roentgen equivalent man): An older unit of dose equivalent. It is that amount of any type of radiation producing the same biological effect as is obtained from an absorbed dose of 1 rad of $200 \mathrm{KVP} X$-rays. A roentgen is the amount of ionizing radiation that will produce $2.58 \times$ $10^{-4}$ coulomb of electric charge in $1 \mathrm{~kg}$ of dry air.

Sievert (Sv): The unit of dose equivalent. $(1 \mathrm{~Sv}=100 \mathrm{rem})$.

Source Term: The inventory of radionuclides at a given source available for release into the environment.

Weighting Factors $\left(\mathrm{W}_{\mathrm{T}}\right)$ : Factors representing the proportion of the probabilistic risk resulting from irradiation of tissue $\mathrm{T}$ to the total risk when the whole body is irradiated uniformly.

Zooplankton: Microscopic animal life swimming or drifting in a body of water. 
REFERENCES

Aagaard, K., and P. Greisman, 1975: Toward new mass and heat budgets for the Arctic Ocean. J. Geophys. Res., 80, 3821-3827.

Aarkrog, A., 1994: Radioactivity in polar regions, main sources. J. Environ. Radioactivity, 25, $21-35$.

S. Boelskifte, H. Dahlgaard, S. Duniec, E. Holm, J. N. Smith, 1987: Studies of transuranics in an Arctic marine environment. J. Radioanalytical and Nuclear Chem., Articles, 115 (1), 39-50.

M. S. Baxter, A. O. Bettencourt, R. Bojanowski, A. Bologa, S. Charmasson, I. Cunha, R. Delfanti, E. Duran, E. Holm, R. Jeffree, H. D. Livingston, S. Mahapanyawong, H. Nies, I. Osvath, L. Pingyu, P. P. Provinec, A. Sanchez, J. N. Smith, and D. Swift, 1997: A comparison of doses from ${ }^{137} \mathrm{Cs}$ and ${ }^{210} \mathrm{Po}$ in marine food: a major international study. J. Environ. Radioactivity, 34, 69-90.

Alaska Department of Community and Regional Affairs, cited 1990: Community profiles, 1990 Census Data. [Available on-line from http://www.comregaf.state.ak.us/cis_cont.htm.]

Anderson, S. L., and F. L. Harrison, 1986: Effects of radiation on aquatic organisms and radiobiological methodologies for effects assessment. EPA Rep. EPA 520/1-85-016, U. S. Environmental Protection Agency, Washington, DC 20460.

and and G. Chan, and D. H. Moore II, 1990: Comparison of cellular and wholeanimal bioassays for estimation of radiation effects in the polychaeta worm Neanthes arenaceodentata (Polychaeta). Arch. Environ. Contam. Toxicol., 19, 164-174.

Angelovic, J. W., J. C. White, Jr., and E. M. Davis, 1969: Interactions of ionizing radiation and temperature on the estuarine fish, Fundulus heteroclitus. Proc. Second National Symposium on Radioecology, Nelson, D. J. and F. C. Evans, Eds., CONF-670503, U.S. Atomic Energy Commission, 131-141.

Bacon, M. P., C.-A. Huh, and R. M. Moore, 1989: Vertical profiles of some natural radionuclides over the Alpha Ridge. Earth Planet. Sci. Lett., 95, 15-22.

Bacq, Z. M., and P. Alexander, 1961: Fundamentals of Radiobiology. Pergamon Press, Oxford, England.

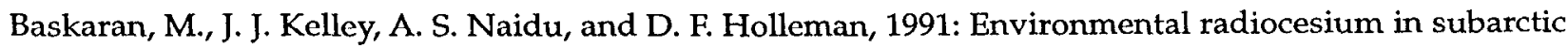
and Arctic Alaska following Chernobyl. Arctic, 44, 346-350.

S. Asbill, P. Santschi, T. Davis, J. Brooks, M. Champ, V. Makeyev, and V. Khlebovich, 1995: Distribution of ${ }^{239,240} \mathrm{Pu}$ and ${ }^{238} \mathrm{Pu}$ concentrations in sediments from the $\mathrm{Ob}$ and Yenisey Rivers and the Kara Sea. Appl. Radiat. Isot., 46, 1109-1119. 
and and and J. Brooks, M. Champ, d. Adkinson, M. R. Colmer, and V. Makeyev, 1996: Pu, ${ }^{137} \mathrm{Cs}$ and excess ${ }^{210} \mathrm{~Pb}$ in the Russian Arctic sediments. Earth Planet. Sci. Lett., 140, 243-257.

and A. S. Naidu, 1995: ${ }^{210} \mathrm{~Pb}$-derived chronology and the fluxes of ${ }^{210} \mathrm{~Pb}$ and ${ }^{137} \mathrm{Cs}$ isotopes into continental shelf sediments, East Chukchi Sea, Alaskan Arctic, Geochim. Cosmochim. Acta, 59, 44354448 .

Beasley, T. M., L. W. Cooper, J. M. Grebmeier, and L. R. Kilius, 1995: Iodine-129 in western Arctic waters. Proc. Second International Conference on Environmental Radioactivity in the Arctic, Oslo, Norway, Scientific Committee of the Environmental Radioactivity in the Arctic, 121.

Becker, P. R., 1994: Characterization of the Arctic environment. Arctic Res., 8, 66-76.

Blaylock, B. G., and T. J. Mitchell, 1969: The effect of temperature on the dose response of Gambusia affinus affinus from two natural populations. Radiat. Res., 40, 503-511.

and J. R. Trabalka, 1978: Evaluating the effects of ionizing radiation on aquatic organisms. Vol. 7, Advances in Radiation Biol., J. T. Lett and H. Adler, Eds., Academic Press, 103-109.

Bobkin, V. I., and N. N. Bobrovitskaya, 1995: SHI/USGS Database. State Hydrological Institute, St. Petersburg, Russia.

Bonham, K., and A. D. Donaldson, 1972: Sex ratios and retardation of gonadal development in chronically gamma-irradiated Chinook salmon smolts. Trans. Am. Fish Soc., 101, 428-434.

Bowen, V. T., and T. T. Sugihara, 1964: Fission product concentration in the Chukchi Sea. J. Arctic Inst. of North America, 17(3), 198-203.

Bradley, D. J., and U. P. Jenquin, 1995: Radioactive inventories and sources for contamination of the Kara Sea by riverine transport. PNNL Rep. PNWD-2316, Pacific Northwest National Laboratory, Richland, WA.

Bryan, K., 1984: Accelerating the convergence to equilibrium of ocean-climate models. J. Phys. Oceanogr., 14, 666-673.

Buesseler, K. O., and E. R. Sholkovitz, 1987: The geochemistry of fallout plutonium in the North Atlantic: I. A pore water study in shelf, slope, and deep-sea sediments. Geochim. Cosmochim. Acta, 51, $2605-2622$.

Busby, B., cited 1996: Radiation and Health Physics Home Page. [Available on-line from http:// www.sph.umich.edu/group/eih/UMSCHPS/risk.htm].

Carroll, J., F. Boisson, S. W. Fowler, and J.-L. Teyssie, 1997: Radionuclide adsorption to sediments from nuclear waste dumping sites in the Kara Sea. Mar. Poll. Bull., (in press).

and I. H. Harms, 1997: The importance of sediment/water partition coefficients in modeling the transport of radionuclides released from a nuclear waste site in the Russian Arctic. Env. Sci. Technol., (submitted Nov. 1996).

Carvalho, F. P., 1988. ${ }^{210}$ Po in marine organisms: a wide range of natural radiation dose domains. $R$ adiat. Prot. Dosim., 24, 113-117.

R-2 
Chartier, M., 1993: Radiological Assessment of Dumping in the Kara and Barents Seas: Design of a Compartmental Box Structure for the Arctic Ocean and Surrounding Oceans. Ivry sur Seine, France, Cabinet d'Etudes Techniques et d'Innovations Scientifiques.

Cheng, A., and R. Preller, 1996: The development of an ice-ocean coupled model in the northern hemisphere. Rep. NRL/FR/7322-95-9627, Naval Research Laboratory, Stennis Space Center, MS.

Chipman, W. A., 1972: Ionizing radiation. Vol. 1., Marine Ecology, O. Kinne, Ed., John Wiley/Interscience, 1579-1657.

Chumichev, V. B., 1995: Sr-90 discharge with main rivers of Russia into the Arctic Ocean during 1961-1990. Proc. Second Conference on Environmental Radioactivity in the Arctic, Oslo, Norway, Scientific Committee of the Environmental Radioactivity in the Arctic, 79-84.

Clark, M. J., and G. A. M. Webb, 1981: A model to assess exposure from releases of radioactivity into the seas of northern Europe. Proc. Impacts of Radionuclide Releases into the Marine Environment, Vienna, Austria, International Atomic Energy Agency (IAEA-SM-248/103), 629-488.

Cochran J. K., N. S. Fischer, and S. B. Moran, 1996: Transport and fate of radionuclides in the Ob river estuarine system. Arctic Nuclear Waste Assessment Program Summary fiscal ycar 1995, ONR Rep. 32296-16, Office of Naval Research, Arlington, VA, 62-76.

Codispoti, L. A., G. E. Friederich, C. M. Sakamoto, and L. I. Gordon, 1991: Nutrient cycling and primary production in the marine systems of the Arctic and Antarctic. J. Mar. Sci., 2, 359-384.

Cohen, B. L., 1996: Test of the linear-no-threshold theory for radiation carcinogenesis for inhaled radon decay products. Health Phys., 68, 157-172.

Committee on the Biological Effects of Ionizing Radiations, 1988: Health Risks of Radon and Other Internally Deposited Alpha-Emitters (BEIR IV). National Academy Press, Washington, DC.

1990: Health Effects of Exposure to Low Levels of Ionizing Radiation (BEIR V). National Academy Press, Washington, DC.

Cooley, J. L., and F. L. Miller, Jr., 1971: Effects of chronic irradiation on laboratory populations of the aquatic snail PHYSA heterostropha. Radiat. Res., 47, 716-724.

Cooper, L. W., I. L. Larsen, T. M. Beasley, S. S. Dolvin, J. M. Grebmeier, J. M. Kelley, M. Scott, and A. JohnsonPyrtle, 1997: The distribution of radiocesium and plutonium in sea ice-entrained Arctic sediments in relation to potential sources and sinks. Deep-Sea Res., (submitted, Sept. 96).

J. M. Grebmeier, I. L. Larsen, C. Solis, and C. R. Olsen, 1995: Fvidence for redistribution of cesium-137 in Alaskan tundra, lake, and marine sediments. Sci. Total Environ., 160/161, 295-306.

Cox, M., 1984: A primitive equation, 3-dimensional model of the ocean. GFDL Ocean Group Tech. Rep. 1, Geophysical Fluid Dynamics Laboratory, Princeton, NJ.

Danilyan, V. A., and V. A. Vysotsky, 1995: Nuclear waste disposal practices in Russia's Pacific Ocean. Arctic Research of the United States, Vol. 9, Proc. Japan-Russia-United States Study Group on Dumped Nuclear Waste in the Sea of Japan, Sea of Okhotsk, and the North Pacific Ocean, Molnia, B., Ed., Japan-United States Friendship Commission and the Office of Naval Research, 84-87. 
Davidson, E. H., K. J. Peterson, and R. A. Camerson, 1995: Origin of bilaterian body plans: evolution of developmental regulatory mechanisms. Science, 270, 1319-1325.

Day, M. J., and K. W. Minton, 1995: Resistance to radiation. Science, 270, 1318.

Dayton, P. K., B. J. Mordida, and F. Bacon, 1994: Polar marine communities. Amer. Zool., 34, 90-99.

Decisioneering, Inc., 1993: Crystal Ball for Windows. Decisioneering, Inc., Boulder, CO.

Duursma, E. K., and J. Carroll, 1996: Environmental Compartments, Equilibria, and Assessments of Processes Between Air, Water, Sediments, and Biota. Springer.

Dyer, R., Ed.: Low-level liquid radioactive waste treatment at Murmansk, Russia: Technical design and review of facility upgrade and expansion, Rep. BNL-TR-52505, Brookhaven National Laboratory, Upton, NY.

Eckerman, K. F., A. B. Wolbarst, and A. C. B. Richardson, 1988: Limiting values of radionuclide intake and air concentration and dose conversion factors for inhalation, submersion, and ingestion. EPA Rep. EPA-520/1-88-020, U. S. Environmental Protection Agency, Washington, DC 20460.

Edson, R., M. Varela, and T. Joya, 1996: Department of Defense Arctic Nuclear Waste Assessment Program Summary, fiscal year 1995. ONR Rep. 33-96-16, Office of Naval Research, Arlington, VA.

Egami, N. and K. I. Ijuri, 1979: Effects of irradiation on germ cells and embryonic development in teleost. Int. Rev. Cytol., 59, 195-248.

Ellis, K. M., J. N. Smith, R. P. Nelson, L. Kilius, R. Macdonald, E. Carmack, S. B. Moran, 1995: Distribution of artificial radionuclides in the Arctic Ocean from the 1994 Arctic Ocean section. Proc. Second International Conference on Environmental Radioactivity in the Arctic, Oslo, Norway, Scientific Committee of the Environmental Radioactivity in the Arctic, 204-207.

Engel, D. W., J. W. Angelovic, and E. M. Davis, 1967: Effects of Acute Irradiation on the Blood of Pin Fish. U.S. Fish and Wildlife Service.

M. G. Shelton, and J. C. White, 1974: The effect of ionizing radiation and salinity on the grass shrimp Palaemonetes pugio. Radiat. Res., 59, 72.

Erickson, R. C., 1973: Effects of chronic irradiation by tritiated water on Poecilia reticulata, the guppy. Proc. Third National Symposium on Radioecology, CONF-710501, D. J. Nelson, Ed., Washington, DC, U. S. Atomic Energy Commission, 1091-1099.

Etoh, H., Y. Hyodo-Taguchi, and T. Maruyama, 1974: Mortality response of goldfish after exposure to fast neutrons. J. Radiat. Res., 9, 141.

Evans, S., 1985: A box model for calculation of collective dose commitment from radioactive waterborne releases to the Baltic Sea. J. Environ. Radioactivity, 2, 41-57.

Feder, H. M., N. R. Foster, S. C. Jewett, T. J. Weingartner, and R. Baxter, 1994: Mollusks in the northeastern Chukchi Sea. Arctic, 47(2), 145-163. 
Fuhrmann, M., H. Zhou, J. Neiheisel, J. A. A. Schoonen, and R. Dyer, 1996: Sorption/desorption of radioactive contaminants by sediment from the Kara Sea. Sci. Total Environ. (In press).

Gehrs, C. W., J. R. Trabalka, and E. A. Bardill, 1975: Sensitivity of adult and embryonic calanoid copepods to acute ionizing radiation. Radiat. Res., 63, 382-385.

Giulio, R. T., P. C. Washburn, R. J. Wenning, G. W. Winston, and C. S. Jewell, 1989: Biochemical responses in aquatic animals: a review of determinants of oxidative stress. Environ. Tox. Chem., 8, 1103-1123.

Gobas, F. A. P. C., M. N. Z'Graggen, and X. Zhang, 1995: Time response of the Lake Ontario ecosystem to virtual elimination of PCBs. Environ. Sci. Technol., 29,2038-2046.

Gomez, L. S., M. G. Marietta, and D. W. Jackson, 1991: Compilation of selected marine radioecological data for the Formerly Utilized Sites Remedial Action Program: summaries of available radioecological concentration factors and biological half-lives, Sandia Rep. SAND89-1585, Sandia National Laboratories, Albuquerque, NM.

Gray, J., S. R. Jones, and A. D. Smith, 1995: Discharges to the environment from the Sellafield site, 19511992. J. Radiol. Prot., 15, 99-131.

Grebmeier, J. M., H. M. Feder, and C. P. McRoy, 1989: Pelagic-benthic coupling on the shelf of the northern Bering and Chukchi Seas, II. Benthic community structure. Mar. Ecol.: Prog. Ser., 51, 253-268.

and J. P. Barry, 1991: The influence of oceanographic processes on pelagic-benthic coupling in polar regions: a benthic perspective. J. Mar. Sys., 2, 498-518.

Greenberger, J. S., J. Pechenik, A. Lord, L. Gould, E. Naparstek, K. Kase, and T. J. Fitzgerald, 1986: X-irradiation effects on growth and metamorphosis of gastropod larvae (Crepidula fornicata): A model for environmental radiation teratogenesis. Arch. Enviro. Contamination and Toxicology, 15, 227-234.

Guegueniat, P., P. B. DuBois, and R. Gandon, 1995: Estimation of La Hague contribution to the artificial radioactivity of Norwegian water (1992-1996) and Barents Sea (1992-1997). Proc. Second International Conference on Environmental Radioactivity in the Arctic, Oslo, Norway, Scientific Committee of the Environmental Radioactivity in the Arctic, 102-107.

Hallstadius, L., A. Aarkrog, H. Dahlgaard, E. Holm, S. Boelskifte, S. Duniec, and B. Persson, 1986: Plutonium and americium in Arctic waters, the North Sea, and Scottish and Irish coastal zones. J. Environ. Radioactivity, 4, 11-30.

E. Garcia-Montano, U. Nilsson, and S. Boelskifte, 1987: An improved and validated dispersion model for the North Sea and adjacent waters. J. Environ. Radioactivity, 5, 261-274.

Hamilton, T. F., S. Ballestra, M. S. Baxter, J. Gastaud, I. Osvath, P. Parsi, P. P. Povinec, and E. M. Scott, 1994: Radiometric investigations of Kara Sea sediments and preliminary radiological assessment related to dumping of radioactive wastes in the Arctic Seas. J. Environ. Radioactivity, 25, 113-134.

Harcharek, R. C., 1995: North Slope Borough 1993/94 Economic Profile and Census Report, Vol. 2. North Slope Borough Department of Planning and Community Services. 
Harrison, F. L., 1986: Laboratory-determined concentration factors and elimination rates of some anthropogenic radionuclides in marine vertebrates and invertebrates. EPA Rep. 5201/1-85-015, U.S. Environmental Protection Agency, Washington, DC 20460.

D. Rice Jr., D. Moore II, and M. Varela, 1987: Effects of radiation on frequency of chromosomal aberrations and sister chromatid exchange in Neanthes arenaceodentata. Vol. 1, Oceanic Processes on Marine Pollution, J. M. Capuzzo and D. R. Kester, Eds., Krieger, 146-156.

and Anderson, S. L., 1994a: The effects of acute irradiation on reproductive success of the polychaete worm Neanthes arenaceodentata. Radiat. Res., 137, 59-66.

and 1994b: Effects of chronic irradiation on the reproductive success of the polychaete worm, Neanthes arenaceodentata. Radiation Research, 140, 401-409.

Health Canada, 1995: Review of human exposure to environmental radiation in the Canadian Arctic (1995). Contract No. H4078-4-C786/01-SS, Beak Consultants.

Herrmann, J., P. J. Kershaw, P. B. duBois, and P. Guegueniat, 1995: The distribution of artificial radionuclides in the English Channel, Southern North Sea, Skagerrak, and Kattegat, 1990-1993. Marine Sys., $6,427-456$.

Hibler, W. D. III, 1979: A dynamic thermodynamic sea ice model. J. Phys. Oceanogr., 9, 815-864. 1980: Modeling a variable thickness sea ice cover. Mon. Wea. Rev., 108, 1943-1973.

Highsmith, R. C. and K. O. Coyle, 1990: High productivity of northern Bering Sea amphipods. Nature , 344, 862-864.

Hileman, B., 1996: Environmental hormone disrupters focus of major research initiatives. Chem. Eng. News, May 13, 1996, 28-35.

Holm, E., A. Aarkrog, S. Ballestra, and H. Dahlgaard, 1986: Origin and isotopic ratios of plutonium in the Barents and Greenland Seas. Earth and Planetary Sci. Lett., 79, 27-32.

Holton, R. L., W. O. Forster, and C. L. Osterberg, 1973: The effect of gamma irradiation on the reproductive performance of Artemia as determined by individual pair matings. Proc. Symposium on Radiation in Ecosystems. Oak Ridge, TN, U. S. Atomic Energy Commission, 1191-1197.

Holtzman, R. B., 1980: Normal dietary levels of radium-226, radium-228, lead-210, and polonium-210 for man. Vol. 1, Natural Radiation Environment III, DOE Rep. CONF-780422, F. Gesell and W. M. Lowder., Eds., U.S. Department of Energy, Washington, DC, 755-782.

Hoppenheit, M., 1973: Effects of fecundity and fertility of single sublethal x-irradiation of Gammarus duebeni females. Proc. Symposium on Radioactive Contamination of the Marine Environment. Vienna, Austria, International Atomic Energy Agency, 479-486.

House of Commons Defense Committee, 1990: Decommissioning of nuclear submarines. 7th Report to Session 1988-1989, Her Majesty's Stationary Office, London, England.

Hunt, G. J., 1984: Simple models for prediction of external radiation exposure from aquatic pathways. Radiat. Prot. Dos., 8 (4), 215-224.

R-6 
1992: External doses to the public from beta emitters in the aquatic environment near Springfields and Sellafield. J. Radiol. Prot., 12 (4), 233-238.

Hyodo-Taguchi, Y., 1965: Effect of X-irradiation on the intestinal epithelium of the goldfish Carassius auratus: II. Influence of temperature on the development of histopathological changes in the intestine. Radiat. Res., 24, 133-141.

1980: Effects of chronic gamma-irradiation on spermatogenesis in the fish, Oryzias latipes, with special reference to regeneration of testicular stem cells. Radiation Effects on Aquatic Organisms. N. Egami, Ed., University Park Press, Baltimore, MD, 91-104.

International Atomic Energy Agency, 1978: The radiological basis for the IAEA revised definition and recommendations concerning high-level radioactive waste unsuitable for dumping at sea, IAEA Tech. Rep. No. IAEA-TECDOC-211, IAEA, Vienna, Austria.

1985: Sediment $K_{d} s$ and concentration factors for radionuclides in the marine environment. IAEA Tech. Rep. No. 247, IAEA, Vienna, Austria.

1988: Assessing the impact of deep sea disposal of low-level radioactive waste on living marine resources. IAEA Tech. Rep. No. 288, IAEA, Vienna, Austria.

1997: Predicted radionuclide release from marine reactors dumped in the Kara Sea. SourceTerm Working Group of the International Arctic Seas Assessment Project (IASAP), Tech. Rep. Series No. TECDOC-938, IAEA, Vienna, Austria.

International Commission on Radiation Protection, 1990: 1990 recommendations of the International Commission on Radiation Protection, ICRP Pub. 60, Pergamon Press, New York, NY.

1991: Recommendations of the Commission. ICRP.

1994: Age-dependent doses to members of the public from intakes of radionuclides: Part 2, Ingestion dose coefficients. ICRP Publication 67, Annals of the ICRP, Vol. 23, No. 3/4, ICRP, Oxford, England.

Ivanov, V., 1994: Working material of the International Arctic Seas Assessment Project (IASAP), sedimentological description of the Barents and Kara Seas. IAEA Rep. IAEA-IASAP-3, International Atomic Energy Agency, Vienna, Austria.

Jackson, D. W., L. S. Gomez, and M. G. Marietta, 1983: Compilation of selected marine radioecological data for the U. S. Subseabed Program. Sandia Rep. SAND83-1725, Unlimited Release, Sandia Laboratory, Albuquerque, NM, UC-70.

Jiang, T.-N., Lord, B. I., and Hendry, J. H., 1994: Alpha particles are extremely damaging to developing hemopoiesis compared to gamma irradiation. Radiat. Res., 137: 380-384.

Kempema, E. W., E. Reimnitz, et al., 1989: Sea ice sediment entrainment and rafting in the Arctic. J. Sediment. Petrol., 59, 308-317.

Kershaw, P. J., and A. Baxter, 1995: The transfer of reprocessing wastes from northwest Europe to the Arctic. Deep-Sea Res. II, 42, 1413-1448. 
D. S. Woodhead, M. B. Lovett, and K. S. Leonard, 1995: Plutonium from European reprocessing operations-its behaviour in the marine environment. Appl. Radiat. Isot., 46, 1121-1134.

Khachigian, L. M., V. Lindner, J. A. Williams, and T. Collins, 1996: EGR-1-induced endothelial gene expression, a common theme in vascular injury. Science, 271, 1427-1431.

Kilius, L. R., X.-L. Zhao, J. N. Smith, and K. M. Ellis, 1995: The measurement of I-129 in the Canadian Arctic Basin. Second International Conference on Environmental Radioactivity in the Arctic, Oslo, Norway, Scicntific Committee of the Environmental Radioactivity in the Arctic, 117-120.

Kinloch, D., 1992: Inuit food and diet: a preliminary assessment of benefits and risks. Sci. of the Total Environ., 122, 247-278.

Knowles, J. F., and I. N. Greenwood, 1994: The effects of chronic irradiation on the reproductive performance of Ophryothrocha diadema (Polychaeta, Dorvilleidae). Mar. Environ. Res., 38, 207-224.

Konno, K., 1980: Effects of gamma-irradiation on the gonads of the rainbow trout, Salmo gairdnerii irideus, during embryonic stages. Radiation Effects on Aquatic Organisms, N. Egami, Ed., University Park Press, Baltimore, MD, 129-133.

Lawton, E. C., R. J. Fragaszy, and M. D. Hetherington, 1992: Review of wetting-induced collapse in compacted soil. J. Geotech. Engineering, 118, 1376-1394.

Livingston, H. D., V. T. Bowen, S. A. Casso, H. L. Volchok, V. E. Noshkin, K. M. Wong, and T. M. Beasley, 1985: Fallout nuclides in Atlantic and Pacific water columns. GEOSECS Data Rep. WHOI-85-19, Woods Hole Oceanographic Institution.

Lockner, D., A. Petterson, and U. Ericson, 1972: Radiosensitivity of haemopoiesis in fish studies at $18^{\circ}$ and $10^{\circ}$ C. J. Radiat Biol., 21, 559-572.

Marietta, M. G., and W. F. Simmons, 1988: Feasibility of disposal of high-level radioactive waste into the seabed. Vol.5, Dispersal of Radionuclides in the Oceans: Models, Data Sets and Regional Descriptions, Nuclear Energy Agency, Paris, France.

Marshall, J. S., 1962: The effects of continuous gamma radiation on the intrinsic rate of natural increase of Daphnia pulex. Ecology, 43, 598-607.

Martinelli, R. E., J. P. Knezovich, and F. L. Harrison, 1990: Radiation-induced DNA strand breakage and repair in the marine polychaete Neathes arenaceodentata. Mar. Env. Res., 28, 329-332.

McPhee, M. G., 1990: Small-scale processes. Polar Oceanography; Part A, Physical Science,_W. O. Smith, Jr., Ed., Academic Press, San Diego, CA, 287-334.

Medinets, V. I., V. G. Soloviev, and B. V. Glebov, 1992: Investigation of cesium-137 Distribution in Seawater. Results of the Third Joint Bering and Chukchi Seas Expedition (BERPAC), Summer 1988, P.A. Nagel, Ed., U. S. Fish and Wildlife Service, 327-329.

Meese, D., L. Cooper, I. L. Larsen, W. Tucker, E. Reimnitz, J. Grebmeier, 1995: Cesium ${ }^{137}$ contamination in Arctic sea ice. Proc. Second International Conference on Environmental Radioactivily in the Arctic, Oslo, Norway, Scientific Committee of the Environmental Radioactivity in the Arctic, 195-198. 
Meese, D., A. E. Reimnitz, W. B. Tucker, A. J. Gow, J. Bischof, and D. Darby, 1997: Evidence for radionuclide transport by sea ice. Sci. Total Environ., (in press).

Miyake, Y., and Y. Sugimura, 1976: The plutonium content of Pacific Ocean waters. Transuranium Nuclides in the Environment, IAEA Rep. IAEA-SM-199/22, International Atomic Energy Agency, Vienna, Austria, 91-105.

Morgan, J., and L. Codispoti, 1995: Department of Defense Arctic nuclear waste assessment program summary, fiscal years 1993 and 1994. ONR Rep. 322-95-5, Office of Naval Research, Arlington, VA.

Mount, M. E., N. M. Lynn, and J. M. Warden, 1996: Predicted radionuclide release from reactor-related unenclosed solid objects dumped in the sea of Japan and the Pacific Ocean, East Coast of Kamchatka. LLNL Rep. UCRL-JC-124351, Lawrence Livermore National Laboratory, Livermore, CA. [Submitted to Proc. Global Partnership: A Multi-National Workshop on Nuclear Waste in and Around the Sea of Japan, Sea of Okhotsk, and the North Pacific Ocean, Nigata, Japan.]

M. K. Sheaffer, and D. T. Abbott, 1994: Fstimated inventory of radionuclides in Former Soviet Union naval reactors dumped in the Kara Sea. Arctic Res. of the United States, 8,160-178.

Nagaya, Y., and K. Nakamura, 1984: ${ }^{239,240} \mathrm{Pu},{ }^{137} \mathrm{Cs}$ and ${ }^{90} \mathrm{Sr}$ in the central north Pacific. J. Oceanographical Soc. of Japan, 40, 416-424.

National Council on Radiation Protection and Measurements, 1991: Effects of ionizing radiation on aquatic organisms, NCRP Rep. 109, NCRP, Bethesda, MD.

National Council on Radiation Protection and Measurements, 1993: Risk estimates for radiation protection, Rep. 115, NCRP, Bethesda, MD.

National Radiological Protection Board, 1993: Estimates of late radiation risks to the U.K. population, Documents of the NRPB, Vol. 4, No. 4, NRPB, Chilton, Didcot, England.

Nielsen, S. P., 1995: A box model for northeast Atlantic coastal waters compared with radioactive tracers. J. Marine Sys., 6, 545-560.

M. Iosjpe, and P. Strand, 1995: A Preliminary assessment of potential doses to man from radioactive waste dumped in the Arctic Sea, Rep. No. Risö-R-841(EN), Risö National Laboratory, Roskilde, Denmark.

Nikitin, A. I., I. Y. Katrich, A. I. Kabanov, V. B. Chumichev, and V. M. Smagin, 1991: Radioactive contamination of the Arctic Ocean, based on observations in 1985-1987. Vol. 71, Soviet Atomic Energy, Plenum Publishing Corporation, 687-690.

Nilsen, T., and N. Bohmer, 1994: Sources of radioactive contamination in Murmansk and Arkangel'sk counties. Vol. 1, Bellona Rep., Bellona Foundation, Oslo, Norway.

J. Kudrik, and A. Nikitin, 1996: The Russian northern fleet. Vol. 2, Bellona Rep., Bellona Foundation, Oslo, Norway.

Nobmann, E. A. D. , 1996: Diet among Siberian Yup'iks of Alaska and the Implications for Cardiovascular Disease. Thesis, University of Alaska, Fairbanks, AK. 
Noshkin, V. E., K. M. Wong, R. J. Eagle, and T. A. Jokela, 1984: Concentrations of ${ }^{207} \mathrm{Bi}$ and ${ }^{210} \mathrm{~Pb},{ }^{210} \mathrm{Bi}$, ${ }^{210} \mathrm{Po}$ disequilibrium in fish. Pac. Sci., 38, 350-355.

1985: Concentrations and concentration factors of several anthropogenic and natural radionuclides in marine vertebrates and invertebrates, LLNL Rep. UCRL-91766, Lawrence Livermore National Laboratory, Livermore, CA, EPA Rep. 520/1/84/028, U. S. Environmental Protection Agency, Washington, DC 20460.

W. L. Robison, and K. M. Wong, 1994: Concentrations of ${ }^{210} \mathrm{Po}$ and ${ }^{210} \mathrm{~Pb}$ in the diet at the Marshall Islands. Sci. Total Environ., 155, 87-104.

Nurnberg, D. I., D. Wollenburg, et al., 1994: Sediments in Arctic sea ice: implications for entrainment, transport and release. Mar. Geol., 119, 185-214.

Ostlund, H. G. and G. Hut, 1984: Arctic Ocean water balance from isotope data. J. Geophys. Res., 89, 63736381.

Patapoutian, A., B. J. Wold, and R. A. Wagner, 1995: Evidence for developmentally programmed transdifferentiation in mouse esophageal muscle. Science, 270, 1818-1820.

Pavlov, V. K., L. A. Timokhov, G. A. Baskakov, M. Y. Kulakov, V. K. Kurazhov, P. V. Pavlov, S. V. Pivovarov, and V. V. Stanovoy, 1996: Hydrometerorological regime of the Kara, Laptev, and East-Siberian Seas. Applied Physics Laboratory, University of Washington, Seattle, WA.

Pfirman, S. L., H. Eicken, D. Bauch, and W. F. Weeks, 1995: The potential transport of pollutants by Arctic sea ice. Sci. Total Environ., 159, 129-146.

Pfirman, S. L., J. W. Kogeler, and I. Rigor (accepted), 1997: Research note: Potential shortcuts for transport of contaminants from the Kara Sea. Sci. Total Environ.

M. A. Lange, et al., 1990: Sea ice characteristics and the role of sediment inclusions in deep-sea deposition: Arctic-Antarctic comparisons. Geological History of the Polar Oceans: Arctic v. Antarctic. U. Bleil and J. Theide, Eds., Kluwer Academic Publishers, 187-211.

Polikarpov, G. G., 1966: Radioecology of Aquatic Organisms. Pergamon Press, Oxford, England.

Povinec, P. P., M. S. Baxter, et al., 1996: IAEA-MEL contribution to the IASAP report. Final Report on the IAEA International Arctic Seas Assessment Program Rep., International Atomic Energy Agency, Vienna, Austria, (in press).

Puskin, J., and C. Nelson, 1994: Estimating radiogenic cancer risks. EPA 402-R-93-076, U.S. Environmental Protection Agency, Washington, DC.

Radioactive Waste Management Center, 1996: Concentration factors of radionuclides in the marine organisms. Environmental Parameter Series 6, RWMC Rep. RWMC-96-P-18, RWMC, Japan.

Raisbeck, G. M., F. Yiou, Z. Q. Zhou, and L. R. Kilius, 1995: ${ }^{129} \mathrm{I}$ as a tracer of reprocessing discharges in the Arctic Oceans. Proc. Second International Conference on Environmental Radioactivity in the Arctic, Oslo, Norway, Scientific Committee of the Environmental Radioactivity in the Arctic. 
Ravera, O., 1966: Effects of x-irradiation on various stages of the life cycle of (Physa acuta, Daparnaud) a fresh-water gastropod. Proc. Symposium on Disposal of Radioactive Wastes into Seas, Oceans, and Surface Waters. Vienna, Austria, International Atomic Energy Agency, 799-808.

1967: The effect of x-rays on the demographic characteristics of Physa acuta (Gastropoda: Basommatophora). Malacologia, 5, 95-109.

Reimnitz, E. M., K. McCormick, et al., 1993: Sediment export by ice rafting from a coastal polynya, Arctic Alaska, USA. Arctic and Alpine Res., 25 (2), 83-98.

Rice, T. R., and J. P. Baptist, 1974: Ecologic effects of radioactive emissions from nuclear power plants. Human and Ecological Effects of Nuclear Power Plants, L. A. Sagin, Ed., C. C. Thomas, Springfield, IL, 373-439.

Rigor, I., and R. Colony, 1997: Sea ice production and transport of pollutants in the Laptev Sea, 1979-1992, Sci. Total Environ. (accepted).

Roach, A. T., K. Aagaard, C. H. Pease, S. A. Salo, T. Weingartner, V. Pavlov, and M. Kulakov, 1995: Direct measurements of transport and water properties through the Bering Strait, J. Geophys. Res., 100, 18, $443-18,457$.

Roos, P., E. Holm, R. B. R. Persson, and S. P. Nielsen, 1992: Flux of ${ }^{210} \mathrm{~Pb},{ }^{137} \mathrm{Cs},{ }^{239,240} \mathrm{Pu}$, and ${ }^{241} \mathrm{Am}$ in the Antarctic Peninsula area. Nordic Liason Committee for Nuclear Science Meeting.

Rose, K. S. B., 1992: Lower limits of radiosensitivity in organisms, excluding man. J. Environ. Radioactivity, $15,113-133$.

Rubtsov, P., and P. Ruzhansky, 1995: Radiation Characteristic Estimation of Irradiated Nuclear Fuel in Reactors of Nuclear Submarine and Icebreaker Lenin Dumped Near Novaya Zemlya Archipelago. State Institute for Applied Ecology, Ministry of Environmental Protection and Natural Resources of the Russian Federation, Moscow, Russia.

Sarmiento, J. L., and K. P. Brian, 1982: An ocean transport model for the north Atlantic. J. Geophys. Res., 87, $395-408$.

Savinova, T. N., G. W. Gabrielsen, and S. Falk-Petersen, 1995: Chemical pollution in the Arctic and subArctic marine ecosystems: an overview of current knowledge. Joint Norwegian-Russian Commission on Environmental Cooperation, Seabird Expert Group.

Schlosser, P., J. H. Swift, et al., 1995: The role of the large-scale Arctic Ocean circulation in the transport of conlaminants. Deep-Sea Res. II, 42, 1341-1367.

Scott, C. L., el al., 1995: Community Profile Database Catalog. Alaska Department of Fish and Game (ADF\&G), Division of Subsistence.

Shechmeister, I. L., L. J. Watson, V. W. Cole, and L. L. Jackson, 1962: The effect of x-irradiation of goldfish: effect of $x$-irradiation on survival and susceptibility of the goldfish, Carassius auratus, to infection by Aeromonas salmonicida and Gyrodactylus spp. Radiat. Res., 16, 89-97.

Shinohara, K., and T. Asano, 1992: Environmental dose assessment for low-level radioactive effluents discharged from Tokai reprocessing plant. Health Phys., 62 (1), 58-64. 
Shugart, L., 1988: Quantization of chemically induced damage to DNA of aquatic organisms by alkaline unwinding assay. Aquatic Toxicol., 13, 43-52.

M. Gustin, D. Laird, and D. Dean, 1989: Susceptibility of DNA in aquatic animals to strand breakage: effect of $\mathrm{x}$-ray and gamma radiation. Mar. Environ. Res., 28, 339-343.

Sivintsev, Y., 1993: Study of nuclides composition and characteristics of fuel in dumped submarine reactors and atomic icebreaker "Lenin": Part 1, Atomic icebreaker. Russian Research Center, Kurchatov Institute Rep., Moscow, Russia.

August 1994: Study of nuclides composition and characteristics of fuel in dumped submarine reactors and atomic icebreaker "Lenin": Part 2, Nuclear submarines. Russian Research Center Rep. No. 31/7281, Kurchatov Institute, Moscow, Russia.

1995: Description of shielding barriers at the nuclear reactors dumped in the Arctic, IAEA-IASAPReport No. 8, Russian Research Center Kurchatov Institute, [Moscow, Russia].

March 1995: Personal communication. Russian Research Center, Kurchatov Institute, Moscow, Russia.

September 1995: Personal communication. Russian Research Center, Kurchatov Institute, Moscow, Russia.

October 1995: Personal communication. Russian Research Center, Kurchatov Institute, Moscow, Russia.

December 1995: Personal communication. Russian Research Center, Kurchatov Institute, Moscow, Russia.

Smith, J. N., K. M. Ellis, A. Aarkrog, H. Dahlgaard, and E. Holm, 1994: Sediment mixing and burial of the 239 , ${ }^{240} \mathrm{Pu}$ pulse from the 1968 Thule, Greenland nuclear weapons accident. J. Environ. Radioactivity, 25, 135-159.

and and K. Naes, S. Dahle, and D. Matishov, 1995: Sedimentation and mixing rates of radionuclides in Barents Sea sediments off Novaya Zemlya. Deep-Sea Res. II, 42(6), 1471-1493.

Smith, W. O., Ed., 1990: Polar oceanography. Part B, Chemistry, Biology, and Geology, Academic Press, San Diego, CA.

Soyfer, V. N., 1995: Radioecological studies of radioactive contaminants in Ussury Bay, Sea of Japan. Ocean Pollution in the Arctic North and the Russian Far East: Proc. Ocean Pollution Session, Bridges of Science Between North America and the Russian Far East Conf., Vladivostok, Russia, American Association for the Advancement of Science, 66-82.

Straume, T., T. Chinnie Kwan, L. Goldstein, and R. Dobson, 1988: Radiolethal and genetic vulnerabilities of germ cells in the female mammal: effects of tritium and other radiations compared. Third Japan-U.S. Workshop of Tritium Radiobiology and Ilealth Physics, Kyoto, Japan, November, 1988.

Templeton, W. L., R. E. Nakatani, and E. E. Held, 1971: Radiation effects. Radioactivity in the Marine Environment, National Academy of Sciences, Washington, DC, 223-2391. 
Thomas, P. A., 1994: Dosimetry of ${ }^{210}$ Po in humans, caribou, and wolves in northern Canada. Health Phys., $66,678-690$.

J. W. Sheard, and S. Swanson, 1994: Transfer of ${ }^{210} \mathrm{Po}$ and ${ }^{210} \mathrm{~Pb}$ through the lichen-caribou-wolf food chain of northern Canada. Health Phys., 66, 666-677.

Trabalka, J. R., and C. P. Allen, 1977: Aspects of fitness of a mosquitofish Gambusia affinis population exposed to chronic low-level environmental radiation. Radiat Res., 70, 198-211.

Trapeznikov, A. V., A. A. Aarkrog, N. V. Kulikov, S. P. Nielsen, V. N. Pozplotina, G. Polikarpov, V. N. Trapenznikova, M. Ya. Chebotina, V. Chukanov, and P. Yushkov, 1993: Radioactive contamination of the Ob River system from the nuclear enterprise, "Mayak," in the Urals. Proc. Conf. of Environmental Radioactivity in the Arctic and Antarctic, Kirkenes, Norway.

A. Aarkrog, V. Pozolotina, S. P. Nielsen, G. Polikarpov, I. Molchanova, E. Karavaeva, P. Yushkov, V. Trapeznikova, and N. Kulikov, 1994: Radioactive pollution of the Ob river system from Urals nuclear enterprise "Mayak". J. Environ. Radioactivity, 25, 85-98.

United Nations Scientific Committee on the Effects of Atomic Radiation, 1977: Sources and effects of ionizing radiation. UNSCEAR Pub. No. E-77.I.V.1. [United Nations Publications, New York, NY.

1982: UNSCEAR 1982 Report to the General Assembly with Scientific Annexes, United Nations Publications, New York, NY.

1988: Sources, effects and risks of ionizing radiation. UNSCEAR 1992 Report to the General Assembly with Scientific Annexes. United Nations Publications, New York, NY.

1992: UNSCEAR 1992 Report to the General Assembly with Scientific Annexes. United Nations Publications, New York, NY.

1993: UNSCLAR 1993 Report to the General Assembly with Scientific Annexes. United Nations Publications, New York, NY.

1994: UNSCEAR 1994 Report to the General Assembly with Scientific Annexes. United Nations Publications, New York, NY.

1996: UNSCEAR 1996 Report to the General Assembly with Scientific Annexes: Effects of Radiation on the Environment. United Nations Publications, New York, NY.

Usher, P. J., M. Baikie, M. Demmer, D. Nakashima, M. G. Stevenson, and M. Stiles, 1995: Communicating About Contaminants in Country Food: The Experience in Aboriginal Communities.

Vakulovsky, S. M., I. I. Kryshev, A. I. Nikitin, Y. V. Savitsky, S. V. Malyshev, and E. G. Tertyshnik, 1995: Radioactive contamination of the Yenisei river. J. Environ. Radioactivity, 29, 225-236.

Vanderploeg, H. A., D. C. Parzyck, W. H. Wilcox, J. R. Kercher, and S. V. Kaye, 1975: Bioaccumulation factors for radionuclides in freshwater biota. ORNL Rep. ORNL-5002, Oak Ridge National Laboratory, Oak Ridge, TN. 
Volchok, H. L., V. T. Bowen, T. R. Folsom, W. S. Broecker, E. A. Schuert, and G. S. Bien, 1971: Oceanic distributions of radionuclides from nuclear explosions. Radioactivity in the Marine Environment: a Panel on Radioactivity in the Marine Environment of the Committee on Oceanography, Washington, DC, National Research Council.

Welander, A. D., L. R. Donaldson, R. F. Foster, K. Bonham, and A. H. Seymour, 1948: The effects of roentgen rays on the embryos and larvae of the Chinook salmon. Growth, 12, 203-242.

1954: Some effects of $x$-irradiation of different embryonic stages of the trout (Salmo gairdnerii). Growth, 18, 227-255.

Wilimovsky, N. J., and J. N. Wolfe, 1966: Environment of the Cape Thompson region. Alaska U.S. Atomic Energy Commission, Division of Technical Information, Oak Ridge, TN.

Woodhead, D. S., 1977: The effects of chronic irradiation on the breeding performance of the guppy, Poecilia reticulata (Osteichthyes: Teleostei). Internat. J. Radiat. Biol., 32, 1-22. 1984: Contamination due to radioactive materials. Part 3, Marine Ecol., V, 1111-1287.

and Barker, C. J., and Rackham, B. D., 1983: The effects of chronic gamma radiation on experimental fish populations: A preliminary account. Biological Effects of Low-level Radiation, International Atomic Energy Agency, Vienna, Austria, 646-648.

Yablokov, A. V., V. K. Karasev, V. M. Rumyantsev, M. Y. Kokeyev, O. I. Petrov, V. N. Lystsov, A. F. Yemelyanenkov, and P. M. Rubtsov, 1993: Facts and Problems Related to Radioactive Waste Disposal in Seas Adjacent to the Territory of the Russian Federation. Office of the President of the Russian Federation, Moscow, Russia.

Yefimov, E. I., 1994: Radionuclides composition, characteristics of shielding barriers, and analyses of weak points of the dumped reactors of submarine N 601. State Scientific Center of the Russian Federation Rep., Institute of Physics and Power Engineering, Obninsk, Russia.

Yiou, F., G., M. Raisbeck, Z. Q. Zhou, L. R. Kilius, and P. J. Kershaw, 1995: Improved estimates of oceanic discharges of ${ }^{129} \mathrm{I}$ from Sellafield and La Hague. Proc. Second International Conference on Environment Radioactivity in the Arctic, Oslo, Norway, Scientific Committee of the Environmental Radioactivity in the Arctic, 113-116.

Zenkevitch, L., 1963: Biology of the Seas of the USSR. George Allen \& Unwin Ltd., London, England. 